\title{
'Of Red War and Little Else': \\ European Responses to Indigenous Violence in the Tasman World, c.1769-1850s
}

Samuel Gordon Gardiner Ritchie

\begin{abstract}
A thesis
submitted to the Victoria University of Wellington in fulfilment of the requirements for the degree of Doctor of Philosophy in History
\end{abstract}


For my Michelle and our Matilda Dylan arohanui, arohamai 


\begin{abstract}
Europeans responded to indigenous internecine violence in a variety of ways in the Tasman world from first contact to the middle of the nineteenth century. Whereas extant historiography has previously addressed European responses to Māori and Aboriginal violence in geographic and temporal isolation, a comparison spanning time and space augments knowledge of these responses. Violence was not the only aspect of indigenous societies Europeans responded to, nor was indigenous violence the only justification for colonisation. However an investigation of the ways in which Europeans represented and responded to indigenous violence enables a better understanding of the processes of the colonisation of the Tasman world.
\end{abstract}

Indigenous internecine violence included cannibalism, infanticide, intergender violence, and inter-tribal warfare. Through a wide variety of European observations of this violence, this thesis identifies an initial conceptualisation of both New Zealand Māori and Aboriginal peoples of Australia as violent, cannibal 'savages'. This conceptualisation was used to justify both colonisation and the related evangelical and colonial administrative attempts to suppress indigenous violence, as internecine violence was deemed 'uncivilised', unchristian, and unacceptable. Europeans attempted to suppress indigenous violence as it was seen both as an impediment to colonisation and, relatedly, as an inhibitor to the 'redemption' of indigenous peoples. While indigenous violence was seen as a barrier to colonisation, however, it was also simultaneously used to promote colonisation. Thus the attempted suppression of indigenous violence developed into the European mobilisation and utilisation of intra-Māori and intra-Aboriginal violence in the promotion of colonisation.

The development of European responses to indigenous internecine violence - from conceptualisations, through attempted suppression, to utilisation - is here examined in a Tasman-world context, drawing upon the interactions between these varied responses. In tracing this development within a comparative framework, both indigenous agency and a rejection of the historiographically persistent notions of a homogenous (and harmonious) Aboriginal Australia and a homogenous Māori people during this time period are key threads. 


\section{Acknowledgments}

Firstly I must thank my supervisors, Professor James Belich and Professor Richard S. Hill. Without their encouragement, challenges, and advice this thesis would, in all likelihood, have never come to be, certainly not in the manner in which it has. I consider myself extremely privileged to have been supervised by two such excellent historians; however, I take full responsibility for any faults which remain in my work.

Other Stout Research Centre staff and residents, in particular director Professor Lydia Wevers and former administrator Louise Grenside, also provided much-appreciated help and encouragement. I found the Stout a very intellectually stimulating environment in which to work and am grateful for the space made available for me there. Steven Loveridge shared an office with me, and Charlotte Bennett offered much encouragement from the office next door.

I am also grateful to members of the Victoria University of Wellington History Programme, in particular Dr. Adrian Muckle, who offered many useful suggestions during the final stages of drafting.

My whānau, especially my parents, provided much encouragement and support. Knowing I was always welcome at my Whāingaroa tūrangawaewae offered great comfort, and my time there was always rejuvenating. My brother Benjamin, with whom I first explored Perth, and who later hosted me on my second visit to Nyungar country (when we proved Marsden wrong at Margaret River), offered necessary distractions.

To those who hosted me in Melbourne I am grateful: my cousin Megan Higson, whose secret FitzRoy bars and restaurants were a welcome break from the archives; and Rachel Standfield and Jason Groom, whose hospitality, other bars and restaurants, and discussions about history, race, and sport also offered a much-needed escape from reading nineteenth-century handwriting.

The Friday night Magpies kept me laughing. 
Various sources of funding enabled me to finance my study and to travel to Australian archives and conferences: a Victoria University of Wellington PhD Scholarship (2010-2012); a Victoria University of Wellington Postgraduate Students' Association Travel Grant (2010); four Victoria University of Wellington Faculty of Humanities and Social Sciences Research Grants to visit Perth (2010), Sydney (2010), and Melbourne (2011 and 2012); and a J.L. Stewart Postgraduate Scholarship (2010).

The librarians and archivists of the Victoria University of Wellington library, the Alexander Turnbull Library, the Hocken Library, the Mitchell Library, the State Library of Victoria, and the Public Records Office of Victoria, provided access to vital sources.

I have many more people to thank and many more anecdotes about the passage of this thesis from an idea into a reality to share, but, like F.E. Maning before me, I 'must say very little more lest [t]he[y] get a peep at the ass's ears under the philosopher's cloak'. ${ }^{1}$ Most importantly, however, I am evergrateful to my wife Michelle, who held my hand when I was scared and whom I know will catch me should I fall. I love you.

Sam Ritchie

October 2012

\footnotetext{
1 Maning, 8 January 1883, cited in T.M. Hocken, 'Introduction', in F.E. Maning, Old New Zealand: a Tale of the Good Old Times [1863], Auckland:1930, p.xxvii
} 


\section{Contents}

Abstract $\quad$ iv

Acknowledgments $\quad$ V

List of Abbreviations viii

Introduction $\quad 1$

Section I: Violent, Cannibal 'Savages'

Chapter One - 'Confirmed cannibals': the Conceptualisation of Aboriginal Violence 22

Chapter Two - '[A] most warlike people': the Conceptualisation of Māori Violence $\quad 62$

Section II: Bible \& Sword

Chapter Three - '[T]o encircle them in the arms of protection': the Suppression of Aboriginal Violence

Chapter Four - '[S]words and spears into hooks and plough shares': the Suppression of Māori Violence

Section III: Mutual Exploitation

Chapter Five - '[H]orrible instruments of colonial law': the Port Phillip Native Police and the Utilisation of Aboriginal Violence

Chapter Six - '[W]hose aid saved the colony': Kūpapa, Māori Police, te Ātiawa feud, and the Utilisation of Māori Violence

Conclusion

Select Bibliography 


\section{List of Abbreviations}

$\begin{array}{ll}\text { ADB } & \text { Australian Dictionary of Biography } \\ \text { AH } & \text { Aboriginal History } \\ \text { AJHR } & \text { Appendices to the Journals of the House of Representatives } \\ \text { ATL } & \text { Alexander Turnbull Library } \\ \text { BPP } & \text { British Parliamentary Papers (Irish University Press Series), } \\ & \quad \text { Colonies, New Zealand } \\ \text { CMS } & \text { Church Missionary Society } \\ \text { DNZB } & \text { Dictionary of New Zealand Biography } \\ \text { HL } & \text { Hocken Library } \\ \text { HRNZ } & \text { Historical Records of New Zealand } \\ \text { HRV2A } & \text { Historical Records of Victoria, Volume 2A } \\ \text { HRV2B } & \text { Historical Records of Victoria, Volume 2B } \\ \text { JAIGBI } & \text { Journal of the Anthropological Institute of Great Britain and Ireland } \\ \text { JPH } & \text { Journal of Pacific History } \\ J P S & \text { Journal of the Polynesian Society } \\ J R A H S & \text { Journal of the Royal Australian Historical Society } \\ \text { KJV } & \text { King James Version } \\ \text { LMS } & \text { London Missionary Society } \\ \text { NZJH } & \text { New Zealand Journal of History } \\ \text { NZSCSG } & \text { New Zealand Spectator and Cook's Strait Guardian } \\ \text { PROV } & \text { Public Records Office of Victoria } \\ \text { SLV } & \text { State Library of Victoria } \\ \text { VHM } & \text { Victorian Historical Magazine } \\ \text { WMS } & \text { Wesleyan Missionary Society }\end{array}$




\section{Introduction}

Arriving in Australia, Europeans encountered a strange new land. A land of trees on which the grey leaves stayed year-round and yet from which the bark shed regularly; of seemingly endless sky-blue sky. A land where temperatures were hot enough to make the mercury burst right out of the top of the thermometer, ${ }^{1}$ hot enough to cause expanses of explosive eucalyptus to sporadically burst into flames. Europeans arriving in Aotearoa/New Zealand also encountered an unfamiliar landscape. Islands of rugged coastlines peppered with harbours; interiors of craggy volcanic mountains and dense subtropical bush. Amid unfamiliar landscapes, weather, flora, and fauna, Europeans who travelled to the Antipodes also encountered strange new peoples.

The short-title of this thesis draws upon Elsdon Best, who in his work on Tūhoe admitted: 'I tell of red war and little else'. By way of explanation, the ethnographer asserted that he wrote of Māori violence because 'that is all of their history that has been preserved by the neolithic Maori'. ${ }^{2}$ James Belich notes that both the increased Māori warfare of the 1820s and the nature of history itself led to a prominence of war in the telling of Māori history, which in turn caused an exaggeration of the level of pre- and early-contact Māori violence. ${ }^{3}$ Best's assertion is borrowed here then, not because it indicates the intensity of indigenous internecine violence, though an indigenous exaggeration of violence is an important part of the story of indigenous agency in European responses to Māori and Aboriginal violence. Rather, this is a history 'of red war and little else' because indigenous violence so fascinated

\footnotetext{
${ }^{1}$ As happened to Captain Charles Sturt while exploring the interior in 1845; Ernest Favenc, The History of Australian Exploration, from 1788 to 1888 [1888], Sydney:1983, pp.148-149

2 Elsdon Best, Tuhoe: Children of the Mist [1925], second edition Wellington:1972, p.119

3 James Belich, Making Peoples: a History of the New Zealanders, from Polynesian Settlement to the End of the Nineteenth Century, Auckland:1996, pp.75-76
} 
Europeans that violence dominated their conceptualisations of, and responses to, indigenous peoples of the Tasman world from first contact to the middle of the nineteenth century.

While violence was not the only aspect of indigenous cultures which Europeans reacted to, it was perhaps the most discussed and most often responded to feature of Māori and Aboriginal societies. Thus the short-title of this thesis also invokes Belich's useful 'septifocal set of distorting spectacles', through which Europeans perceived Māori and other non-European peoples. Belich argues that 'Europeans saw Pacific peoples through various lenses of preconception, and understanding racial optics is important for the study of contact'. These seven coloured lenses were clear, grey, white, black, brown, green, and red. The clear lens showed a relatively objective view of Māori; however it was never perfectly clear, just sometimes less smudged than others. Grey perceived Māori as a dying race. White saw Māori as the most superior indigenous people on the European's racial hierarchy - 'civilisable', Christianisable, and Europeanisable 'savages'. The black lens was the opposite: it perceived an irredeemable 'savage'. Brown saw inferior, subordinate Māori. Green envisioned the 'noble savage', in harmony with their environment. The red lens, the lens of significance for this study, conceptualised violent, warlike 'savages'. 'These stereotypes', Belich suggests, 'permeate the European evidence', although not to the extent that they cannot be accounted for in interpreting European perceptions of indigenous peoples. ${ }^{4}$

The primary materials upon which this thesis draws include the writings of: James Cook, Joseph Banks, and other early explorers; evangelical missionaries who operated in the Tasman world; protectors of Aborigines of both the

\footnotetext{
4 ibid., passim, esp. pp.20-22 \& 125-126; James Belich, 'Myth, Race, and Identity in New Zealand', New Zealand Journal of History (NZH), 31:1, 1997, pp.9-22; James Belich, 'Race and New Zealand: Some Social History of Ideas', Macmillan Brown Lectures:1994
} 
New Zealand Protectorate and the Port Phillip Protectorate; and colonial administrators involved in the employment of Native Police - both in New Zealand and the Port Phillip District of New South Wales - and in the Northern War, and te Ātiawa feud in New Zealand. These sources are necessarily selective, but the selections made represent a fair cross-section of explorers, evangelicals, and colonial officials of the period. Furthermore, these sources are problematic in that they are almost wholly written by European men with specific objectives in mind. The very nature of the roles of these various agents of colonisation meant that they wrote down much of what they thought and experienced. They thus created a vast archive of European responses to indigenous violence which can be effectively utilised so long as these limitations are taken into account. The reactions to indigenous violence detailed by these commentators - available in their journals, correspondence, and published works - are here used to access and explore European conceptualisations of and responses to indigenous violence.

Within this thesis European responses to violence among Māori and Aboriginal peoples of New South Wales are examined, tracing the development from initial conceptualisations, through attempts at suppression, ${ }^{5}$ to the utilisation of indigenous violence, from 1769 to the 1850s. The ways in which Europeans responded to indigenous internecine violence are here investigated in order to better understand the processes of colonisation in the Tasman world. An indigenous violence-focused interpretation aids a better understanding of colonisation because perceptions of and reactions to violence dominated the European actions which shaped colonisation.

\footnotetext{
5 'Suppression' is here applied as a broad shorthand for various means of attempting to intervene in indigenous violence, from discouragement, through coercion, to counter-violence. Similarly, 'violence' is also broadly defined.
} 
In this thesis it is argued that European attitudes towards indigenous peoples of the Tasman world were largely shaped by the belief that they were violent 'savages'. For European colonisers, internecine violence justified labelling Māori and the Aboriginal peoples of Australia 'savages', which in turn was used to justify colonisation. At the heart of this study is the paradox that while many European commentators, including some colonial officials working with indigenous peoples, wrote of heterogeneous, autonomous groups of Māori and Aborigines, colonial administrators at Auckland, Melbourne, Sydney, and London often perceived a homogeneous Māori and a homogeneous Aboriginal peoples of Australia, and issued colonial policies shaped by these beliefs - policies which at times exacerbated the very violence they sought to suppress. At the same time, the Crown also willingly utilised the heterogeneous nature of the indigenous peoples of the Tasman world, forming alliances with some groups to make use of their traditional violence to promote colonisation.

The paradox of simultaneously utilising indigenous violence while simultaneously seeking to suppress it has rarely been acknowledged in the Tasman world. Yet Europeans have long utilised indigenous violence in the pursuit of empire, particularly to suppress indigenous resistance. Whereas extant historiography has previously addressed European responses to Māori and Aboriginal violence in geographic and temporal isolation, the contribution of this thesis lies in conducting comparative case studies in order to interrogate European attitudes to and relations with the indigenous peoples of the Tasman world between 1769 and the 1850s. By investigating the complicated European portrayal of Māori and Aboriginal peoples of Australia as homogeneous yet also internally violent, this study aids understanding of the Crown colonial policy of divide and rule, then in operation across the British Empire. This in turn further reveals the complexities of colonial governance 
and authority in the Tasman world. Meanwhile, analysis of indigenous agency within this strategy of divide and rule reveals new understandings of how individuals and groups, Aboriginal and Māori, sought to be (and succeeded in being) an integral part of the colonisation of the Tasman world.

While there is much historiography on race in Australia and the Pacific, and many other aspects of European-indigenous contact have been the focus of recent studies, rather than simply repeating the chosen frameworks of others, this thesis seeks to stand in conversation with the work of previous historians by referencing their influence while offering a fresh perspective on the ideas and actions behind the colonisation of the Tasman world. For example, whereas Vanessa Smith has recently investigated inter-racial friendship in early Pacific encounters, and Damon Salesa has examined 'racial crossings' 'different races associating, liaising, reproducing, marrying or consorting' in the Victorian British Empire, the focus of this work is European responses to internecine violence. ${ }^{6}$ Nevertheless, this work benefits from the extensive research undertaken on the racialisation of indigenous peoples in Australia and the Pacific.

Shino Konishi has recently examined how Aboriginal men, through their encounters with eighteenth-century explorers, were brought into the ambit of the Enlightenment world. The investigation of European responses to Aboriginal violence offered here reinforces Konishi's findings about the categorisation and racialisation of Aboriginal peoples of Australia. The analysis of Cook's and Banks' observations of Aboriginal peoples offered in chapter one, for example, accords with Konishi's assertion that 'many of the explorers' accounts of Aboriginal men were more contradictory and unstable than most

\footnotetext{
${ }^{6}$ Vanessa Smith, Intimate Strangers: Friendship, Exchange and Pacific Encounters, Cambridge:2010; Damon leremia Salesa, Racial Crossings: Race, Intermarriage, and the Victorian British Empire, Oxford:2011, p.1
} 
histories suggest'. Furthermore, this thesis also coheres with Konishi's warning that 'analyses which focus on the development of racial theories risk ignoring indigenous agency and presenting Aboriginal people as little more than ciphers in the development of European discourses of the other' - hence the incorporation of indigenous agency throughout this work. ${ }^{7}$

Bernard Smith's pioneering work on European imaginings and perceptions of Pacific peoples, particularly his argument for a cognitive theory of perception, has been very influential in the framing of this thesis, as has Anne Salmond's thought-provoking discussions of first contact between Europeans and Pacific peoples, particularly Māori and Tahitians. Salmond's successful respect for both the European and indigenous perspectives of contact has set a precedent for Pacific historians which cannot be ignored. ${ }^{8}$ Like Salmond, Nicholas Thomas, too, has recently written an in-depth study of Cook's Pacific voyages. Thomas argues that Cook was not an agent of imperialism; he believes seeing Cook as such is 'judging him according to how we judge what happened afterwards'. ${ }^{9}$ The analysis of Cook's Pacific voyages offered here opposes Thomas' interpretation, instead seeing the writings of Cook and his crews as conscious precursors to the colonisation of the Tasman world. Cook was, after all, primarily searching for an unknown continent because of its assumed great wealth, and was instructed to report on the economic potential of any lands and peoples he encountered.

\footnotetext{
7 Shino Konishi, The Aboriginal Male in the Enlightenment World, London:2012, pp.5-6

8 Bernard Smith, European Vision and the South Pacific [1960], second edition Sydney:1989; Bernard Smith, Imagining the Pacific in the Wake of the Cook Voyages, Melbourne:1992; Anne Salmond, Two Worlds: First Meetings Between Maori and Europeans, 1642-1772, Auckland:1991; Anne Salmond, Between Worlds: Early Exchanges Between Maori and Europeans 1773-1815, Auckland:1997; Anne Salmond, The Trial of the Cannibal Dog: Captain Cook in the South Seas, London:2003; Anne Salmond, Aphrodite's Island: the European Discovery of Tahiti, Auckland:2009; Smith has been followed by Rod Edmond, Representing the South Pacific: Colonial Discourse from Cook to Gauguin, Cambridge:1997

9 Nicholas Thomas, Discoveries: the Voyages of Captain Cook, London:2003, p.xxxiii
} 
The groundbreaking works of Henry Reynolds and Judith Binney, on Aboriginal and Māori agency respectively, have also influenced the development of this research, and the findings offered here reinforce their insistence on the importance of indigenous agency within racial constructions in the Tasman world. In particular, Binney's demand that 'historians must ... become consciously "bihistorical"' has fuelled the attempt to incorporate both indigenous and European influences on and perspectives of the events analysed in this work. ${ }^{10}$

The complicated circulation of colonial writings on, and policies regarding, indigenous peoples examined within this thesis sits within Tony Ballantyne's recent reconceptualising of empire as made up of webs of networks and exchanges. Ballantyne writes: '[t]he inherently relational nature of the empire is ... underlined by the image of the web'. While 'so much writing on imperial/colonial history reduces the empire to a series of metropole-periphery binaries', he argues, 'the web reinforces the multiple positions that any given colony, city, community, or archive might occupy'.${ }^{11}$ Ballantyne's redefining of the centre/periphery imagining of empire - along with recent colonial histories which take up similar positions - fuels the understanding in this work of the actors and ideas of the colonisation of the Tasman world as part of a transnational circulation of knowledge, people, and procedures. ${ }^{12}$

\footnotetext{
10 Henry Reynolds, The Other Side of the Frontier: Aboriginal Resistance to the European Invasion of Australia [1981], Melbourne:1982; Judith Binney, Encircled Lands: Te Urewera, 1820-1921, Wellington:2009, esp. p.viii; Judith Binney, Redemption Songs: a Life of Te Kooti Arikirangi Te Turuki, Auckland:1995

${ }^{11}$ Tony Ballantyne, 'Race and the Webs of Empire: Aryanism from India to the Pacific', Journal of Colonialism and Colonial History, 2:3, 2001, np

12 Tony Ballantyne, Webs of Empire: Locating New Zealand's Colonial Past, Wellington:2012; Anna Johnston, The Paper War: Morality, Print Culture, and Power in Colonial New South Wales, Perth:2011
} 
This thesis is organised to allow comparison of European responses to indigenous violence. The key framework for this work is the Tasman world. Rachel Standfield's work comparing the development of racial thought in Australia and New Zealand has helped to shape this chosen structure. ${ }^{13}$ The investigation of European responses to indigenous violence offered here reinforces Standfield's analysis of the different racial ideas that Europeans applied to indigenous peoples of the Tasman world, which in turn underpinned the divergent colonial histories of Australia and New Zealand. Whereas Standfield's focus concerns land, however - specifically European perceptions that Aboriginal peoples were 'wanderers' who did not improve or own their land, as opposed to the view that Māori were 'warriors', who did improve and thus own their land, and were willing to defend it - the focus of this work is specifically internecine violence.

During the late-eighteenth and early-nineteenth centuries the Tasman Sea was not a barrier, but a bridge which linked New South Wales and New Zealand - the Tasman world. ${ }^{14}$ In contrast to other geographical impediments, such as initially the Blue Mountains and later the Southern Alps, the Tasman Sea provided a relatively easy passage for the transfer of people, ideas, and goods. This important historical locale consists of the colonies of New South Wales $^{15}$ (including the Port Phillip District, which became the colony of Vic-

\footnotetext{
13 Rachel Standfield, 'Warriors and Wanderers: Making Race in the Tasman World, 1769-1840', PhD thesis, University of Otago:2008; Rachel Standfield, Race and Identity in the Tasman World, 1769-1840, London:2012; Rachel Standfield, 'Violence and the Intimacy of Imperial Ethnography: the Endeavour in the Pacific', in Tony Ballantyne and Antoinette Burton (eds.), Moving Subjects: Gender, Mobility, and Intimacy in an Age of Global Empire, Chicago:2009, pp.31-48

14 Belich, Making Peoples, p.134; James Belich, Replenishing the Earth: the Settler Revolution and the Rise of the Anglo-World, 1783-1939, Oxford:2009, p.183

15 'New South Wales' denoted the entire eastern half of Australia from Cook's 1770 encounter until 1826, when the island of Van Diemen's Land became a separate colony, which was renamed Tasmania in 1856. In 1836 the colony of South Australia was established, followed by Victoria in
} 
toria in 1851) and New Zealand, from first contact at least until Victoria's separation, and arguably to Australian Federation in $1901 .^{16}$

The Tasman world is an important historical notion which has been often disregarded in the writing of many nation-based narratives; more recently it has also been historiographically misrepresented. ${ }^{17}$ The nation-based approach which has dominated the writing of New Zealand and Australian history is not a fair representation of these countries' post-contact histories. Belich quite rightly argues for the existence of the Tasman world in his discussion of late-eighteenth- and early-nineteenth-century sealers in the region as 'part of a joint past historians in both countries seem reluctant to recognise' $^{18}$ To suggest that the explorers, evangelicals, ${ }^{19}$ and colonial officials whose observations make up the perceptions examined in this thesis fit with Belich's assertion that whalers, sailors, sealers, 'and other wandering workers ... did not see Australia and New Zealand as markedly separate places'

1851 and Queensland in 1859. For geographical reasons, and in keeping with rejecting the homogenisation of the Australian colonies, South Australia, Queensland, and Tasmania are not examined in any depth in this thesis, though they could arguably be included in the Tasman world.

16 James Belich, Paradise Reforged: a History of the New Zealanders, from the 1880s to the Year 2000, Auckland:2001, pp.30-31, 46-47, 46n \& 51-52; Keith Sinclair, 'Why New Zealanders are not Australians: New Zealand and the Australian Federal Movement, 1881-1901', in Keith Sinclair (ed.), Tasman Relations: New Zealand and Australia, 1788-1988, Auckland:1987, pp.90-103; cf. Philippa Mein Smith, who argues '[i]n the twenty-first century the Tasman world is more integrated that at any time in the brief 200 years of its history'; Philippa Mein Smith, 'The Tasman World', in Giselle Byrnes (ed.), The New Oxford History of New Zealand, Melbourne:2009, p.318

17 To include Darwin, only 600 kilometres from South East Asia, or Perth, separated from Melbourne by over 2500 kilometres including the Nullarbor Plain, in the Tasman world, as Mein Smith and Peter Hempenstall have recently done, is spatially naïve and ignores the regional differences of the Australian colonies (and later states and territories); Philippa Mein Smith, Peter Hempenstall, and Shaun Goldfinch, Remaking the Tasman World, Christchurch:2008, passim; Mein Smith, 'Tasman World', pp.297-319; Philippa Mein Smith and Peter Hempenstall, 'Australia and New Zealand: Turning Shared Pasts into a Shared History', History Compass, 1:1, 2003, pp.1-10; cf. Kate Hunter, '[Review of] Remaking the Tasman World', NZJH, 43:2, 2009, pp.216-217

18 Belich, Making Peoples, p.132

19 In 1793 the Evangelical Magazine was established to cater to Protestants of any denomination who were devoted to spreading the gospel and it is in this sense the term 'evangelical' is here employed - to denote the inter-denominational Protestant philanthropic movement which began in Britain in the 1730s; D.W. Bebbington, Evangelicalism in Modern Britain: a History from the 1730s to the 1980s, London:1989, pp.1-2; S.G.G. Ritchie, “"TT]he sound of the bell amidst the wilds": Evangelical Perceptions of Northern Aotearoa/New Zealand Māori and the Aboriginal Peoples of Port Phillip, Australia, c.1820s-1840s', MA thesis, Victoria University of Wellington:2009, pp.18-19 
would be to ignore the opposing positions on the Europeans' hierarchy of races assigned to Māori and the Aboriginal peoples of Australia. ${ }^{20}$ Nevertheless, while it did not cause the conflation of Māori and the Aboriginal peoples of New South Wales, the Tasman world was a more important geographic space than were New Zealand and New South Wales as disconnected locales.

The 'middle ground', as the Tasman Sea was known to whalers in the earlynineteenth century, ${ }^{21}$ is 2000 kilometres across, whereas Sydney is 25,750 kilometres by ship from London. ${ }^{22}$ The First Fleet took over 250 days to sail from Portsmouth to Port Jackson. In the early-nineteenth century sailing from Britain to the Tasman world took 200 days. By contrast, one Church Missionary Society (CMS) missionary told a British House of Commons Select Committee in 1836 that the average length of passage from New Zealand to New South Wales was 'from ten days to a fortnight'. ${ }^{23}$ Furthermore, when a Wesleyan Missionary Society (WMS) missionary sailed from Hobart Town to Melbourne in mid-1838, the voyage took twenty-two days. ${ }^{24}$ While the majority of this particular journey was spent in violent storms in the Bass Strait, perhaps an exceptional (though not uncommon) circumstance, the point is that the Bay of Islands was sometimes closer to mainland southeast Australia than was Hobart Town.

\footnotetext{
20 Belich, Making Peoples, p.131

21 J.S. Polack, New Zealand: Being a Narrative of Travels and Adventures During a Residence in that Country Between the Years 1831 and 1837 [1838], 2 vols., Christchurch:1974, i:p.251 \& ii:pp.205 \& 414

${ }^{22}$ Whalers here inadvertently anticipated Richard White's description of Amerindian-European contact in the Great Lakes region of North America as a 'middle ground' of accommodation on both sides. White's thesis has since been employed in other contact situations, notably recently by Vincent O'Malley in the New Zealand context; Richard White, The Middle Ground: Indians, Empires, and Republics in the Great Lakes Region, 1650-1815, Cambridge:1991; Vincent O'Malley, The Meeting Place: Māori and Pākehā Encounters, 1642-1840, Auckland:2012

${ }^{23}$ Report from the Select Committee on Aborigines (British Settlements); Together with the Minutes of Evidence, Appendix and Index, 2 vols., London:1836-1837, i:p.194

24 Tuckfield to WMS secs., 12 August 1838, Michael Cannon (ed.), Historical Records of Victoria, Volume 2A: the Aborigines of Port Phillip, 1835-1839 (HRV2A), Melbourne:1982, p.105
} 
For twenty-five years the Blue Mountains kept the European settlement of New South Wales confined to Port Jackson and the Cumberland Plains. During this time the Reverend Samuel Marsden had numerous Māori visiting him at Parramatta from across the Tasman Sea and had begun laying the foundations of a mission to Māori, which was to be run from Parramatta from its establishment in 1814 at least until the arrival of the Reverend Henry Williams in the Bay of Islands in $1823 .{ }^{25}$

For Westland, which lies on the Tasman Sea coast of Te Wai Pounamu (the South Island), the Southern Alps also proved a far greater geographical barrier than did the Tasman Sea during the district's 1860s gold-rush. The province of Canterbury, of which Westland was initially a part, spent vast amounts of money attempting to conquer the geographical separation of its main city Christchurch from its gold-rich west coast. This economic endeavour largely failed, and despite the inadequate harbour at Hokitika the colony of Victoria supplied about fifty-four per cent of imports to Westland during the rush, which led to Hokitika being described as a 'trans-Tasman suburb of Melbourne' ${ }^{26}$

To study New Zealand and New South Wales as two distinctly separate places in the late-eighteenth and early-nineteenth centuries is to overlook the movement of people, ideas, and goods between them, and is thus to apply a contemporary perception of New Zealand and southeast Australia which at that time did not exist. ${ }^{27}$ Despite the regional differences of the Australian states and territories, Australian Federation and the nation-based histories

\footnotetext{
25 Rachel Standfield, 'The Parramatta Maori Seminary and the Education of Indigenous Peoples in Early Colonial New South Wales', History of Education Review, 41:2, 2012, pp.119-128; Ritchie, 'sound of the bell amidst the wilds', pp.3-4 \& 31-33

26 Belich, Making Peoples, p.348; Belich, Replenishing the Earth, pp.421-422

27 Standfield, 'Warriors and Wanderers', pp.11-19
} 
which subsequently arose, overrode the importance of the Tasman world in the nineteenth century and projected the idea of a homogenous Australia and a separate New Zealand back into writings on the nineteenth century.

In 1788 there were an estimated 300,000 indigenous people, divided into over 500 language groups, living in Australia. ${ }^{28}$ While it is extremely important to acknowledge the diversity of the Aboriginal peoples of Australia, European commentators often homogenised Aboriginal Australians, thus the frequent necessary discussion of 'Aborigines' within this thesis; use of the term 'Aboriginal peoples' ('Aborigines' for short) is a conscious attempt to acknowledge this problem of assumed homogeneity and assigned panAboriginality. The Encyclopaedia of Aboriginal Australia has been used throughout this thesis to identify country and to spell the names of Aboriginal language groups consistently. ${ }^{29}$ Gary Presland's First People has also been useful in the identification of the country of the language groups of Port Phillip. ${ }^{30}$

While culturally and linguistically more uniform than Aborigines, Māori too were homogenised by European commentators. In works which concern pre-twentieth-century Māori, this assigned Māori homogeneity at the expense of iwi (tribe), hapū (sub-tribe), and even whānau (family) individual-

\footnotetext{
28 Richard Broome, Aboriginal Australians: Black Responses to White Dominance, 1788-1994 [1982], second edition Sydney:1994, p.11; Bob Reece, 'Inventing Aborigines', Aboriginal History [AH], 11:1, 1987, pp.14-23; Lynette Russell, Savage Imaginings: Historical and Contemporary Constructions of Australian Aboriginalities, Melbourne:2001, passim

${ }^{29}$ David Horton (ed.), The Encyclopaedia of Aboriginal Australia: Aboriginal and Torres Strait Islander History, Society and Culture, 2 vols., Canberra:1994

${ }^{30}$ Gary Presland, First People: the Eastern Kulin of Melbourne, Port Phillip \& Central Victoria, Melbourne:2010
} 
ity needs to be acknowledged. ${ }^{31}$ This homogenisation was often drawn from conversations with one or a few Māori individuals then extrapolated to make sweeping statements about all Māori - as when Marsden reported on his first visit to New Zealand that '[t]he New Zealanders are all cannibals.' ${ }^{2}$ Joel Samuel Polack, a London-born Jew of Dutch heritage who arrived in New Zealand in 1831, acknowledged he was generalising when he wrote of the Manners and Customs of the New Zealanders. He believed that although 'some differences do exist, in a greater and less degree' among Māori, these differences were akin to those 'as may be remarked between the habitants of separate counties in Great Britain, or villagers seperated by mountainous districts'. Polack asserted that 'strict observance of the national institutions' was enforced by Māori rangatira (chiefs) and tohunga (priests). ${ }^{33}$ Most lateeighteenth- and early-nineteenth-century European commentators wrote of a homogenous Māori, thus the necessary reference to a uniform Māori herein.

Use of the term 'internecine' is, therefore, somewhat problematic. Describing inter-iwi/language group violence as 'internecine' seemingly fuels the historiographically pervasive yet misleading portrait of a homogenous Māori and a homogenous Aboriginal Australia. As these peoples were perceived to be homogenous and thus their violence to be internecine, however, the word 'internecine' is persisted with, while at the same time the rejection of both a homogenous pre-twentieth-century Māori and a homogenous pretwentieth-century Aboriginal Australia is a thread which runs through this thesis.

\footnotetext{
31 Angela Ballara, Iwi: the Dynamics of Māori Tribal Organisation from c.1769 to c.1945, Wellington:1998, passim; Claudia Orange, The Treaty of Waitangi, Wellington:1987, pp.6-7

32 Samuel Marsden, 'First New Zealand Journal', J.R. Elder (ed.), The Letters and Journals of Samuel Marsden, 1765-1838, Dunedin:1932, p.129

33 J.S. Polack, Manners and Customs of the New Zealanders [1840], 2 vols., Christchurch:1976, ii:p.90
} 
Marilyn Lake suggests that '[t]rans-national history should not be confused with comparative history'. 'The latter has opened up questions about national distinctiveness', she continues, 'and there has been much fruitful work comparing different nation- or colony-based experiences - but the effect of comparative history is to present parallel histories that reinforce the dominance of national paradigms in historical explanation'. ${ }^{34}$ Responding to Lake, the intent in this thesis is to be comparative and to discuss transnational people and ideas while not presenting parallel histories. Although New Zealand and New South Wales experienced very different encounter and settlement histories, because these were located within the geographical locale of the Tasman world and because both were colonised by Britain, the two histories influenced one another. Many Europeans, particularly colonial officials and missionaries, operated in a transnational context, moving between and beyond New South Wales, New Zealand, and Britain. Furthermore, European perceptions, particularly comparisons, of the indigenous peoples of the Tasman world and the design of an Aboriginal Protectorate were certainly transnational ideas, and these are here compared in New South Wales and New Zealand without confusing transnational history with comparative history; the two do not have to be mutually exclusive.

The first section of this thesis details the conceptualisation of indigenous internecine violence in New Zealand and Australia. Chapter one analyses the conceptualisation of Aboriginal violence - particularly cannibalism but also infanticide, sorcery, revenge killings, and inter-gender violence - through an examination of the observations of initial explorers and first settlers, and

\footnotetext{
${ }^{34}$ Marilyn Lake, 'White Man's Country: the Trans-National History of a National Project', Australian Historical Studies, 34:122, 2003, pp.348-349
} 
culminating in a discussion of Daisy Bates, the last of the Victorian anthropologists and perhaps the most influential writer on Aboriginal cannibalism. Aboriginal agency in this conceptualisation is also investigated.

Chapter two explores the conceptualisation of Māori violence - particularly cannibalism and inter-iwi warfare - through an examination of early explorers' and missionaries' portrayals of Māori as violent, cannibal 'savages'; Māori agency in this portrayal; and how positive representations of Māori survived this image. Section one therefore addresses why Māori violence was simultaneously admired and reviled by Europeans while Aboriginal violence was not regarded in the same manner - how Māori, a people depicted as violent, cannibal 'savages', could be placed near the top of all indigenous peoples on the Europeans' hierarchy of races, while on the other hand Aboriginal violence was exaggerated and falsely represented in order to justify their assigned place near, if not at, the bottom of all peoples on said hierarchy. These depictions and assigned hierarchical placements were to have an immense influence on the varying histories of the Tasman world during the nineteenth century and beyond, and on their historiography thereafter. In section one of this work initial European contact with Māori and Aboriginal peoples of New South Wales, and explorers' conceptualisations of indigenous violence, are seen as important and influential precursors to British colonisation, as does Daniel Clayton in his discussion of Cook's contact with indigenous peoples at Nootka Sound..$^{35}$

Having established how Europeans conceptualised Māori and Aboriginal violence, the investigation moves to explore how Europeans responded to this indigenous violence. In New Zealand and in the Port Phillip District of

\footnotetext{
${ }^{35}$ Daniel Clayton, 'Captain Cook's Command of Knowledge and Space: Chronicles from Nootka Sound', in Glyndwr Williams (ed.), Captain Cook: Explorations and Reassessments, Woodbridge, Suffolk:2004, p.111; cf. Edmond, pp.12-13
} 
New South Wales both missionaries and philanthropic, Crown-appointed colonial officials working as protectors of Aborigines sought to suppress indigenous violence. These evangelical and colonial administrative efforts were closely linked, both with one another and with their counterparts across the Tasman Sea, and were an integral part of attempts to 'civilise' and Christianise Māori and the Aboriginal peoples of New South Wales. The 'civilisation' and Christianisation of indigenous peoples necessitated the suppression of indigenous violence.

In discussing the philanthropic and evangelical aims of the 'civilisation' and Christianisation of indigenous peoples, it is important to note that these goals did not imply equality with Europeans. For nineteenth-century evangelicals and colonial officials, indigenous peoples were always to remain inferior. Assimilation may have been an eventual goal, but that was almost inconsequential - many believed indigenous peoples would die out in the wake of contact, before assimilation could occur. The aim of philanthropic colonisers was to convert indigenous peoples to rhythms of life which suited Europeans, who sought land, resources, and labour, and wished to obtain these quickly and cheaply. 'Civilisation' and Christianisation assisted exploitation; though that is not to say evangelicals and colonial officials were not sincere in their concern for the plight of indigenous peoples. ${ }^{36}$

Chapter three addresses Protestant missions in Port Phillip, the Port Phillip Aboriginal Protectorate, and the failed efforts of both missionaries and protectors to suppress Aboriginal violence, which their presence in fact often ex-

\footnotetext{
${ }^{36}$ Jean Woolmington, 'The Civilisation/Christianisation Debate and the Australian Aborigines', $A H$, 10:2, 1986, pp.90-98; Christina Twomey, 'Vagrancy, Indolence and Ignorance: Race, Class and the Idea of Civilization in the Era of Aboriginal "Protection", Port Phillip 1835-49', in Tracey Banivanua Mar and Julie Evans (eds.), Writing Colonial Histories: Comparative Perspectives, Melbourne:2002, pp.93-113; Henry Reynolds, 'Aborigines and European Social Hierarchy', AH, 7:2, 1983, pp.124-133; cf. David Philips, 'Evangelicals, Aborigines and "Land Rights": a Critique of Henry Reynolds on the Select Committee on Aborigines', Australian Studies, 17:1, 2002, pp.147-165
} 
acerbated. Chapter four examines missionary mediation during the Musket Wars, the signing of the Treaty of Waitangi, and the New Zealand protectors of aborigines, whose responsibilities included the suppression of inter-iwi violence. Section two therefore explores why Europeans sought to suppress indigenous violence and how they attempted to do so, and assesses to what degree their attempts were successful.

Influenced by the 1836-1837 parliamentary Report of the House of Commons' Select Committee on Aborigines (British Settlements), an Aboriginal Protectorate was established by Governor Sir George Gipps in the Port Phillip District in 1838. The same select committee findings, combined with the perceived early success of the Port Phillip Protectorate, persuaded colonial officials to create a similar Aboriginal Protectorate in New Zealand in $1840 .{ }^{37}$ These protectorates were charged with safeguarding the indigenous peoples of the Tasman world from offences committed by Europeans, and with 'civilising' and Christianising the Aboriginal peoples of Port Phillip and Māori respectively, with a particular emphasis on the prevention of indigenous internecine violence. ${ }^{38}$

\footnotetext{
37 Alan Lester and Fae Dussart have mapped the trajectory of aboriginal protection from the Caribbean to Van Diemen's Land (1824-1825), on to New South Wales (1838) by way of the Cape Colony (1835) and Britain (1836-1837), and on to New Zealand (1840); Alan Lester and Fae Dussart, 'Trajectories of Protection: Protectorates of Aborigines in Early 19th Century Australia and Aotearoa New Zealand', New Zealand Geographer, 64, 2008, pp.205-220; Lester here extrapolates on his earlier work on the transnational nature of humanitarianism and settler responses to humanitarianism, particularly in New South Wales, New Zealand, and the Cape Colony; Alan Lester, 'Colonial Networks, Australian Humanitarianism and the History Wars', Geographical Research, 44:3, 2006, pp.229-241; Alan Lester, 'British Settler Discourse and the Circuits of Empire', History Workshop Journal, 54, 2002, pp.24-48

38 Report from the Select Committee on Aborigines, ii:pp.82-84; Glenelg to Gipps, 31 January 1838, and Grey to assistant protectors, 6 February 1838, Michael Cannon (ed.), Historical Records of Victoria, Volume 2B: Aborigines and Protectors, 1838-1839 (HRV2B), Melbourne:1983, pp.373-378; Hobson to Clarke, 9 April 1841, cited in Peter D. Gibbons, 'The Protectorate of Aborigines, 18401846', MA thesis, Victoria University of Wellington:1963, p.108; Standfield, 'Warriors and Wanderers', pp.199-255
} 
Three of the four initial assistant protectors appointed to the Port Phillip Protectorate were active Wesleyan Methodists. The chief protector was George Augustus Robinson, who had proved his colonial worth through his efforts to remove Aboriginal peoples of Tasmania from the island. In New Zealand the position of chief protector was filled by former-CMS missionary George Clarke, who saw his new role very much as a continuation of his missionary work. Two of Clarke's sons worked as sub-protectors, as did sons of other CMS missionaries. Both the Port Phillip Protectorate and the New Zealand Protectorate were thus evangelical endeavours.

Along with attempts to suppress indigenous violence, colonial officials increasingly sought to utilise Māori and Aboriginal violence, which forms the focus of the final section of this thesis. Chapter five examines the employment of Aborigines as Native Police troopers, recruited to regulate, often violently, contact on the colonial frontier. Chapter six explores Māori employed to fight on the side of the British in the Northern War, Māori police, and the Crown support of Māori who fought to sell land, specifically during te Âtiawa feud, with relation to the utilisation of Māori violence. Section three therefore explores how the Crown utilised indigenous violence for the promotion of colonisation, and examines how successful this utilisation was.

This study primarily concerns conceptualisations of, and responses to, interiwi/language group violence, though there is much work to be done on European perceptions of, and reactions to, intra-iwi/language group violence. As such, infanticide, inter-gender violence, and other manifestations of intragroup violence are not examined in detail, although intra-group and intergroup violence are at times difficult to separate in evangelical and colonial official attempts to suppress indigenous violence. Thus there is some overlap and intra-group violence is considered briefly. 
It is significant that so many leading Tasman world settlers, colonial officials especially, were of army and naval backgrounds. Twenty-five per cent of those whose biographies appear in the Australian Dictionary of Biography relative to the period 1788-1850, for example, served in the army, the navy, or the East India Company. ${ }^{39}$ All the governors of New South Wales and New Zealand during the period of this study had naval or army backgrounds. Moreover, a number of other key sources for this study, such as the Reverend Henry Williams and Assistant Protector Sievwright, came to the Tasman world having served in the British military. Even for those who were not employed in the military, memories of warfare likely shaped many responses to indigenous peoples they encountered. Europe was at war from the French Revolution in 1789 to the conclusion of the Napoleonic Wars in 1815 - a period of warfare preceded by the American War of Independence (1775-1783), and the Seven Years War (1756-1763).

War was on the minds of Europeans as they encountered Māori and Aborigines in the late-eighteenth and early-nineteenth centuries, and overt parallels were sometimes drawn. In writing of a tauā (war party) which paddled 'at least a hundred miles' to East Cape 'to attack a people, who in all probability have never done any act to provoke their resentment', an early visitor to New Zealand observed that this 'shews to what lengths ambition is carried, even among savages, and what difficulties are cheerfully encountered from the desire of plunder and devastation'. 'This truth', he continued, 'had been exemplified in New Zealand at various intervals, no less than in Europe,

\footnotetext{
${ }^{39}$ Gerald Walsh, 'The Military and the Development of the Australia Colonies, 1788-1888', in M. McKernan and M. Browne (eds.), Australia: Two Centuries of War \& Peace, Canberra:1988, p.43; M.F. Christie, Aborigines in Colonial Victoria 1835-86, Sydney:1979, p.29
} 
which has been deluged in blood for the last five-and-twenty years'. The only difference was, he concluded, 'the number and attributes of the respective forces, the principle and motives being exactly the same' ${ }^{40}$ One Port Phillip assistant protector noted that Aboriginal internecine violence caused by the forced exodus from country occasioned by European settlement should not come as a surprise to Europeans 'when it is remembered that two of the most civilized and most [C]hristian nations upon earth - Great Britain and America - have been for years engaged in an angry dispute, respecting the question of territorial right' ${ }^{41}$

The recent history of European warfare was known to indigenous peoples too. Ngāi Tahu rangatira Tuhawaiki reportedly asserted that while Te Rauparaha may be like Napoleon, he himself was the Duke of Wellington. ${ }^{42}$ The Tasman world was first encountered and settled during and in the immediate wake of the Napoleonic Wars and preceding European conflicts, and war experience shaped Europeans' conceptualisations of and responses to newlyencountered indigenous peoples.

Of course, Europeans also conceptualised and responded to other facets of indigenous societies, such as land usage, social structures, religion, hierarchy, and trade. Violence was, however, the aspect of indigenous societies most responded to by Europeans. Within this thesis the European conceptualisation, attempted suppression, and utilisation of indigenous internecine violence in the Tasman world, and the interactions of these three responses, is

\footnotetext{
40 J.L. Nicholas, Narrative of a Voyage to New Zealand [1817], 2 vols., Auckland:1971, i:pp.393395

41 James Dredge, Brief Notices of the Aborigines of New South Wales, Including Port Phillip, in Reference to their Past History and Present Condition, Geelong:1845, p.14

42 O'Malley, pp.93-94; Angela Ballara, Taua: 'Musket Wars', 'Land Wars', or Tikanga? Warfare in Māori Society in the Early Nineteenth Century, Auckland:2003, pp.33-35; S. Percy Smith, Maori Wars of the Nineteenth Century: the Struggle of the Northern against the Southern Tribes prior to the Colonization of New Zealand in 1840, Christchurch:1910, p.15
} 
investigated from first contact through to the middle of the nineteenth century. Building upon recent works on the racialisation of indigenous peoples in Australia and the Pacific, this focus on European responses to indigenous violence allows for an improved understanding of the colonisation of New Zealand and southeast Australia, and of indigenous reactions to contact and settlement. 


\section{Chapter One \\ 'Confirmed cannibals': \\ the Conceptualisation of Aboriginal Violence}

Violence permeated Europeans' initial writings on Aboriginal peoples of Australia. Converse to the image of timid, passive, and pathetic Aborigines who were sadly but surely disappearing, imagined and circulated by twentieth-century commentators until the disruption of the 'Great Australian silence', this chapter demonstrates that Aborigines were often initially envisioned as violent 'savages'. This conceptualisation of Aboriginal violence particularly cannibalism, but also infanticide, sorcery, revenge killings, and inter-gender violence - is here examined to explore the European construction of Aborigines as violent, cannibal 'savages', the reasons behind such a conceptualisation, and the Aboriginal agency involved in this portrayal.

Belief in Aborigines as violent began even before first contact, with an image of Aboriginal peoples of Australia as frightening, monstrous giants. This image was then complicated by confused reports circulated by the crew of the Endeavour, and compounded by a critical representation of Aboriginal gender relations created initially by members of the First Fleet. These brutal representations were then adjusted to include assertions of cannibalism. Thus, as Henry Reynolds observes, '[m]any early settlers probably arrived in Australia with, or soon acquired, a view of savagery compounded of godless anarchy, violence, cannibalism and sexual depravity. ${ }^{1}$

Gananath Obeyesekere's theories about cannibalism, particularly the European 'cannibal complex', are in this chapter applied to Australia to argue that European assertions of Aboriginal cannibalism were misconceived. All

\footnotetext{
1 Henry Reynolds, 'Racial Thought in Early Colonial Australia', Australian Journal of Politics and History, 20:1, 1974, p.51
} 
three categories of evidence offered - European 'witnesses', Aboriginal 'confessions', and European assumptions with no substantiation - are shown to be evidentially highly problematic. The purpose here is not to enquire into whether Aboriginal cannibalism existed or not; rather the reasons European allegations of anthropophagy materialised and prevailed are explored. The European conceptualisation of Aboriginal cannibalism was part of the construction of Aborigines as violent 'savages'.

In this chapter it is argued that Europeans initially envisioned Aboriginal peoples as violent 'savages'. Soon after first settlement accusations of cannibalism were added to this depiction of violent 'savagery'. In analysing this conceptualisation, it is here argued that European commentators exaggerated Aboriginal violence - particularly inter-gender violence and infanticide - and constructed Aboriginal cannibalism, a manufactured representation which in European minds justified the delineation of Aborigines as 'savages' which, in turn, 'justified' colonisation. This causal link was compounded by misunderstandings concerning Aboriginal ceremonies regarding the deaths of both relatives and enemies. It is further argued in this chapter that Aboriginal agency was a key facet in the conceptualisation of Aborigines as violent, cannibal 'savages'.

Confronting European accusations of Aboriginal cannibalism is perhaps sensitive territory in which to venture. In opposing Obeyesekere's and William Arens' rejection of the 'evidence' on Fijian cannibalism, which he likens to politicians denying pollution-induced global warming, Marshall Sahlins suggests: 
blaming the narratives of cannibalism on imperialism allows the deconstructivist critics to assume the moral high ground, defending the indigenous peoples against a (Western) calumny, which is to say acquitting them of an offence against our morality - and thus accomplishing the intellectual subversion of the peoples' own traditional cultural practices. Talk about imperialism! ${ }^{2}$

The purpose here, however, is not to 'assume the moral high ground'. This study does not seek to verify or deny the consumption of human flesh by Aborigines. Rather, in this chapter it is argued that a close examination of the evidence proposed for Aboriginal cannibalism indicates an overwhelming and simultaneous European fear of and fascination with the practice, and that denoting Aborigines as cannibals served to signify and justify them as 'savages' fit for colonisation, 'civilisation', and Christianisation. As Obeyesekere notes, 'statements about cannibalism reveal more about the relations between Europeans and Savages during early and late contact than, as ethnographic statements, about the nature of Savage anthropophagy' ${ }^{3}$

Obeyesekere further argues that in questioning European narratives of cannibalism 'the strategy of research ought not only to be "deconstructive", as one undermines the truth value of the story, but also "restorative" as one gives back the dignity that has been forcibly taken away from the other during the period of colonial expansion and conquest'. ${ }^{4}$ The intent here is also to be restorative as well as deconstructive, not because cannibalism is undignified, as Obeyesekere implicitly suggests, rather because investigating and

\footnotetext{
2 Marshall Sahlins, 'Artificially Maintained Controversies: Global Warming and Fijian Cannibalism', Anthropology Today, 19:3, 2003, p.3, emphasis in original; Sahlins earlier drew parallels between Arens' argument and other 'outrageous theor[ies], such as the Nazis really didn't kill the Jews, [or] human civilization comes from another planet'; W. Arens and Marshall Sahlins, 'Cannibalism: an Exchange', New York Review of Books, 26:4, 22 March 1979, np

${ }^{3}$ Gananath Obeyesekere, "British Cannibals": Contemplation of an Event in the Death and Resurrection of James Cook, Explorer', Critical Inquiry, 18:4, 1992, pp.630-631

${ }^{4}$ Gananath Obeyesekere, 'Narratives of the Self: Chevalier Peter Dillon's Fijian Cannibal Adventures', in Barbara Creed and Jeanette Hoorn (eds.), Body Trade: Captivity, Cannibalism and Colonialism in the Pacific, New York:2001, p.70
} 
understanding the past is the historian's objective. An analysis of European responses to indigenous violence is vital to understanding empirical writings on such violence.

In studying the voyages of explorer James Cook, Obeyesekere has identified a 'cannibal complex' - a British preoccupation with cannibalism. He argues that this complex was due to three factors: the European reading public wanted to hear tales of cannibalism; cannibalism was what European voyagers expected to encounter; and cannibalism was what Europeans feared above all else. ${ }^{5}$ Obsessive enquiries about cannibalism, Obeyesekere further contends, prompted consistent reactions among the indigenous populations which did not practice cannibalism but whom Cook and his men accused of the practice: first denial, followed by contrived mischievous admissions of cannibalism. ${ }^{6}$

In his discussion of the arguments surrounding supposed cannibalism encountered by Christopher Columbus' expeditions in the Americas, Nicolàs Wey-Gómez notes that the assertions made by Columbus and his men 'do not establish "fact"'. He suggests that claims of the practice of cannibalism in the Lesser Antilles materialised from 'judgement on the basis of "hearsay" provided by Indian informants with whom they could often barely communicate'. ${ }^{7}$ In her article 'Imagining Cannibals' Carol Myscofski further argues that Iberian colonial accounts of the indigenous peoples of Brazil were more about expectations of unfamiliar peoples, and less about surprise at their discoveries. 'These perceptions of non-Europeans', she notes, 'served to justify

\footnotetext{
${ }^{5}$ Obeyesekere is here building upon W. Arens, The Man-Eating Myth: Anthropology \& Anthropophagy, Oxford:1979, passim, esp. p.168; Obeyesekere, 'British Cannibals', p.641

6 Obeyesekere, 'British Cannibals', p.649

7 Nicolás Wey-Gómez, 'A Poetics of Dismemberment: the Book of Job and the Cannibals of Cariay in Columbus's Account of the Fourth Voyage', Colonial Latin American Review, 16:1, 2007, pp.119120
} 
the colonizers' views of and interactions with the native Brazilians'. She concludes: '[a]s the writers told their tales, then, they imagined not just the exotic but what they considered the extremities of human behaviour in barbarity. But their sources were dubious at best' ${ }^{8}$ Later European encounters with Aborigines incorporated American experiences into expectations about 'savages', and repeated the reflection of expectations rather than surprise.

As Kay Schaffer notes in discussing the wake of first contact at Fraser Island in 1836, within a colonial mentality the representation of indigenous peoples as cannibals guaranteed Europeans' superiority: the ultimate mark of 'savagery', accusations of cannibalism served as a definitive denial of common humanity. She observes that reports of first contact between Aborigines and Europeans in diaries, journals, and testimonies were 'framed not only by the historical contexts and limited understandings' of the Europeans involved, 'but also by notions of civility and propriety, primitivism and barbarity already available to them through prior discourses of difference'. Within Europeans' accounts of contact with Aborigines, Schaffer identifies an 'irrational fear of cannibalism, bordering on paranoia'. Cannibalism, she observes, was 'the capital sin of otherness'. ${ }^{9}$

Katherine Biber further shows that ' $[t]$ he discourse of cannibalism is a repeated and powerful trope in colonial contact and conflict'. In her examination of how "“cannibalism" was wielded discursively to differentiate the colonial citizen from savagery, atavism and abjection', Biber argues that the European '[f]ascination with - and accusations of - anthropophagy, ritual

\footnotetext{
${ }^{8}$ Carole A. Myscofski, 'Imagining Cannibals: European Encounters with Native Brazilian Women', History of Religions, 47:2/3, 2007/2008, pp.145 \& 153

${ }^{9}$ Kay Schaffer, In the Wake of First Contact: the Eliza Fraser Stories, Cambridge:1995, pp.106-108; see also: Kay Schaffer, "We are like Eliza”: Twentieth-Century Australian Responses to the Eliza Fraser Saga', in Ian J. McNiven et al. (eds.), Constructions of Colonialism: Perspectives on Eliza Fraser's Shipwreck, London:1998, pp.79-96; Lynette Russell, “Mere trifles and faint representations": the Representations of Savage Life Offered by Eliza Fraser', in McNiven et al. (eds.), pp.56-57
} 
sacrifice and survival cannibalism disclose the fear of the native "Other". '[T]here is', she asserts, 'no credible historical evidence to support allegations that indigenous Australians practised the forms of cannibalism sought by the colonists'. Biber acknowledges the need for caution in applying European labels to indigenous practices, but adds that it is generally accepted that Aboriginal peoples 'in some areas, in rare circumstances, and in the conduct of rituals - practised some forms of anthropophagy, notably mortuary cannibalism' ${ }^{10}$ This is, however, peripheral to this study, in which it is argued that European claims of widespread Aboriginal cannibalism were based on false, if any, evidence and served to justify the Aborigines' assigned place at the bottom of the Europeans' hierarchy of races.

a

Early European explorers who travelled to Asia, and later to the 'furtherAsia' of the Pacific, did so with the stories of Homer, Herodotus, and the Holy Bible in the fore of their minds. ${ }^{11}$ These most revered sources of knowledge both shaped Europeans' preconceptions of peoples they were to encounter and influenced how such encounters were managed.

European visitors to newly discovered lands were often quick to draw parallels with the ancient Greeks and Romans, as is evinced by Salmond's discussions of European exploration of the Pacific, particularly Tahiti. ${ }^{12}$ Gentleman-botanist Joseph Banks in particular had Greek and Roman mythology in the fore of his mind when he visited the South Seas. ${ }^{13}$ He called Tahiti 'Ar-

10 Katherine Biber, 'Cannibals and Colonialism', Sydney Law Review, 27:4, 2005, pp.624-626

11 P.J. Marshall and Glyndwr Williams, The Great Map of Mankind: British Perceptions of the World in the Age of Enlightenment, London:1982, pp.7-12 \& 37-40; Tony Ballantyne, Orientalism and Race: Aryanism in the British Empire, New York:2002, pp.56-57

12 Salmond, Trial; Salmond, Aphrodite's Island

13 Thomas, Discoveries, pp.31-32 
cadia', and labelled numerous Tahitian chiefs after heroes of Greek and Roman antiquity. Upon one man he bestowed the name Mentor, recalling Odysseus' good friend. ${ }^{14}$ In the latter half of the eighteenth century Europeans were encountering newly discovered peoples with the writings of Greek and Roman antiquity in mind.

These writings of antiquity often evoked notions of cannibalism. In his Odyssey, Homer signified two types of people and demonstrated the fear of 'the other'. When encountering an unknown people, Homer's hero Odysseus declared they would either be 'aggressive savages with no sense of right or wrong or hospitable and god-fearing people'. ${ }^{15}$ At one point in the poem an encountered stranger turns out to be the former - a giant cyclops no less. And when '[l]imb by limb he tore them to pieces to make his meal', Odysseus wept 'in horror at the ghastly sight' of cannibalism. ${ }^{16}$

Herodotus reported cannibalism among the Issedones and the Scythian Massagentae - peoples beyond the boundaries of the Greek Empire, in what is now Eastern Europe. Strabo, another Greek historian, asserted cannibalism was commonplace in Ireland. ${ }^{17}$ In the book of Genesis it is written that God said: '[e]very moving thing that liveth shall be meat for you; even as the green herb have I given you all things. But flesh with the life thereof, which is the blood thereof, shall ye not eat' - often interpreted as a command against cannibalism. ${ }^{18}$ Roman propagandists, however, publicly accused

\footnotetext{
14 Salmond, Aphrodite's Island, pp.146-147; B. Smith, European Vision, pp.41-42; B. Smith, Imagining the Pacific, pp.213-224

15 Homer, The Odyssey, D.C.H. Rieu (revised trans.), London:1991, pp.114-115, see also: pp.79 \& 147

16 ibid., p.117

17 Gary Hogg, Cannibalism and Human Sacrifice [1958], Stroud, Gloucestershire:2007, p.18; Richard Hall, Black Armband Days: Truth from the Dark Side of Australia's Past, Sydney:1998, p.167; Arens, Man-Eating Myth, pp.10 \& 165-166

${ }^{18}$ Genesis 9:3-4, Holy Bible, King James Version (KJV); infanticide is also at times interpreted as being biblically prohibited by Jeremiah 32-35 and Psalm 106:37-48
} 
Christians of infant cannibalism. Upon returning from his prolonged sojourn to East Asia, Marco Polo claimed that many peoples of China and Tibet were cannibals. ${ }^{19}$ These and many other examples indicate that Europeans have a longstanding fear of and obsession with cannibalism. This morbid fascination shaped their encounters with newly discovered peoples.

The European fascination with cannibalism is also well documented temporally closer to European-indigenous contact in the Tasman world. In Daniel Defoe's 1719 novel Robinson Crusoe, the protagonist encountered cannibalism among indigenous peoples of the Caribbean. Defoe wrote of 'savage wretches' conducting 'inhuman feastings upon the bodies of their fellow creatures'. The English author further canvassed an appropriate response to such an encounter: his hero 'dreamed often of killing savages' ${ }^{20}$ Defoe's novel was extremely popular in Britain at the end of the eighteenth and the beginning of the nineteenth centuries. When Europeans encountered Aborigines and other indigenous people during this period, tales of 'the other' were often in the fore of their minds. To borrow from Obeyesekere: 'the monsters of the imagination', were 'projected onto the psychic or cultural life of the savage' ${ }^{21}$

In 1519, at the eastern entrance to the Pacific, upon being first encountered by Europeans the indigenous peoples of Tierra del Fuego were described by Portuguese-born Spanish explorer Ferdinand Magellan as 'of a prodigious stature, fierce, and barbarous, [who] made a horrible roaring noise, more like

\footnotetext{
19 Hogg, p.18

20 Daniel Defoe, The Life and Strange Surprizing Adventures of Robinson Crusoe [1719], New York:1963, pp.173, $179 \& 193$

${ }^{21}$ Gananath Obeyesekere, Cannibal Talk: the Man-Eating Myth and Human Sacrifice in the South Seas, Berkeley:2005, pp.13-14
} 
bulls than human creatures' ${ }^{22}$ The western entrance to the Pacific was also initially reported to be guarded by giants. After three days at anchor in Van Diemen's Land in early-December 1642, although no Aborigines were encountered, Dutch explorer Abel Tasman's crew reported finding foot notches cut into trees spaced five feet apart. Tasman fled eastward, having concluded that giants lived on the island: the Europeans 'presumed, here to be Very tall people'. ${ }^{23}$ Europeans fearfully expected to encounter monsters when they entered the Pacific.

Between 29 April and 5 May 1770, while anchored in Botany Bay, the crew of the Endeavour first encountered Aboriginal peoples of New Holland. Their preceding contact with indigenous peoples was prolonged interaction with Māori, experienced during their lengthy circumnavigation of New Zealand. ${ }^{24}$ With notions of Māori as a warlike people fresh in their minds - a conceptualisation which is examined in chapter two - the Europeans (and their Ra'iatean companion Tupaia) sought to establish if the same could be said for the Aboriginal peoples of what Cook named New South Wales.

Upon first sighting Aborigines Cook expressed his disappointment that they 'took to the woods' as the Europeans approached. Evincing Māori were in the fore of his mind, he then noted that the Europeans saw ' 3 or 4 small Canoes which to us appear'd not much unlike the small ones of New Zea-

\footnotetext{
22 quoted in Marshall and Williams, p.261; B. Smith, European Vision, pp.34-41; B. Smith, Imagining the Pacific, pp.54-62

${ }^{23}$ Abel Tasman, The Voyages of Abel Janszoon Tasman, Andrew Sharp (ed.), London:1968, p.110

${ }^{24}$ Glyndwr Williams, "'Far More Happier Than We Europeans": Reactions to the Australian Aborigines on Cook's Voyage', Historical Studies, 19:77, 1981, p.500
} 
land' ${ }^{25}$ When, the following day, a party landed on shore 'in hopes of speaking with them', the Aborigines 'all made off except two Men who seemd resolved to oppose our landing'. ${ }^{26}$ As Banks had already assumed Aboriginal spears were poisoned, Cook was hesitant to follow the Aborigines inland. There is relatively little evidence of what Aboriginal-European interactions occurred during this period, but five days after arriving in Botany Bay Banks noted that he was able to go 'in the woods botanizing as usual, now quite void of fear as our neighbours have turnd out such rank cowards' ${ }^{27}$

The interactions between Europeans and Aborigines related in the Endeavour journals are often accounts of Aborigines fleeing upon seeing the strangers. Tupaia, who had been vital to the Endeavour crew learning so much about Māori, was again expected to act as an interpreter, yet he found he could not understand these peoples' languages. He too found that Aborigines fled upon his coming across them. As Banks wrote: 'Tupia, who parted from us and walkd away a shooting, on his return told us that he had seen 2 people who were digging in the ground for some kind of roots; on seeing him they ran away with great precipitation.' ${ }^{28}$

Tupaia and the European crew of the Endeavour made ten landfalls on the east coast of Australia: one at Botany Bay and a further nine north of the Tweed River in what is now Queensland. ${ }^{29}$ Of these ten, it was only during

\footnotetext{
25 James Cook, The Journals of Captain James Cook on his Voyages of Discovery, J.C. Beaglehole (ed.), 4 vols., Cambridge:1955-1974, 28 April 1770, i:p.304

26 ibid., 29 April 1770, i:pp.304-305; Richard Broome, 'The Struggle for Australia: AboriginalEuropean Warfare, 1770-1930', in McKernan and Browne (eds.), pp.92-93

27 Joseph Banks, The Endeavour Journal of Joseph Banks, 1768-1771, J.C. Beaglehole (ed.), 2 vols., Sydney:1962, 4 May 1770, ii:p.59

28 ibid., 5 July 1770 , ii:p.88

${ }^{29}$ Malcolm D. Prentis, 'Prelude to Dispossession? First Contacts between Aborigines and Europeans in the Northern Rivers Region of New South Wales, 1770-1840s', Journal of the Royal Australian Historical Society [JRAHS], 70:1, 1984, p.3
} 
their prolonged stay at Endeavour River that the Europeans were able to have more than cursory interactions with Aboriginal peoples.

Banks took leave of New South Wales by 'summing up together the few observations I have been able to make on the countrey and people'. After wishing he had 'had better opportunities of seeing and observing the people', and dismissing William Dampier's earlier observations of Aboriginal peoples of New Holland because 'he was in a ship of Pyrates, possibly himself not a little tainted by their idle examples', Banks observed a 'want of People'. For this asserted sparse population he offered two reasons: 'the Barreness of the Soil and scarcity of fresh water', or that 'their small tribes have frequent wars in which many are destroyd'. He continued with a long description of Aboriginal weaponry, concluding that Aborigines were 'a very pusilanimous people' and, excepting one instance when two men had opposed the Europeans landing 'till several times wounded with small shot ... they behavd alike, shunning us and giving up any part of the countrey which we landed upon at once' ${ }^{30}$

The Endeavour reports on Aborigines, which verge on being contradictory - a cowardly people often in combat - read as though written in search of a warlike people. Aborigines did in fact actively resist the European presence during the Endeavour's visit. At Endeavour River an Aboriginal man was shot by the visitors for attempting to drive them away with fire. As Banks reported, 'they seizd their arms in an instant, and ... began to set fire to the grass to windward of the few things we had left ashore with surprizing dexterity and quickness; the grass which was 4 or 5 feet high and as dry as stub-

\footnotetext{
30 Banks, 'Some account of that part of New Holland now called New South Wales', Journal, c.26 August 1770, ii:pp.111-137
} 
ble burnt with vast fury'. ${ }^{31}$ Earlier, at Botany Bay, two Aboriginal men armed with spears and woomera appeared ready to resist the arrival of the strangers. Cook noted 'all they seem'd to want was for us to be gone'. ${ }^{32}$

Despite such active resistance and a belief in frequent inter-tribal violence in which many were killed, with Māori as a point of contrast Banks wrote of Aborigines' 'unaccountable timidity' and declared them to be 'rank cowards'. ${ }^{33}$ Cook, again with memories of Māori in mind, concluded: 'I do not look upon them to be a warlike People, on the Contrary I think them a timorous and inoffensive race, no ways inclinable to cruelty'. ${ }^{34}$ As Ann McGrath notes, "[a]long with the romantic "noble savage" depictions, Cook and Banks had left impressions that the men were cowardly, unfriendly and vindictive' $^{35}$

While he claimed the Aboriginal peoples of Tasmania to be giants, Tasman had not explicitly reported that Aborigines might be cannibals. Neither did Cook, although based on their interactions with Māori it is likely he and his crew enthusiastically sought evidence of the practice. Nevertheless, nine years after the Endeavour encountered Aboriginal peoples of New South Wales J. Carver hypothesised that the apparently sparse Aboriginal population reported in the Endeavour journals was probably due to 'the horrid appetite for devouring each other, which prevails in New Zealand' ${ }^{36}$

\footnotetext{
31 Banks, Journal, 19 July 1770, ii:pp.95-97

32 Cook, Journal, 30 April 1770, i:p.306

${ }^{33}$ Banks, Journal, 7 July \& 4 May 1770, ii:pp.90 \& 59

34 Cook, Journal, 23 August 1770, i:p.396; the conceptualisation of Māori violence which influnced these reactions was itself influenced by preceding encounters with Tahitians; Standfield, 'Warriors and Wanderers', pp.42-46

35 Ann McGrath, 'The White Man's Looking Glass: Aboriginal-Colonial Gender Relations at Port Jackson', Australian Historical Studies, 24:95, 1990, p.202

${ }^{36}$ J. Carver, The New Universal Traveller, Containing a Full and Distinct Account of all the Empires, Kingdoms, and States, in the Known World, London:1779, p.665
} 
The complex cannibal myth persisted through the nineteenth century and into the twentieth. When Cook's Endeavour journal was finally published in full in 1893 - prior to which John Hawkesworth's edited compilation of Cook's and Banks' journals was the most widely circulated version of the Endeavour crew's observations - the editor Captain W.J.L. Wharton added a footnote to Cook's assertion that Aborigines were 'far more happier than we Europeans' (which Hawkesworth had brazenly instead applied to the indigenous people of Tierra del Fuego). ${ }^{37}$ Wharton asserted:

[t]he native Australians may be happier in their condition, but they are without doubt among the lowest of mankind. Confirmed cannibals, they lose no opportunity of gratifying their love of human flesh. Mothers will kill and eat their own children ... Internecine war exists between the different tribes ... Their treachery, which is unsurpassed, is simply an outcome of their savage ideas. ${ }^{38}$

Obeyesekere argues '[i]f the monsters of the medieval imagination were symbolically or metaphorically represented in the new wild man, the savage of the voyages of discovery, so also was the cannibal, initially in the Americas and then much later in the South Seas'. ${ }^{39}$ Europeans expected the new lands of the Pacific to be populated with cannibal monsters, and even when empirical evidence failed to confirm these expectations the myth prevailed.

Initial European inhabitants of Australia quickly sought to establish if the Aboriginal peoples of the continent were cannibals. When a convict reported that he had seen the head of another prisoner, Peter Burn, who was believed to have been captured by Aborigines in May 1788, 'lying near the place

\footnotetext{
37 John Hawkesworth, An Account of the Voyages Undertaken by the Order of His Present Majesty for Making Discoveries in the Southern Hemisphere, 3 vols., London:1773, ii:p.59; W.H. Pearson, 'Hawkesworth's Alterations', Journal of Pacific History (JPH), 7, 1972, pp.48-49; B. Smith, European Vision, p.38; Standfield, 'Warriors and Wanderers', p.67

38 James Cook, Captain Cook's Journal during his First Voyage, W.J.L. Wharton (ed.), London:1893, p. $232 n$

39 Obeyesekere, Cannibal Talk, p.14
} 
where the body had been burnt in a large fire', cannibalism was assumed. Alluding to the discussion which arose from this report, First Fleet Officer of Marines Watkin Tench observed 'there seems no reason to suppose these people cannibals'.$^{40}$ Nevertheless, some convicts and colonial officials assumed Aboriginal cannibalism.

Schaffer, however, states that claims of Aboriginal cannibalism were exceedingly rare in the local press from first settlement in 1788 until the European expansion over the Blue Mountains in the late-1820s. ${ }^{41}$ Following the pastoral expansion west, the Sydney Gazette began publishing letters from settlers accusing Aboriginal peoples of cannibalism. These claims, she notes, which not incidentally coincided with increased pastoralist-Aboriginal contact, 'helped to justify colonial practices of extermination' ${ }^{42}$ When the European-Aboriginal contest over land intensified, European claims of Aboriginal cannibalism increased, as Europeans sought to verify Aboriginal 'savagery' and therefore justify their often violent colonisation of Aboriginal lands.

Having begun with the crew of the Endeavour in 1770, the comparison of Aborigines and Māori was not uncommon in the early-nineteenth century. Surgeon Peter Cunningham compared the two indigenous populations in his book Two Years in New South Wales. 'Cannibalism, there is great reason to believe', he wrote, 'has been a very general custom among all nations in the early stages of civilisation, and doubtless brought about by the instinct of

\footnotetext{
${ }^{40}$ Watkin Tench, Sydney's First Four Years: Being a Reprint of 'a Narrative of the Expedition to Botany Bay' and 'a Complete Account of the Settlement at Port Jackson' [1789 \& 1793], Sydney:1961, pp. 48 \& $48 n$

${ }^{41}$ One notable exception is an 1804 article in which a correspondent wrote of Aboriginal peoples' 'natural indolence [which] must in process of time have reduced them to the horrible necessity of existing as cannibals'; Sydney Gazette and New South Wales Advertiser, 24 June 1804, p.3

${ }^{42}$ Schaffer, In the Wake of First Contact, p.118
} 
self-preservation, operating through war or famine ... it exists still in New Zealand in full force, and among some of our own Australian tribes' ${ }^{43}$

In hypothesising that Australia had been settled in two waves by Aboriginal peoples, Cunningham believed that the descendent tribes of the second wave of migration 'are much feared by the other natives, with whom they are commonly in a state of hostility. They are in fact pronounced to be cannibals by the others, and such appears to be the opinion generally entertained of all the mulatto tribes by their darker brethren'. Cunningham levelled allegations of anthropophagy at various language groups, claiming to have 'no doubt of the fact'. His evidence was that some Aborigines told him that language groups hostile to their own were cannibals, and that some Aborigines responded positively to leading questions about cannibalism. ${ }^{44}$ Such Aboriginal accusations and 'confessions' should not necessarily be taken as evidence of cannibalism.

Like European assertions of Aboriginal cannibalism, European writings on Aboriginal inter-gender violence were also constructed to confirm Aboriginal peoples as 'savages'. Aboriginal inter-gender violence was often portrayed in terms of inter- as well as intra-language group violence. The construction of Aboriginal men as violent towards women and of Aboriginal women as brutalised has been recently explored by a number of historians, and is briefly canvassed here as it relates to the wider conceptualisation of Aborigines as violent 'savages'.

\footnotetext{
43 P. Cunningham, Two Years in New South Wales, 2 vols., London:1827, ii:p.3; K.R. Howe, Race Relations Australia and New Zealand: a Comparative Survey, 1770's-1970's, Wellington:1977, pp.1120; Standfield, Race and Identity in the Tasman World, passim

${ }^{44}$ Cunningham, ii:pp.2-4
} 
The construction of Aboriginal men as violent towards women began with observers of the First Fleet. Tench reported that

indeed the women are in all respects treated with savage barbarity; condemned not only to carry the children, but in all other burthens, they meet in return for their submission only with blows, kicks, and every other mark of brutality. When an Indian [Aboriginal] is provoked by a woman, he either spears her, or knocks her down on the spot: on this occasion he always strikes on the head, using indiscriminately a hatchet, a club, or any other weapon, which may chance to be in his hand. ${ }^{45}$

As McGrath notes, Tench invoked the same 'savage' imagery already in circulation in North American literature, and found that Aboriginal women's work did not conform to the British ideal. He thus perceived Aboriginal women to be slaves of subsistence and sex to Aboriginal men. ${ }^{46}$

In his History of New South Wales (1802), George Barrington observed of Aboriginal men:

their conduct to women renders them considerably inferior to the brute creation ... In obtaining a female partner the first step they take, romantic as it may seem, is to fix on some female of a tribe at enmity with their own ... The monster then stupefies her with blows, which he inflicts with his club, on her head, back, neck, and indeed every part of her body, then snatching up one of her arms, he drags her, streaming with blood from her wounds, through the woods, over stones, rocks, hills, and logs, with all the violence and determination of a savage, till he reaches his tribe, when a scene takes place with the relation of which I shall neither stain my pages nor offend the reader. ${ }^{47}$

45 Tench, pp.290-291; on French observations of Aboriginal violence during this period see: Colin Dyer, 'The Indigenous Australians in Sydney and its Environs as Seen by French Explorers, 1802-1831', JRAHS, 88:2, 2002, pp.153-157; Colin Dyer, The French Explorers and the Aboriginal Australians, 1772-1839, Brisbane:2005

46 Ann McGrath, “"Modern Stone-Age Slavery”: Images of Aboriginal Labour and Sexuality', Labour History, 69, 1995, p.33

47 George Barrington, The History of New South Wales [1802], second edition London:1810, p.35 
As McGrath observes, this and other tales of violent courtship and marriage were repetitive and lacked the specific details of time, place, and characters, indicating that they were likely exaggerated from an isolated incident. 'The author knows what savages are like, and so does the reader, and this merely confirms what they already believe'. ${ }^{48}$ The point is equally applicable to accusations of Aboriginal cannibalism and other forms of conceptualised Aboriginal violence.

Like historical accusations of cannibalism, the portrait of violent Aboriginal inter-gender relations depicted by nineteenth-century Europeans continues to be repeated. Robert Hughes writes that both before and after betrothal, an Aboriginal woman 'was merely a root-grubbing, shell-gathering chattel, whose social assets were wiry arms, prehensile toes and a vagina'. ${ }^{49}$ In his Fabrication of Aboriginal History, Keith Windschuttle argues with regard to the depopulation of the Aboriginal peoples of Tasmania: ' $[t]$ he real tragedy of the Aborigines was not British colonization per se but that their society was, on the one hand, so internally dysfunctional and, on the other hand, so incompatible with the looming presence of the rest of the world'. 'They had survived for millennia, it is true', he concedes, but 'it seems clear that this owed more to good fortune than good management ... Hence it was not surprising that when the British arrived, this small, precarious society quickly

48 McGrath, 'Modern Stone-Age Slavery', p.35; see also: McGrath, 'White Man's Looking Glass', pp.189-206; Shino Konishi, "'Wanton with Plenty": Questioning Ethno-historical Constructions of Sexual Savagery in Aboriginal Societies, 1788-1803', Australian Historical Studies, 39:3, 2008, pp.356372; Patricia Grimshaw, 'Maori Agriculturalists and Aboriginal Hunter-Gatherers: Women and Colonial Displacement in Nineteenth-Century Aotearoa/New Zealand and Southeastern Australia', in Ruth Roach Pierson and Nupur Chaudhuri (eds.), Nation, Empire, Colony: Historicizing Gender and Race, Bloomington, Indiana:1998, pp.21-40; Lynette Russell, “'Dirty Domestics and Worse Cooks": Aboriginal Women's Agency and Domestic Frontiers, Southern Australia, 1800-1850', Frontiers: $a$ Journal of Women Studies, 28:1-2, 2007, pp.18-46; Broome, Aboriginal Australians, pp.19-20; Norbert Finzsch, "It is scarcely possible to conceive that human beings could be so hideous and loathsome": Discourses of Genocide in Eighteenth- and Nineteenth-Century America and Australia', Patterns of Prejudice, 39:2, 2005, pp.112-113

49 Robert Hughes, The Fatal Shore: the Epic of Australia's Founding, New York:1987, p.16 
collapsed under the dual weight of the susceptibility of its members to disease and the abuse and neglect of its women'.

Windschuttle blames the drastic depopulation of the Tasmanian Aborigines on Aboriginal inter-gender relations. He asserts that ' $[t]$ he aspect of their society that left them most vulnerable in the face of the European arrival was the treatment of their women', surmising that they were 'active agents in their own demise because their men hired out and sold off their women without seriously contemplating the results'. 'Only men who held their women cheaply', Windschuttle concludes, 'would allow such a thing to happen'. ${ }^{50}$ As James Boyce and others have shown, Windschuttle's supposed 'abundant evidence' for such claims is thin, and that which is offered is fundamentally flawed. ${ }^{51}$ Lynette Russell argues that interactions between Tasmanian Aboriginal women and European sealers, to which Windschuttle refers, 'need to be seen in context with an understanding of women's agency and autonomy in traditional society', and shows that these encounters were 'based on negotiation and liaison on both sides'. 'Aboriginal people', she demonstrates, 'and especially the sealing women, resisted, adapted, negotiated, and survived by various means' ${ }^{52}$

Aboriginal women did not passively submit to inter-gender violence. Nineteenth-century historian James Bonwick noted that Tasmanian Aboriginal women exacted revenge for brutal treatment at the hands of Europeans by

\footnotetext{
50 Keith Windschuttle, The Fabrication of Aboriginal History, Volume One: Van Diemen's Land, 1803-1847, Sydney:2002, pp.386 \& 379; see also: Inga Clendinnen, Dancing with Strangers, Melbourne:2003, pp.159-167

51 Robert Manne (ed.), Whitewash: on Keith Windschuttle's Fabrication of Aboriginal History, Melbourne:2003, passim, esp. James Boyce, 'Fantasy Island', pp.63-67; and Lyndall Ryan, 'Who Is the Fabricator?', pp.230-257; see also: Lyndall Ryan, Tasmanian Aborigines: a History Since 1803, Sydney:2012, passim, esp. pp.xix-xxii

52 Russell, 'Dirty Domestics and Worse Cooks', pp.21, 23 \& 28
} 
torturing captured men, using 'sharp stones upon secret parts'. ${ }^{53}$ As McGrath notes, Aboriginal law had safeguards to prevent unwarranted violence by men towards women. ${ }^{54}$ These safeguards were, however, drastically disrupted by contact with Europeans. European men slept with Aboriginal women, who were at times willing and at other times unwilling partners; both instances often disrupted traditional Aboriginal betrothals and laws regarding sex. Furthermore, European philanthropists and colonial officials saw traditional laws managing sexual relations, and particularly the enforcement of these laws, as 'uncivilised' and unchristian and therefore sought to prevent them, which compounded the disruption. ${ }^{55}$ A degree of violence was unleashed by colonisation, but this was greatly exaggerated. Europeans, contact with whom placed great stress on Aboriginal societies, conceptualised Aboriginal inter-gender relations as violent as part of the depiction of Aboriginal peoples as violent 'savages'.

Aboriginal peoples traditionally held a deep mistrust and intense fear of unknown Aborigines - whom they frequently termed 'wild blacks'. Often believed to be capable sorcerers, strange Aborigines were generally to be killed if encountered in one's country. ${ }^{56}$ Aboriginal informants at times described

\footnotetext{
53 James Bonwick, The Last of the Tasmanians; or, the Black War of Van Diemen's Land, London:1870, p.108

54 McGrath, 'Modern Stone-Age Slavery', p.37

55 'Philanthropists' is preferred to the more popular label 'humanitarians' here, and throughout this thesis, because the former was used contemporaneously; Claire McLisky, "'Due Observance of Justice, and the Protection of their Rights": Philanthropy, Humanitarianism and Moral Purpose in the Aborigines Protection Society circa 1837 and its Portrayal in Australian Historiography, 1883-2003', Limina, 11, 2005, pp.57-66

56 J. Mitchell, "“Country Belonging to Me”: Land and Labour on Aboriginal Missions and Protectorate Stations, 1830-1850', ERAS, 6, 2004, np; Beverley Nance, 'The Level of Violence: Europeans and Aborigines in Port Phillip, 1835-1850', Historical Studies, 19:77, 1981, p.534; Broome, 'Struggle for Australia', pp.109-112; Edmund J.B. Foxcroft, Australian Native Policy: Its History, Especially in Victoria, Melbourne:1941, pp.14-16; G.A. Robinson, 16 July 1841, 'In Quest of the Tribes: G.A. Robinson's Unabridged Report of his 1841 Expedition among Western Victorian Aboriginal Tribes; Ken-
} 
'wild blacks' or their known neighbouring enemies as anthropophagous to Europeans. Upon discovering that Europeans were frightened and disgusted by, yet also obsessed with, cannibalism, as indicated by their persistent enquiries about and reactions to discussions of the practice, Aborigines expanded on the belief in 'wild blacks' as frightening and wicked to assert that they were anthropophagous as well. The Tharawal of Jervis Bay, for example, told colonists in 1814 that the 'mountain tribes' were cannibals. ${ }^{57}$ In 1825 a Wellington Valley missionary was told by a group of Aborigines that 'twenty days journey from them' was another language group who were cannibals, for they 'eat black fellow'.58 The European belief that a people were anthropophagi often arose, therefore, from accusations of cannibalism by traditional enemies of those accused. ${ }^{59}$ These accusations should not necessarily be taken as evidence of Aboriginal cannibalism.

Moreover, much Aboriginal information was (and is) available only to those who were initiated, and those who were initiated were well aware of the strict requirement that such information was not to be shared with the uninitiated. A.W. Howitt noted in 1888 that ' $[t]$ he aborigines are very reticent on the subject [of initiation ceremonies]; moreover, of the very few white men who have become initiated, few have been competent to record the necessary particulars, even if they had thought of doing so'. He added that the 'wild white man' William Buckley, for example, made no mention of Aboriginal initiation ceremonies because, while '[i]t is scarcely likely that ... he was not

yon's “Condensation” Reconsidered', Ian D. Clark (ed.), Memoirs of the Museum of Victoria. Anthropology and History, 1:1, 1990, p.114; cf. G.A. Robinson, 16 \& 17 July 1841, 'The Aboriginal Protectorate of Port Phillip: Report of an Expedition to the Aboriginal Tribes of the Western Interior by the Chief Protector, George Augustus Robinson', A.S. Kenyon (ed.), Victorian Historical Magazine [VHM], 12:3, 1928, p.158; see also: G.A. Robinson, 17 July 1841, The Journals of George Augustus Robinson, Chief Protector, Port Phillip Aboriginal Protectorate, 1839-1852 [1998], Ian D. Clark (ed.), 6 vols., second edition Ballarat:2000, pp.310-311

57 Sydney Gazette and New South Wales Advertiser, 4 June 1814, p.2

58 ibid., 28 November 1825, p.2

59 Arens, Man-Eating Myth, pp.44-46 
present at several of their gatherings ... he refrained from describing that which during so many years he must have been told it was not lawful to disclose to the uninitiated'. ${ }^{60}$ The explanation that Aboriginal reticence caused many problems for Europeans seeking to access information regarding ceremonies can be expanded to many aspects of Aboriginal life, therefore compounding Europeans' misunderstandings about facets of Aboriginal beliefs and customs.

On the other hand, Aborigines certainly often struggled to convey complex beliefs, customs, and practices to Europeans, just as Europeans often found in attempting to express European ideas to Aborigines. Howitt, for example, noted that he used, 'at the time unconsciously ... words which in fact imply the sun moves from east to west, and sinks beyond the western edge of the world' when conversing with Aborigines. ${ }^{61}$ It is extremely important to remember that texts relating exchanges between Aborigines and Europeans were paraphrased by their European authors as they later recalled conversations, adding or omitting context, either consciously or unconsciously. These conversations, often about extremely complex matters, were, furthermore, likely conducted through a mixture of pidgin-English, an assortment of pidgin-Aboriginal dialects, expressions, and gestures - with abundant room for misunderstandings on both sides.

The colonial officials of the Port Phillip Aboriginal Protectorate often reported on Aboriginal relationships with strange and enemy Aboriginal peoples. The philanthropists noted, for example, that the Wathaurong and Djadjawurung called their neighbours who spoke a different language and with

\footnotetext{
60 A.W. Howitt, 'On Some Australian Ceremonies of Initiation', Journal of the Anthropological Institute of Great Britain and Ireland (JAIGBI), 13, 1884, pp.432 \& 432n

${ }^{61}$ See also the discussion of the problems relating to evangelicals discussing death with Aboriginal peoples in chapter three; A.W. Howitt, 'On Australian Medicine Men; or, Doctors and Wizards of Some Australian Tribes', JAIGBI, 16, 1887, p.54
} 
whom they did not marry 'mainmait', meaning strange Aborigines who practised sorcery against them. ${ }^{62}$ Aborigines feared their known enemies and unknown Aboriginal peoples, and often sought to communicate this fear to Europeans.

In response to an inquiry as to whether Aboriginal peoples had 'any idea of property in land', Presbyterian minister John Dunmore Lang used an example he felt his European audience could relate to. Lang told the Aborigines Protection Society:

as the European regards the intrusion of any other white man upon the cattle-run, of which European law and usage have made him the possessor, and gets it punished as trespass, the Aborigines of the particular tribe inhabiting a particular district, regard the intrusion of any other tribe of Aborigines upon that district, for the purposes of kangaroo hunting, \&c. as an intrusion, to be resisted and punished by force of arms. ${ }^{63}$

In his paper 'On Some Australian Beliefs', Howitt noted that 'the words Kŭrnai, Külin, and Murring are all synonymous, meaning "men," in distinction to other blackfellows whom the respective Kŭrnai, Kūlin, or Murring designate "wild men," "snakes," "come-by-night," or other similar terms of contempt or fear' ${ }^{64}$ The Kurnai of Gippsland called the Boonwurrung of Westernport 'Thurung' - tiger snakes - because 'they came sneaking about to kill us'. ${ }^{65}$

Aboriginal peoples naturally sought to convey their fear of 'wild blacks' to Europeans in a manner which they believed the newcomers could under-

62 Robinson, 30 March 1841, 'In Quest of the Tribes', Clark (ed.), pp.102-104

63 'Papers and Proceedings of the Aborigines Protection Society', v, 1839, pp.140-144, in Henry Reynolds (ed.), Dispossession: Black Australians and White Invaders, Sydney:1989, p.74, emphasis in Reynolds

${ }_{64}$ A.W. Howitt, 'On Some Australian Beliefs', JAIGBI, 13, 1884, p.185, italics in original

${ }^{65}$ A.W. Howitt, The Native Tribes of South-East Australia, London:1904, p.41; Christie, pp.19-20; Ian D. Clark and Toby Heydon, A Bend in the Yarra: a History of the Merri Creek Protectorate Station and Merri Creek Aboriginal School 1841-1851, Canberra:2004, p.11 
stand, thus they applied their knowledge of the European simultaneous aversion to yet fascination with cannibalism in telling Europeans that 'wild blacks' or neighbouring enemies were cannibals. Assistant Protector Dredge observed in 1842: 'each tribe has its own territory, well defined by natural boundaries ... Within these boundaries of their own country, as they proudly speak, they feel a degree of security and pleasure which they can find nowhere else'. ${ }^{66}$ Fellow protector William Thomas noted that while ' $[\mathrm{m}]$ ost tribes have intercourse or hold a kind of alliance with three or four neighbouring ones ... All the tribes beyond the district of their friends are termed wild blackfellows, and when found within the district are immediately killed' ${ }^{67}$ E.M. Curr asserted: '[s]hould Blacks at any time come on a man with whom they are unacquainted, they invariably kill him if possible. ${ }^{68}$

Bond with country was a principal facet of Aboriginal life. Aboriginal peoples had a complex system of language group confines, and each individual knew where he or she was allowed to be, and understood the consequences of visiting country in which they were not allowed. ${ }^{69}$ The intrusion of

\footnotetext{
${ }^{66}$ Dredge, diary, cited in Rhonda Dredge, “'An awful silence reigns": James Dredge at the Goulburn River', La Trobe Journal, 61, 1998, p.25, emphasis in R. Dredge

${ }^{67}$ William Thomas, 'Brief Account of the Aborigines of Australia Felix', nd, in Thomas Francis Bride (ed.), Letters from Victorian Pioneers: a Series of Papers on the Early Occupation of the Colony, the Aborigines, Etc. [1898], Melbourne:1983, p.401; on pre-contact language group conflict, which was highly ritualised, see also: John Morgan, The Life and Adventures of William Buckley, Hobart:1852, passim, esp. pp.32-45; Ronald M. Berndt and Catherine H. Berndt, The World of the First Australians, Aboriginal Traditional Life: Past and Present [1964], fifth edition Canberra:1988, pp.356-362; Broome, 'Struggle for Australia', pp.109-111; John Connor, The Australian Frontier Wars, 1788-1838, Sydney:2002, pp.1-7; Henry Reynolds, 'Blainey and Aboriginal History', in Andrew Markus and M.C. Ricklefs (eds.), Surrender Australia? Essays in the Study and Uses of History: Geoffrey Blainey and Asian Immigration, Sydney:1985, pp.82-89; cf. Geoffrey Blainey, Triumph of the Nomads: a History of Ancient Australia [1975], revised edition Sydney:1983, pp.105-113

${ }^{68}$ E.M. Curr, The Australian Race: Its Origin, Languages, Customs, Place of Landing in Australia, and the Routes by Which it Spread Itself Over that Continent, 4 vols., Melbourne:1886-1887, i:p.86

${ }^{69}$ W.E.H. Stanner, 'Aboriginal Territorial Organization: Estate, Range, Domain and Regime', Oceania, 36:1, 1965, pp.1-26
} 
neighbouring enemies or unknown 'wild blacks' into one's country was often met with suspicion and resolved with violence.

Part of Aboriginal peoples' intense fear and mistrust of enemies or 'wild blacks' was a dread of sorcery. Thomas reported his astonishment at the unshakable belief Aborigines had in the effects of sorcery. '[I]t is surprising (the aged especially) how determined tenaciously they adhere to their old superstitious notions that the dead have been killed', he wrote, adding that the cause of death was believed to be 'that their Marmbulla (kidney fat) has been abstracted from them'.$^{70}$ The vast majority of Aboriginal deaths were believed to have been caused by sorcerers of unknown or enemy groups, generally through the extraction of kidney fat.

Howitt struggled to understand Aboriginal sorcery in European terms. In labelling (and thus differentiating) 'medicine men', 'doctors', 'wizards', 'wizards proper', 'supernatural beings', 'rain-makers', 'spirit-mediums', and 'specialists', Howitt attempted to Europeanise Aboriginal concepts. In doing so, although he acknowledged that Aboriginal 'doctors' and 'wizards' believed in their own abilities, he dismissed their deeds as "no more than the actions of cunning cheats by which they influence others to their own personal benefit' ${ }^{71}$

The Europeanisation of Aboriginal concepts is problematic. As W.E.H. Stanner noted of the Dreaming: '[a] concept so impalpable and subtle naturally suffers badly by translation into our dry and abstract language. ${ }^{72}$ His point is equally applicable to other Aboriginal concepts, such as sorcery. Further-

\footnotetext{
70 Thomas, 'Quarterly Report of 1 March to 31 May 1848', cited in Nance, p.535

${ }^{71}$ A.W. Howitt, 'On Australian Medicine Men', pp.24-25; George Gordon McCrae, 'The Early Settlement of the Eastern Shores of Port Phillip Bay, with a Note on the Aborigines of the Coast', VHM, 1:1, 1911, pp.21-24; Curr, Australian Race, i:pp.45-51

72 Stanner, White Man Got No Dreaming, pp.23-24
} 
more, the dismissal of Aboriginal sorcery as 'cheating' detracts from the important point that it was real to Aborigines; believing in sorcery, they acted accordingly, regardless of dismissals of the practice by a people whose significantly younger belief-system was based around faith in a man who walked on water and turned it into wine..$^{73}$ It is far easier to dismiss the beliefs of others than to attempt to understand them.

Much European 'evidence' for supposed Aboriginal cannibalism came from Aboriginal allegations that other language groups practised anthropophagy. These Aboriginal accusations of cannibalism were fuelled by misunderstandings about a number of Aboriginal customs, and were further compounded by the European 'need' to see Aborigines as 'savages'. In March 1839 the Reverend Francis Tuckfield sent 'the foot of a black child, the body of which the blacks of Port Phillip were found eating', to his WMS superiors. While Tuckfield did not observe this alleged cannibalism first hand, he asserted that ' $[t]$ his is one, out of many, of the direct evidences which we have that the poor degraded aboriginal inhabitants of Australia are cannibals, and', he added, echoing word for word his Australian supervisor the Reverend Joseph Orton, 'that of the grossest and most shocking description.' Indicating that this 'evidence' was intended for use in securing support and funds for a WMS Aboriginal mission, Tuckfield concluded '[t]hat this evidence may speak volumes in their behalf among the friends of the missions in England is the prayer of yours. ${ }^{74}$

\footnotetext{
${ }^{73}$ John 6:19 \& John 2:1-10, Holy Bible, KJV

${ }^{74}$ Tuckfield to WMS secs., 13 March 1839, HRV2A, p.115
} 
Three years earlier, Orton had written to the WMS secretaries on Aboriginal cannibalism. 'It is an appalling fact', he asserted,

which is all too well substantiated, that these barbarous creatures, not satisfied with the practice of infanticide, are cannibals, and that of the grossest and most shocking description. Their wandering habits render it inconvenient to carry about their young infants; and it is not unfrequently the case that when a second child is born before the former is able to walk, one or the other is destroyed and eaten by them.

Orton's evidence of infanticide and the cannibalising of children is feeble: his 'own observation on the disparity of years between children of the same parents'. Moreover, this assertion was made in the context of suggesting that the WMS establish and finance a mission to the Aboriginal peoples of Port Phillip. Orton's accusation of cannibalism was thus made to shock and appal the WMS secretaries, thus pressuring them into organising and funding a mission: '[f]rom the information I have acquired, my judgement is, that a Mission should be established among the Aboriginal natives'. His plea concluded: 'I repeat that this Mission demands the Committee's immediate attention, and presents no ordinary claims to the liberality of the Christian public. I shall soon expect favourable returns from the Committee in answer to my communications on this subject. ${ }^{\prime 75}$ Once the WMS had, on Orton's advice, established a mission, Tuckfield sought to secure the continuation of financial aid for the cause (and his livelihood).

Some Aboriginal customs surrounding the remains of the deceased also furthered rumours of cannibalism. 'In the disposal of their dead', Chief Protector Robinson reported in July 1841, 'the Aboriginal tribes have different customs.' 'Some bury', he noted, 'others burn, some leave the bodies to be devoured by wild dogs, others place them on biers or raised framework on

\footnotetext{
${ }^{75}$ Orton to WMS secs., August 1836, Joseph Orton, Aborigines of Australia, London:1836, pp.7-8 \& $10-12$
} 
branches of trees and in cavities of rock ... The ashes of the dead, wrapped in skin, and the bones of the decomposed bodies, are worn as amulets' ${ }^{\prime}{ }^{7}$ Three years later, having observed '[m]uch interesting ceremony in the disposal of their dead', Robinson reported that '[i]n some instances especially when a Chief Man dies, the body is frequently kept Eight or ten days, and carried by the Tribe to the favourite resort of the deceased'. He added that 'the bodies of children are at times kept for an indefinite period'.$^{77}$

The chief protector further observed that Aboriginal 'people wear charms or amulets called by them "parepole," from the fat of the human subject wrapped in opossum or kangaroo skins'. Fuelled by the obsessive European aversion to the practice, observations such as these were extended to imaginings of cannibalism: if remains were displayed, they must have been procured by acts of cannibalism. 'Generally speaking', Robinson claimed, 'the Aboriginal Natives are addicted to cannibalism.' His evidence for such a claim was that he had 'found small strips of human flesh in their bags, and persons lubricated with the fat of the human subject' ${ }^{78}$ This is by no means evidence of the Aboriginal consumption of human flesh; rather it suggests that human fat, like the fat of other animals, played an important role in Aboriginal ceremonial life.

Assistant Protector Sievwright concluded his rejection of claims of Aboriginal cannibalism by noting:

[t]heir old people they do not inter, but consume by fire, and they also preserve by a process of steaming or baking, and smoke drying, portions of the bodies of their enemies, which they are anxious to retain

\footnotetext{
76 Robinson, 28 July 1841, 'In Quest of the Tribes', Clark (ed.), p.116

77 G.A. Robinson, 'George Augustus Robinson's Journey into South-Eastern Australia, 1844', George Mackaness (ed.), JRAHS, 27:5, 1941, p.333

78 Robinson, 3 August 1841, 'In Quest of the Tribes', Clark (ed.), p.118
} 
and preserve as long as possible as trophies of victory, or rather revenge, and their greatest pride and desire seems to be to procure the Fat of their enemies with which they grease and keep in repair their spears and other weapons. ${ }^{79}$

The keeping of parts of the bodies of Elders, children, and enemies and the ceremonial use of human fat furthered rumours of cannibalism, as revolted Europeans assumed the flesh and fat mourning or victorious Aborigines carried was for consumption.

Within his discussion of the denoting of Aboriginal 'savagery' by claims of infanticide and cannibalism, Richard Broome notes that firstly, Aboriginal infanticide was not as common as was suggested by Europeans; and secondly, that while Europeans claimed Aboriginal infanticide signified 'savagery', infanticide was practised in European society, where the perpetrators were portrayed as misguided victims. ${ }^{80}$ Russell, who also argues that reports of Aboriginal infanticide were exaggerated, further suggests that a discussion of Aboriginal infanticide needs to be conducted within a framework which acknowledges the history of the European denigration of Aboriginal motherhood..$^{81}$

Stanner was informed that Aborigines conceived children, not through 'physical congress', but rather that an Aboriginal man's spirit, through dreaming of a spirit child, directed the child to his wife, who then con-

\footnotetext{
79 Sievwright, 'Quarterly Report from 1 September to 30 November 1840', cited in Lindsey Arkley, The Hated Protector: the Story of Charles Wightman Sievwright, Protector of Aborigines 1839-42, Melbourne:2000, p.110

${ }^{80}$ Richard Broome, Aboriginal Victorians: a History Since 1800, Sydney:2005, pp.63-64; see also: Ann R. Higginbotham, "Sin of the Age": Infanticide and Illegitimacy in Victorian London', Victorian Studies, 32:3, 1989, pp.319-337; Aeron Hunt, 'Calculations and Concealments: Infanticide in MidNineteenth Century Britain', Victorian Literature and Culture, 34:1, 2006, pp.71-94; R. Sauer, 'Infanticide and Abortion in Nineteenth-Century Britain', Population Studies, 32:1, 1978, pp.81-93; David E. Stannard, 'Recounting the Fables of Savagery: Native Infanticide and the Functions of Political Myth', Journal of American Studies, 25:3, 1991, pp.381-417

${ }^{81}$ Russell, 'Dirty Domestics and Worse Cooks', pp.31-32
} 
ceived. ${ }^{82}$ Europeans, most of whom believed in a miraculous conception of the son of their god in a virgin, were quick to dismiss Aboriginal beliefs surrounding conception, pregnancy, childbirth, and the raising of children. ${ }^{83}$ The first Englishwoman to become pregnant to a Māori man reportedly asked whether the baby would be born with tā moko (tattoo), yet it would be a stretch to draw sweeping statements about European beliefs regarding conception, pregnancy, and childbirth based on such reports. ${ }^{84}$ European misunderstandings about, dismissals of, and aversion to Aboriginal practices such as infanticide were, in certain circumstances, extended to the anthropophagy of infants based upon the mere horror at the thought of this, and the 'requirement' that Aboriginal peoples be shown to be 'savages'.

Broome writes that pre-contact Aboriginal violence was usually sparked by marriage arrangements, adultery, ceremonial disputes, or sorcery. ${ }^{85}$ Thomas observed that the language groups of Port Phillip who were not at enmity with one another 'generally once a year at least unitedly assemble'. 'There are many disputes, imaginary or real, to settle', he noted, 'which cannot be done without some fighting' ${ }^{86}$ It was in this manner that the assistant protector witnessed a clash between the Wathaurong and the Boonwurrung at North Melbourne in December 1844. He reported that a heated argument, during which it was established that the Wathaurong had accused the Boonwurrung of killing two of their group and stealing a number of women, was followed by a ritualised fight in which many spears were thrown, al-

\footnotetext{
82 W.E.H. Stanner, White Man Got No Dreaming: Essays, 1938-1973, Canberra:1979, pp.25-27

${ }^{83}$ Luke 1:26-35, Holy Bible, KJV

${ }^{84}$ O'Malley, p.55

${ }^{85}$ Broome, Aboriginal Australians, p.18

${ }^{86}$ Thomas, 'Brief Account', p.401
} 
ways with care. The conflict resulted in only a few wounds and peace was then restored by a concluding ceremony. Thomas reported: '[t]hey seldom do much execution in their fights - a few wonguim [boomerang] and spear wounds in some not dangerous parts of the body' ${ }^{87}$

The Aboriginal custom of resolving disputes by organised fights was wellknown among early settlers. In October 1803 the death of an Aboriginal man was reported in the Sydney Gazette. He died 'in consequence of two wounds in the body from jagged spears, which he received in punishment, as being related to the man by whose hand one of another family was accidently slain'. 'Ten spears were thrown at him', the report continued, 'five at a time, one of which at each flight pierced his body.' By conveniently ignoring that Aboriginal peoples had survived (and thrived) prior to European contact, this regulated internecine violence was frequently blamed for the rapid postcontact depopulation experienced by Aboriginal peoples. The Sydney Gazette article concluded: '[b]y an unconquerable attachment to these barbarous usages, and an utter dislike to civilized customs, this savage race of men are principally intent on the work of depopulation' ${ }^{88}$ This comforting conclusion, that Aborigines were making themselves extinct independent of European actions, removed the guilt of colonisation and the large-scale depopulation which it affected. As Jessie Mitchell observes, '[b]laming Aboriginal people for their own demise was one way of avoiding colonial responsibility $^{\prime}{ }^{89}$

The depiction of Aboriginal peoples as violent 'savages' made European violence against Aborigines, which was often viewed as a necessary factor of

\footnotetext{
87 ibid., pp.430-433; see also: A.W. Howitt, 'Notes on Australian Message Sticks and Messengers', JAIGBI, 18, 1889, p.316n

88 Sydney Gazette and New South Wales Advertiser, 2 October 1803, p.2

89 Jessie Mitchell, 'Flesh, Dreams and Spirit: Life on Aboriginal Mission Stations, 1825-1850, a History of Cross-Cultural Connections', PhD thesis, Australian National University:2005, p.302
} 
colonisation, easier for Europeans to justify among themselves. 'No man, who comes to this Colony and has ground and cattle and Corn', London Missionary Society (LMS) missionary the Reverend Lancelot Edward Threlkeld observed of New South Wales in 1826, 'can dispassionately view the subject of the blacks, their interest says annihilate the race. ${ }^{90} \mathrm{He}$ added twelve years later: '[i]f sophistry and world philosophy could but succeed' in persuading people that the Black inhabitants of the Colonies are merely Brutes, without reasoning faculties, and incapable of instruction, the natural consequence would be that to shoot them dead would be no more a moral evil, than the destroying of rats by poison, or of the Ourang Outang by the fusee! $!^{91}$

In 1844 a correspondent to the Colonial Literary Journal, writing under the pseudonym 'Aneas', linked phrenology with Aboriginal violence. 'The Aboriginal cranium appears to be large', the writer suggested, 'although in reality the brain is not so. The uncommon thickness of the skull and in the integuments surrounding it, accounts for this; and the strength of the Aboriginal head-piece in resisting the most powerful blows of their waddy is well known.' Aboriginal peoples' heads seemed 'to be their invulnerable part, and a stroke upon it, has as little influence as upon a block of wood'. The writer asserted: '[p]roverbial expressions have had their origin in common sense, and the epithets thick-head, block-head, have been bestowed with a considerable degree of point and shrewdness'. 'The great proponderancy of the brain in the New Hollander', the writer concluded, 'as in all savage nations, lies in the posterior parts of the head - the seat of the passions, and inferior sentiments; the moral and intellectual portions, with few exceptions, are very

\footnotetext{
90 Threlkeld to LMS secs., 10 August 1826, L.E. Threlkeld, Australian Reminiscences \& Papers of L.E. Threlkeld, Missionary to the Aborigines, 1824-1859, Niel Gunson (ed.), 2 vols., Canberra:1974, ii:pp.212-213

91 Threlkeld, 'Annual Report of the Mission to the Aborigines', 31 December 1838, Australian Reminiscences, i:p.147
} 
deficient. ${ }^{92}$ Not only were Aboriginal peoples supposed to have thick skulls, able to sustain significant blows to the head, they purportedly had an inferior brain capacity, the majority of which was allegedly devoted to the seat of the passions', inferring that this was the cause of Aboriginal violence.

Threlkeld, who was strongly opposed to the pseudoscience of phrenology, further noted that 'it was maintained by many in the colony that the Blacks had no language at all but were only a race of the monkey tribe!' 'This was a convenient assumption', the evangelical concluded, 'for if it could be proved that the Aborigines of New South Wales were only a species of wild beasts, there could be no guilt attributed to those who shot them off or poisoned them as cumberers of the earth. ${ }^{93}$ European misunderstandings about and dismissals of Aboriginal beliefs and customs surrounding sorcery, revenge killings, and ritualised violent conflict resolution fed portrayals of Aborigines as violent 'savages', which served as a justification for the violent European invasion of the continent.

Daisy May Bates, who wrote in the early-twentieth century about Aboriginal peoples of western, southern, and central Australia, was perhaps the most influential writer on Aboriginal cannibalism. Bates' allegations of Aboriginal cannibalism were the culmination of a long-standing rhetoric about Aboriginal 'savagery' and cannibalism. As such, although she falls outside the timeframe of the focus of this thesis and her encounters lie slightly beyond the margins of its geography, her accusations of Aboriginal cannibalism are here

\footnotetext{
92 Colonial Literary Journal, 29 August \& 5 September 1844, cited in Reynolds, Dispossession, p.108

93 Threlkeld, 'Reminiscences of the Aborigines of New South Wales', Australian Reminiscences, i:p.46
} 
briefly examined in exploring the development of, and reasons behind, the conceptualisation of Aboriginal cannibalistic violence.

In the early years of the twentieth century Bates spent several years visiting and living with various Aboriginal peoples of the Kimberley and the Australian southwest. In 1912 she moved to Eucla, situated between the Nullarbor Plain and the Great Australian Bight, in Mirning country, eight miles west of the Western Australia-South Australia border. In the spring of 1919 Bates moved to Ooldea, a waterhole in South Australia alongside which passed the trans-Australian railway, at the junction of Mirning country, Wirangu country, Kokatha country, and Ngalea country. Here she spent sixteen years living with, and writing about, Aboriginal peoples who gathered from across southern and central Australia. ${ }^{94}$

Bates, contemporaneously identified as 'the solitary spectator of a vanishing race', ${ }^{95}$ published in 1938 her Passing of the Aborigines: a Lifetime Spent among the Natives of Australia. The book was drawn from her earlier autobiographical 'My Natives and I', which had been serialised in a number of leading Australian newspapers. ${ }^{96}$ Alan Moorehead suggested Bates knew the Aborigines better than they knew themselves. ${ }^{97}$ Biographer Bob Reece asserts that Bates' 'Passing of the Aborigines was one of the most influential books ever to be published in the English language'.$^{98}$ Richard Hall is more re-

\footnotetext{
94 Bob Reece, Daisy Bates: Grand Dame of the Desert, Canberra:2007, pp.13-43; Hall, pp.149-154; R.V.S Wright, 'Bates, Daisy May (1863-1951), Australian Dictionary of Biography (ADB), online edition; Daisy Bates, The Passing of the Aborigines: a Lifetime Spent among the Natives of Australia [1938], second edition London:1966, p.190; Bob Reece, “Killing with kindness": Daisy Bates and New Norcia', $A H, 32,2008$, p.128; Jim Anderson, "A glorious thing is to live in a tent in the infinite": Daisy Bates', in Anna Cole et al. (eds.), Uncommon Ground: White Women in Aboriginal History, Canberra:2005, pp.217-231

95 Arthur Mee, 'Introduction', in Bates, Passing, p.xi

96 Reece, Daisy Bates, p.120

97 '[S] he knew them better than anyone else who has ever lived'; Alan Moorehead, 'Foreword', in Bates, Passing, p.ix

98 Reece, Daisy Bates, p.124
} 
strained, but still argues that 'Bates did more than any other person to form Australian public opinion about Aborigines' in the first sixty-odd years of the twentieth century. ${ }^{99}$

Bates constructed her texts so as to generate shock and horror in her readers. Furthermore, she became obsessed with the idea of Aboriginal cannibalism, writing of it frequently, in part to emphasise Aboriginal 'savagery', and in part to enthral her readers. As Reece observes of the effect of her published articles accusing Aborigines of cannibalism, they 'were to shock her readers, delight her editors and horrify the anthropological and humanitarian fraternities for years to come' ${ }^{100}$ Her evidence of Aboriginal cannibalism was, however, highly problematic.

Like that of her nineteenth-century predecessors, Bates' alleged evidence of Aboriginal cannibalism was sometimes volunteered to her by Aboriginal peoples themselves. Writing of Aborigines among whom she lived at Eucla, Bates asserted: they 'frankly admitted the hunting and sharing of ... human meat as frequently as that of kangaroo and emu'. Bates wrote that one group 'drank the blood of those they had killed', while another 'were a fierce arrogant tribe who pursued fat men, women and girls'. 'Another group would cut off hand and foot, and partake of these first, to prevent the ghost from following and spearing them spiritually' ${ }^{101}$ Of the Aboriginal peoples of the Dampier Peninsula, in the Kimberley, Bates claimed that ' $[t]$ he women quite frankly admitted to me that they had killed and eaten some of their children - they liked "baby meat".'102

\footnotetext{
99 Hall, pp.5-6

100 Reece, Daisy Bates, p.86

101 Bates, Passing, p.122

102 ibid., p.11
} 
As noted above, such Aboriginal 'confessions' of cannibalism must be treated with caution. In a Dreaming story shared with Bates an exasperated Ngangaru, the sun, told her nagging children, who were demanding they be allowed to eat the food she had collected for their father Meeka, the moon: 'I'll tie up your heads and cook you for your father to eat as well'. ${ }^{103} \mathrm{Al}$ though this was a tale told to children to remind them to behave, Bates took the fable as evidence of cannibalism. Other Dreaming stories told to Bates explicitly contradict infant cannibalism; the tale of the Janga Yonggar and the Karnding, the spirit kangaroo and the bush mice, is a lesson not to eat one's own children. ${ }^{104}$ Yet Bates overlooked the moral of this tale, instead seeing a tongue-in-cheek threat as evidence of that which she sought, Aboriginal cannibalism. As Dan Beaver suggests, just as indigenous accounts of cannibalism 'may express myth and metaphor', European accounts 'may reflect merely their assumptions, prejudices, fantasies' ${ }^{\prime}{ }^{105}$

'As to the subject of cannibalism which has been attributed to them', reported Assistant Protector Sievwright in 1840, 'I have in no instance met with it'. 'In order to amuse', he continued, 'I have heard the women and young men repeat such fables, as such anecdotes are generally sought for, and received with much avidity by the white population.' ${ }^{106}$ Yet Bates declared she used the term cannibal 'advisedly'. 'Every one of these central natives was a cannibal', she claimed. 'Human meat had always been their favourite food, and there were killing vendettas from time immemorial'. 'Every one of the natives whom I encountered on the east-west [railway] line had partaken of human meat', she continued, adding that ' $[t]$ hey freely admit their sharing of

\footnotetext{
103 Daisy Bates, Tales Told to Kabbarli: Aboriginal Legends Collected by Daisy Bates, Barbara Ker Wilson (ed.), London:1972, p.15

104 ibid., pp.35-37

105 Dan Beaver, '[Review Essay] Flesh or Fantasy: Cannibalism and the Meanings of Violence', Ethnohistory, 49:3, 2002, p.671

106 Sievwright, 'Quarterly Report from 1 September to 30 November 1840', cited in Arkley, pp.109-110
} 
these repasts'. 'My first words to them were always "No more man-meat." From the weekly supply train, I would procure part of a bullock or sheep and show them they game food areas, mallee-hen's eggs, rabbits and so on, that must be their meats now, with as many dampers as I could provide, and a drink of sweetened tea'.$^{107}$

That Bates' first words to Aborigines whom she encountered were always 'no more man-meat' is important, not least in light of the Aboriginal tendency to respond to European questions or comments in a positive manner. Moreover, when first meeting Aborigines Bates asked them if they ate human flesh - having presumably already inculcated them of her 'no more man-meat' doctrine - and insisted they instead eat food she suggested and provided, it is not at all surprising that Aborigines responded in the affirmative, if only simply to secure complimentary meat, damper, sugar, and tea. Evincing their reasons for tolerating being instructed on how to think and act, the Nyul Nyul, Bates' initial Aboriginal contacts, told the 'Hail Marys' - their name for the Trappist monks whose presence they tolerated - 'no more tobacco, no more h'Allelulia'. ${ }^{108}$

Similarly, Bates often asked the Aboriginal peoples who travelled to live near her at Ooldea why they did not return to country.

"No," they said, "we can't go back, we would be stalked and killed by the relations of those we killed and ate on our way to Ooldea Water. We are safe here with you, but if we went back we would kill and eat our own people again, and when those whose brothers and fathers were killed and ate came to Yooldil gabba, you 'look out' Kabbarli, and you don't let them eat us or let us eat them and so we can all sit

\footnotetext{
107 Bates, Passing, pp.195-196

108 Broome, Aboriginal Australians, p.102; Reynolds, Other Side of the Frontier, p.189
} 
down with you, but in our own country we must kill and eat our own kind, beegaringu (faction fighting) always." 109

This line of questioning was apparently interpreted by Aborigines as a threat to forcibly remove them from 'her' camp, and to stop feeding and clothing them and providing them with tobacco. One way for them to guard against this was to suggest that a return to country was not only life-threatening for them, but that it would also necessitate a return to what horrified her most, as judged by her persistent enquiries about and reactions to it - cannibalism.

In enquiring into Aboriginal peoples' customs and beliefs, Bates used leading questions. During her time among the Nyul Nyul and other peoples of the Kimberley she claimed '[n]ot a word nor a gesture passed me without opening up an avenue of inquiry, tactfully and methodically pursued.'110 This points to her use of questions which overtly conveyed the answers she sought. Aborigines are known to have responded to the enquirer in a positive manner, which was often misinterpreted by Europeans as correct and truthful answers. ${ }^{111}$ As Bates herself acknowledged: '[t]he Australian follows the line of least resistance with the white man. He will always respond as desired to a leading question, eager to please, whether he understands it or not.'112 She also wrote of 'parrot repetition, in which they excel'. ${ }^{113}$ Despite her confessed knowledge of such important customs, Bates' writings, particularly her accusations of cannibalism, portray little evidence of her having applied such understanding of Aboriginal rhetoric to her own enquiries. Dreaming stories further tell of the scornful mimicking of foreign languages,

\footnotetext{
109 Bates, Passing, pp.229-230, italics in original

110 ibid., p.23

111 One tangible example of this is Kurnai responses to European enquiries regarding the 'captive white woman' of Gippsland, discussed in chapter three; see for example: Melbourne Argus, 26 January 1847, p.4

112 Bates, Passing, p.105; Bob Reece, 'AP Elkin Interviewed about Daisy Bates', Australian Aboriginal Studies, 1, 2007, pp.135-136

113 Bates, Passing, p.155
} 
a practice likely to have influenced Aborigines' exchanges with Bates' and other Europeans'. ${ }^{114}$

The culmination of a century of discourse on 'savagery', Bates' writings on Aboriginal peoples had an immense influence on how they were, and continue to be, perceived by Europeans. Her accusation of Aboriginal cannibalism served to horrify and fascinate her audience and to strengthen the notion that Aborigines were violent 'savages', who occupied the lowest rung on the Europeans' hierarchy of races, and who were doomed to extinction, thus clearing the conscience of European settlers. A recent example of the purpose served by labelling Aborigines cannibals occurred with the 1997 publication of Pauline Hanson's The Truth. Hanson, who was at the time of the publication a high-profile Member of Parliament for the seat of Oxley, accuses Aboriginal peoples of cannibalism, particularly infant cannibalism, citing Bates' accusations as evidence. Aboriginal cannibalism, Hanson argues, 'refutes the romantic view of the Aborigines' and averts the 'guilt' associated with claims of invasion and genocide. ${ }^{115}$ Accusations of Aboriginal 'savagery' continue to be used in attempts to justify colonisation.

European settlers arrived in Australia in the late-eighteenth and earlynineteenth centuries with a simultaneous fear of and fascination with cannibalism, which prompted them to actively seek instances of Aboriginal anthropophagy. The incessant questioning of Aboriginal peoples about cannibalism - by colonial officials, evangelicals, and other settlers - caused by this

\footnotetext{
114 Bates, Tales Told to Kabbarli, pp.32-34

115 Pauline Hanson, The Truth: on Asian Immigration, the Aboriginal Question, the Gun Debate and the Future of Australia, Brisbane:1997, pp.131-135; Biber, p.626; Reece, Daisy Bates, p.2; Hall, pp.5-7, 147-170 \& 206
} 
enthralment, led to rumours of Aboriginal cannibalism beginning soon after first settlement. Aboriginal peoples thought of, and referred to, unknown Aboriginal groups as 'wild blacks', who were to be feared. Upon learning of the European utter aversion to cannibalism, Aborigines told Europeans that 'wild blacks' and their traditional neighbouring enemies were anthropophagi, attempting to communicate their fear of their known enemies and unknown Aborigines to the newcomers in a manner they felt the Europeans could understand.

These Aboriginal 'accusations' of cannibalism were supplemented by European reports of the practice, which were rarely claimed to be eyewitness, and were often the product of misunderstandings about cremation and the Aboriginal practice of the removal of kidney fat, or the carrying with them portions of the bodies of the deceased. This confusion was further compounded by the Europeans' 'need' to see Aboriginal peoples as cannibals: philanthropists claimed existing cannibalism to identify and maintain Aboriginal 'savagery' in order to ensure funding, and declared former Aboriginal cannibalism to signify evangelical success; settlers alleged Aboriginal cannibalism to indicate 'savagery' and thus 'justify' colonisation.

European constructions of Aboriginal inter-gender violence also served to depict Aborigines as 'savages', thus justifying colonisation. Depictions of Aboriginal violence dominated European writings on Aborigines. Like their conceptualisations of other forms of Aboriginal violence, particularly infanticide and inter-gender violence, Europeans constructed an image of Aborigines as cannibals to portray a people who were violent 'savages'. Empirically, the conceptualisation of Aboriginal peoples as violent shows the European construction of a people to be feared. Indeed this fear permeated colonial society; European perceptions (and imaginings) of internecine Aboriginal 
violence were applied to apprehensions about Aboriginal-European violence. A more analytical examination further demonstrates an additional anodyne purpose to the conceptualisation of Aboriginal violence. Europeans constructed the Aboriginal peoples of Australia as violent, cannibal 'savages', portraying a people fit for colonisation, 'civilisation', and Christianisation, in effect to justify and expunge guilt from their own violent invasion of the continent, be it for penal, pastoral, or preaching purposes. 


\section{Chapter Two \\ '[A] most warlike people': the Conceptualisation of Mãori Violence}

The day prior to departing New Zealand, having spent six months circumnavigating the islands during 1769 and 1770, Banks spent 'a few sheets in drawing together what I have observd of this countrey and its inhabitants'. Of Māori, the English gentleman-botanist noted ' $[\mathrm{t}]$ he dispositions of Both Sexes seems mild, gentle, and very affectionate to each other but implacable towards their enemies, who after having killd they eat, probably out of a princpal of revenge'. 'They seem', he concluded, 'innurd to war'. ${ }^{1}$ Nearly a century-and-a-half later, religious historian John Blacket asserted that New Zealand was, at the time of Banks' encounter, 'inhabited by a warlike and revengeful race of natives'. Māori were, Blacket wrote, 'men and women of fine physique, with some virtues and many vices. Polygamy and slavery were common amongst them; they were also guilty of infanticide; and cannibalism, in its most revolting forms, was universal. ${ }^{2}$

Contemporaneously, Best wrote that Māori - who 'ever looked to the battlefield for his death-bed' - 'constituted a most warlike people when visited by early European voyages'. ${ }^{3}$ Being identified as a most warlike people necessitated comparison with other peoples, and this is what both early visitors and initial settlers (and later ethnographers and historians) who encountered Māori did. Europeans viewed Māori through their own notions of civility and barbarism, and compared Māori with themselves and with other nonEuropean peoples. This European conceptualisation of Māori as 'most war-

\footnotetext{
1 Banks, 'Account of New Zealand', Journal, 30 March 1770, ii:pp.1 \& 12

2 John Blacket, Missionary Triumphs Among the Settlers in Australia and the Savages of the South Seas, London:1914, p.63

${ }^{3}$ Elsdon Best, 'Notes on the Art of War, as Conducted by the Maori of New Zealand [Part I]', Journal of the Polynesian Society (JPS), 11:1, 1902, pp.31 \& 13
} 
like' was further encouraged by Māori themselves. Māori were quick to manipulate European perceptions of them upon learning of the Europeans' simultaneous fear of and fascination with Māori practices involving violence, particularly cannibalism.

Christina Thompson asserts that during the initial contact period 'the Maori Warrior is typically admired by visiting Europeans'. ${ }^{4}$ In contrast to this, through an examination of the early-contact conceptualisation of Māori internecine violence, particularly cannibalism but also infanticide and warfare, it is here argued that the initial perception of Māori was not 'typically' one of admiration. Rather, the European conceptualisation of Māori violence, as revealed through the writings of early explorers and initial settlers, particularly missionaries, involved a complex mix of fear, fascination, and revulsion, as well as admiration. This conceptualisation of Māori violence, which culminated in the construction of Māori as 'most warlike', is here examined to explore how simultaneously positive and negative images of Māori violence influenced the superior place assigned to Māori on the Europeans' hierarchy of races, near, if not at, the top of all indigenous peoples.

In this chapter it is argued that, overarchingly, Europeans initially envisioned Māori as 'most warlike'. While other aspects of Māori society were reported on by early explorers and initial settlers, violence dominated European depictions of Māori society. It is further argued that the European conceptualisation of Māori violence was multifarious and even contradictory: perceived negative aspects of Māori violence, while dominating much rhetoric about Māori, were overlooked in the largely positive envisioning of Māori as among the highest 'savage' peoples on the Europeans' hierarchy of races.

\footnotetext{
${ }^{4}$ Christina A. Thompson, 'A Dangerous People Whose Only Occupation is War: Maori and Pakeha in 19th-Century New Zealand', JPH, 32:1, 1997, p.114
} 
It is also here argued that Māori agency played a vital role in this conceptualisation, as Māori quickly learned of the Europeans' simultaneous admiration for, yet aversion to, certain aspects of their traditional violent behaviours, and sought to both reinforce and exploit the European image of them as 'most warlike'.

Cook's contact with Māori has been much-discussed by New Zealand historians. The early missionaries, too, have received their fair share of attention. The complex conceptualisation of Māori violence as both positive and negative has, however, been given much less attention. It is analysis of this European conceptualisation of Māori violence, and how this compared with the conceptualisation of Aboriginal violence and their inferior assigned place on the Europeans' hierarchy of races, together with a particular focus on Māori agency in this conceptualisation, which is the key contribution of this chapter.

The late-eighteenth and early-nineteenth centuries were a period when European racial thinking was in a particularly transformative stage, and this had considerable influence on the conceptualisation of Māori (and Aboriginal) violence. In discussing race in nineteenth-century Scottish nationhood, Colin Kidd notes that '[r]ace had multiple, imprecise and overlapping definitions' during this period. 'In some cases race was used as a convenient synonym for nationality; but, more commonly, it referred to a broader category of ethnicity, sometimes to physical types, sometimes to linguistic communities, or to groups which were defined both by physical characteristics and a common speech. ${ }^{5}$ Kidd argues that while ' $[t]$ he Enlightenment did

\footnotetext{
${ }^{5}$ Colin Kidd, 'Race, Empire, and the Limits of Nineteenth-Century Scottish Nationhood', Historical Journal, 46:4, 2003, p.877
} 
give birth to a de-Christianised form of scientific racism' which did not allow for 'civilising' 'savages', the moderate form of Enlightenment taught in and dispersed from Scottish universities was 'recycled as a sustaining ideology for Christian missions'. All the peoples of the world, leading Enlightenment philosophers proclaimed, shared the potential for improvement. ${ }^{6}$

In exploring the changing meanings of the terms 'nation', 'tribe', and 'race' during the period from the Renaissance to the Enlightenment, Nicholas Hudson argues that although European explorers certainly perceived themselves as superior to non-European peoples they encountered, this perceived supremacy was not founded on racial hierarchy, but on the belief that Europeans had attained a level of 'civilisation' unknown to others. ${ }^{7}$ Beginning with Cook's Enlightenment-influenced encounters with Pacific peoples, European writings on Māori, Aborigines, and other indigenous peoples, and the images these created, were used to construct a racial hierarchy which was largely based on perceived similarities and differences with the European concept of 'civilisation'. Thus although European concepts of race were changing during this period - the twilight of the Enlightenment - lateeighteenth- and early-nineteenth-century Europeans' perceived supremacy and racial hierarchy were inextricably linked with European encounters with the indigenous peoples of the Tasman world.

Bronwen Douglas has highlighted the 'complacent Western assumption that Polynesians are superior to Melanesians and Aborigines'. This perceived supremacy, as Douglas notes, was based upon the belief that Polynesian peoples 'are aesthetically more pleasing, and because their (more familiar)

\footnotetext{
${ }^{6}$ Colin Kidd, The Forging of Races: Race and Scripture in the Protestant Atlantic World, 1600-2000, Cambridge:2006, p.120

7 Nicholas Hudson, 'From "Nation" to "Race": the Origin of Racial Classification in EighteenthCentury Thought', Eighteenth-Century Studies, 29:3, 1996, pp.248-250
} 
social organization, customs and demeanour were deemed more "advanced"'. .8 The late-eighteenth- and early-nineteenth-century conceptualisation of indigenous violence played a key part in this racial hierarchism.

Perhaps the most vivid aspect of the European conceptualisation of Māori as warlike was European perceptions of the Māori custom of kaitangata - cannibalism. Here the aim is not to question Māori cannibalism. As Te Maire Tau observes in questioning whether Paul Moon's This Horrid Practice is unnecessary - 'a bit silly' - 'Māori ate people and we say so and even celebrate it in our songs and oral traditions. ${ }^{9}$ As Tau suggests, seeking to prove Māori cannibalism is unnecessary, for Māori themselves do not deny the historical practice.

Moon, for his part, writing from a self-proclaimed 'more enlightened modern perspective' than the Māori of whom he writes, sees cannibalism as 'evil' - aligning the practice with bestiality, paedophilia, and the Holocaust though he sees hunger-driven (European) cannibalism as less 'evil' than other, less 'humanitarian', motives for anthropophagy. 'Maori society and culture were', for Moon, 'better off, more vigorous and more self-valuing by dispensing with cannibalism than by clinging to the practice'. He sees European intervention as merely speeding up the inevitable Māori abandonment of kaitangata. Moreover, comparing tikanga (custom) with European prac-

\footnotetext{
8 Bronwen Douglas, 'Science and the Art of Representing "Savages": Reading "Race" in Text and Image in South Seas Voyage Literature', History and Anthropology, 11:2-3, 1999, p.161; Douglas has explored Oceanic hierarchism in a number of works: Bronwen Douglas, 'Voyages, Encounters, and Agency in Oceania: Captain Cook and Indigenous People', History Compass, 6:3, 2008, pp.712-737; Bronwen Douglas, 'Notes on "Race" and the Biologisation of Human Difference', JPH, 40:3, 2005, pp.331-338; Bronwen Douglas, 'The Lure of Texts and the Discipline of Praxis: Cross-Cultural History in a Post-Empirical World', Humanities Research, 14:1, 2007, pp.11-30; Bronwen Douglas, 'Seaborne Ethnography and the Natural History of Man', JPH, 38:1, 2003, pp.3-27; Bronwen Douglas, 'Slippery Word, Ambiguous Praxis: "Race" and Late-18th-Century Voyagers in Oceania', JPH, 41:1, 2006, pp.129

9 Te Maire Tau, '[Review of] Paul Moon, This Horrid Practice', Te Pouhere Korero, 3, 2009, p.124
} 
tices, Moon sees a paradox between tangi (funerals) and kaitangata: '[y]et, for all this cocktail of compassion, sympathy, and lamentation, the same people who allowed their emotions to be churned at tangi were evidently also prepared to eat dead people'. '[H]ow', he asks, 'could this feeling towards death be turned off, like a tap, when it suited the murderous cannibalistic urges of some members of the community?'10 The answer would clearly be that tangi were for whānau, for hapū; kaitangata was for enemies. But any answer is superfluous, for the question is ethnocentric: why should Māori have had (or still have) to maintain what Europeans deemed to be consistent beliefs and customs concerning death?

In Māori society, the victims of cannibalism were the enemies of the perpetrators. Hanson and Hanson note that for Māori, cannibalism was part of a wider subjugation of defeated enemies. Vanquished opponents were generally either enslaved or killed. Those killed were not only sometimes partially consumed, but also faced the degradation of having their bones used as tools and/or their heads dried, cured, displayed, and taunted. ${ }^{11}$ As former SubProtector of Aborigines Edward Shortland wrote, ‘[t]o eat an enemy was the greatest degradation to which he could be subjected'. ${ }^{12}$ 'Eating an enemy', Ranginui Walker further notes, 'was more than a symbolic ingestion of mana [prestige]. It was the ultimate debasement to be passed through the alimentary canal and emerge as excrement.'13 The consumption of one's enemies was a normal aspect of Māori warfare.

\footnotetext{
10 Paul Moon, This Horrid Practice: the Myth and Reality of Traditional Maori Cannibalism, Auckland:2008, pp.173, 14, 12, 132, 176 \& 124-125

${ }^{11}$ F. Allan Hanson and Louise Hanson, Counterpoint in Maori Culture, London:1983, pp.169-178; Belich, Making Peoples, p.78; Ormond Wilson, From Hongi Hika to Hone Heke: a Quarter Century of Upheaval, Dunedin:1985, pp.158-166; A.P. Vayda, Maori Warfare, Wellington:1960, pp.94-97

12 Edward Shortland, Maori Religion and Mythology, London:1882, p.26

13 Ranginui Walker, Ka Whawhai Tonu Matou: Struggle Without End [1990], second edition Auckland:2004, p.72
} 
Obeyesekere dismisses the construction of Māori 'anthropophagycannibalism' using 'interviews with older men, myths, missionary and magistrate accounts, and even that of eyewitnesses' as 'extremely dubious, since the practice might itself have been affected by the evolving discourse' ${ }^{14}$ This suggestion that any attempt to understand Māori cannibalism is 'dubious' is also here rejected. Instead, Māori agency within the European conceptualisation of the practice is examined in an attempt to understand European interpretations of Māori cannibalism, including through the Māori manipulation of these interpretations.

Much of the historiography dealing with Māori cannibalism is centred on the consumption of ten European sailors from the Adventure at Whareunga (Grass Cove) during Cook's second Pacific voyage. During his first visit to New Zealand Cook had determined Māori were anthropophagi. This information was, however, often met with disbelief upon its circulation following the Endeavour's return to Britain in 1771. Cook later wrote: 'the account I gave of it in my former Voyage was partly founded on circumstances and was, as I afterwards found, discredited by many people. I have often been asked, after relating all the circumstance, if I had actualy seen them eat human flesh my self' ${ }^{15}$ Cook, therefore, sought further evidence of Māori cannibalism on his subsequent visits to New Zealand. As Polack later noted, '[w]hile at anchor in the Sound, the Englishmen had the most unquestionable proofs of the cannibal propensities of the natives.' ${ }^{\prime 6}$

Obeyesekere is concerned with how the arrival of Europeans changed Māori cannibalism. The 'event in Grass Cove can only partially illuminate Maori anthropophagy because', he writes, with admittedly indisputable logic,

\footnotetext{
14 Obeyesekere, Cannibal Talk, p.57

15 Cook, Journal, 23 November 1773, ii:p.294

16 Polack, New Zealand, i:p.38
} 
'prior to the coming of the Europeans ... Maori could not possibly have consumed Europeans'. He further suggests that this 'change in Maori anthropophagous habits and proclivities must be incorporated into our knowledge of Maori cannibalism'. 'It is unlikely', he concludes, 'that the Maori simply fitted the British into their preexistent cultural forms and treated them as if they were traditional tribal enemies, because the British were not their traditional enemies' ${ }^{17}$ That a change in traditional kaitangata occurred is certain; where European victims fitted into the Māori custom is, however, disputed.

In contrast to Obeyesekere, Salmond suggests that at Whareunga the European victims became the enemies of local Māori for traditional reasons. She argues that it was an incident aboard the Resolution a month earlier, in which Lieutenant Charles Clerke cooked part of a dead Māori man's cheek and fed it to a Māori visitor from another part of the sound, which led to the ten Adventure crewmen being killed and consumed. Further evincing Māori agency in their conceptualisation as warlike cannibal 'savages', the Māori visitor ate the flesh with exaggerated relish for the Europeans' benefit. This was remembered by the dead man's hapū who, Salmond argues, exacted utu (reciprocity) on the Adventure crew a month later. ${ }^{18}$ Cook later hosted Kahura, the rangatira believed responsible for the utu exacted at Whareunga, aboard the Resolution on his third Pacific voyage; his failure to secure utu in return led to a considerable loss of mana in both European and Māori eyes. ${ }^{19}$

\footnotetext{
17 Obeyesekere, Cannibal Talk, p.59, emphasis in original

18 Writing a century earlier, George Clarke (junior) suggested - based on 'the story from a very old man' - that the breach of tapu which occasioned the Whareunga incident was a European sailor putting a tin which had contained food on the head of a rangatira; George Clarke (junior), Notes on Early Life in New Zealand, Hobart:1903, p.27; Salmond, Trial, pp.223-231; Obeyesekere, 'British Cannibals', p.637-638; Thomas, Discoveries, pp.209-215; see also: George Forster, A Voyage Round the World [1777], 23 November 1773, Nicholas Thomas and Oliver Berghof (eds.), 2 vols., Honolulu:2000, i:pp.276-282

${ }^{19}$ Cook, Journal, 11-25 February 1777, iii part 1:pp.59-75; Salmond, Trial, pp.312-317; Salmond, Aphrodite's Island, pp.404-405
} 
This extension of internecine Māori cannibalism at Whareunga is important; it both solidified the European image of Māori as 'most warlike' and justified the pervasive fear that Māori violence could be extended to Māori-European violence. Prior to this 'confirmation' of Māori cannibalism, however, there had been much discourse on the subject.

On 9 October 1769, at Tūranga-nui (Poverty Bay), crew from the Endeavour set foot on the New Zealand shore; they were the first Europeans to do so. The following day the European visitors kidnapped three Māori males, whom they estimated to be aged eighteen, fifteen, and ten, holding them on board the ship overnight. ${ }^{20}$ Prior to the Endeavour's departure from Britain, President of the Royal Society, the Earl of Morton, had offered Cook, Banks, and 'the other Gentlemen' some 'Hints' for their impending interaction with indigenous peoples. Among these was the suggestion that '[o]pening the mouth wide, putting the fingers towards it, and then making the motion of chewing, would sufficiently demonstrate a want of food' ${ }^{21}$ If, in seeking to procure provisions from these kidnapped Māori, or in asking the terrified youths whether they wanted something to eat, the Endeavour crew employed the suggested mime, as is likely, the Māori hostages may well have fearfully misunderstood the message intended in the Europeans' action of putting their fingers near their mouths and chewing enthusiastically as a threat.

In his 'Account of the Island of Tahiti', written from gaol and detailing his six-month stay on the island in 1789, Bounty mutineer James Morrison reported of Tahitians: 'from our being so fond of Flesh they at First Conceived

\footnotetext{
20 Banks, Journal, 9-10 October 1769, i:pp.400-406

${ }^{21}$ Earl of Morton, 'Hints', Cook, Journal, i:pp.514-519
} 
that We were Cannibals as they have an account of the Inhabitants of an Island to the East of them who eat each other' ${ }^{22}$ Obeyesekere argues that upon first contact in Hawai'i, Hawai'ians 'made the pragmatic inference that these half-starved people [Cook and crew] were asking questions about cannibalism because they were cannibals themselves and might actually eat the Hawaiians'.$^{23}$ This was likely initially the case with Māori too; additionally so because unlike Hawai'ians, Māori did practice cannibalism. As discussed below, tokerau (northern) Māori eagerly enquired whether the French were cannibals at first contact in December 1769. The Endeavour crew fed their hostages bread and, significantly, salted pork. Banks later recalled that the kidnapped Māori mentioned cannibalism 'of their own accords, asking whether the meat they eat was not human flesh' ${ }^{24}$ It was in this context that the Māori hostages informed the European visitors that the People of our side of the Bay eat men'. ${ }^{25}$ This assertion of Māori cannibalism was initially dismissed by the Endeavour crew.

The following day Cook sought to return the hostages to shore, but found that 'they were very unwilling to leave us pretending that they should fall into the hands of their enimies who would kill and eat them' ${ }^{26}$ Banks elaborated: upon seeing that they were to be returned to shore 'the boys express'd much joy at this till they saw that they were going to land at our old Landing place near the river, they beggd very much that they might not be set ashore at that place where they said were Enemies of theirs who would kill and eat them' ${ }^{27}$ Europeans thus first learned of Māori cannibalism through Māori

\footnotetext{
22 James Morrison, 'Account of the Island of Tahiti \& the Customs of the Island', Journal of James Morrison, Boatswain's Mate of the Bounty, Owen Rutter (ed.), London:1935, p.82

${ }^{23}$ Obeyesekere, 'British Cannibals', p.634

24 Banks, Journal, 1 December 1769, i:p.443

25 That is the north side of the bay, where the Europeans had landed; Richard Pickersgill, quoted in Salmond, Two Worlds, p.129

${ }^{26}$ Cook, Journal, 10 October 1769, i:p.171

27 Banks, Journal, 10 October 1769, i:p.404
} 
assertions that their enemies were cannibals. Despite their initial dismissals of this claim, for the remainder of their circumnavigation of New Zealand the Endeavour crew were obsessed with Māori cannibalism.

Cook, like the rest of the Endeavour crew, enthusiastically sought evidence of Māori cannibalism. Furthermore, he, along with Banks in particular, sought to learn the peculiarities of the practice, such as whether it was only enemies whom Māori consumed. Moon asserts that Cook 'was hardly motivated by a specific search for cannibals, and never showed any great interest in their existence or the details of their practices'. ${ }^{28}$ 'Sinking their own personal feelings', Gary Hogg argues of Cook and Banks, 'they availed themselves of every opportunity for studying the natives and their customs' ${ }^{29}$ It was not, however, despite their feelings about Māori customs, particularly kaitangata, that Cook and Banks devoutly studied tikanga. Rather, it was because of their simultaneous fascination with and aversion to anthropophagy that they enthusiastically enquired about cannibalism.

Whilst preparing to depart New Zealand, Banks noted of Māori cannibalism: 'tho univarsaly acknowledg'd by them from our first landing at every place we came into, I confess I was very loth to give credit to' the claimed custom. He wrote that as evidence of the practice mounted, he 'proceeded to inquire as well as I could with the small knowledge of their language which I had and the Assistance of Tupia what were their customs upon this occasion'. ${ }^{30}$ Many of the Endeavour crew's enquiries were made through Tupaia - an arioi who had joined the voyage in Tahiti.

\footnotetext{
${ }^{28}$ Moon, p.66

${ }^{29}$ Hogg, p.174

30 Banks, 'Account of New Zealand', Journal, 30 March 1770, ii:p.30
} 
On first arriving in New Zealand, as Banks put it, Tupaia 'found that the language of the people was so like his own that he could tolerably well understand them and they him'. ${ }^{31}$ Tupaia, Cook added, 'always accompanies us in every excursion we make and proves of infinate service'.$^{32}$ When Tupaia informed Māori that he was from Havai'i, another name for the island of his birth, Ra'iatea (the place from where the other Society Islands were settled - the homeland), his audience would have immediately associated this with Hawaiki, the Māori ancestral homeland, thus greatly increasing his mana. $^{33}$

Although Tupaia is often mentioned in the Endeavour journals, his attendant Taiato rarely appears. Salmond notes of the two Tahitians who followed Tupaia in visiting New Zealand, '[n]either Hitihiti nor Mai shared Tupaia's linguistic abilities, which the high priest had developed during his arioi expeditions to various Pacific Islands.' They lacked, she adds, his 'charisma, his deep knowledge of traditional matters and his mana'. ${ }^{34}$ The importance of Tupaia's skill as a Polynesian linguist was as equally important as the similarities between te reo Māori (the Māori language) and Tahitian.

While he played a vital role in the British learning about Māori cannibalism, Tupaia was not vital to Europeans learning the simple fact that Māori were anthropophagi. The French crew of J.M.F. de Surville's voyage sailed around Cape Maria Van Diemen in stormy conditions at the same time the Endeavour was rounding the cape, but in the opposite direction, thus missing the British at the Bay of Islands by only a week. ${ }^{35}$ De Surville's crew had no Tupaia equivalent, yet the French, too, learned of Māori cannibalism. As

\footnotetext{
${ }^{31}$ Banks, Journal, 9 October 1769, i:p.401

32 Cook, Journal, 26 January 1770, i:p.240

33 Salmond, Trial, p.37

34 Ibid., p.220; Salmond, Aphrodite's Island, p.294

${ }^{35}$ Salmond, Two Worlds, p.317
} 
tokerau Māori had encountered the Endeavour crew only a week before meeting the French, the usual British enquiries of Māori cannibalism shaped what Māori expected of these French visitors. Thus on 23 December 1769 some of de Surville's crew reported to First Officer Guillaume Labé that a group of Māori had enquired of them, 'always by signs, to find out what we do with the prisoners we take and whether we eat them'. When the French replied that they bury their prisoners, the group 'told us that in their country, when they take prisoners they cut off their heads and show them to the people; next they open their stomachs and then they eat them'. 'From that', Labé wrote, 'I conclude that they are cannibals.' 36

Having quickly learned of Europeans' simultaneous fear of and fascination with cannibalism (and their desire to collect souvenirs of anthropophagy) from the British, Māori were quick to flaunt the custom to the French. On the second French visit to New Zealand, prior to expedition leader Marion du Fresne and twenty-four of his crew being killed by Māori at the Bay of Islands, Jean Roux reported that an unnamed rangatira 'gave me to understand that after killing them [enemies] they put them in the fire, and when they are cooked they eat them'. 'Seeing that that revolted and horrified me', Roux continued, 'he began to laugh and went on reaffirming what he had just said.'37 Māori were able to make European visitors aware of important information they wished to convey, with or without an interpreter; although

\footnotetext{
${ }^{36}$ Labé, journal, 23 December 1769, in Isabel Ollivier and Cheryl Hingley (transcription and translation), Early Eyewitness Accounts of Maori Life, 1: Extracts from Journals Relating to the Visit to New Zealand of the French Ship St Jean Baptiste in December 1769 under the Command of J.F.M. de Surville, Wellington:1987, pp.74-77

37 Roux, journal, June 1777, in Isabel Ollivier (transcription and translation), Early Eyewitness Accounts of Maori Life, 2: Extracts from Journals Relating to the Visit to New Zealand in May-July 1772 of the French Ships Mascarin and Marquis de Castries under the Command of M.-J. Marion du Fresne, Wellington:1985, pp.168-169; Augustus Earle, A Narrative of Nine Months' Residence in New Zealand, in 1827, London:1832, pp.148-150
} 
it is important to note that the information they wished to convey was influenced by preceding interpreter-influenced contact.

On 15 November 1769 Cook reported: [t]hey confirm the custom of eating their enimies so that this is a thing no longer to be doubted' ${ }^{38}$ Earlier, at Uawa (Tolaga Bay), Tupaia had asked a tohunga and other Māori 'whether or no they realy eat men which he was loth to beleive'. '[T]hey answerd in the affirmative', Banks reported, 'saying that they eat the bodys only of those of their enemies who were killd in war' ${ }^{39}$ Later recalling the aforementioned three kidnapped Māori youths' indications of cannibalism, Banks noted '[s]ince that [day] we have never faild wherever we went ashore and often when we convers'd with canoes to ask the question'. Of these conversations, the botanist reported 'we have without one exception been answerd in the affirmative, and several times as at Tolaga and today [at the Bay of Islands] the people have put themselves into a heat defending the Custom'. ${ }^{40}$ These persistent Tahitian and European enquiries about cannibalism quickly made clear to Māori the visitors' simultaneous doubts about, horror at, obsession with, and extreme fear of their practice of kaitangata.

Underlying the European obsession with internecine Māori cannibalism was the fear that it would be extended to eating Europeans. In December 1769, while departing the Bay of Islands, the Endeavour struck a submerged rock. Banks, who was undressing for bed at the time, ran quickly up on deck. '[T]he almost certainty of being eat as soon as you come ashore', he observed, 'adds not a little to the terrors of shipwreck'. ${ }^{41}$

\footnotetext{
38 Cook, Journal, 15 November 1769, i:p.203

39 Banks, Journal, 25 October 1769, i:p.420

40 ibid., 1 December 1769, i:p.443

41 ibid., 5 December 1769, i:p.446; Hawkesworth, ii:p.363
} 
The following month, in Queen Charlotte Sound, some of the Endeavour crew went ashore, where they encountered a group of Māori. From this group Cook obtained the bone of the fore arm of a Man or a Woman which was quite fresh and the flesh had been but lately pick'd off which they told us they had eat'. These people then told the visitors that 'but a few days ago they had taken Kill'd and eat a Boats crew of their enemies' ${ }^{42}$

By this time, as Cook noted, '[t]here was not one of us that had the least doubt but that this people were Canabals'. Yet the Europeans' morbid fascination with the custom drove them to seek yet stronger proof. '[I]n order to be fully satisfied of the truth of what they had told us', the Europeans declared that the forearm given to them 'was not the bone of a man but that of a Dog'. By way of reply, one of the group 'with great fervency took hold of his fore-arm and told us again that it was that bone and to convence us that they had eat the flesh he took hold of the flesh of his own arm with his teeth and made shew of eating'.

Later that day another group of Māori came alongside the Endeavour. Cook reported that from these people Banks obtained 'a bone of the fore arm in much the same state as the one before mention'd and to shew us that they had eat the flesh they bit a[nd] naw'd the bone and draw'd it thro' their mouth and this in such a manner as plainly shew'd that the flesh to them was a dainty bit' ${ }^{43}$

The following day another small waka (canoe) came out to the Endeavour. Tupaia, ever the sceptic of what Māori told him, ${ }^{44}$ enquired of its crew

\footnotetext{
${ }^{42}$ Cook, Journal, 17 January 1770, i:pp.235-236

43 ibid., i:pp.236-237

44 For example when, off the Cavalli Islands, Māori informed Tupaia that their ancestors had voyaged to an island to the far northwest where the people ate pigs, he called them a 'parcel of Liars',
} 
whether what they had been told the previous day was true 'and was told over again the same story'. 'But where are the sculls ... do you eat them?', Tupaia asked, stating that they would not be convinced until they saw these. Topaa, an 'old man who had first come on board the ship', answered that they did not eat the heads but did eat the brains, declaring 'tomorrow I will bring one and shew you' ${ }^{45}$

Topaa did not return the following day, likely because, as he had indicated to the visitors, his people were expecting a tauā to soon arrive seeking utu for the killing and eating which had so fascinated the Endeavour crew. He did return, however, on 20 January, as Banks noted, 'according to his promise, with the heads of 4 people which were preservd with the flesh and hair on ... the brains were however taken out as we had been told'. Banks concluded this day's journal entry by noting a lack of cultivated ground in the area, musing 'I suppose they live intirely upon fish dogs and Enemies' ${ }^{46}$

Though the Endeavour crew were, by this time, convinced Māori were anthropophagi, the Enlightenment-influenced officers and gentlemen of the ship sought irrefutable eyewitness proof of the practice. The Europeans' (and Tupaia's) obsession with the reported Māori custom led to persistent enquiries about and requests for demonstrations of kaitangata. Furthermore, while waxing lyrical about how horrific cannibalism was, Banks also begged Māori to trade the remains of victims of the practice with him. In addition to the aforementioned forearm, Banks bullied Topaa into trading one of his

declaring their 'story a great lye for your ancestors would never have been such fools as to come back without' pigs. Tupaia also directly accused Topaa of being 'given too much to Lying'; Banks, Journal, 9 December 1769 \& 29 January 1770, i:pp.446-447 \& 460; see also: 5 \& 19 February 1770, i:pp.462-464 \& 468-469

45 Banks, Journal, 17 January 1770, i:p.455-456

46 ibid., 20 January 1770, i:p.457 
preserved heads for 'a pair of old Drawers of very white linnen'. ${ }^{47}$ And Banks was not the only one; many of the Endeavour sailors became obsessed with collecting Māori bones as souvenirs. Like explorers before them, sealers and whalers also traded for mokomōkai, tattooed, preserved Māori heads; as did later visitors and settlers. ${ }^{48}$ The unrelenting discourse on cannibalism led to Māori affirming and demonstrating the custom in an increasingly exaggerated manner.

Provisions, including meat, were often on the minds of the Endeavour crew whilst they were encountering Māori. As Salmond observes, for the Endeavour's officers and gentlemen - including principal commentators Cook and Banks - the shipboard meals were not as good as those which they were used to at home in Britain. Most of the crew, however, came from poor English families, who 'would have considered a hot meal every day and meat four days a week good eating, even though the meat was rarely fresh'. ${ }^{49}$ On New Year's Day 1770, off Cape Reinga, Banks noted: 'our Surveyors suppose the Cape shapd like a shoulder of mutton with the Knuckle placd inwards' ${ }^{50}$ Later, off the east coast of Te Wai Pounamu, the crew resumed their debate as to whether the land which lay to the west was part of the Great Southern Continent. They were divided into two parties: some believed New Zealand to be part of the continent they were seeking, others thought not. Banks reported that he believed it was, 'tho sorry I am to say', he added, 'that in the ship my party is so small that I firmly beleive that there are no more heartily of it than myself and one poor midshipman, the rest begin to sigh for roast

47 Banks, 'Account of New Zealand', Journal, 30 March 1770,ii:p.31; Salmond, Trial, pp.144-145

48 Sydney Gazette and New South Wales Advertiser, 8 January 1820, p.3; Harry Morton, The Whale's Wake, Dunedin:1982, p.135; June Starke, 'Introduction', in John Boultbee, Journal of a Rambler: the Journal of John Boultbee, June Starke (ed.), Auckland:1986, p.xlii; Wilson, From Hongi, pp.161-162

49 Salmond, Two Worlds, p.110

50 Banks, Journal, 1 January 1770, i:p.449 
beef $^{\prime}{ }^{51}$ It is not suggested here that incessant talk of cannibalism was making the Europeans hungry for fresh meat; but perhaps all that talk of fresh meat affected the Europeans' simultaneous fascination with and aversion to the consumption of human flesh.

European attempts to understand cannibalism were made within the wider context of both Māori and Pākehā (European) attempts to understand the other's eating habits, particularly with regard to meat. In an interesting turn of phrase Sub-Protector George Clarke (junior) recalled that while travelling around Otago in the snow in 1844: '[w]e had a strange craving for meat in the intense cold, and the want of it made everybody savage. ${ }^{52}$ In 1820, while visiting New Zealand for the third time, Marsden was presented with 'a cat suspended by a cord at the end of a long spear, not quite dead' to be prepared for dinner. He told the rangatira who had offered the cat that "white people never eat cats nor dogs - that they are tabooed animals and never used as an article of food'. Marsden noted that Māori 'all seemed to think it strange that we did not eat these animals which they considered such choice food'. '[W]e eat other animals which they had not seen, and also hogs' the evangelical informed his host, after which he was presented with 'a very large fat hog' for his meal. ${ }^{53}$

By the time of Cook's second Pacific voyage, European sailors aboard the Resolution and Adventure were happily eating dog meat. Johann Forster mused: '[i]t is really a pity, that in Europe there are such terrible prejudices among mankind, as to think cats, dogs, horse \& other Animals (we are not used to eat by custom) to be unclean \& an Object of Abomination'. '[T]rue Philosophy \& common sense', he concluded, 'seems to be on my Side \& self

\footnotetext{
${ }^{51}$ ibid., 24 February 1770, i:p.470

52 Clarke (junior), Notes, p.65

${ }^{53}$ Marsden, 'Third New Zealand Journal', Letters and Journals, p.284
} 
interest \& prejudice on theirs' ${ }^{54}$ Yet some of the Endeavour crew had earlier expressed reservations about eating a shark caught in the Atlantic Ocean. While Banks himself enjoyed the shark, which was 'stewd for dinner', he noted 'some of the Seamen did not seem to be fond of him, probably from some prejudice founded on the species sometimes feeding on human flesh'.$^{55}$

As noted above, the three Māori kidnapped at Tūranga-nui were bemused by the meat offered to them aboard the Endeavour. Later describing his father's meeting with Cook at the Bay of Islands in 1769, Patuone recalled:

Tapua went on board the ship, and the leader of the goblins presented him with a red garment and with the salt flesh of an animal. It was cooked flesh, with both fat and lean meat on the one piece ... Food of this kind had not been known to the Maori; they found it to be sweet, and very good. ${ }^{56}$

This is one of a number of reported instances in which Māori were often simultaneously fascinated with and confused by European diet, just as Europeans were of Māori eating habits.

$\not$

Within the Endeavour journals Tupaia is often referred to as even more horrified at Māori cannibalism than the European crew of the ship. Cook reported that Tupaia, 'who holds this custom in great aversion hath very often argued with them against it'. ${ }^{57}$ Banks went further, suggesting Tupaia, 'who had never before heard of such a thing takes every Occasion to speak ill of'

\footnotetext{
54 J.R. Forster, 10 June 1773, The Resolution Journal of Johann Reinhold Forster, 1772-1775, Michael E. Hoare (ed.), 4 vols., London:1982, ii:pp.303-304; see also: George Home, Memoirs of an Aristocrat, and Reminiscences of the Emperor Napoleon, London:1838, pp.271-272; Salmond, Trial, pp.1-9

55 Banks, Journal, 29 September 1768, i:p.168; Thomas, Discoveries, p.41

56 quoted in Salmond, Trial, p.135 \& Salmond, Two Worlds, p.221

57 Cook, 'General Discription of [New Zealand]', Journal, c.31 March 1770, i:p.282
} 
cannibalism..$^{58}$ Tupaia would have had knowledge of cannibalism - Tahitian myths told of cannibal women. ${ }^{59}$ Indeed, when Hitihiti returned to Tahiti and gave accounts of Māori cannibalism, some Tahitians studied the preserved head of a young Māori obtained by Richard Pickersgill and told of a period in history when cannibals had inhabited Tahiti. ${ }^{60}$ As Belich notes in relation to Tupaia's aversion: 'Tahitians had abandoned cannibalism centuries before, and converts are often the worst fanatics. ${ }^{61}$ Salmond suggests it likely that Tupaia considered cannibalism blasphemous, as in Tahiti it was gods who consumed enemies' spirits. ${ }^{62}$ As conversations were often interpreted through him, Tupaia's horror influenced the discourse on cannibalism on both the Māori and the European sides of the rhetoric.

The European portrayal of Tupaia as more outraged at Māori cannibalism than themselves indicates that it was not only Europeans to whom the image of Māori was dominated by cannibalism. As Salmond has shown, the geographic list of Pacific Islands related to Spaniard Andia y Varela by the Tahitian Puhoro in 1775 differed from those islands Tupaia had told Cook of. Puhoro's list included several new islands, including "“[Te Wai] Pounamu", which was said to have very high mountains and a barren landscape, with plenty of fish, inhabited by cannibals'. Unlike Tupaia, who had died in Batavia, Hitihiti, who had travelled with Cook on his second Pacific voyage, returned to Tahiti to share his newly acquired knowledge, including that of anthropophagi. When Ma'i, who had both visited New Zealand and spent two years in England, first encountered Cook Island Maori on 29 March 1777, he asked them whether they were cannibals. When the Tahitian later saw

\footnotetext{
58 Banks, Journal, 1 December 1769, i:p.443

59 Douglas L. Oliver, Ancient Tahitian Society, 3 vols., Honolulu:1974, ii:p.714; Salmond, Two Worlds, p.176

60 Salmond, Trial, pp.248-249

61 Belich, Making Peoples, p.20

62 Salmond, Aphrodite's Island, p.230
} 
these same people preparing an earth oven, he asked if he and his European companions were about to be cooked and consumed. ${ }^{63}$ Influenced by his encounters with Māori, Ma'i developed an intense fear of being eaten.

Artist Augustus Earle later related an account of two men of the island of Tikopia, in the Solomon Islands, meeting Māori in New Zealand in 1827. 'These poor creatures', Earle detailed, 'upon landing, shook with fear, and trembled greatly when they beheld the New Zealanders, whose character for cannibalism had reached even their remote island'. The Māori present, 'with characteristic cunning', he noted, 'perceiving the horror they had created, tormented them still more cruelly, by making grotesque signs, as if they were about to commence devouring them'. ${ }^{64}$ Cannibalism was ingrained in images of Māori held by other Pacific Islanders a mere five years after what was probably the first contact between Māori and other Polynesian peoples in over 600 years, just as it was embedded in European images of Māori within a few years of Europeans having set foot on the New Zealand shore.

Upon departing Queen Charlotte Sound in June 1773, William Wales, astronomer on Cook's third Pacific voyage, wrote of Māori cannibalism in his journal. 'Before going to leave this land of Canibals, as it is now generally thought to be', he observed, 'it may be expected that I should record what bloody Massacres I have been a witness of; how many human Carcases I have seen roasted and eaten'. At the very least, Wales believed, he should relate facts which 'confirm the Opinion, now almost universally believed, that the New Zealanders are guilty of this most detestable Practice'. He went on to note, however, that he had 'not seen the least signs of any such custom being amongst' Māori. Wales' journal entry highlights that violent cannibals

\footnotetext{
63 ibid., pp.356 \& 406-407, italics in Salmond

${ }^{64}$ Earle, p.205
} 
is what he expected to encounter upon visiting New Zealand, and, as Salmond suggests, that sailors wanted good tales to tell when they returned to Europe. ${ }^{65}$

Prior to sailing from Ship Cove in Queen Charlotte Sound in 1770, Banks cited an incident which outlines both the degree to which cannibalism was dominating thoughts and discussions among the Endeavour crew and the difficulty experienced by Europeans in communicating with Māori about the practice. He wrote:

[t]wo of our boats went out different ways and returned at different times; the people of one said that they had met with a double canoe who told them that they had a few days ago lost a female child who they suspected had been stole and eat by some of their neighbours; the other said that they had also met a double canoe whose people told them that they had yesterday eat a child, some of whose bones they sold them. From hence many of our gentlemen were led to conclude that thefts of this kind are frequent among these Indians.

Banks reasoned that the two European expeditions 'saw one and the same canoe and only differently interpreted the conversation of the people, as they know only a few words of the language, and eating people is now always the uppermost Idea in their heads' ${ }^{66}$

Moon sees this journal entry of Banks' as evidence that the gentlemanbotanist was becoming aware of Māori agency in cannibalism discourse. Banks' 'well-developed intuition told him that this particular claim of cannibalism - with the added shock value of a child as the victim - ought to be treated with a pinch of salt'. ${ }^{67}$ Moon, however, overlooks the two contrary tales told to Banks, the confusion this caused, and Banks' claim that said con-

\footnotetext{
${ }^{65}$ quoted in Salmond, Trial, p.190

66 Banks, Journal, 4 February 1770, i:p.462

67 Moon, p.72
} 
fusion derived from communication difficulties and the pervasive fear of and fascination with cannibalism aboard the Endeavour.

Both the European visitors' coexisting obsession with and horror at Māori cannibalism, and the confusion caused by the problems in Māori-European communication (particularly pronounced when Tupaia was not present), greatly influenced the European conceptualisation of Māori violence, particularly cannibalism. Later, in noting examples of the difficulty experienced by Europeans in learning the subtleties of te reo Māori, the Reverend William Yate wrote of 'one [phrase] which had often made a native angry, as it refers to one of the gravest curses you can express: and if one native were to make use of it to another, a satisfaction would be sought, and the individual who spoke the sentence would be severely punished': “'Will you eat me," instead of "Will you eat with me?"'68

From the Endeavour crew's very first contact Europeans began to learn of Māori cannibalism. Fuelled by a simultaneous horror at and yet fascination with cannibalism, Europeans persistently engaged in discourse with Māori regarding the practice. Māori were quick to perceive the intense European fear of cannibalism, and utilised this to actively portray themselves as a people to be frightened of. Drawing on this Māori agency, Europeans incorporated their knowledge of Māori cannibalism into their conceptualisation of Māori as 'a most warlike people'.

\footnotetext{
68 William Yate, An Account of New Zealand and of the Church Missionary Society's Mission in the Northern Island [1835], Wellington:1970, p.230n
} 
Angela Ballara argues that during the early-contact period warfare was endemic in Māori society, as it had been prior to contact with Europeans. ${ }^{69}$ In discussing $\operatorname{take}^{70}$ and utu, she further suggests that '[w]arfare in Māori society at about 1769 , and onwards through to 1840 or a little later, was not about "avenging insults"; it was about the resolution of conflict.' 'Conflict could be resolved without resorting to actual war', she writes, 'but ... the mechanisms of peaceful dispute resolution often failed and war resulted'. 'Wars and migrations', Ballara concludes, 'were endemic to Māori society because they were mechanisms for resolving disputes and clashes between descent groups. ${ }^{\prime 71}$

Converse to Ballara, Belich argues that pre-contact Māori warfare was not endemic, and that the belief that it was arose from Māori who had been educated during a time of unprecedented Māori warfare, the 1820s. At that time traditions which told of warfare were naturally emphasised in their education at the expense of less-useful historical accounts. 'Conflicts with particular enemies, which might actually have occurred sporadically over centuries', he argues, 'were telescoped into cohesive wars. The peaceful times between were squeezed out'.

The strain war had on resources compounded the problem of seeing Māori warfare as endemic. 'Sustained and intensive conflict, however desirable', Belich concludes, 'was a luxury [Māori] could rarely afford'. Like Ballara, Belich also notes the role played by take and utu. He sees these, however, as converging with other economic factors, and further suggests that well-

\footnotetext{
69 Angela Ballara, 'The Role of Warfare in Maori Society in the Early Contact Period', JPS, 85:4, 1976, pp.487-506; Angela Ballara, 'Warfare and Government in Ngapuhi Tribal Society, 1814-1833: Institutions of Authority and the Function of Warfare in the Period of Early Settlement 1814-1833, in the Bay of Islands and Related Territories', MA thesis, University of Auckland:1973, passim

70 The te reo Māori word take (reason/purpose/cause) is italicised to avoid confusion with the English verb 'take'.

71 Ballara, Taua, pp.83 \& 444
} 
established peacemaking procedures resulted in violence occurring less often than the frequency proposed by Ballara. ${ }^{72}$

Contrary to most late-eighteenth- and early-nineteenth-century commentators, J.L. Nicholas concluded of Māori: 'their wars are not at all so destructive as might be imagined'. Nicholas, who visited New Zealand with Marsden in 1814-1815, further noted that he was 'rather inclined to believe, that however great is their impatience for war, they are still not insensible to the dictates of peace, but are often ready ... to compromise their feuds with a mutual spirit of forbearance'. ${ }^{73}$ That Nicholas noted his comments on the frequency of Māori warfare were contrary to popular belief indicates the degree to which Māori were envisaged as warlike by Europeans during this period.

Earle, who resided in New Zealand for nine months in 1827-1828, wrote of Māori 'peace-makers'. 'Although the New Zealander is so fond of war, and possesses such warlike manners', he observed, 'peace-makers' were 'held in the highest respect'.$^{74}$ Māori violence was strictly governed by tikanga such as muru (ritual confiscation/plunder), take, and utu. Cook and Banks encountered evidence of muru in their observations of pā (fortified villages) at numerous locations on the New Zealand coast. At Mercury Bay they perceived a lack of ornamentation of Māori possessions, likely the result of muru. Best, who, as Belich notes, 'pretended respect for tradition to the elders he interviewed, and disrespect for it to his European readers' ${ }^{\prime}{ }^{75}$ wrote of muru: ' $\mathrm{i}$ ]f a man had the misfortune to break a leg, or to get married, or to possess a gay wife, he was liable to be plundered of all his portable property'. 'There was', the ethnographer wryly concluded, 'a charming element of un-

\footnotetext{
72 Belich, Making Peoples, pp.75-78; Belich, 'Race and New Zealand', pp.15-16

73 Nicholas, ii:pp.38 \& 112

${ }^{74}$ Earle, p.141

75 'He outsmarted himself on both counts', Belich concludes, 'and his work is both suspect and vital'; Belich, Making Peoples, p.24
} 
certainty in Maori life. ${ }^{\prime 76}$ Tikanga such as muru ensured pre-contact Māori violence was not as extensive as Ballara suggests, although perceptions of widespread violence remained. Māori violence did, however, drastically increase as a result of European contact, as is examined in chapter four.

Having become obsessed with Māori cannibalism - actively seeking illustrations of the practice throughout their visit - the Endeavour crew incorporated anthropophagy into the developing image of Māori as warlike. Upon departing New Zealand Cook concluded of Māori cannibalism: '[i]t is reasonable to suppose that men with whome this Custom is found seldom or never give quarter to those they overcome in battle'. ${ }^{77}$ Cook saw the muchdiscussed Māori custom of consuming part of one's enemies killed or captured in warfare as further evidence that Māori were a warlike people.

Prior even to their first encounter with Māori, Europeans assumed that the inhabitants of the then unknown lands of New Zealand would be warlike. Tasman was warned that 'extreme caution will everywhere have to be used, seeing that it is well known that the southern regions are peopled by fierce savages'. He was instructed - evidently without intended irony - to be 'well armed ... since experience has taught in all parts of the world that barbarian men are nowise to be trusted, because they commonly think that the foreigners who so unexpectedly appear before them have come only to seize their

\footnotetext{
76 Elsdon Best, 'Maori Agriculture: Cultivated Food-Plants of the Maori and Native Methods of Agriculture', JPS, 39:4, 1930, p.364; see also: Elsdon Best, 'Omens and Superstitious Beliefs of the Maori, Part I', JPS, 7:3, 1898, pp.119-136

77 Cook, 'General Discription of [New Zealand]', Journal, c.31 March 1770, i:p.282
} 
land' ${ }^{78}$ The Dutch encounter with Māori was to further evince this assumption. Upon Tasman's return to Batavia and subsequent reporting on his adventures, Antonio van Diemen, governor-general of the Dutch colony, declared Māori to be 'of a malignant and murderous nature' ${ }^{79}$

Having read Tasman's account of his encounter, Cook and Banks arrived in New Zealand with expectations of Māori as warlike. In 1642 Tasman had concluded 'the detestable deeds of these Natives ... must teach us to consider the inhabitants of this country as enemies': four of his crew having been killed by Māori. This violent encounter led Tasman to name the bay in which he had anchored 'Moordenaers Baij', which led to Raukawa-moana (Cook Strait) appearing on numerous seventeenth- and eighteenth-century maps as the 'Baye des Assasins' or 'Murderers' Bay' ${ }^{80}$

During the first month of his visit to New Zealand, spent sailing down and back up the east coast of Te Ika-a-Māui (the North Island), Cook noted that he had observed numerous Māori pā. 'From this', he mused, 'it should seem that this people must have long and frequent wars, and must have been long accustom'd to it otherwise they never would have invented such strong holds as these'.$^{81}$ Having circumnavigated New Zealand, Banks observed: '[t]he state of war in which they live, constantly in danger of being surprizd when least upon their guard, has taught them not only to live together in

\footnotetext{
78 Justus Schouten, 'Instructions for Skipper Commander Abel Jansz. Tasman', 13 August 1642, Robert McNab (ed.), Historical Records of New Zealand (HRNZ), 2 vols., Wellington:1908 \& 1914, ii:p.10

79 Antonio van Diemen, 'Resolution of the Governor-General and Councillors on Tasman's Return to Batavia', 19 June 1643, HRNZ, ii:p.35

80 'Moordenaers Baij' was Te Tai Tapu, now known as Golden Bay, at the northern tip of the South Island. Although Tasman indicated he believed the South and North Islands to be separated by a body of water, his depiction of the west coast of New Zealand showed Raukawa-moana as a large bay or harbour on many subsequent world maps (often optimistically attached to Terra Australia Incognita), which, because of the small size of the outline relative to the world, depicted Raukawa-moana as the 'Baye des Assasins'; Tasman, journal, 19 \& 24 December 1642, HRNZ, ii:pp.23-26

${ }^{81}$ Cook, Journal, 12 November 1769, i:pp.198-201
} 
towns, but to fortify those towns' ${ }^{82}$ From observing pā the Endeavour crew concluded Māori were a warlike people.

While at Mercury Bay Cook noted that local waka were 'mean and without ornament', as were their 'houses or hutts and in general every thing they have about them'. Inadvertently commenting on muru, though not allowing for the custom to be an alternative to war, Cook was quick to point to Māori being warlike as an explanation for this lack of decoration. 'This may be owing to the frequent wars in which they are certainly ingaged', he concluded, 'strong proofs of this we have seen, for the people ... place' $\mathrm{d}$ themselves in such a manner when they laid down to sleep as plainly shewed that it was necessary for them to be always upon their guard' ${ }^{83}$ Furthering conclusions made from visiting pā, from observations of Māori whare (houses), waka, and whānau the Endeavour crew avowed that Māori were a warlike people.

It was not, however, solely through European agency that Māori were perceived as warlike. Māori overtly displayed their martial qualities to visiting Europeans. Upon departing New Zealand Banks observed '[t]heir words were almost universaly the same, "haromai haromai hare uta a patoo patoo 'oge", which he translated as 'come to us, come to us, come but ashore with us and we will kill you with our Patoo patoos'. '[I]n this manner', Banks declared, 'they continue to threaten us, venturing by degrees nearer and nearer till they were close alongside, at intervals talking very civily and answering any questions we askd them but quickly renewing their threats' ${ }^{84}$ Banks' claim

82 Banks, 'Account of New Zealand', Journal, 30 March 1770, ii:p.31

83 Cook, Journal, 15 November 1769, i:p.203

${ }^{84}$ Cook wrote: '[a]s soon as they came within about a stones throw of the Ship they would there lay and call out Haromai hareuta a patoo age, that is come here, come a shore with us and we will kill you with our patoo patoo's'. Hawkesworth repeated Banks' claim almost word for word; Cook, 'General Discription of [New Zealand]', Journal, c.31 March 1770, i:p.281, italics in original; Banks, 'Account of New Zealand', Journal, 30 March 1770, ii:p.29, italics in original; Hawkesworth, iii:p.467; see also: Banks, Journal, 24 October 1769, i:p.419 
suggests that much of the Europeans' questioning of Māori (often through Tupaia) occurred in the context of Māori threatening the visitors - a context which shaped both European enquiries and Māori responses. Enquiries about cannibalism and other forms of violence made in this context were thus likely to be answered in the manner of exaggerated threats: yes, we are warlike and we do eat our enemies, so beware.

Hawkesworth, that meddling editor of the Endeavour journals, ${ }^{85}$ built upon Cook's and Banks' connection between Māori cannibalism and Māori as warlike. ${ }^{86}$ Concluding his retelling of the Endeavour's circumnavigation of New Zealand, Hawkesworth drew on Banks' observations with which this chapter opened. The editor noted that although both Māori men and women had 'mild and gentle' 'dispositions' and treated one another 'with the tenderest affection', they were also 'implacable towards their enemies, to whom ... they never give quarter' ${ }^{87}$ Hawkesworth mused that '[i]t may perhaps, at first, seem strange, that where there is so little to be got by victory, there should so often be war; and that every little district of a country inhabited by a people so mild and placid, should be at enmity with all the rest.' He believed, however, that Māori warfare was due to the fact that 'their principal food is fish'. Because of this, both inland and coastal Māori 'must be frequently in danger of perishing by famine'. This accounted, Hawkesworth believed, for both heavily fortified pā and Māori cannibalism. He concluded that if hunger did account for the origin of Māori cannibalism 'the mischief does by no means end with the necessity that produced it', for 'it will naturally be adopted on the other by revenge'.

\footnotetext{
85 Pearson, 'Hawkesworth's Alterations', pp.45-72; Thomas, Discoveries, pp.151-157 \& 256; Standfield, 'Warriors and Wanderers', pp.28-85

${ }^{86}$ Standfield, 'Warriors and Wanderers', pp.49-51

87 French explorers also contrasted Māori 'savage' behaviour towards enemies with tender affection for whānau; Andrew Sharp (ed.), Duperrey's Visit to New Zealand in 1824, Wellington:1971, pp.34, $44 \& 85$
} 
Hawkesworth further asserted that '[a]mong those who are accustomed to eat the dead, death must have lost much of its horror; and where there is little horror at the sight of death, there will not be much repugnance to kill.' For any who doubted his convoluted argument which followed, Hawkesworth suggested: 'let him ask himself, whether in his own opinion he should not be safer with a man in whom the horror of destroying life is strong ... than in the power of a man who under any temptation to murder him would be restrained only by considerations of interest ' 88 The representation of Māori as cannibals thus became an image of Māori as warlike cannibals. 'If the head of a tribe is killed and eaten', Marsden later wrote, 'the survivors consider it the greatest disgrace that can befall them, and, in their turn, they seize the first opportunity to retaliate in the same way. By this means their mutual contests are continually kept alive and war becomes their study and their trade. ${ }^{\prime 89}$

Cook's and Banks' observations of Māori were widely circulated in Britain and continental Europe - particularly through Hawkesworth's edited collection. ${ }^{90}$ The image of Māori as warlike cannibals painted by the Endeavour explorers was to have an immense influence on European perceptions of Māori throughout the nineteenth century and beyond. When visiting the Bay of Islands aboard the Beagle in December 1835, Charles Darwin noted of Māori that 'a more warlike race of inhabitants could not be found in any part of the world'. Darwin's evidence for such a claim: 'as described by Captain Cook ... their defiance, of "Come on shore and we will kill and eat you

\footnotetext{
88 Hawkesworth, iii:pp.445-446

89 Marsden, 'Third New Zealand Journal', Letters and Journals, p.285

90 B. Smith, European Vision, p.112
} 
all"'. ${ }^{91}$ Significantly, Darwin misquoted the phrase. As Thompson points out, this 'is not what Hawkesworth said that Cook [nor Banks] said that Tupaia ... said that the Maori said'. ${ }^{92}$ In Darwin's mind, as in the minds of many Europeans, Māori as cannibals and Māori as warlike were inseparable notions. Prior to Darwin's visit, numerous missionary-settlers had set sail for New Zealand expecting to encounter Cook's 'brave open warlike people'; Hawkesworth's people 'inured to war' ${ }^{93}$

The Endeavour crew ensured that the image of Māori circulating in Europe at the beginning of the nineteenth century was one of warlike, cannibal 'savages'. John Savage, a ship's surgeon who visited the Bay of Islands in spring 1805, expressed great surprise that the Māori whom he encountered did not conform to what he had been led to expect. Upon first encountering Māori, who flocked to the ship as soon as it came to anchor, Savage noted that '[i]n a country that has been described as being peopled by a race of cannibals, you are agreeably surprised by the appearance of the natives, who betray no symptom of their savage ferocity'. Savage went on to note that seeing Māori cultivations, whare, and the abundance of fish and potatoes offered for trade 'tend forcibly to remove the prejudices you have imbibed from former accounts of this country and its inhabitants'. ${ }^{94}$

${ }^{91}$ Charles Darwin, Journal of Researches into the Geology and Natural History of the Various Countries Visited by H.M.S. Beagle, London:1839, p.499; cf. Cook 'General Discription of [New Zealand]', Journal, c.31 March 1770, i:p.281; Hawkesworth, iii:p.467; Banks, 'Account of New Zealand', Journal, 30 March 1770, ii:p.29

92 Thompson, p.111, emphasis in original

93 Cook, 'General Discription of [New Zealand]', Journal, c.31 March 1770, i:p.281; Hawkesworth, iii:p.447; Hawkesworth is here drawing upon Banks, 'Account of New Zealand', Journal, 30 March 1770, ii:p.12

94 John Savage, Some Account of New Zealand; Particularly the Bay of Islands, and Surrounding Country [1807], Dunedin:1966, pp.3-4 
By the time the first missionaries set out for New Zealand the image of Māori as warlike cannibals was well-established in Britain and continental Europe. With this image in mind, the first European settlers arrived in New Zealand seeking substantiation of the reputation of Māori as warlike cannibals. Upon first coming across 'the remains of a human body which had been roasted', Earle was 'more shocked than surprised, for I had been informed of the character of the New Zealanders long before my arrival amongst them'.$^{95}$ F.E. Maning, who settled at Hokianga in 1833, recalled that as he approached the New Zealand shore for the first time he 'began in a most uncomfortable manner to remember all the tales I had ever heard of people being baked in ovens'. 'I felt, to say the least, rather curious', he added, 'as to the then existing demand on shore for butchers' meat'. Maning further wondered 'whether possibly this same "haere mai" might not be the Maori for "dilly, dilly, come and be killed"' ${ }^{96}$ Writing 'raw-head-and-bloody-bones stories ... has', the Pākehā-Māori complained, 'been too much the fashion with folks who write of matters Māori' ${ }^{97}$

Māori, however, were often keen to reify their reputation. Belich argues that once it was apparent 'that cannibalism horrified genteel Europeans, Maori tended to allege that it was something that happened down the road' ${ }^{98}$ Indeed, in 1821 WMS missionary Samuel Leigh reported that Māori were lately reluctant to have the missionaries witness kaitangata. ${ }^{99}$ On his 1805-1806

\footnotetext{
95 Earle, p.13

96 As Belich notes, although Maning wrote of beating Māori in wrestling matches, Markham wrote of him losing said contests, 'and an underlying resentment of Maori dominance pervades' the Pākehā-Māori's observations of Māori. Markham further described Maning as 'a double faced sneaking Thief', who 'would have done Honor to the back Woods in America'; Edward Markham, New Zealand or Recollections of It, E.H. McCormick (ed.), Wellington:1963, pp.32 \& 32n; Belich, Making Peoples, pp.185-186

97 Maning, Old New Zealand, pp.4, 16 \& 163-164

98 Belich, Making Peoples, p.147; Evidence of Ensign McCrae given before Commissioner Bigge, May 1821, HRNZ, i:p.540

99 Samuel Leigh, 'New Zealanders Cannibals, as related by Mr. Samuel Leigh, Wesleyan Missionary, lately come from New Zealand', Evangelical Magazine, London:1821, HRNZ, i:pp.573-575
} 
visit to New South Wales Te Pahi denied the existence of cannibalism in his dominions and asserted to Governor Philip Gidley King that it was other Māori who engaged in the practice. During the early years of Māorimissionary contact in the Bay of Islands Māori often flaunted their cannibalism and their warlike qualities, however, as they had done to previous European visitors. ${ }^{100}$

Missionary writings must be viewed in the context in which they were written. Missionaries were well aware that they needed to portray Māori as 'savage' enough to be deserving of funds - which supported the missionaries' livelihood - yet not too 'savage' as to be beyond 'saving', or, later, that the mission was not succeeding in its task, the punishment for which was the withdrawal of funds. It is important too, however, not to overemphasise this missionary lens, which can largely be overcome by acknowledging and deconstructing the differing portrayals of Māori offered in the different mediums in which missionaries wrote.

While both letters to missionary society secretaries and missionary journals were read by the societies' committees, the latter were sent (and read) on a more delayed and intermediary basis, and tended to reflect a less formal and more personal medium for missionary writing. Personal letters to family and friends offer yet another multifarious context. Clarke, for example, wrote to his father in the frame of attempting to convince him that giving his life to the task of 'civilising' and Christianising Māori had been a worthy enterprise, both spiritually and financially. Yate's published Account of New

\footnotetext{
100 Tuki, too, had 'obstinately denied that the whole of the New Zealanders were cannibals' to Governor King. In 1820 Captain Skinner noted that Bay of Islands Māori, while admitting other iwi were cannibals, denied that they themselves partook in the custom, 'as they know it is not approved of by Europeans'; Philip Gidley King, 'New Zealand Natives', 2 January 1806, HRNZ, i:pp.266-267; David Collins, An Account of the English Colony in New South Wales, from its First Settlement in January 1788, to August 1801 [1802], second edition London:1804, pp.344; Captain Skinner to Commissioner Bigge, 12 September 1820, HRNZ, i:p.496
} 
Zealand was closely entwined with, though not financed by, the CMS, and was initially supported by the missionary society committee, though it was later scorned by Yate's fellow missionaries. The missionary conceptualisation of Māori violence was shaped by for whom the evangelicals were writing. ${ }^{101}$

Frustrated in his attempts to reform convicts and redeem Aboriginal peoples of New South Wales, Marsden turned his attention to Māori, a number of whom were visiting Port Jackson at the beginning of the nineteenth century. In February 1807 Marsden sailed aboard the Buffalo for England, where he hoped to convince the CMS to finance a mission to Māori. He arrived in November and remained fourteen months, visiting the CMS on numerous occasions. His persistence paid off, and the committee agreed to send three missionaries to New Zealand. 'No clergymen, however', as Marsden noted, 'offered their services on this occasion.' 'The character of the New Zealanders was considered more barbarous than that of any other savage nation', he continued, 'so that few would venture out to a country where they could anticipate nothing less than to be killed and eaten by the natives.' ${ }^{102}$

Eventually two 'mechanics' offered their services. Later writing of this dilemma, Yate observed:

[i]t was no small task which the Committee imposed upon themselves, to find persons of a suitable character for the undertaking; men who should be willing, with their lives in their hands, to go to the uttermost parts of the earth, to live among a strange and savage people, with whose language they were unacquainted, and of whose manners and customs, all they knew amounted but to this - that they were a nation of ferocious barbarians. ${ }^{103}$

\footnotetext{
101 Ritchie, 'sound of the bell amidst the wilds', passim

102 Marsden, 'First New Zealand Journal', Letters and Journals, p.61

103 Yate, Account, p.166
} 
The missionaries, Nicholas wrote with praise at the establishment of the mission, 'departed at the call of Religion and Humanity, to dwell in an island of cannibals, remote from their native shore as the very extremity of the globe'. ${ }^{104}$

Among the initial missionaries to Māori was Oxfordshire shoemaker and twinespinner John King. King departed England for Port Jackson aboard the Ann on 25 August 1809, accompanied by Marsden, fellow missionary William Hall, and Ngāpuhi rangatira Ruatara, who had travelled to London, fallen ill, and was seeking to return home. ${ }^{105}$ During the voyage to New South Wales, Ruatara and King developed a strong friendship, which, as J.R. Elder observed, Marsden regarded as a 'happy augury' for the future of his mission. ${ }^{106}$

The Ann docked at Port Jackson on 27 February 1810. It was, however, nearly five years before King, Hall, and the third founding missionary Thomas Kendall, who had subsequently joined them at Sydney, were able to reach the intended field of their labours. On their arrival in New South Wales the missionaries learned of the Boyd incident. The previous year the Boyd had entered Whangaroa Harbour, north of the Bay of Islands, whereupon as utu for the mistreatment of a leading member of the local hapū, all the Europeans on board, with the exception of a woman and two children, were killed and the ship cremated. This was followed by the killing of a large number of Māori who were not involved in the incident by European whalers visiting the Bay of Islands.

\footnotetext{
104 Nicholas, ii:pp.203-204

105 ibid., i:pp.39-45 \& ii:p.187n; Marsden, 'Memoirs of Duaterra', in Nicholas, ii:pp.380-397; Morton, p.166; Ormond Wilson, Kororareka \& Other Essays, Dunedin:1990, pp.30-32

106 J.R. Elder (ed.), Marsden's Lieutenants, Dunedin:1934, p.21
} 
The Boyd incident, and the misdirected retribution which followed, caused the CMS mission to Māori to be delayed, as no ship's captain could be found willing to risk his ship and crew to provide the missionaries passage to the Bay of Islands. ${ }^{107}$ As Marsden lamented:

[o]n our arrival at Port Jackson, in February, 1810, we received the melancholy news that the ship Boyd, of 600 tons burden, had been burnt, and the captain and crew all murdered and eaten by the natives of Wangarooa, in New Zealand. This most awful calamity extinguished at once all hopes of introducing the Gospel into that country. Every voice was naturally raised against the natives, and against all who were in any way attached to their interest. None lamented this calamity more than myself. ${ }^{108}$

The image of Māori as warlike cannibals was thus further entrenched. On this occasion, as had earlier been the case with the Adventure's 1773 visit to Grass Cove and the 1772 visit of the Marquis de Castries and Mascarin to the Bay of Islands, Māori violence had been directed at Europeans, reminding all that internecine Māori violence could easily be extended to Māori-European violence. ${ }^{109}$ Marsden later admitted that he had been 'afraid to send Messrs.

107 Much ink has been spilt on the Boyd incident. Here, however, Marsden's journal is quoted from as it depicts the description of events and the image of Māori circulating at the time; that this circulated information was likely hyperbolic further evinces that the European conceptualisation of Māori as violent cannibals was multifarious. See also: HRNZ, i:pp.293-312; Nicholas, i:pp.134-152 \& 298n; Richard A. Cruise, Journal of a Ten Months' Residence in New Zealand, London:1823, pp.72-75; Earle, pp.43 \& 63; Yate, Account, pp.119 \& 166-167; Polack, New Zealand, ii:pp.58 \& 165-170; Clarke (junior), Notes, pp.7-8; and more recently: Keith Sinclair, A History of New Zealand [1959], revised edition Auckland:1988, pp.36 \& 50; A.T. Yarwood, Samuel Marsden: the Great Survivor, Melbourne:1977, pp.127-128; Morton, pp.137-138 \& 269; Wilson, Kororareka, pp.32-33; Wilson, From Hongi, pp.57-58; Richard S. Hill, Policing the Colonial Frontier: the Theory and Practice of Coercive Social and Racial Control in New Zealand, 1767-1867, 2 parts, Wellington:1986, i:p.34; Belich, Making Peoples, pp.141-142, 147 \& 170; Michael King, The Penguin History of New Zealand, Auckland, 2003, p.110; Standfield, 'Warriors and Wanderers', pp.175-180

108 Marsden, 'First New Zealand Journal', Letters and Journals, p.61

109 Julien Crozet believed Māori had killed his countrymen 'in order to feast on them afterwards'. As with the Adventure and Boyd killings, the Marquis de Castries and Mascarin deaths were due to a European breach of tapu, and as with the Boyd incident, these deaths were followed by violent European retaliation; Salmond, Two Worlds, pp.387-402 \& 427-428; Belich argues that this breach of tapu, and necessary utu, were justified by a take which incorporated traditional reasons with new economic factors; Belich, Making Peoples, pp.77-78 
Hall and King lest they should kill and eat them also' ${ }^{110}$ Despite this setback, the CMS mission to Māori was eventually established in late-1814, although, as Nicholas noted, 'a sacrifice of the life of every one was foreboded', as Māori 'were represented in the Colony in the blackest colours'. ${ }^{111}$

Edited by the CMS secretaries, the Missionary Register was compiled from missionary reports from around the world. A publication known to have misquoted missionaries, ${ }^{112}$ its political agenda must be kept in mind when assessing the reliability of its content. Like missionaries in the field, the Missionary Register's editors faced the difficult task of attempting to portray indigenous peoples as 'savage' enough to need 'saving', yet not too 'savage' so as to deter readers from donating funds or dedicating their lives to living among 'savages' to affect their salvation. This was compounded by the aforementioned framework within which missionaries were writing to their London supervisors.

It was in this vein that the 1815 Missionary Register included some remarks by Kendall. 'It has been said (he observes), that "few vessels ever left the coasts of New Zealand without the loss of some part of their crew." This is a serious charge; which I cannot, however, believe to be true'. The evangelical editors further cited Kendall as declaring that while Māori 'undoubtedly retaliate with the utmost fury' when provoked, he could not 'learn that they have generally, if at any time, been the first aggressors'. 'They have, on the contrary, in a variety of cases which have been incorrectly stated in British Newspapers', the excerpt continued, 'suffered much from the tyranny and

\footnotetext{
110 Marsden, 'Second New Zealand Journal', Letters and Journals, p.206

111 Nicholas, for his part, was 'importuned by all my friends ... [to] not trust myself to the hospitality of a people so savage and inhuman, to some of whom I must eventually fall a victim' - such was the image of Māori circulating in Sydney; Nicholas, i:pp.4 \& 30

112 Judith Binney, The Legacy of Guilt: a Life of Thomas Kendall [1968], Wellington:2005, p.21
} 
wanton abuse' of visiting Europeans. ${ }^{113}$ In the early decades of the nineteenth century images of Māori being circulated in British (and colonial) ${ }^{114}$ newspapers portrayed a cannibalistic and warlike people who posed a great threat to Europeans who encountered them; images the CMS sought to moderate, though not completely dispel.

Meanwhile Māori continued to overtly display violence to European visitors. Missionaries were terrified that internecine Māori violence would be extended to Māori-Pākehā violence; sometimes the threat of this was blatant. Threats of Māori-Pākehā violence, both perceived and real, were deliberately reinforced by explicit displays of internecine Māori violence. In mid-1822, King wrote in his journal:

[d] uring last night Paroa's people slain a fine jolly young woman (tho' a slave) while asleep, for meat \&c. - about four O'clock this morning a native came to our front window, broke a pain of glass, I heard the crack \& got up went outside the native was gone I called to the natives who was sleeping on the Beach, to know who broke the window, they gave me no answer, at daybreak Paroa \& his party left this settlement to go to his place at the north-cape left the woman's head on the Beach who was slain during the night. ${ }^{115}$

King's protracted sentence - the lack of grammar an indication of his limited formal education, the busy life of a missionary with little time for writing, and perhaps the terrified emotiveness in which it was written - highlights a European fear that internecine Māori cannibalism would be extended to the consumption of Europeans.

\footnotetext{
113 Missionary Register, London:1815, p.190

114 See for example: Sydney Gazette and New South Wales Advertiser, 30 March 1811, p.3 \& 13 April 1811, p.2

115 John King, journal, 31 July 1822, MS-73, Hocken Library (HL)
} 
Although here there was no overt threat of violence, having people whom he saw as warlike cannibals near his family, and having one of these people break a window at his house, terrified the missionary. 'When I arrived here', King recalled two years before his death, 'they had no book, no letters, nor Sabbath \& was without hope, \& without God in the world'. Having lived among Māori for nearly forty years, he reflected: 'after we sat down among them, they carried on destructive wars to the east, west, north, and south, we knew not their language customs \& manners ... for several years being afraid; there was no other settlement to run to in time of danger, no ship to fly to, no escape'. ${ }^{116}$

Henry Williams reported in January 1827: ‘[o]ur situation, to all human appearances, is as uncertain as possible ... numbers would gladly avail themselves of any pretence, to seize both us and what we may possess ... [w]e are seated amongst combustible matter' ${ }^{117}$ As Dorothy Shineberg notes, Europeans who encountered Pacific peoples, from Cook to the middle of the nineteenth century, 'felt that they had a better weapon than the natives, but never that it was good enough to compensate for being greatly outnumbered or being caught unawares'.118 Europeans visited and lived in Aotearoa on Māori terms up to 1840 and beyond; something Māori knew, exploited, and sought to maintain. ${ }^{119}$

As had those who encountered the Endeavour crew and other early European explorers, Māori near the Bay of Islands mission stations were quick to learn of (or remember) the Pākehā aversion to violence, particularly cannibalism,

\footnotetext{
116 J. King to CMS secs., 10 May 1852, MS-73, HL

117 Henry Williams, The Early Journals of Henry Williams, Senior Missionary in New Zealand of the Church Missionary Society, 1826-40, Lawrence M. Rogers (ed.), Christchurch:1961, 29 January 1827, pp.41-42

118 Dorothy Shineberg, 'Guns and Men in Melanesia', JPH, 6, 1971, p.77

119 James Belich, The New Zealand Wars and the Victorian Interpretation of Racial Conflict [1986], Auckland:1998, p.20
} 
and were equally quick to utilise it. King reported on 6 November 1822: 'while I was away from home this Day sevral natives threatened to kill \& eat Mrs King \& children \& burn the House \&c. - this (tho' not the first time) had a great effect on her mind'. One of these men returned later in the month and 'beheaved \&c. so bad to me that Mrs King was afraid to be left while I went on board' a visiting ship. Such threats were reinforced by overt displays of internecine Māori violence, notably cannibalism, within sight of the mission families. In November 1823 a female slave 'was cooked and eaten at a short distance from our Houses'. Two weeks following Mrs. King's fright, John King noted bluntly: 'a slave was killed and eat for theft'. A year later he observed ' $[t]$ he natives being in such a wild state - bakeing and eating the flesh of men just outside our fence \&c. \&c.' The previous day he had noted that 'it gave our children and Mrs King a great fright - seeing and hearing so much about killing and eating so often'. ${ }^{120}$

It was later reported in the 1834 Missionary Register that '[h]uman victims used to be killed, roasted, and eaten in front of the [Kerikeri Mission] Station; and the horrible scenes were excluded only by the closed shutters of the Mission House.' 'The heads of their victims were', the report continued, 'frequently brought and stuck upon the rails in front of the doors of those houses, by way of intimidation, and the inmates were insulted and threatened with a similar fate: often were they obliged to bolt and bar their doors, and barricade themselves from the violence of hostile natives'. ${ }^{121}$ Bay of Islands Māori were eager for the missionaries to see that they were warlike cannibals in order to reinforce that the Pākehā were in the Bay on Māori terms. '[A]s soon as an opportunity is afforded', Henry Williams wrote with

\footnotetext{
120 J. King, journal, 6 \& 26 November 1822, 19 November 1823, 9 December 1822, 17 \& 16 December 1823, MS-73, HL

${ }^{121}$ Missionary Register, London:1834, p.155
} 
frustration in 1827, 'they shew their warlike propensity or rather, their thirst for blood' ${ }^{122}$

'The horrid cruelties which are practised, and the murderous exploits of which they boast', Yate observed in his Account of New Zealand, 'are far too appalling to relate to civilized man: suffice it to say, that when an opportunity presents of falling upon a small party, unprepared to withstand them, or too weak to do so, the whole are either murdered or enslaved.'123 In the winter of 1826 Clarke was told of the death of Pomare, a Ngāpuhi rangatira who had been killed while undertaking a tauā in the Waikato. ${ }^{124}$ Clarke related the tale in his journal. After waiting to ambush Pomare and his toa (warriors) on the Waipa, a 'body of natives made a sudden rush upon Pomare while he was in the act of loading his double Gun, cut him down, severed his head from his body, and drank his blood as it issued warm from him. Not content with this, they cut him up immediately, and devoured him uncooked'. ${ }^{125}$

While it is impossible to ascertain exactly what Clarke was told, it is likely that he was further exaggerating upon Māori hyperbole. As Obeyesekere suggests, Māori - 'wonderful raconteurs by all accounts' - 'exaggerated their anthropophagy in the context of Western contact ... as a weapon, as satire, as a grandiose affirmation of their greatness in war and the pathetic incompetence of their enemy'. 'The European exaggeration of Maori exaggeration', he adds, 'is based on their literalization of complex Maori discourses.' Europeans, Obeyesekere concludes, 'exaggerated Maori anthropophagy, based on

\footnotetext{
122 H. Williams, Journal, 24 February 1827, p.44

123 Yate, Account, p.134

124 Nicholas described Pomare as a man 'whose heart never seemed to incline towards the side of mercy, and who was in the literal sense of the word a cruel savage'; Nicholas, ii:p.54

125 Clarke, journal, 22 June 1826, qMS-0465, Alexander Turnbull Library (ATL); Ballara, 'Pomare I ?-1826', Dictionary of New Zealand Biography (DNZB), online edition
} 
their own fantasies'. ${ }^{126}$ Edward Jerningham Wakefield - whom Māori called Tieke owing to his unwillingness to stop talking ${ }^{127}$ - asserted that Māori 'have little shame in telling a lie; and it is no insult among them to tell a man that he is tito, or a liar'. Wakefield outlined his frustration at attempting to get Māori to understand that 'no deeper insult can be offered to a White man'. Importantly, he further observed that 'tito is also applied to improviso or inventive singing; and a famous poet among them is thus renowned as a "great liar"'.128 Nicholas, too, accused Māori of 'lying ... frequently'. 'The falsehood of these people', he further asserted, 'is seldom of a harmless nature ... they practise it only for the sake of creating alarm by some unexpected tale of fearful import, and thus rendering others miserable'. ${ }^{129}$ 'Lying', however, is an inappropriate European label applied to a Māori literary technique. As Earle observed, '[w]arlike stories were their grand desideratum'. ${ }^{130}$ Māori embellished and exaggerated military exploits, which were then further exaggerated by Pākehā commentators.

Overt displays of internecine violence and the threat of extending this to Māori-Pākehā violence served a clear purpose for Māori. In autumn 1823 King reported that two Māori men whom he had employed as sawyers 'came \& demanded pay before they had finished their work'. When King refused, on account of the work being incomplete, 'one of them began takeing the boards out of our yard \& threatened to kill my sheep \&c.' The missionary noted: 'as we have had so many threats, frights \& fears for the last year \& Mrs King being so unable to bear with me the contest of standing out

\footnotetext{
126 Obeyesekere, Cannibal Talk, pp.95 \& 109

127 Māori attempts to pronounce 'Edward' materialised as 'Era weke', which was quickly noted to sound like tīeke, the saddleback, a bird 'known for its chattering propensities'; Edward Jerningham Wakefield, Adventure in New Zealand, from 1839 to 1844; with Some Account of the Beginning of the British Colonization of the Islands, 2 vols., London:1845, i:p.91

${ }^{128}$ Wakefield, ii:p.244, italics in original

129 Nicholas, i:pp.384-385

130 Earle, p.284
} 
against their imposition I thought it best to pay them \& let them go'. Māori well knew the European fear of violence and used this to their advantage. As King concluded, 'it may be seen by this how we are under them'. ${ }^{131}$

King further frequently detailed the arrival of numerous tauā to and from the Bay of Islands in his journal. In May 1822 he wrote that 'a party came back from war, have brought a number of slaves \& Heads'. Eleven weeks later he noted 'large parties arrived here from war, they have brought a great number of slaves, Heads, \& canoes, with them, lost some of their men in battle'. One Sunday in February 1825 he reported that he had 'advised them to ... lay aside fighting \& stealing ... and observe the Sabbath Day seek wisdom and the knowledge of God'. To this one man replied: 'White men will not leave off praying, neither will Newzealand men leave off fighting'. ${ }^{132}$ While Māori could easily have kept their continued cannibalism and returns from victorious tauā hidden from the missionaries, they preferred, initially at least, to flaunt these behaviours before Pākehā to further entrench their image as warlike cannibals.

In discussing the possibility of sending more missionaries to the Bay of Islands, Marsden wrote to the CMS secretaries to soothe their fears concerning violence. Despite the incidents discussed above, and many others, Marsden wrote that he was assured by rangatira 'with respect to the main ground of the Europeans' fears - of being killed and eaten - they contended that this was altogether on our part groundless'. '[I]t was absurd to suppose', Marsden had been told, 'that they would act so contrary to their own interests as to kill and eat people who came to live quietly amongst them and introduced so many articles of real value'. Ngāpuhi rangatira had concluded by subtly

\footnotetext{
131 J. King, journal, 3 April 1823, MS-73, HL

132 ibid., 11 May \& 28 Jul 1822, and 6 February 1825, MS-73, HL
} 
letting Marsden know that the balance of power remained with them, noting 'with a smile that, if they naturally craved after human flesh, we might make ourselves easy on that head, as the flesh of New Zealanders was much sweeter than that of a European in consequence of the white people eating so much salt' ${ }^{133}$ The context in which this was written must be kept in mind. Marsden was, after all, seeking permission and funding for more missionaries. Regardless, the excerpt shows Māori purposefully maintained their image - a warlike and cannibalistic people who held the balance of power in the Māori-Pākehā relationship, but a people not so terrifying as to frighten away any contact and the trade which it enabled.

Recalling a rangatira remonstrating his people for wrestling with him upon his arrival in New Zealand, Maning wrote that the chief complained: '[i]t will be heard all over the country; we shall be called the "pakeha killers;" I shall be sick with shame; the pakeha will run away, and take all his taonga [treasure] along with him; what if you had killed him dead, or broken his bones?'134 E.J. Wakefield noted that while numerous rangatira expressed 'disinterestedness' in European trade goods other than powder, cartridges, and muskets, they declared 'their principal object was to get white people to live among them'. ${ }^{135}$ As Maning noted, Pākehā were 'considered to be geese who laid golden eggs, and it would be held to be the very extreme of foolishness and bad policy either to kill them, or, by too rough handling, to cause them to fly away'. ${ }^{136}$

\footnotetext{
${ }^{133}$ Markham was informed by the missionary wife Mrs. Kemp that 'Europeans are not considered so good eating at the Mouries as they are too Salt, but it is no protection to them, as they delight in having a Hungry dance round a fellow'. Markham later added 'Sailors the Gourmands pronounce to be too tough and Salt, and not so good as Mouries but still are eatable with a good appetite as Sauce and well done Potatoes'; Marsden, 'Second New Zealand Journal', Letters and Journals, p.214; Markham, pp.71 \& 79

134 Maning, Old New Zealand, pp.34-35, italics in original

135 Wakefield, i:p.89

136 Maning, Old New Zealand, p.184
} 
Despite the assurances of Marsden and others, the image of Māori circulating in Europe remained one of warlike cannibals. In the context of complaining to his parents that they had not written to him for nearly two years, in August 1827 Clarke observed 'I do not doubt but you have long ago heard that we were all eaten up by the N. Zealanders'. But for the grace of God, he concluded, 'we should have been long ago'. Clarke reiterated his point later the same year: 'I daresay, dear Father, you have heard rumours about us, and perhaps have seen in print that we have been swallowed up'. ${ }^{137}$ The violent portrayal of Māori circulating in Europe, which the missionaries sought to counter, was simultaneously reiterated by the evangelicals. Early in 1825 Clarke observed: 'New Zealand, my dear Father and mother, and the natives thereof, remain much the same; savage and warlike disposi[ti]ons are the predominant features of a New Zealander. They actually thirst for blood, and glory in portraying their cruelty'. '[O]ne of the most savage nations in the world, whose glory is in war and blood', he concluded, 'the very message of peace is disgusting to a New Zealander' ${ }^{138}$

Incorporated into the European conceptualisation of Māori violence was the portrayal of Māori infanticide. Ian Pool notes that '[i]nfanticide and its companion, induced abortion, occur in every society', and infanticide is thought to have been reasonably common in late-eighteenth- and early-nineteenthcentury Britain. ${ }^{139}$ In 1739 London's Foundling Hospital was established, among other reasons, in response to the 'frequent Murders committed on

\footnotetext{
137 Clarke to his parents, 22 August \& 7 November 1827, MS-Papers-7394, ATL

138 ibid., 6 January 1825, MS-Papers-7394, ATL

139 Ian Pool, Te Iwi Maori: a New Zealand Population Past, Present \& Projected, Auckland:1991, p.47; Sauer, pp.81-85
} 
poor Miserable Infant Children at their Birth by their Cruel Parents'. ${ }^{140}$ During the nineteenth century, owing to the difficulty of procuring evidence of infanticide, secret childbirth was made a criminal offence in Britain if the child died during or soon after birth by the charge of concealment; the harsh penalties associated with the crime were intended to discourage infanticide by categorising women who sought to hide pregnancy as potential murderers. $^{141}$

Europeans encountered and conceptualised Māori (and Aboriginal) infanticide at a time of much discussion of, and investigation into, the practice in Britain. Although a reasonably frequent occurrence, infanticide was illegal and was certainly considered deplorable behaviour. British women also had access to abortion during this period - considered a mortal sin but, unlike infanticide, not a serious legal offence. ${ }^{142}$ Replying to critics' claims that an elimination of the availability of support for children born out of wedlock would lead to a rise in infanticide, it was exclaimed in the 1834 parliamentary Report of the Commission on the Poor Laws: '[w]e do not believe that infanticide arises from any calculation as to expense. We believe that in no civilised country, and scarcely any barbarous country, has such a thing been heard of as a mother killing her child in order to save the expense of feeding

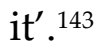

Early-nineteenth-century British infanticide tended to be carried out by smothering, poisoning, dropping, deliberately neglecting, or abandoning a child. ${ }^{144}$ These methods were private and difficult to prove in court, particularly, as Ann Higginbotham suggests, 'in the anonymity of a great city' such

\footnotetext{
140 quoted in Sauer, p.81

141 Hunt, pp.71-94; Higginbotham, p.327

142 Sauer, pp.83-84

143 quoted in Hunt, p.72

144 Sauer, pp.81-82
} 
as London. ${ }^{145}$ This concealed infanticide starkly contrasted with the more visible forms of Māori infanticide encountered by European settlers. ${ }^{146}$ Māui, the hero of many Māori legends, had survived attempted infanticide: as a baby he was wrapped in his mother Taranga's topknot and thrown into the sea. ${ }^{147}$ Infanticide, like cannibalism, was a natural aspect of late-eighteenthand early-nineteenth-century Māori life, although, as Pool suggests, it was not as frequent nor as female-focused as was once thought. ${ }^{148}$ Māori occasionally partook in infanticide for the same reasons peoples of the world over did, and for many of the same reasons people use contraception or practice abortion, adoption, or whāngai (customary adoption) today.

Julien Marie Crozet, Marion du Fresne's second-in-command, assumed infanticide upon first encountering Māori in 1772. 'On the whole I did not see many children', he noted, adding '[a]t sight of these big, hardy and wellmade men, one suspects that they do not preserve those children who are born sickly or deformed'. ${ }^{149}$ Half-a-century later, King wrote of a slave who gave birth to a female child at Rangihoua. '[S]he struck it on the top of the Head with her fist killed it \& buried it', he reported, 'many Females do not like the Trouble of Infants \& destroy them before they are brought forth'. Invoking the warlike image of Māori, the missionary concluded: 'Female Infants are often killed as they are not accustomed to war' ${ }^{150}$ The following year Marsden related the story of a Māori woman killing her newborn son. He asserted that this instance of infanticide was due to the mother's jealousy

\footnotetext{
145 Higginbotham, p.319

146 Wilson, From Hongi, p.68

147 Māui also practised cannibalism; Walker, pp.15-16; Polack, New Zealand, i:p.358

148 Pool, pp.47-48

149 Julien Marie Crozet, Crozet's Voyage to Tasmania, New Zealand, the Ladrone Islands, and the Philippines in the Years 1771-1772, Henry Ling Roth (translation), London:1891, p.66

150 J. King, journal, 22 September 1822, MS-73, HL; see also: Skinner to Bigge, 12 September 1820, HRNZ, i:p.539; Earle, p.244; Markham, p.83n; Polack, New Zealand, i:pp.380-383; Polack, Manners and Customs, ii:pp.93-94
} 
at her husband having two wives. 'Infant murder is not common in New Zealand, and particularly boys', he concluded. 'They are fond of their children, and take great care of them'. ${ }^{151}$

Writing in 1835, Yate noted his belief that ' $[\mathrm{t}]$ he quarrels of the women have very often been the cause of infanticide; which at one time, through jealousy, existed to an alarming extent in' New Zealand. He wrote that it had been his 'painful lot to be an eye-witness of several cases of infanticide'. To this, elucidating the complex image of Māori as warlike cannibals who practiced infanticide held by many Europeans, he added a footnote: '[i]t is not true, as represented in a recent publication, that New-Zealand mothers eat their own children. This is too horrible, even for them!'152 For King, Marsden, Yate, and many other commentators, infanticide and the warlike nature of Māori were inextricably linked; however frequently the practice of killing one's own child occurred, Europeans agreed that it was more often female children who were killed.

Belich has shown that the European conceptualisation of Māori domestic relations was convoluted. ${ }^{153}$ In contrast to the other side of the Tasman world, Māori domestic gender relationships were perceived by Europeans as primarily non-violent. As noted at the beginning of this chapter, Banks concluded Māori men and women were 'very affectionate to each other'. On his first visit to New Zealand Marsden 'saw no quarrelling nor domestic broils'. 'They are kind to their women and children', he further wrote. 'I never observed a mark of violence on any of them, nor did I see a woman struck'.

\footnotetext{
151 Marsden, 'Fourth New Zealand Journal', Letters and Journals, p.371

152 Yate, Account, pp.98-99 \& 98n

153 Belich, Making Peoples, pp.99-105; Belich, 'Race and New Zealand', p.16
} 
Marsden's missionaries agreed with his observations. ${ }^{154}$ Yate believed Māori children to be 'spoiled' - 'a great plague' the Calvinist-influenced evangelical sought to remedy. ${ }^{155}$ Contrasting yet coexisting with the image of Māori as warlike cannibal 'savages' was a peaceful portrait of Māori domestic relations.

As well as missionaries and explorers, pre-1840 European visitors to New Zealand included many runaway sailors, escaped convicts, whalers, and sealers, and these men also interacted with Māori. Europeans began whaling in the seas surrounding New Zealand around 1801. Sealing, 'related to whaling in personnel and product', began on the islands off New Zealand in the late-eighteenth century, from where it quickly spread to the southern mainland following the decline of the Bass Strait seal population c.1803. Following the sealers, by 1827 shore-based whaling stations had been established along the New Zealand coast. ${ }^{156}$ As Harry Morton has shown, sealers and whalers were among the first Europeans to interact with Māori for prolonged periods. ${ }^{157}$ Few whalers or sealers, however - with the notable exception of John Boultbee, who chronicled his experiences sealing during the twilight of the period - recorded accounts of their endeavours and their perceptions of Māori. ${ }^{158}$ As Ormond Wilson notes, Marsden's and Nicholas' ac-

\footnotetext{
154 Marsden, 'Observations on the Introduction of the Gospel into the South Sea Islands: Being my First Visit to New Zealand in December 1814', HRNZ, i:p.396; see also: Marsden, 'Fourth New Zealand Journal', Letters and Journals, p.407

${ }^{155}$ Yate, Account, p.241; see also: Savage, pp.44-45

156 Morton, pp.16-17, 105 \& 110; Peter Adams, Fatal Necessity: British Intervention in New Zealand, 1830-1847, Auckland:1977, pp.27-29; Belich, Making Peoples, pp.130-139; Polack, New Zealand, i:p.49

157 Morton, pp.63 \& 107

158 ibid., p.111; Boultbee, passim; Angela Wanhalla, In/visible Sight: the Mixed-Descent Families of Southern New Zealand, Wellington:2009, pp.7 \& 30
} 
count of their ten-week visit in 1814-1815 'jointly present the first coherent account of Māori society since Cook's journals thirty odd years earlier' ${ }^{159}$

Nicholas published his account of his visit to New Zealand with Marsden because he believed that since Cook's visits, New Zealand had 'been almost entirely neglected'. His book, first published in English in 1817, was further translated into Dutch and German in 1819. Those Europeans who had visited between Cook and himself Nicholas described as men 'of callous hearts, who were as little disposed to conciliate the friendship of the rude inhabitants, as they were to pay a due regard to their own character'. Additionally, he continued, 'the odium thrown on the natives themselves, by being viewed as ferocious cannibals, served, as it were, to interdict any cordial communication with them'. 'Dreaded by the good, and assailed by the worthless', Nicholas concluded, 'their [Māori] real dispositions were not ascertained; the former dared not venture to civilize them, the latter only added to their ferocity.' 160

In 1827 Earle wrote of men residing in New Zealand 'whose downcast and sneaking looks proclaim them to be runaway convicts from New South Wales'. ${ }^{161}$ In 1839 the log-keeper of the American whaler William Hamilton described New Zealand as 'this half sivilized runaway convicts place of Englishmen ... no better than pirats'. ${ }^{162}$ Soon after, New Zealand Company propagandist E.J. Wakefield described New Zealand shore-whalers as 'a mixture of runaway sailors and escaped convicts'. ${ }^{163}$ There is a notable gap in the conceptualisation of Māori violence from whalers and sealers, from

\footnotetext{
159 Wilson, Kororareka, p.38

160 Nicholas, i:pp.1-2

161 Earle, pp.52-53; see also: Ivan P. Kerbel, 'Notorious: a History of Kororāreka and the New Zealand Frontier, c.1800-1850', MLitt thesis, University of Auckland:1998, pp.15 \& 61-62

162 cited in Morton, p.157

163 Wakefield, p.48
} 
runaway convicts and deserters - 'that class who never could quite remember to a nicety how they came into the country, or where they came from ${ }^{\prime 164}$ but many of these men had very limited literacy and were thus unable to write accounts of their encounters, and those who were escapees were hardly likely to have written accounts of their newly free lives, even had they been able to. ${ }^{165}$ Nevertheless, the stories they told in the taverns of the Rocks and elsewhere likely influenced the conceptualisation of Māori as warlike, cannibal 'savages'.

The European conceptualisation of Māori violence was one of fascination often respect, repulsion, and revulsion combined. Māori were well aware of this European enthralment with their customs and practices involving violence and actively exploited it to their benefit, both through explicit threats and through internecine actions knowingly and intentionally conducted in view of a European audience.

Europeans grasped this image which was being flaunted for their benefit; thus an image of Māori as warlike, cannibal 'savages' was established during the late-eighteenth and early-nineteenth centuries through a combination of European fear and fascination, and, of equal significance, a Māori desire to be perceived as warlike cannibals. This conceptualisation of Māori violence is multifarious. Although cannibalism was entwined within the construction of the image of Māori as warlike and deplored, Māori violence was often admired, or at least respected, by Europeans. As Belich observes, 'the war-

\footnotetext{
164 Maning, Old New Zealand, p.66

165 Boultbee, the proverbial exception to the rule, 'was acutely conscious that his upbringing and education set him apart from his fellows as he recalled his thoughts and experiences shared with tough and illiterate sealers'; Starke, 'Introduction', p.xxxvi
} 
like label was originally intended as a compliment, though a loaded one'. ${ }^{166}$ Positive images of Māori survived the representation of Māori as cannibals.

K.R. Howe notes that 'Europeans' initial reactions to Aboriginal and Maori societies tended to set the tone for future racial attitudes in Australia and New Zealand.'167 In discussing Cook's encounter with Aborigines, Belich suggests that ' $[t]$ he Aboriginals were never forgiven for their disinterest in Europe.'168 Michael King, among others, argued that it was, among other factors, the already established image of Māori as warlike which led to the British penal settlement being established in New South Wales rather than New Zealand: 'Aboriginal people were assumed to be less martial than Maori, less organised and vigorous, and therefore easier to control in the operation of a colonial enterprise'. ${ }^{169}$ The conceptualisation of Māori as 'a most warlike people' had a pervasive influence on the contrasting colonial (and later) histories experienced in the Tasman world, as is further explored in the following sections.

166 Belich, Making Peoples, p.75

167 Howe, Race Relations, p.11

168 Belich, Making Peoples, p.148

169 M. King, Penguin History, pp.113-114; Belich, Making Peoples, p.129; Hill, Policing the Colonial Frontier, i:pp.29-30 


\section{Chapter Three \\ '[T]o encircle them in the arms of protection': the Suppression of Aboriginal Violence}

Among the more concentrated attempts to suppress Aboriginal violence in Australia during the nineteenth century were the philanthropic efforts to 'civilise' and Christianise the Aboriginal peoples of Port Phillip, from soon after first settlement to mid-century. ${ }^{1}$ Following the Australian frontier southwest across the Murray River then, in this chapter the focus shifts from New South Wales proper to the Port Phillip District of New South Wales, which became the colony of Victoria upon its separation in 1851.

In order to fulfil their aim of 'civilising' and Christianising the Aboriginal population of Port Phillip, philanthropists and other agents of colonisation deemed it necessary to restrain Aboriginal violence. A key part of this philanthropic effort was the establishment of the Aboriginal Protectorate, which, with additional information drawn from contemporary evangelical missionary experiences, is the main focus of this chapter. Although missionaries were church-appointed while protectors were appointed by the Crown, like their counterparts in New Zealand the two groups of philanthropists had much in common. Both relied on government grants of land and money, both had often strained relationships with colonial administrators, both were heavily condemned by settlers, and both sought the 'civilisation' and Christianisation of Aborigines. ${ }^{2}$

Preceding the beginning of European settlement in Port Phillip in 1834, in Britain Catholics had their political rights restored (1829), the Reform Bill

\footnotetext{
${ }^{1}$ Foxcroft, passim, esp. pp.6 \& 55

2 Jessie Mitchell, 'A City on a Hill": Aboriginal Missions and British Civilisation, 1830-1850', in Kate Darian-Smith et al. (eds.), Exploring the British World: Identity, Cultural Production, Institutions, Melbourne:2004, pp.223-236
} 
was passed (1832), and slavery was abolished throughout the Empire (1833). These significant developments were followed by the British House of Commons assembling a select committee (1835-1837) to report on the conditions of indigenous peoples and colonial policies regarding them in British possessions and other places 'continually visited by Subjects of Great Britain'; notably Canada, Newfoundland, New South Wales, Van Diemen's Land, New Zealand, the South Sea Islands and, where the committee's attention was most intensely focussed, southern Africa. Building upon the works of Elizabeth Elbourne, Zoë Laidlaw, and Alan Lester and Fae Dussart - historians who focus on the transnational nature of the investigations and findings of the select committee and its influence over philanthropic efforts throughout the Empire - both this chapter and the one following see the select committee and the Aboriginal Protectorates it recommended and influenced as important transnational initiatives which influenced attempts to suppress indigenous violence in the Tasman world. ${ }^{3}$

Specifically, the select committee was appointed:

to consider what Measures ought to be adopted with regard to the Native Inhabitants of Countries where British Settlements are made, and to the neighbouring Tribes, in order to secure to them the due observance of Justice and the protection of their Rights; to promote the spread of Civilization among them, and to lead them to the peaceful and voluntary reception of the Christian Religion.

In August 1836 and June 1837 the findings and recommendations of the select committee were published in a two-volume report which ran to over a

\footnotetext{
${ }^{3}$ Elizabeth Elbourne, 'The Sin of the Settler: the 1835-36 Select Committee on Aborigines and Debates over Virtue and Conquest in the Early Nineteenth-Century British White Settler Empire', Journal of Colonialism and Colonial History, 4:3, 2003, np; Zoë Laidlaw, Colonial Connections, 181545: Patronage, the Information Revolution and Colonial Government, Manchester:2005; Zoe Laidlaw, 'Integrating Metropolitan, Colonial and Imperial Histories - the Aborigines Select Committee of 1835-37', in Banivanua Mar and Evans (eds.), pp.75-91; Lester and Dussart, 'Trajectories of Protection', pp.205-220
} 
thousand pages. ${ }^{4}$ As this publication corresponded with the beginning of European settlement in Port Phillip, colonial administrators decided that a number of the committee's suggestions should be implemented in the fledgling district.

The select committee reaffirmed that Aborigines were subjects of the British Crown, noting that they 'must be considered as within the allegiance of the Queen, and as [such] entitled to her protection'. 'If the whole of New Holland be part of the British Empire', they asserted,

then every inhabitant of that vast island is under the defence of British law as often as his life or property may be attacked; and the appeal to arms for adjusting controversies with any part of the primitive race, exposes those by whom blood may be shed to the same responsibility, and to the same penalties, as if the sufferers were white persons.

The committee conceded, however, that ' $[t]$ o require from the ignorant hordes of savages ... the observance of our laws would be absurd, and to punish their non-observance of them by severe penalties would be palpably unjust'. 'On the other hand', they continued, 'if they are placed beyond the pale of the law as a rule of their conduct to others, they will infallibly lose the advantage of it, considered as a rule of conduct of others towards them.'

The select committee thus advised that it was the duty of the colonial government, under the advice of appointed protectors of Aborigines, to decide to what degree and how indigenous violence should be suppressed in Australia. These protectors were to suggest to the colonial government 'such short and simple rules as may form a temporary and provisional code for the regulation of the Aborigines, until advancing knowledge and civilization

\footnotetext{
${ }^{4}$ Report from the Select Committee on Aborigines, i:p.iii \& ii:p.3
} 
shall have superseded the necessity for any special laws'. ${ }^{5}$ Following these recommendations an Aboriginal Protectorate was thus established, at the direction of Secretary of State for Colonies Lord Glenelg, by New South Wales Governor Sir George Gipps in the Port Phillip District in late-1837.

In this chapter it is argued that philanthropists saw the suppression of Aboriginal violence as necessary for the 'civilisation' and Christianisation of Aboriginal peoples, and, relatedly, for effective colonisation. Much church and government effort dedicated to Aboriginal peoples in Port Phillip was directed at the attempted suppression of Aboriginal violence - particularly inter-language group conflict - in accordance with these imperatives. It is further argued that such attempts at suppressing internecine violence largely failed; and that, in fact, missionaries and protectors of Aborigines often actually exacerbated the very Aboriginal violence they sought to suppress. Meanwhile, having their efforts to suppress Aboriginal violence using their supposed status as British subjects frustrated, philanthropists attempted to use their overarching aim of 'civilising' and Christianising Aboriginal peoples as a means of achieving their goal of suppressing Aboriginal violence. Thus a paradox developed: to become 'civilised' Christians Aborigines had to end their violence, which missionaries and protectors sought to end by 'civilising' and Christianising Aborigines.

$a$

In 1822, to encourage wool production in New South Wales, the British government slashed the duty on wool imported from the colony to one-sixth that paid on German wool. Broome suggests that this drop led directly to over 200,000 British migrants arriving in Australia during the period 1832-

\footnotetext{
${ }^{5}$ ibid., ii:pp.83-84
} 
1850 - hyperbolic perhaps, as Belich has revised the importance of sheep in the Tasman colonies' $1828-1842$ boom, but pastoralism was certainly important to the colonisation of Port Phillip. ${ }^{6}$ Regardless of the causes, Port Phillip did boom, and with the boom came a mass influx of people and sheep. G.S. Forth has outlined when and through whom news of the prime pastoral lands of the Port Phillip District reached Van Diemen's Land and New South Wales proper. ${ }^{7}$ Following these reports, and their extended circulation in Europe, between 1836 and 1840 some 11,000 Europeans arrived in the Port Phillip District; in 1840 fewer than half (4500) of them lived in the township of Melbourne. The following year another 10,000 Europeans arrived - fourfifths of them assisted migrants - nearly doubling the district's European population. When Port Phillip separated from New South Wales and became the colony of Victoria in 1851, the European population of the new colony was 77,345, and 391,000 of their cattle and a staggering 6,590,000 sheep roamed the area, the latter greatly contributing to the $40,000,000$ pounds of wool being exported from Australia annually at that time. ${ }^{8}$

Fuelled by active Aboriginal resistance, the conceptualisation of Aborigines as violent 'savages', and the fear of Aboriginal violence this image fed (discussed in chapter one), did to some extent retard European expansion in Port Phillip. ${ }^{9}$ Despite this, by 1861 some 540,000 Europeans effectively occupied

\footnotetext{
${ }^{6}$ Broome, Aboriginal Australians, p.37; Tony Barta, "'They appear actually to vanish from the face of the Earth." Aborigines and the European Project in Australia Felix', Journal of Genocide Research, 10:4, 2008, pp.524-526; Belich, Replenishing the Earth, pp.261-278 \& 357

7 G.S. Forth, 'The Pastoral Expansion and the Initial Occupation of "Australia Felix"', JRAHS, 70:1, 1984, pp.22-23; see also: Barta, pp.519-520; A.G.L. Shaw, A History of the Port Phillip District: Victoria Before Separation [1996], Melbourne:2003, pp.32-66

${ }^{8}$ G.B. Vasey, 'John Walpole Willis, the First Resident Judge of Port Phillip', VHM, 1:2, 1911, p.43; Diane E. Barwick, 'Mapping the Past: an Atlas of Victorian Clans, 1825-1904, Part 1', AH, 8:2, 1984, pp.108-109; Michael Cannon, Who Killed the Koories? The True, Terrible Story of Australia's Founding Years, Melbourne:1990, p.2; A.G.L. Shaw, 'Aborigines and Settlers in the Port Phillip District 1835-1850', La Trobe Journal, 61, 1998, p.6; C.M.H. Clark, A History of Australia, 6 vols., Melbourne:1962-1987, iii:pp.120-122 \& iv:pp.57-58

${ }^{9}$ For example the reported killing of explorers J.T. Gellibrand and G.B.L. Hesse by Aborigines in early-1837; Thomas Learmonth, 11 August 1853, in Bride (ed.), Letters from Victorian Pioneers, p.94;
} 
Victoria in its entirety, excepting only the mountains and the 'uninhabitable' Mallee country, in what Broome describes as 'possibly the fastest land occupation in human history' ${ }^{10}$ Often it was Aborigines themselves who had shown Europeans where the good grasses and water were located, only to be banished from their lands in return for their vital assistance. One group complained to the chief protector of Aborigines in 1841: ' $t$ they were poor now White men had taken their good country, no ask for it but took it. Black men show white men plenty grass, and water and then White men say be off come be off and drive them away and no let him stop' ${ }^{11}$ Early the previous year the chief protector had estimated 'half the runs have been shewn by' Aborigines, further noting ' $[t]$ hey have been employed as guides to exploring parties - and searches after land and when the purpose of the whites have been served the natives have been turned adrift - away - and frequently in a strange country \& destroyed by the other natives'. ${ }^{12}$ The abandonment of Aboriginal guides in foreign country further led to increased Aboriginal violence.

The European invasion of the Port Phillip District greatly exacerbated intraAboriginal violence in two key ways. Firstly, many Aborigines were driven onto the country of other language groups by European expansion. And secondly, many Aborigines traversed foreign country to seek out Europeans and the new goods and experiences they offered, often settling semi-

Peter Corris, Aborigines and Europeans in Western Victoria, Canberra:1968, pp.55-56 \& 59; Jan Critchett, A 'Distant Field of Murder': Western District Frontiers 1834-1848, Melbourne:1990, pp.2829 \& 47-50; Christie, pp. 60 \& 69

10 Richard Broome, 'Aboriginal Workers on South-Eastern Frontiers', Australian Historical Studies, 26:103, 1994, p.211; Broome, Aboriginal Victorians, p.54; Barta, pp.519-539; Christie, p.58

11 Robinson, journal, 17 September 1841, cited in Reynolds, This Whispering, pp.50-51; see also: Robinson to La Trobe, 09 April 1842, cited in Corris, p.98n; Henry Reynolds, With the White People: the Crucial Role of Aborigines in the Exploration and Development of Australia, Melbourne:1990, pp.5-40; Henry Reynolds, 'The Land, the Explorers and the Aborigines', Historical Studies, 19:75, 1980, pp.213-226; Broome, Aboriginal Victorians, p.55

12 Robinson, journal, 13 January 1840, MS-9974, State Library of Victoria (SLV) 
permanently on the country of another language group to improve access to these. As examined in chapter one, such contact with foreign language groups was often countered with violence. Of course, many Aborigines remained in their own country, where they encountered, and sometimes resisted, European encroachment.

In the winter of 1839 Orton wrote to the WMS secretaries bemoaning that not only was the colonial government 'fast disposing' of Aboriginal peoples' lands, but that it had further introduced the Squatters Act, 'under which settlers may establish themselves in any part of the extensive territory of New South Wales, and no reserve whatever of land is made for the provision of the natives'. Those Aborigines who remain in their own country, Orton observed, 'become pilfering - starving - obtrusive mendicants, and after enduring incalculable depravities, abuses and miseries will gradually pine away die away - and become extinct'. Those who left their country in the face of European invasion 'must encroach upon the boundaries of other hostile tribes, by whom they will be murdered and exterminated'. ${ }^{13}$

'The sheep, cattle, and horses, and indeed every animal that has ever been sent over, thrives in an extraordinary manner', Port Phillip merchant Thomas Winter gleefully reported soon after the beginning of European settlement in the district. 'Lambs three months old weigh as much as their mothers, while the cows are like fatted beasts. ${ }^{14}$ In order to become so extraordinary, however, European-introduced sheep and cattle ate native grasses 'luxuriant herbage' as one assistant protector described them ${ }^{15}$ - which sustained native game, ate and trampled the murnong (daisy yam), a vital food

\footnotetext{
${ }^{13}$ Orton to WMS secs., 13 May 1839, HRV2A, p.120; for opposing critiques of the Squatters Act see: Sydney Monitor, 10 August 1833, p.2 \& 22 February 1837, p.3; Australian [Sydney], 21 March 1839, p.3

${ }^{14}$ Winter to William Swainson, c.1837, in Bride (ed.), Letters from Victorian Pioneers, pp.394-395

${ }^{15}$ Dredge to Hardin, 12 September 1840, MS-5244, SLV
} 
source for Aborigines, and muddied and defecated in water sources essential to both Aborigines and their traditional game foods. A Ngurraiillam man named Moonin Moonin informed an assistant protector in late-1839: 'too many "Jumbuck" (sheep) and "Bulgana" (Bullocks, Cattle) plenty eat it murnong - all gone murnong. ${ }^{16}$ With their native grasses destroyed and their waterholes ruined, and with the increased danger faced from European firearms, the kangaroo, emu, and bush turkey - all crucial Aboriginal foods fled. ${ }^{17}$

In the wake of the flight of their mobile foodstuffs and a diminution of those immobile, Aboriginal peoples faced a difficult choice. They could either adapt to incorporate European-introduced foods into their diet, and face the pastoralists' wrath, or follow their traditional foods into foreign country, and face the wrath of unknown or enemy language groups. The pastoral invasion of Port Phillip increased both Aboriginal and European-Aboriginal violence.

In December 1839 squatter Niel Black reported back to his native Scotland that 'the natives who have not been brought into subjection have a strong propensity to spearing and stealing sheep and cattle, and the settlers agree that lead is the only antidote that effectually cures them of this propensity' ${ }^{18}$ In the Port Phillip Patriot it was reported that blame for the loss of sheep, whether through carelessness, accident, or actual theft, was 'instantly laid upon the natives, and armed parties are sent in pursuit, and in most cases,

\footnotetext{
16 Dredge, diary, 6 December 1839, MS-5244, SLV; R. Dredge, 'An awful silence reigns', p.23; see also: Dredge, Brief Notices, p.14; Foster Fyans, nd, in Bride (ed.), Letters from Victorian Pioneers, p.191

17 Broome, 'Aboriginal Workers', p.209; Broome, Aboriginal Australians, p.38; Broome, Aboriginal Victorians, pp.20-21; Barta, p.528; T.M. O'Connor, 'Edward Stone Parker: Pioneer and Protector', Heritage, 15, 1963, p.8; Jan Penney, 'Murrundi Aborigines and Murray Squatters', VHM, 60:1, 1989, p.42; Critchett, pp.52-67

${ }^{18}$ Niel Black, journal, 9 December 1839, MS-11519:Box-99/1, SLV
} 
such is the thirst for blood - blood of the unresisting - that they seldom return until they are satisfied with human gore'. The chief protector agreed, later noting '[1]osses of stock, whether stolen or strayed (in most instances) are charged on the Blacks some by mistake others intentional.'19 'Would these Men-hunters show so much eagerness for the chase', a Port Phillip Patriot writer further questioned, 'if the Blacks were really as cunning, cruel, and cannibalistic' as was claimed $?^{20}$

Further to the problems of accessing traditional foodstuffs brought about by European settlement, Aboriginal resistance to settlement - which often took the form of economic disruption rather than overt violence - led to European reprisals, further prompting forced Aboriginal migration. ${ }^{21}$ As squatter E.M. Curr recalled, '[t] he tribe, being threatened with war by the White stranger, if it attempts to get its food in its own country, and with the same consequences if it intrudes on the lands of a neighbouring tribe, finds itself reduced to make choice of certain death from starvation and probable death from the rifle, and naturally chooses the latter.'22 Curr's observation only hints at the complexity of Aboriginal notions of country and fails to allow for a range of responses, but it does demonstrate the plight faced by Aboriginal peoples in the wake of the European invasion of Port Phillip - either flee and face the violence of other Aborigines, or stay and face the violence of Europeans.

\footnotetext{
${ }^{19}$ Robinson, 1 August 1841, Clark (ed.), 'In Quest of the Tribes', p.117

${ }^{20}$ Port Phillip Patriot and Melbourne Advertiser, 15 August 1839, p.4, SLV, emphasis in original; see also: Edward White to Lonsdale, 12 February 1839, VPRS-13172, unit-1:disc-1, Public Records Office of Victoria (PROV); Sievwright, 'Minutes of Journeys made, Cases Enquired into, and the Result of such Enquiries from March to August 1839 Inclusively', 1 September 1839, VPRS-13172, unit1:disc-1, PROV

${ }^{21}$ Lyndall Ryan, 'Settler Massacres on the Port Phillip Frontier, 1836-1851', Journal of Australian Studies, 34:3, 2010, pp.257-273

${ }^{22}$ Curr, Australian Race, i:pp.103-104
} 
In January 1840 Mr. Munro, a squatter on land near the Campaspe and Colliban Rivers, informed the chief protector and one of his assistants that eighteen months previous 'there was millions of murnong ... all over the plain', and that emu and kangaroo were abundant. However, Munro continued, 'now there are none seen - the sheep drive them away'. 'This is a proof', the chief protector concluded, 'that the natives have been deprived of a large portion of their support and subsistence' ${ }^{23}$ With their traditional game fast disappearing, many Aborigines turned to the newly arrived food-animals which helpfully happened to be easier to catch and kill. As a number of Aborigines later told the chief protector, they 'stole' sheep because Europeans had stolen their kangaroo. 'Long time ago, they had plenty of kangaroo, Parm-pun, Tuerer-corn [roots] ... and then they were not hungry and did not take sheep', the chief protector was told. But now '[k]angaroo all gone, jumbuc ... eat the roots'. ${ }^{24}$ As early as March 1839 one assistant protector reported 'the aborigines were necessarily greatly distressed for food, owing to the destruction of the "murning", a ... plant formerly covering the plains of this country, but now entirely cropped off by the sheep and cattle'. ${ }^{25}$ When Tuckfield scolded a number of Djargurdwurung who were visiting his Bunting Dale mission station for taking settlers' sheep, '[t]hey acknowledged the[y] had stolen a few not many \& they did it when they were very hungry' $^{\prime 26}$

In the wake of the disruption to Aboriginal life brought about by invasion, many Aborigines sought out Europeans - philanthropic and not - for access to the new foods, stimulants, and other goods contact offered, or for the mere

\footnotetext{
${ }^{23}$ Robinson, journal, 22 January 1840, MS-9974, SLV

24 Robinson, 20-25 July 1841, Clark (ed.), 'In Quest of the Tribes', p.114

25 Parker to Robinson, 16 March 1839, VPRS-13172, unit-1:disc-1, PROV; see also: Parker to Robinson, 20 June 1839, VPRS-13172, unit-1:disc-5, PROV; Sievwright, 'Report of Proceedings from March to August 1839 Inclusively', 1 September 1839, VPRS-13172, unit-1:disc-8, PROV

${ }^{26}$ Francis Tuckfield, journal, 15 December 1839, MS-7667:Box-665, SLV
} 
novelty of encountering a new people. As Broome observes, 'Aboriginal people were attracted to Melbourne in the same way that hunters and gatherers had always moved to the most accessible food sources.' ${ }^{27}$ This frequently required travelling onto or through other language groups' country, and this often increased inter-language group violence. ${ }^{28}$

The other option available to Aborigines facing starvation or being shot by Europeans was to join their kangaroo, emu, and bush turkey in fleeing European settlement and pastoralism. This alternative, however, involved a complex decision. Aboriginal connection with country, elucidated by the Dreaming, was a principal facet of Aboriginal life, and permanently leaving one's country was an abhorrent and near-incomprehensible idea in traditional society. Aboriginal love of country encompassed both a spiritual and an economic relationship - as Broome observes 'the land not only gave life; it was life' ${ }^{29}$ Despite this, and that leaving one's country further required moving into the country of unknown or enemy language groups, with their traditional food supplies rapidly diminishing, conflict with hostile settlers increasing, and access to their sacred sites evermore restricted, many Aborigines were forced to do the previously unthinkable. The violent results of this forced migration were known to philanthropists.

\footnotetext{
27 Broome, Aboriginal Victorians, p.18; Henry Reynolds, 'The Other Side of the Frontier: Early Aboriginal Reactions to Pastoral Settlement in Queensland and Northern New South Wales', Historical Studies, 17:66, 1976, pp.60-62

28 Beverley A. Blaskett, 'The Aboriginal Response to White Settlement in the Port Philip District, 1835-1850', MA thesis, University of Melbourne:1979, pp.157-191; Broome, 'Struggle for Australia', p.120; Reece, 'Inventing Aborigines', p.14; Langton, 'Rum, Seduction and Death', p.196; Denise Gaughwin and Hilary Sullivan, 'Aboriginal Boundaries and Movements in Western Port, Victoria', $A H$, 8, 1984, pp.80-98; Susanne Davies, 'Aborigines, Murder and the Criminal Law in Early Port Phillip, 1841-1851', Historical Studies, 22:88, 1987, p.325; Broome, Aboriginal Victorians, pp.28-29; Critchett, pp.37-38 \& 96

29 Broome, Aboriginal Australians, p.14, emphasis in original; Broome, Aboriginal Victorians, p.79; Foxcroft, p.16; Mitchell, 'Country Belonging to Me', np; Critchett, p.41
} 
Following Orton's assertion that Aboriginal peoples who were forced into the country of others would be killed, in June 1841 Tuckfield extrapolated on his superior's observation. 'The Government is fast disposing of the land occupied by the natives for time immemorial', he lamented.

In addition to which settlers under the sanction of Governors may establish themselves in any part of this extensive territory and since the introduction of numerous flocks and herds ... a serious loss has been sustained by the natives without an equivalent being rendered there [sic] territory is not only invaded; but their game is driven back, their murnong and other valuable roots eaten by the white man's sheep and other deprivations, abuses and miseries are daily increasing.

'Beyond the limits of European intrusion they dare not go', Tuckfield concluded, 'for fear of being murdered \& exterminated by hostile tribes'. ${ }^{30}$ Using the pseudonym Baxter to better acquire information from settlers opposed to the Protectorate, the chief protector had been told many settlers 'drive [Aborigines] off with horses men and cattle whips'. The increased Aboriginal violence this forced migration occasioned prompted him to label pastoralism 'a complete system of expulsion and extermination' in which, having ' $[t]$ heir lands sold from them and no provision made for their maintenance, and this by the govt. who are bound to protect them', Aboriginal peoples were 'driven on to hostile tribes who destroy them' ${ }^{31}$

Maria Moneypenny notes that within traditional Aboriginal societies, different age groups and both sexes held different relationships with one another, and this affected how strangers were received. She suggests that Aboriginal groups Australia-wide had ways of establishing the relationships of strangers to individuals within said groups, and thus to the group itself. 'Once the relationship was established', she writes, 'contact with the group could take

\footnotetext{
30 Tuckfield to WMS secs., 31 June 1840 [sic], MS-7667:Box-665, SLV

31 Robinson, journal, 3 May 1839, MS-9974, SLV
} 
place within the bounds of that relationship category.' 'No Aborigine', she further notes, 'could wander on to the land of another group without taking the necessary precautions to establish a relationship. Usually the host group would have been aware of the stranger's presence before any meeting took place and so would have had time to make appropriate preparations.'32

European invasion severely upset this way of life as it drastically and speedily increased inter-language group contact. Thus, as M.F. Christie notes, '[m]any Aborigines were killed in inter-tribal fighting occasioned by their forced exodus from their own country.'33 The problem was further exacerbated by Judge Willis' 'not guilty' ruling in R. $v$ Bolden (1841). Bolden, a Port Phillip pastoralist, had been charged with shooting an Aboriginal man named Tackiar. Willis, to the chief protector's great dismay, ruled that if a party receives a licence from Government to occupy a run, and any person white or black comes on my run for the purpose of stealing my property, I have a right to drive them off' ${ }^{34}$ The ramifications of this ruling were increased exodus and more violence.

For his efforts in the 'conciliation' of the Aboriginal peoples of Tasmania, George Augustus Robinson was rewarded with $£ 8000$, large land grants, and the task, at a salary of $£ 500$, of 'protecting' the Aboriginal peoples of Port

\footnotetext{
32 Maria Moneypenny, "Going out and coming in": Cooperation and Collaboration Between Aborigines and Europeans in Early Tasmania', Tasmanian Historical Studies, 5:1, 1995/1996, p.65; Blaskett, p.69

${ }^{33}$ Christie, p.42; cf. Keith Sinclair, The Origins of the Maori Wars [1957], second edition Auckland:1961, p.18

34 Port Phillip Gazette, 4 December 1841, p.2, SLV; Robinson, 'Annual Report', 1 January 1849, VPRS-2895P, unit-1, PROV, pp.23-24; Reynolds, This Whispering, p.52; Arkley, pp.217-218 \& 226-227; H.N. Nelson, 'The Missionaries and the Aborigines in the Port Phillip District', Historical Studies, 12:45, 1965, pp.65-66; Christie, pp.44-45
} 
Phillip as chief protector of Aborigines. ${ }^{35}$ To Robinson - whom '[a]ll historians of Australia should spend some time in the company of', yet 'about whom historians will forever argue' - were appointed assistant protectors William Thomas, Charles Wightman Sievwright, Edward Stone Parker, and James Dredge. ${ }^{36}$ Port Phillip was divided into four districts, and to each was assigned an assistant protector, with the chief protector based in Melbourne. ${ }^{37}$

The eldest of the assistant protectors, Thomas accepted the post at the age of forty-four. A Wesleyan Methodist and former schoolteacher, Thomas was allocated the Westernport or Melbourne district, which lay to the east of Melbourne and included the environs of the town and Gippsland. John Harris describes Thomas as ' $t$ t]he only Protector who might have fulfilled the spirit of the scheme', while C.E. Sayers felt that he was 'the best' of the protectors. ${ }^{38}$ When the Protectorate was terminated, Thomas was retained by Port Phillip Superintendent C.J. La Trobe as guardian of Aborigines.

\footnotetext{
35 Corris, pp.150-152; Reynolds, This Whispering, pp.47-49 \& 60; I.M. Crawford, 'William Thomas and the Port Phillip Protectorate, 1838-1849', MA thesis, University of Melbourne:1966, p.11; on Robinson in Van Diemen's Land see: G.A. Robinson, Friendly Mission: the Tasmanian Journals and Papers of George Augustus Robinson, 1829-1834, N.J.B. Plomley (ed.), Hobart:1966; Lyndall Ryan, The Aboriginal Tasmanians [1981], second edition Sydney:1996, passim; Ryan, Tasmanian Aborigines, passim; Vivienne Rae-Ellis, Black Robinson: Protector of Aborigines, Melbourne:1988, pp.9-145; Cassandra Pybus, Community of Thieves, Melbourne:1991, passim; Henry Reynolds, Fate of a Free People: a Radical Re-examination of the Tasmanian Wars, Melbourne:1995, passim; John Harris, One Blood: 200 Years of Aboriginal Encounter with Christianity: a Story of Hope [1990], second edition Sydney:1994, pp.95-99

${ }^{36}$ New South Wales Government Gazette, 12 December 1838, p.1085; Barta, p.526; Harris, p.95; Clark, iii:pp.103-134

37 Descriptions of the geographical bounds of these immense districts can be found in $H R V 2 B$, pp.451-452

38 Harris, p.158; C.E. Sayers, 'William Thomas', in Bride (ed.), Letters from Victorian Pioneers, p.397; Crawford, passim; Marie Hansen Fels, 'I Succeeded Once': the Aboriginal Protectorate on the Mornington Peninsula, 1839-1840, Canberra:2011, passim
} 
A former Wesleyan Methodist preacher, schoolteacher, and printer, Parker has also been described as 'the best' of the protectors. ${ }^{39}$ To Parker was assigned the Mount Macedon or north-western district, later known as the Loddon district, to the northwest of Melbourne. Like Thomas, Parker remained an assistant protector for the duration of the Protectorate.

Perhaps the least written-about of the initial protectors, Dredge was also of Wesleyan Methodist influence, and was also a former preacher and schoolteacher. As early as July 1818 Dredge had expressed a desire to 'quit my native shores and preach the Gospel to the heathen'. Twenty years later he was assigned the Aboriginal peoples of the Goulburn River district, to the northeast of Melbourne, to 'protect'. ${ }^{40}$ After just seven months living on the Goulburn - a period marked by a hostile relationship with his superior Robinson - in February 1840 Dredge tendered his resignation. The reasons for his resigning from the Protectorate are much debated, although Dredge himself later listed his motives as: a lack of specific instructions on what his position entailed; the lack of response to his official requests; the diminishing health of his wife; and that the Protectorate 'makes no provision for their spiritual instruction, therefore, it is not of Christ's appointment and cannot have his blessing $\cdot{ }^{41}$

After Dredge resigned he was replaced by William Le Souef. In mid-1843 Le Souef was dismissed for insubordination, the misuse of government prop-

${ }^{39}$ Nelson, 'Missionaries and the Aborigines', p.58n; H.N. Nelson' Parker, Edward Stone (18021865), $A D B$

40 quoted in R. Dredge, 'An awful silence reigns', p.18

41 Dredge to Harding, 12 September 1840, MS-5244, SLV, emphasis in original; Port Phillip Gazette, 16 December 1840, supplement, pp.1-2, SLV; Dredge, Brief Notices, pp.20-26 \& 36; R. Dredge, 'An awful silence reigns', pp.18-21; O'Connor, p.6; Rae-Ellis, pp.186-187; Cannon, Who Killed the Koories?, pp.9-10; Harris, p.158; Arkley, pp.104-107; Crawford, pp.235-236 
erty, and the harsh treatment of Aborigines in his charge. ${ }^{42}$ Following Le Souef's dismissal, Parker was required to ride between and supervise both his Mount Macedon district's Loddon River station and Le Souef's Goulburn River station. Parker was initially assisted at the former station by Robinson's recently bankrupted son-in-law Dr. James Allen. Allen, however, was soon dismissed, reportedly for thrice attempting to murder his wife. ${ }^{43}$

The odd man out, without an active religious background and not having been a schoolteacher, Sievwright has repeatedly been portrayed as unfit for the role of assistant protector, by both contemporaries and historians alike. Having served in the British Army for twenty years, Sievwright sold his commission to pay off gambling debts in 1837 . That same year he was accused of abandoning his wife and children to poverty in Malta - accusations of abandonment which would again arise when he left Australia, alone, in November 1845. Despite these blemishes, through his imperial connections Sievwright secured the post of assistant protector, daring even to request that of chief protector, having heard that Robinson had initially declined the position. ${ }^{44}$ To Sievwright, 'the most unpopular man that ever breathed' as one squatter termed him, was assigned the western district, which included the environs of Geelong and, at over 40,000 square kilometres, was an area more than half the size of his native Scotland. ${ }^{45}$

In addition to allegations of incompetence, or perhaps because of them, Sievwright was charged with moral transgressions. He was accused of at-

\footnotetext{
42 'Unregistered Correspondence Relating to the Dismissal of W. Le Souef', VPRS-4398, PROV; Christie, p.96; cf. Foxcroft, p.61

${ }^{43}$ Cannon, Who Killed the Koories?, pp.126-130; Rae-Ellis, pp.248-249

44 As Zoë Laidlaw shows, '[n]etworks of personal connections were of critical importance to colonial governance in the early nineteenth century'; Laidlaw, Colonial Connections, p.13; Sievwright to Glenelg, 23 February 1838, HRV2B, pp.380-381; Arkley, pp.55 \& 59-60

45 Niel Black, journal, 25 February 1840, cited in Mitchell, 'Flesh, Dreams and Spirit', p.75; Arkley, p.3
} 
tempting to seduce, or successfully seducing, his colleague Assistant Protector Parker's wife Mary on the voyage from Sydney to Melbourne, and of continuing this 'criminal intercourse' upon their arrival in Port Phillip. Sievwright was further accused of oppressive treatment and neglect of his own wife and children. Most scandalous of all, however, the assistant protector was alleged to have attempted incest with his eldest daughter, which Dredge asserted was attested to by Aborigines. ${ }^{46}$

Thomas informed Superintendent La Trobe that Aborigines scorned incest within their own society. He knew of one Aboriginal man 'who had a child by his daughter', and was thus 'looked upon as a regular beast' by other Aborigines, citing this as an example showing that Aboriginal peoples 'have some respect for the laws of nature; in fact, they are more delicate than white people in many respects'. ${ }^{47}$ Furthermore, Curr wrote of Aboriginal 'postmen', by whom 'the tribes kept themselves sufficiently well informed of what was occurring in their neighbourhoods', as 'the Blacks were, perhaps, more fond of gossip than any other people I have met with'. ${ }^{48}$ If Aborigines did suspect Sievwright of attempted incest the news would have quickly spread far and wide and affected relations with their protector.

Frequently free with his opinions, Judge John Walpole Willis described Melbourne as 'a miserable little town, where everyone knows everyone's affairs, and frequently states more than the truth respecting them'. ${ }^{49}$ Accusations and gossip spread like bushfire, and allegations of immorality certainly did affect Sievwright's relationships with other Europeans in the district whom,

\footnotetext{
46 Corris, pp.94-97; Cannon, Who Killed the Koories?, pp.25-28; Arkley, pp.14-15, 59-63, 326-333, 362-364, 377-378 \& 418; Clark, iii:p.132; Rae-Ellis, p.191; Critchett, pp.147-148

47 Thomas, 'Brief Account', p.437

48 E.M. Curr, Recollections of Squatting in Victoria, then called the Port Phillip District (from 1841 to 1851) [1883], Melbourne:1965, pp.132-133

${ }^{49}$ quoted in Vasey, p.42; on Willis see also: Davies, pp.313-335; Clark, iii:p.130
} 
it was reported, 'cut him upon all occasions, and will not suffer him to enter their houses', he being 'in very bad odour with the settlers'. ${ }^{50}$ In June 1842 'the hated protector' was suspended pending investigation into his alleged immorality, the neglect of his family, and the improper use of government stores. ${ }^{51}$ His suspension was never lifted, though it appears he was never formally dismissed either. ${ }^{52}$ Scandals concerning morality were relatively common among colonial officials during this period and, as is further explored in chapter five, affected the attempted 'civilisation' and Christianisation of Aboriginal peoples. Dr. John Watton replaced Sievwright at the Mount Rouse Station in June 1842.

The Port Phillip Protectorate was implemented with high aims. At the end of January 1838 Lord Glenelg sent Governor Gipps a copy of the Report of the Select Committee on Aborigines (British Settlements). Accompanying the report, Glenelg wrote to Gipps outlining 'points which will form the ground of Instructions which you will issue to' the protectors. The protectors were to: travel with Aboriginal groups 'until they can be induced to assume more settled habits of life'; 'watch over the rights and interests of the natives; protect them ... from any encroachment on their property and from acts of cruelty, oppression or injustice; and faithfully represent their wants, wishes or grievances'. Once they had been 'induced in any considerable numbers to locate themselves in a particular place', the protectors were to 'teach and encourage them to engage in the cultivation of their grounds, in building suitable habitations for themselves, and in whatever else may conduce to their civilization

\footnotetext{
${ }^{50}$ Sydney Herald, 6 April 1840, supplement, p.1

${ }^{51}$ Arkley, pp.340-347, 362-364, 376-378, 410-411 \& 418; Jessie Mitchell, “'The galling yoke of slavery": Race and Separation in Colonial Port Phillip', Journal of Australian Studies, 33:2, 2009, p. 130

52 Twomey, p.105n; Corris, pp.94-97 \& 95n; cf. Foxcroft, p.63
} 
and social improvement'. Gipps was further informed that the protectors were to promote 'the moral and religious improvement of the natives, by instructing them with elements of the Christian religion'. ${ }^{53}$

The aim of the protectorate was to protect, 'civilise', and Christianise the Aboriginal peoples of the Port Phillip District. During their first six months in the district, however, the assistant protectors were confined to Melbourne, regularly bemoaning their lack of specific instructions. This lack of specificity was something the protectors often complained of but was never effectively remedied - indeed this grievance greatly contributed to Dredge's resignation. It was also a feature which accompanied the Protectorate across the Tasman Sea to New Zealand.

From whom were the protectors to protect Aborigines? And how could Aborigines be protected from 'encroachment on their property' when this was the aim of the protectors' employer, the Crown, in the colonisation of the district? The protectors were further to protect Aborigines from 'cruelty', which included violence, at the hands of Europeans, but European settlement also greatly exacerbated traditional Aboriginal violence - were the protectors to prevent this too? These problems were compounded by the fact that Aborigines were British subjects, and had - in theory, though not in reality - the rights and protections which that status offered. As it transpired, one of the main tasks attempted by the protectors was the suppression of Aboriginal violence.

53 Glenelg to Gipps, 31 January 1838; see also: Grey to assistant protectors, 6 February 1838; assistant protectors to col. sec., 26 October 1838; col. sec. to assistant protectors, 11 December 1838; Robinson to col. sec., 12 March 1839; Robinson to assistant protectors, 21 March 1839; Thomas, journal, 4 May 1839 - HRV2B, pp.373-378, 385-386, 390-391, 444-445 \& 523; Robinson, 12 \& 21 March 1839, Clark (ed.), Journals ... Volume One, pp.14 \& 18; Dredge, diary, 20 March 1839, MS5244, SLV; Orton to WMS secs., 13 May 1839, HRV2A, p.120 
Frustrated by the lack of more specific instructions and unsure how best to proceed, and witness to increasing inter-language group violence, the protectors began to dedicate themselves to the suppression of Aboriginal violence soon after their January 1839 arrival in Port Phillip. To the protectors, internecine violence was a visible and yet remediable sign of 'savagery' - a traditional way of life they perceived to have victims whom they could 'protect'.

On 23 March 1839 Dredge reported 'a fight took place between the different tribes of blacks just outside of' Melbourne. Following the 'timely intervention of the Protectors', without which 'the consequences would have been far more serious', three Aboriginal men and their 'lubras' accompanied the protectors to their camp, where the Europeans washed and dressed their wounds and gave them a cup of that good-old British cure-all, tea. The following day, one of 'much fatigue and anxiety', Dredge noted: '[t]he commotion amongst the blacks yesterday rendered my presence among them necessary all day'. 'It is truly distressing', he continued, 'to see a number of fine fellows, together with the women and children, in such a state of destitute vagrancy - while strangers from a civilized country are fattening on their patrimonial soil'.$^{54}$

Dredge clearly identified a link between the European occupation of Aboriginal country and increased Aboriginal violence. As Aborigines were encouraged or driven from their country, many travelled to Melbourne, where they came into contact with enemy or unknown language groups. As the assistant protector noted elsewhere, the Aborigines 'have been treated unjustly; their country has been taken from them, and with it their means of subsistence - whilst no equivalent has been substituted'. He disputed the argument that 'those natives, on whose patrimony we have located ourselves, our

${ }^{54}$ Dredge, diary, 23-24 March 1839, MS-5244, SLV; see also: O'Connor, p.7 
flocks, and our herds, may find ample room and sustenance beyond us, and that they ought to be driven into the interior'. '[T]he whole land', he declared, 'as has been shown, is divided amongst them by ancient political and social usage, and the territory assigned to each tribe is its "home," within its limits the various families, for generations, have been supplied with roots, fish, or animals, constituting the humble and scanty fare which they have deemed sufficient for all purposes of their maintenance'. '[W]ere they to remove themselves, according to our dictation, within the limits occupied by other communities, such intrusion would inevitably bring down upon them the vengeance of the original occupants' ${ }^{\prime 55}$

Greatly exacerbated by the arrival of Europeans, Aboriginal violence was a significant factor in the massive Aboriginal population decline in Port Phillip. ${ }^{56}$ Robinson noted that the Aboriginal peoples he met on his 1841 'Expedition to the Aboriginal Tribes of the Western Interior' were 'now the mere remnants of a once powerfull race'. 'The decay is still going on', he wrote, 'and judging from the past, a brief period may suffice for their total extinction.' The chief protector believed that the rapid population decline was due to: 'disease and natural decay, unnatural causes, attacks from hostile tribes, and Europeans assassination'. Extrapolating upon the impact of interlanguage group violence, he noted that ' $[w]$ hole sections have been annihilated by contending tribes'. Later during the expedition he encountered a group whom he believed to be 'nearly extinct'. He asked where their country was. By way of reply they 'beat the ground and vociferated, Deen! deen! (here! here!), and then, in a dejected tone, bewailed the loss of their country'.

\footnotetext{
55 Dredge, Brief Notices, p.14, emphasis in original

56 Nance, pp.538-540; Diane E. Barwick, 'Changes in the Aboriginal Population of Victoria, 18631966', in D.J. Mulvaney and J. Golson (eds.), Aboriginal Man and Environment in Australia, Canberra:1971, p.288; Barta, p.536
} 
Robinson mused that '[d]isease and natural decay, feuds, snakes, and white men have reduced their numbers. ${ }^{57}$

Robinson's assertion that snakes were significantly responsible for the immense population decline faced by Aboriginal peoples overlooked a coexistence of some 60,000 years between Aborigines and other reptiles prior to invasion. Death from snakebite, like other deaths, was believed by Aborigines to be the workings of sorcery and thus compounded Aboriginal violence; however this of course was not a new factor in Aboriginal society. ${ }^{58}$ The chief protector's focus on 'natural decay', the idea of an already dying race, as well as placing the blame on snakes, is an early manifestation of the anodyne explanation for the expected extinction of Aboriginal peoples which absolved Europeans of guilt - an argument recently revived by Keith Windschuttle..$^{59}$

Detailing an early attempt to punish Aboriginal violence, in April 1840 Assistant Protector Parker reported to the chief protector that he had investigated the alleged murder of a Taungurong woman by a member of the Woiworung. He wrote that while he had obtained 'circumstantial evidence', there were 'no further steps taken from the want of police' assistance. In the same report, Parker informed Robinson of 'the rapid occupation of the entire country by settlers, and the consequent attempts made to deprive the aborigines

\footnotetext{
57 Robinson, 30 March \& 20 June 1841, Clark (ed.), 'In Quest of the Tribes', pp.104 \& 110; Robinson 2 April \& 20 June 1841, Kenyon (ed.), 'Report of an Expedition', pp.144 \& 152

58 Morgan, p.77; Isabel Ellender and Peter Christiansen, People of the Merri Merri: the Wurundjeri in Colonial Days, Melbourne:2001, p.66

59 Windschuttle, Fabrication of Aboriginal History, Volume One, passim; Keith Windschuttle, The Fabrication of Aboriginal History Volume Three: the Stolen Generations, 1881-2008, Sydney:2009, passim; Keith Windschuttle, 'The Myths of Frontier Massacres in Australia', 3 parts, Quadrant, 44:1012,2000, pp.8-20, 17-23 \& 6-20
} 
of the natural products of the country, and even to exclude them from their native soil'. He observed: ' $[t]$ he very spots most valuable to the Aborigines for their productiveness - the creeks, water courses, and rivers - are the first to be occupied.'

He also quoted, perhaps a touch acrimoniously, from his instructions:

[a]ppointed as I have been by Her Majesty's Government specially "to watch over the rights and interests of the natives", and to "protect them from any encroachments on their property, and from acts of cruelty, oppression or injustice", I deem it my duty respectfully but firmly to assert the right of the Aborigines to the soil and its indigenous productions, until suitable compensation be made for its occupation by reserving and cultivating a sufficient portion for their maintenance.

He complained, however, that owing to 'the desultory nature of my present official duties', he found it 'next to impossible' to employ 'the only efficient means of permanent civilization', Christian instruction. Meanwhile, he concluded, 'the wandering Aborigines are sinking to a lower degree of moral degradation by the pernicious intercourse which they have with the vitiated portion of the lower classes in the colony' ${ }^{60}$

On 23 September the previous year, Thomas had lamented that an Aboriginal man had speared his 'lubra' for inconstancy. 'These cases should be punished', the assistant protector wrote, 'but what can be done with them?' 'Under present circumstances there appears no plan or system in the Protectorate', he added. 'Would to God some plan were adopted. If bad, might work itself good, but no plan at all is awful. ${ }^{61}$ The lack of specific instructions as to how they were to protect Aborigines, or indeed what 'protection'

\footnotetext{
60 Parker to Robinson, 1 April 1840, HRV2B, pp.691-696

61 Thomas, journal, 23 September 1839, HRV2B, p.546
} 
actually entailed, greatly frustrated the assistant protectors. Moreover, although Aborigines were technically British subjects, subject to British law, an inability by colonial administrators to enforce this, and contradictory Aboriginal-specific laws such as that preventing them giving evidence in court, further impeded the protectors' efforts.

Missionaries were similarly frustrated in their attempts to suppress Aboriginal violence. Tuckfield wrote to fellow Wesleyan Methodist missionary the Reverend Benjamin Hurst in January 1840: '[i]t seems to me, to be of great importance to us in our work, that we clearly assertain, wither the blacks are, or not, in their assaults on each other amenable to our laws; and if so what measures are to be taken to bring them to justice' ${ }^{62}$

In October 1839 Thomas asked Robinson how police assistance might be obtained when he needed it, having already been thrice denied such aid. He complained bitterly to the chief protector: 'I see daily encroachments made upon the people of my charge. I can almost say with the Apostle Paul, it is not against flesh and blood, but against principalities, powers, \&c., that I have to contend with.' 'And now what can I do?', he asked.

I find one of my charges, his head a complete gore of blood; he points out the villain, he is seized and dragged to jail, but suffered to escape because an Aborigine cannot give evidence ... There appears a mystical cloud of hapless bodings hanging over the Aborigines of this land, and as I am not allowed by the obstacles thrown in my way to encircle them in the arms of protection, will do my utmost to encircle them within the pale of civilization, praying in faith believing that God ... will bring things to pass. ${ }^{63}$

\footnotetext{
62 Tuckfield to Hurst, 17 January 1840, MS-7667:Box-665, SLV

63 Thomas to Robinson, 19 October 1839, HRV2B, p.595
} 
The following month Thomas witnessed more Aboriginal violence. He noted '[d]eath, methought, must now be the end'. The assistant protector excused himself from blame however, complaining 'the Police Magistrate is determined not to interfere'. 'What unconstitutional notions the Magistrates of New South Wales must have', he added. 'Are not the blacks and whites Her Majesty's subjects?' ${ }^{64}$

Finding their efforts to suppress Aboriginal violence using British law frustrated by the inability or unwillingness of other colonial officials to enforce British law on Aborigines, protectors and missionaries attempted this through the 'civilisation' and Christianisation of Aborigines, an objective also promoted by the parliamentary select committee which had brought the Protectorate into being. ${ }^{65}$ Thus the protectors sought to suppress Aboriginal violence outside the court system, through the very end to their means. The protectors held that in order for Aborigines to become 'civilised' and Christianised, Aboriginal violence must be ended, which, they believed, could be brought about by 'civilising' and Christianising Aborigines.

The early New South Wales governors were instructed to punish 'any of our subjects' who injured Aborigines in the colony. ${ }^{66}$ As the Aboriginal peoples of the colony were themselves, in theory, British subjects, this could logically

\footnotetext{
64 Thomas, journal, 28 November 1839, HRV2B, pp.568-570 \& 570n

65 Tellingly, the committee's full title was: 'the Select Committee to consider what measures ought to be adopted with regard to the Native Inhabitants of Countries where British Settlements are made, and to the neighbouring Tribes, in order to secure them the due observance of Justice and the protection of their Rights; to promote the spread of Civilization among them, and to lead them to the peaceful and voluntary reception of the Christian Religion'; Elbourne, 'Sin of the Settler', np

${ }^{66}$ R. Cranston, 'The Aborigines and the Law: an Overview', University of Queensland Law Journal, 8, 1973-1974, p.61; Barry Bridges, 'The Aborigines and the Law: New South Wales 1788-1855', Teaching History, 4:3, 1970, pp.40-42
} 
be interpreted to include the prevention of internecine Aboriginal violence. Indeed, in May 1816 Governor Macquarie proclaimed a ban on Aborigines carrying traditional weapons. Those Aborigines who enforced traditional law within or near Sydney and other European settlements would be themselves punished, as their actions were 'repugnant to the British Laws, and strongly militating against the Civilization of the Natives, which is an Object of the highest Importance to effect, if possible'. ${ }^{67}$

In 1829, when an Aboriginal man identified as Dirty Dick was killed in Sydney, Bob Barrett (or Ballard), also Aboriginal, was imprisoned for his murder. This was among the first tangible attempts to apply British law in punishing internecine Aboriginal violence in New South Wales. ${ }^{68}$ After Barrett had been 'for some time confined to gaol', however, it was decided that he could not be tried under British law. The chief justice observed: '[i]n occupying a foreign country, the laws that are imported have reference only to the subjects of the parent state'. He asserted that Aborigines 'have no magistrate to resort to, and therefore act upon the original principal of self redress', and, he believed, 'the greatest injustice would arise, if that brute force to which they have recourse were to be restrained by the laws by which civilized society is bound'. 'For those reasons', the chief justice concluded, 'I do not think it just to apply our laws in cases arising solely between the natives themselves'. Justice Downing agreed. 'The savage ... is equally entitled to protection from British law, if by circumstances that law can be administered between Britons \& the savage'. 'We have a right to subject them to our laws if they injure us', he continued, 'but I know of no right possessed by us, of in-

\footnotetext{
67 Proclamation, enclosed in Macquarie to Bathurst, 8 June 1816, Frederick Watson (ed.), Historical Records of Australia, series I, 26 vols., Sydney:1914-1925, ix:pp.139-145

68 On the earlier example of Musquito see: Ryan, Tasmanian Aborigines, pp.45-47 \& 64
} 
terfering where their disputes or acts, are confined to themselves, and affect them only.' Barrett was therefore discharged. ${ }^{69}$

Nevertheless, on 11 April 1836 the New South Wales Supreme Court tried Aboriginal man Jack Congo Murrell for the murder of another Aboriginal, Bill Jabingi (or Jabenguy), on the Windsor Road west of Sydney. Murrell's defence counsel, Sydney Stephen, argued that because New South Wales had not been 'settled' by Europeans, as it was already populated (thus rejecting terra nullius), ${ }^{70}$ nor had it been 'conquered', as war was not declared, Aboriginal law should not be usurped by British law in internecine matters. The three judges on the case unanimously rejected this defence. Their ruling signalled that Aborigines were British subjects who were subject to British law, both in inter-racial and internecine 'crimes'. Justice Burton asserted that 'the greatest possible inconvenience and scandal to this community would be consequent' if Murrell's defence was upheld, meaning that 'crimes of murder and others of almost equal enormity may be committed by those people in our Streets without restraint ${ }^{\prime}{ }^{71}$

Five years later, however, in the Port Phillip District in 1841, Judge Willis ignored the precedent established in R. v Jack Congo Murrell. Willis ruled that Wadora man Bonjon, who was being tried for killing Gulidjan man Yammowing, could not be tried for murder under British law as the judge

\footnotetext{
69 Sydney Gazette and New South Wales Advertiser, 19 February 1829, p.2, 29 February 1829, p.2, 23 April 1829, p.2, and 16 June 1829, p.3; Downing cited in Bruce Kercher, 'R v Ballard, R v Murrell and R v Bonjon', Australian Indigenous Law Reporter, 3:3, 1998, np; see also: Australian, 20 February 1829, p.3, 24 February 1829, p.3, and 16 June 1829, p.3; Barry Bridges, 'The Extension of English Law to the Aborigines for Offences Committed Inter Se, 1829-1842', JRAHS, 59:4, 1973, p.264

70 Alan Frost, 'New South Wales as Terra Nullius: the British Denial of Aboriginal Land Rights', Historical Studies, 19:77, 1981, pp.513-523

${ }^{71}$ Burton cited in Kercher, np; see also: Sydney Gazette and New South Wales Advertiser, 23 February 1836, p.3, 2 April 1836, p.2, 12 April 1836, p.3, 5 May 1836, p.2, 14 May 1836, p.3; Sydney Herald, 8 February 1836, p.3, 18 April 1836, p.3; 5 May 1836, p.2, and 16 May 1836, p.3; Colonist [Sydney], 12 May 1826, p.6; Davies, pp.325-326; Cranston, pp.62-63; Elbourne, 'Sin of the Settler', $\mathrm{np}$; Bridges, 'Aborigines and the Law', p.46
} 
doubted his authority over internecine Aboriginal 'crimes'. Echoing Stephen's defence of Murrell, Redmond Barry argued that as the Aboriginal peoples of Port Phillip had neither been conquered nor had they willingly relinquished their land, they therefore retained their sovereignty. As such, Barry declared, Aboriginal peoples should be treated as 'self-governing communities' ${ }^{72}$ Justice Willis agreed, and referred to the Report from the Select Committee on Aborigines (British Settlements) in doing so. ${ }^{73}$ Bonjon was eventually discharged because he was ruled to be incapable of pleading: the jury decided that although he was able to state whether he had or had not killed Yammowing, he was unable to understand the European concept of murder. ${ }^{74}$ Both Robinson and Sievwright were dismayed at the decision. The assistant protector wrote to his superior noting that '[i]nterference in these barbarous habits becomes imperative', for internecine violence 'must materially interfere with every attempt to establish a well disciplined institution' ${ }^{75}$ Sievwright felt that if Aborigines could not be protected from internecine violence by British law, the protectors' task of 'civilising' and Christianising them, which required the suppression of violence, was made much more difficult.

In addition to concerns surrounding their legal status, problems with translation and Aborigines seeking to take advantage of colonisation to revenge traditional animosities further complicated legal attempts to suppress Abo-

\footnotetext{
72 Port Phillip Patriot and Melbourne Advertiser, 20 September 1841, pp.1-3, SLV

73 Willis cited in Kercher, np; Laidlaw, 'Integrating Metropolitan, Colonial and Imperial Histories', pp.77-78 \& 78n

74 Robinson, journal, 14 August 1841, MS-9974, SLV; Gipps to Russell, 24 January 1842, Aborigines (Australian Colonies): Return to an Address of the House of Commons, Dated 5 August 1844 for, Copies or Extracts from the Despatches of the Governors of the Australian Colonies, with Reports of the Protectors of Aborigines, and any other Correspondence to Illustrate the Condition of the Aboriginal Population, London:1844, pp.143-144, SLV; Willis to Gipps, 22 September 1841, Aborigines (Australian Colonies), pp.146-155, SLV; Christie, pp.112-113; Corris, pp.57-59; Arkley, pp.290-293; Bridges, 'Extension of English Law', pp.266-268; Kercher, np; Davies, pp.325-332; Cannon, Who Killed the Koories?, pp.77-80; Vasey, pp.47-49

75 Sievwright to Robinson, 24 January 1842, cited in Davies, p.329
} 
riginal violence. As William Buckley observed in noting the numerous languages spoken in Port Phillip, '[h]ow careful then ought those persons to be, who are known as what are called Protectors of Aborigines, when they attempt to interpret on trials in Courts of Justice'. He claimed that 'the vindictive character of the natives ... leads them, in many instances, to give evidence founded upon revenge and falsehood'. ${ }^{76}$ Aborigines were willing to utilise Europeans in adapting their means of resolving traditional animosity.

Having recently read the Report from the Select Committee on Aborigines (British Settlements), in 1837 Lord Glenelg wrote to Governor Gipps reiterating that the Aborigines 'must be considered as Subjects of the Queen, and as within H.M.'s Allegiance'. ${ }^{77}$ In the eyes of the Crown, Aborigines had the same rights as British citizens and were to be treated as such. While this premise had been invoked in the 1836 trial of Jack Congo Murrell, and would be reaffirmed by the 1838 Myall Creek retrial, colonists did not generally accept that Aborigines had the rights and protections of British subjecthood. ${ }^{78}$ Two years after Glenelg's reminder, Gipps published a notice in the New South Wales Government Gazette declaring that Aborigines were equal in the eyes of the law, and as such, when any were killed, an inquiry would be held, with 'no distinction in such cases, whether the aggressors or parties injured be of one or the other race or colour' ${ }^{79}$

On 18 September 1839, while in Melbourne, Thomas enquired of a group of Aborigines why they had killed an Aboriginal man whom he identified as Peter: '[w]hat for my black fellows kill em good poor black fellow?' In re-

76 Morgan, pp.101-102; see also: Bridges, 'Aborigines and the Law', pp.59-61

77 Glenelg to Bourke, 26 July 1837, Historical Records of Australia, series I, xix:pp.47-50

78 R.H.W. Reece, Aborigines and Colonists: Aborigines and Colonial Society in New South Wales in the 1830s and 1840s, Sydney:1974, pp.118-119; Christie, p.109; Alan Lester, 'Colonial Settlers and the Metropole: Racial Discourse in the Early 19th-Century Cape Colony, Australia and New Zealand', Landscape Research, 27:1, 2002, p.43; Lester and Dussart, 'Trajectories of Protection', p.216

79 New South Wales Government Gazette, 22 May 1839, p.606 
sponse, one man exclaimed '[n]o good that black fellow, no his country this, and no good you', and tried to hit the assistant protector on the head with his tomahawk. Thomas managed to deflect the blow with his wrist; however, this fright, and one the previous day when he had been choked by an Aboriginal man while out walking alone, led him to conclude: 'I should in the end fall by these people'. Three days later when Thomas again asked why they had killed Peter, the response was: '[w]hite man very angry, white man no let white man kill white man; nor black man, black man'. Thomas informed the group that 'white man was only sulky with those that killed Peter'. He noted in his journal that as a result of Europeans' reactions to the killing, Aborigines 'scarce venture into Melbourne'. 'May this excitement at all events check this awful practice', he hoped. ${ }^{80}$

The chief protector was clearly concerned about Aboriginal violence and saw preventing it as within the role of the Protectorate. Three days prior to Thomas' enquiries into the death of Peter, Robinson, having heard of the killing, had written to Thomas scolding him for not protecting Aborigines from internecine killings. 'To my knowledge not less than from 20 to 30 human beings among the aboriginal natives have been murdered within these few weeks past', the chief protector wrote, 'and it shall be remembered that the Aborigines in the interior are as much under my protection as those in the environs of the township, therefore the latter cannot be permitted with impunity to maraud and murder in cold blood unoffending women and children. ${ }^{81}$

Thomas replied that although he was 'well aware of the difficulty of bringing aboriginal offenders to justice on aboriginal evidence, on account of their ig-

\footnotetext{
80 Thomas, journal, 17-21 September 1839, HRV2B, pp.544-545

81 Robinson to Thomas, 15 September 1839, HRV2B, pp.585-586; Robinson, journal, 15-18 September 1839, MS-9974:CY-424, SLV
} 
norance of the obligation of an oath', he was 'anxious to bring the murderers if possible to condign judgement'. He had consulted the crown solicitor, who had informed him that 'in no case whatever can the deposition of an Aborigine be taken unless so far civilized as to understand the nature of an oath as by law established, and brought to a sense and knowledge of a $\mathrm{Su}$ preme Being, not even in common assault' ${ }^{82}$

Later that month, in relation to the death of an Aboriginal man named Tommy, Thomas wrote to John Hubert Plunkett, attorney-general and crown law officer who had overseen the verdict which resulted in seven European men being executed for the murder of Aborigines at Myall Creek in 1838, to inquire 'may there not be some cases that may warrant the detaining of the supposed guilty party in order to avoid other outrages' - even though, as he knew, they could not be brought to 'justice' using Aboriginal evidence? ${ }^{83}$

Among objections to the assertion that Aborigines had the same rights as British citizens was the concern that they would be able to sit on juries as well as give evidence as witnesses in court. Barrister Robert Lowe, Viscount Sherbrooke, asserted that he would 'rather place his naked foot on the burning ploughshares' to prove his innocence than to submit himself to the evidence 'of savage and blood-thirsty cannibals'. William Charles Wentworth, a rival of Lowe's eulogised as the 'father of Australian democracy', declared

\footnotetext{
82 Thomas to Robinson, 23 September 1839, HRV2B, pp.587-588; on October 1839 the New South Wales Legislative Council, at the desire of the attorney-general, passed an Act to 'allow the Aboriginal Natives of New South Wales, to be received as competent Witnesses in Criminal Cases'. The following week Gipps informed Normanby of the Act, noting it contained the stipulation that it would not come into effect until the approval of the Queen was given, which Gipps was seeking in writing to Normanby. Russell wrote to Gipps in August 1840 informing him that Her Majesty had disallowed the Act; Gipps to Normanby, 14 October 1839; Russell to Gipps, 11 August 1840 - Aborigines (Australian Colonies), pp.26-27, SLV

83 Thomas to Plunkett, 30 September 1839, HRV2B, p.589; T.L. Suttor, 'Plunkett, John Hubert (1802-1869), ADB
} 
'[i]t would be quite as defencible to receive as evidence in a Court of Justice the chatterings of the orang-outang as of this savage race' ${ }^{\prime}{ }^{84}$

To sit on a jury in New South Wales during the early colonial period a person had to be male, aged twenty-one to sixty, and have a minimum income of $£ 30$ per annum from personal property - thus effectively excluding Aborigines. Aborigines, furthermore, could not be called as witnesses because by law witnesses had to have knowledge of a Supreme Being in order to swear testimony. 'The testimony of Blacks being it is said no evidence at all', lamented the chief protector. ${ }^{85}$ Moreover, as defendants, Aborigines and Europeans alike could not give evidence in their own defence. ${ }^{86}$ As Judge Willis observed, ' $[w]$ ithout a jury of your own countrymen, without the power of making adequate defence, or speech, or witnesses, you are to stand the pressure of everything that can be alleged against you, and your only chance of escape is, not the strength of your own, but the weakness of your adversary's case' ${ }^{87}$

As well as suppressing inter-language group violence, colonial officials also sought to restrain intra-language group violence. Although Thomas, having witnessed three instances of intra-language group judicial proceedings in Melbourne, acknowledged that these showed 'that the Aborigines have a law among themselves and know how to execute it', he was determined to quell such violence. ${ }^{88}$ Traditional Aboriginal means of conflict resolution were, however, often perceived by Europeans to be unregulated, and unacceptable,

\footnotetext{
${ }^{84}$ Sydney Morning Herald, 21 June 1844, p.2; Christie, pp.116-117; Bridges, 'Aborigines and the Law', pp.65-70; Ryan, Tasmanian Aborigines, p.77

85 Robinson, 2 June 1841, Clark (ed.), 'In Quest of the Tribes', p.109

86 Davies, pp.316n \& 317

87 cited in Vasey, p.48; Cranston, pp.64-65

88 Thomas, 'Report for 1 December 1843 to 1 March 1844', cited in Christie, p.13; see also: Thomas, 'Brief Account', pp.401-402; Cannon, Who Killed the Koories?, pp.132-134; Clark and Heydon, pp.21-25
} 
violence, although this was sometimes relatively minor. ${ }^{89}$ As medical officer W.H. Baylie observed of intra-language group judicial proceedings in 1843: 'many are the bruises and wounds given and received ere the fray terminates'. ${ }^{90}$

Just as Europeans were critiquing and attempting to suppress traditional Aboriginal means of justice, Aborigines were also questioning European law. As Christie notes, '[i]t was difficult for the Aborigines to appreciate the blessings and refinements of British civilization when they saw its most brutal aspects.' As many of the Europeans whom Aborigines encountered were assigned convicts or ex-convicts, they witnessed the vicious floggings dispensed in the name of British justice, or at least saw the mental and physical consequences of these. When a convict assigned to Thomas was given fifty lashes for 'quarrelling, fighting, swearing, \&c., other riotous conduct', the assignee showed his fresh wounds to the Aborigines camped with the assistant protector. The Aborigines were, Thomas observed, 'thunderstruck'. He questioned: '[w]hat impression may or may not this have upon their minds detrimental to falling in with civilization?' ${ }^{91}$ When the tools of 'civilised', Christian justice, the lash and the noose, met their counterparts, the spear and the waddy, mutual incomprehension reigned.

While Aborigines were, in theory, British subjects subject to British law, the realities of colonial life differed markedly from the ideals of the British gov-

\footnotetext{
89 Broome, Aboriginal Victorians, pp.28-29

90 W.H. Baylie, 'Remarks and Observations on the Habits and Customs of the Aborigines of the Western Port District, in the Province of Australia Felix', Port Phillip Magazine, 1:1, 1843, p.40

${ }^{91}$ Christie, p.127; Thomas, journal, 27 April 1839, HRV2B, p.521; see also: Jean Woolmington, "'Writing on the Sand": the First Missions to Aborigines in Eastern Australia', in Tony Swain and Deborah Bird Rose (eds.), Aboriginal Australians and Christian Missions: Ethnographic and Historical Studies, Adelaide:1988, pp.87-88; Broome, Aboriginal Victorians, p.5
} 
ernment. Philanthropists, both government and missionary, public and private, sought to suppress Aboriginal violence in their overarching aim of 'civilisation' and Christianisation, attempting to utilise the problematic status of British subjecthood in doing so. The very presence of Europeans, deemed necessary to 'raise' Aborigines to 'civilised' Christendom, was however, greatly exacerbating Aboriginal violence. Moreover, despite their intention to suppress Aboriginal violence, the protectors and other evangelicals contributed to the intensification of Aboriginal violence brought about by European invasion.

Aboriginal companions not only provided detailed topographical information, they also supplied knowledge about the languages and customs of the language groups with whom they held relations. ${ }^{92}$ However, as Robinson's experience attests to, when Europeans coaxed or forced their guides outside their geographical area of comfort, their Aboriginal companions became extremely nervous - sometimes with good reason.

During his 1841 expedition Robinson noted that his 'Native companions had a dread of the Boloke [Bolac] people, and it was with great difficulty I persuaded them to accompany me'. Robinson and his party camped on the edge of Lake Bolac, and the chief protector was told by his Aboriginal guides, a Gulidjan man and two 'Jarcoorts', that they expected to be killed in the night. 'They said the Boloke Natives were extremely insidious in their attack, and that before we could offer resistance we should be killed'. Robinson 'endeavoured to dispel their fears, but to no purpose'. Upon waking unharmed the following morning 'they took courage'. When fresh footprints were discovered about the camp however, Robinson's Aboriginal companions were quick to point out that their fears had not been wholly un-

92 Reynolds, 'The Land, the Explorers and the Aborigines', pp.217-218 
founded. ${ }^{93}$ In 1843 Assistant Protector Parker was told of the peoples of Lake Bolac by a Djadjawurung informant: "“Mainmait talle, mainmait murri-pargar, mainmait nalderrun; yurrong," that is, "they are foreign in speech, they are foreign in countenance, they are foreign altogether - they are no good!"' 94

Again on his 1841 expedition Robinson, on horseback, 'was anxious to hasten my journey and desired my Native attendants who were on foot to follow'. Upon reaching his resting place for the night, the chief protector was surprised to find his companions not far behind: 'they said they had run the whole distance from fear of the "Mane-mates" who were enemies to their tribe' ${ }^{95}$ Later on the same journey one of his companions, Eurodep, 'chief of the Jarcoorts', was killed by a man from another language group, the 'Wanedeets'. Robinson believed settlers to have instigated the interlanguage group killing, and regretted he 'had no legal power to punish' the instigators. To demonstrate his displeasure at the violence, however, he ordered 'the presents and supplies brought for their use to be taken away and given to other Blacks more deserving'.${ }^{96}$

Amid their somewhat vague instructions, the assistant protectors were told they were to establish stations, upon which they were to induce the numerous language groups in their respective districts to settle. While Thomas felt that 'there is not a more peaceable community than the blacks when but one tribe is present', encouraging numerous language groups to settle together

\footnotetext{
93 Compounding the multifarious situation, a confused Robinson believed an Aboriginal word, 'mainmeet', foreign or enemy peoples, to be the name of a language group; Robinson, journal, 30 March 1841, MS-9974:CY-432, SLV; see also: Mackaness (ed.), 'George Augustus Robinson's Journey', p.326

94 E.S. Parker, The Aborigines of Australia, Melbourne, 1854, SLV

95 Robinson, 30 March 1841, Clark (ed.), 'In Quest of the Tribes', p.103; cf. Robinson, 31 March 1841, Kenyon (ed.), 'Report of an Expedition', p.140

96 Robinson, journal, 27 June 1841, MS-9974:CY-441, SLV; Robinson, 25-28 June 1841, Clark (ed.), 'In Quest of the Tribes', p.111; Robinson, 25 June 1841, Kenyon (ed.), 'Report of an Expedition', p.154
} 
greatly exacerbated Aboriginal violence, causing both the protectors and missionaries great strife. ${ }^{97}$

In September 1839 Sievwright suggested to Robinson that different language groups should have their own reserves in their own country. The assistant protector questioned the practicability of uniting tribes for the purposes of civilizing them'. He felt that 'to induce other tribes of strange habits, customs, and speaking a totally different language, to unite them with those whom they have hitherto been hostile ... would render abortive any attempt to civilize or improve the Aborigines or uphold a well-regulated Establishment'. ${ }^{98}$ In seeking to 'civilise' and Christianise Aboriginal peoples, in no small part to suppress Aboriginal violence, the protectors sought to induce them to settle together on stations, regardless of traditional hostilities. This had the effect of escalating, rather than suppressing Aboriginal violence and was a problem faced by other philanthropists, notably missionaries, both in Port Phillip and wider-Australia. Philanthropists thus further aggravated the very problem they sought to resolve.

Having spent three winter weeks in 1838 searching for a suitable location for his mission station, Tuckfield ultimately selected a site on the Barwon River. The chosen site had good water, agricultural land, and timber for firewood and building. As significant was that it was 'also central for at least three tribes' ${ }^{99}$ Tuckfield's superior Orton happily repeated this to the WMS secretaries in London, emphasising that the site was at 'the junction of the Barrabool [Wathaurong] and the Lake tribes'. ${ }^{100}$ The mission station, located

\footnotetext{
97 Thomas, 'Brief Account', p.434

98 Sievwright to Robinson, 27 September 1839, HRV2B, p.654; on Sievwright's attempt to establish stations at Keilambete and Terang see: Arkley, pp.130-143, 160-161 \& 413-414; Corris, pp.93-94

99 Tuckfield to WMS secs., 12 August 1838, HRV2A, p.106

100 Orton to WMS secs., 27 September 1838, HRV2A, p.109
} 
where Wathaurong country, Gulidjan country, and Djargurdwurung country intersected, was named Bunting Dale and operated from 1838 to $1843 .{ }^{101}$

Highlighting the problems experienced in encouraging antagonistic language groups to settle together at Bunting Dale, before long Tuckfield reported that the Wathaurong were afraid to come on the station in consequence of having killed a female member of the Gulidjan. The missionary noted that he had reported this incident to Sievwright, the western district assistant protector, but complained 'nothing had been done as yet to bring them to justice'. Tuckfield protested that Sievwright 'pretends to punish the lesser crimes, but when spoken to respecting capital crimes he appears to know not what to do'. Two days later Tuckfield wrote of violence arising from a dispute between the Wathaurong, Gulidjan, and Djargurdwurung over women. This culminated in the worst 'skirmish' the missionary had seen: 'I was really afraid they would kill each other'. The result of these inter-language group disputes was that Tuckfield forced, using the withdrawal of rations, the Wathaurong and the Djargurdwurung to leave the station, temporarily allowing only the Gulidjan to remain. Early the following year Tuckfield lamented with frustration: ' $\mathrm{O}$ when will the period arrive when these shall [not] learn war any more! May God hasten the happy period!'102

Later the same month Tuckfield again regretted inter-language group violence at Bunting Dale. 'During the short time I have been on the Station', he exclaimed to his superiors in London, 'the curiosity of the surrounding tribes has been excited.' Tuckfield celebrated that 'detachments of four tribes have been with us at the same time', but bewailed the fact that '[t]hese have been

\footnotetext{
${ }^{101}$ Ritchie, 'sound of the bell amidst the wilds', pp.98-126; Sam Ritchie, “"No White man on the Station but myself": Whiteness as a Category of Analysis for the Reverend Francis Tuckfield', ACRAWSA e-journal, 5:1, 2009, pp.1-10

${ }^{102}$ Tuckfield, journal, 14-18 December 1839 \& 10 January 1840, MS-7667:Box-655, SLV
} 
seasons of great anxiety to us, for it was with the utmost difficulty we could keep them from going to war with each other'. 'By night and by day', he continued, 'I have been obliged to get among them to use my influence in appeasing their fury', in which, he felt, he had succeeded 'to a certain extent'. ${ }^{103}$ Upon arriving at Bunting Dale on 20 March 1841, Robinson reported that the 'existing feuds' of the language groups upon whose bordering country the mission sat, 'prevent sociality, and are the occasion of deadly strife'. The chief protector added that two Aborigines had been killed 'a short time previous' to his arrival. ${ }^{104}$ Reports of inter-language group violence permeate Tuckfield's writings and this fighting is often cited as a primary cause of the 'failure' of the Wesleyan Methodist mission station. ${ }^{105}$

Briefly preceding Bunting Dale was a government mission on the outskirts of Melbourne, established in 1837. ${ }^{106}$ In order to 'civilise' and Christianise the Aboriginal peoples of the area immediately surrounding Melbourne, the missionary George Langhorne was instructed to assemble 'the blacks on one or more villages'. Replying to this instruction, the missionary suggested to Governor Bourke that 'the members of [the village] should all be of the same

\footnotetext{
103 Tuckfield to WMS secs., 29 January 1840, HRV2A, p.146

104 Robinson identified these groups as the 'Colijans' (Gulidjan), the 'Jarcoorts' (Djargurdwurung), and the 'Wodowros' (Wathaurong); Robinson, 20 March 1841, Clark (ed.), 'In Quest of the Tribes', p.101

105 Tuckfield, 'Report of the Wesleyan Missionary Society's Mission to the Aborigines of the SubDistrict of Geelong, Port Phillip, for the year ending December 1842', nd, enclosed in Gipps to Stanley, 3 April 1843, Aborigines (Australian Colonies), pp.257-259, SLV; Corris, pp.74-78; Foxcroft, pp.79-86; Blacket, Missionary Triumphs, pp.164-167; G.W. Greenwood, 'Reverend Francis Tuckfield's Magnificent Failure at Bunting Dale', Heritage, 6, 1956, pp.3-21; Heather Le Griffon, Campfires at the Cross: an Account of the Bunting Dale Aboriginal Mission at Birregurra, near Colac, Victoria 18391851, Melbourne:2006, passim; John Ferry, 'The Failure of the New South Wales Missions to the Aborigines before $1845^{\prime}, A H, 3,1979$, p.30

106 Preceding even this attempt to suppress Aboriginal violence in Port Phillip, William Buckley, who although 'careful not to introduce' Christianity, reported that he had 'often prevented bloodshed by acting as mediator' and claimed to have 'acquired great influence in settling their disputes', preventing '[n]umbers of murderous fights'. Following Buckley, the Port Phillip Association briefly appointed Dr. A. Thompson to minister to the Aboriginal peoples of the district; Morgan, p.101; 'George Langhorne's Reminiscences of William Buckley', in John Morgan, The Life and Adventures of William Buckley [1852], Firle, Sussex:1979, p.188; Nelson, 'Missionaries and the Aborigines', p.60n
} 
tribe'. ${ }^{107}$ Bourke replied: 'the separation of tribes can only proceed on the ground of this being necessary in order to secure peace ... it is anxiously hoped [this] will not be the case'. ${ }^{108}$ Despite the hopes of the governor, Langhorne found that he had to confine his efforts to one language group or face violence at the mission station. ${ }^{109}$ Thus his evangelical efforts were 'necessarily confined to one tribe' as other language groups 'will venture but seldom into the districts of our blacks' ${ }^{110}$

At the beginning of 1838 Langhorne was, in addition to his mission duties, temporarily given charge of the Native Police, the colonial attempt to utilise Aboriginal violence examined in chapter five. 'In endeavouring to extend the sphere of my labours to the neighbouring tribes', Langhorne concluded in summing up his experiences as a missionary when the government mission was closed, 'and to enable the [surrounding language groups] ... to participate in the benefits of the Mission Station, I found that the constant petty contentions and strife in which these tribes are continually embroiled with one another frustrated every attempt to bring them together in peace even occasionally'. ${ }^{111}$ After the close of the mission Langhorne undertook a pastoral venture with his brothers. When this failed financially, the former missionary believed it was divine retribution for his earlier evangelical failure. ${ }^{112}$

Aboriginal beliefs surrounding death also retarded philanthropic attempts to suppress internecine Aboriginal killings, and indeed wider attempts to 'civilise' and Christianise Aboriginal peoples. As Curr observed, one widespread Aboriginal custom 'was to avoid mention of the dead under all circum-

\footnotetext{
107 Langhorne to Bourke, 26 November 1836, HRV2A, pp.157-158

108 Colonial Secretary's Draft Memorandum, 9 December 1836, HRV2A, p.164, emphasis in original

109 Langhorne, statement, 1836; Langhorne to col. sec., 28 February $1838-H R V 2 A$, pp.176 \& 211

110 Langhorne to col. sec., 30 April 1838, HRV2A, p.215

111 Langhorne to La Trobe, 15 October 1849, HRV2B, p.509; see also: Foxcroft, pp.23-25 \& 48

112 Gunson (ed.), Australian Reminiscences, ii:pp.326-327
} 
stances'. 'Nothing jarred on the feelings of the Blacks more than to hear a white man name the dead, even by his white name', the squatter concluded, noting that 'a sort of horror came over them on such occasions, and they would endeavour to stop the speaker's mouth with their hands'.113 In discussing the motives which render these savages so averse to speak of the dead', Howitt cited one occasion 'when one of the Kŭrnai was spoken to about a dead friend, soon after the decease, he said, looking around uneasily, "Do not do that; he might hear you and kill me!"'114 Missionaries could not discuss Christianity without talking about death and behaving well in life, including being non-violent, in order to get to heaven, and this made attempting to Christianise Aborigines difficult.

There were, however, rarely-used means to circumnavigate this difficulty. As Hilary Carey observes, a number of Awabakal adopted 'tetti', an English loanword from 'death', in order to be able to circumvent traditional laws and discuss death with Threlkeld at his LMS Lake Macquarie mission. ${ }^{115}$ While, as Carey suggests, this is reflective of Threlkeld's role as an interpreter for the Supreme Court, it also highlights the complex cross-cultural difficulties faced by evangelicals in attempting to discuss death, and the violence which led to it, with Aboriginal peoples. Jean Woolmington suggests that missionaries 'continually talked of death and the importance of preparing for the life to come, though the Aborigines were terrified of this subject and invariably asked the missionaries to desist'. ${ }^{116}$ As Ferry observes, 'the entire Christian

\footnotetext{
${ }^{113}$ Curr, Recollections of Squatting, pp.127-128

114 A.W. Howitt, 'On Some Australian Beliefs', pp.190-191; Broome, Aboriginal Australians, p.21; Dredge, Brief Notices, pp.7-8

115 Hilary M. Carey, 'Death, God and Linguistics: Conversations with Missionaries on the Australian Frontier, 1824-1845', Australian Historical Studies, 40:2, 2009, pp.167-168; L.E. Threlkeld, An Australian Grammar: Comprehending the Principles and Natural Rules of the Language, as Spoken by the Aborigines, in the Vicinity of Hunter's River, Lake Macquarie, \&c., New South Wales, Sydney:1834, pp.126-127

116 Jean Woolmington, 'Early Christian Missions to the Australian Aborigines', VHM, 26, 1974, p.4
} 
message with its complex concepts of sin, repentance, redemption, resurrection, grace etc. relied on a contemplations of one's own death and the consequences'. ${ }^{117}$ A clearly frustrated J.C.S. Handt, missionary at Wellington Valley, observed in his journal that Aboriginal peoples 'are justified with a great fear of death; and yet it is impossible to speak to them about religion, even with regard to the joys of heaven, without teaching them the point of death'. ${ }^{118}$ While the example of Threlkeld shows the possibility of Aboriginal adaption in response to this challenge, a fundamental cultural difference existed between Europeans and Aboriginal peoples regarding death, and this affected evangelicals' efforts in New South Wales and wider-Australia.

While one of the primary aims of the protectors was the suppression of Aboriginal violence, sometimes, when Europeans attempted to implement this goal, Aborigines themselves employed another of the aims of the Protectorate as a threat to counter critiques of their traditional violence. When Mr. Blomfield interrupted a group of Mount Rouse Aborigines who had come on his station and killed three Aborigines who lived there, he claimed had it not been for his intervention the 'savage Cannibals likely would have destroyed a tribe of poor quiet harmless people'. Having been informed of this incident, an infuriated Geelong Police Magistrate Foster Fyans relayed the narrative to La Trobe, noting that upon being interrupted by squatters in their inter-language group disputes, Aborigines frequently asserted to the meddling Europeans that if the settlers harmed them in preventing their traditional rivalries, then Assistant Protector Sievwright would hang them. ${ }^{119}$ In early1840, Tuckfield complained to his colleague Hurst that there was 'a wrong impression resting on the minds of the Woddowro [Wathaurong] tribe'.

\footnotetext{
${ }^{117}$ Ferry, p.33

118 Handt, journal, 14 October 1835, Hilary M. Carey and David A. Roberts (eds.), The Wellington Valley Project. Letters and Journals Relating to the Church Missionary Society Mission to Wellington Valley, NSW, 1830-45. A Critical Electronic Edition, 2002

${ }^{119}$ Fyans to La Trobe, July 1842, cited in Corris, pp.88-89
} 
'They think whatever they do wither it be to the whites, or to the blacks or any other tribe they can take shelter under the wing of the Protector of Aborigines', the missionary lamented, 'and under the influence of this some of them appear to be acting' ${ }^{120}$ Aborigines were quite willing to employ the Protectorate in order to maintain their traditional animosities without the interference of Europeans, settler or missionary.

In addition to the flour, tea, sugar, new meats, alcohol, and diseases European contact introduced to Aboriginal societies, some Aborigines also obtained firearms from Europeans. The Aboriginal possession of firearms often created panic among Europeans, which in turn led to further attempts to suppress Aboriginal violence.

A month after having arrived in Melbourne, the assistant protectors encountered four Wathaurong men, who entered the colonial officials' camp carrying, among their traditional weapons, a musket. ${ }^{121}$ Thomas wrote: '[n]o small degree of anxiety was created among us, especially the ladies, more so as they came at dark, and well armed with spears, shields, waddies, \&c. One had a musket.' The protectors set a rotating watch and, perceiving the major threat to their safety to be the non-traditional weapon, endeavoured 'to get the gun away from them'. They were very much relieved to find the musket was defective. ${ }^{122}$

In his September 1838 mission report Langhorne noted that '[a] considerable number of the blacks obtain food and clothing for themselves by shooting

\footnotetext{
120 Tuckfield to Hurst, 17 January 1840, MS-7667:Box-655, SLV

121 Dredge recalled two muskets, Thomas one; Dredge, diary, 4 February 1839, MS-5244, SLV

122 Thomas, journal, 5 January 1839, HRV2B, p.437
} 
the Menura Pheasant or Bullun Bullun [lyrebird] for the sake of the tails, which they sell to the whites.' ${ }^{\prime 23}$ The following January, having been informed that he was to 'discountenance in every way the shooting of pheasants by the blacks', Langhorne reported: '[w]ith regard to the blacks having firearms in their possession, I have ever discouraged it in every way'. The missionary asserted 'it has frequently been mentioned by the blacks as a reason for their not frequenting the Mission Station that I constantly refused them firearms, whereas the black police were so armed and the other natives could obtain muskets from the settlers whenever they required them'. Such was the Aborigines' passion for firearms, he believed, that anyone who wished to could secure the attendance of Aborigines whenever they liked 'merely by supplying them with guns and ammunition'. ${ }^{124}$

Soon after the beginnings of colonisation in Port Phillip, enterprising settlers in the district began supplying Aborigines with firearms in order to hunt lyrebirds for their tail-feathers - a popular fashion accessory among the colonists. "Tis well for people in Melbourne ... to give [Aborigines] firearms', Thomas complained, '[t]hey are safe in Melbourne, but people in the bush are exposed to their fickle whim, \&c.' ${ }^{\prime 25}$ In August 1840 'An Act to prohibit the Aboriginal Natives of New South Wales from having Fire Arms or Ammunition in their possession without the permission of a Magistrate' was proclaimed by colonial administrators. ${ }^{126}$ Aboriginal possession of traditional weapons, on the other hand, was not outlawed. Although the Act was disallowed by the Crown the following year, as it contrasted with the insistence that Aboriginal peoples were British subjects and should be treated as such, Europeans who supplied Aborigines with firearms continued to be

\footnotetext{
123 Langhorne to col. sec., 30 September 1838, HRV2A, p.229; Gaughwin and Sullivan, p.90

124 Langhorne to col. sec., 31 January 1839, HRV2A, p.235

125 Thomas, journal, 21 September 1839, HRV2B, p.545

126 Supplement to New South Wales Government Gazette of 26 August 1840, 29 August 1840, pp.837-338; Bridges, 'Aborigines and the Law', pp.64-65
} 
classed as traitors and publicly ostracised. Thus, where colonial government legislation failed, moral and social pressure greatly reduced the number of firearms acquired by Aborigines. ${ }^{127}$

In a diffuse and repetitive letter dated 8 July 1839 the chief protector advised his assistants that they were to prohibit Aborigines possessing firearms. Although Robinson noted that his attention to the subject was drawn by settler fears of Aborigines armed with European weapons, this prohibition, he believed, was further necessary to suppress Aboriginal violence. '[T] here is too much reason to fear', he wrote,

that the possessors of those guns have turned them against their own race, and that they have been taken advantage of by them to satiate their own revengeful feelings against some unfortunate tribe with whom they have been at variance, as I am led to believe, numerous Aborigines have already fallen victims to their unerring and deadly effects.

The chief protector had heard reports, including from Aborigines themselves, that 'nefariously disposed white persons had prompted them on and instigated them to the commission of those direful practices' - 'namely the furnishing of firearms and ammunition to one tribe of aboriginal natives to destroy another'. ${ }^{128}$

Leading up to the 1840 prohibition, a correspondent for the Port Phillip Gazette vociferated settler anxiety at the Aboriginal possession of firearms. 'Sheep to the amount of seven or eight hundred head, valued ... at fifteen or sixteen hundred pounds, have been carried off or destroyed', it was alleged. Describing Aboriginal attempts to cope with the rapid invasion of their

127 Port Phillip Gazette, 6 April 1842, p.3, SLV; Christie, pp.68-69; Crawford, pp.100-105; Arkley, pp.132-143

${ }^{128}$ Robinson to assistant protectors, 8 July 1839, HRV2B, pp.724-727; Robinson, journal, 9 July 1839, MS-9974:CY-424, SLV 
country, the writer concluded: 'the Aborigines are met with in every part collected in large bodies and armed with Europeans weapons, they evince the greatest treachery and hostility, commit daily the most daring acts of robbery, and leave the country in a state of the greatest excitement and alarm'. ${ }^{129}$

Meanwhile, the chief protector explained the reasoning behind his belief in the need to prohibit Aboriginal peoples possessing firearms. He felt that Aborigines could not be entrusted with guns because '[t]heir ideas of morality and notions of rectitude are of the most vague and uncertain description.' He therefore advised the assistant protectors to seek the aid of the constabulary in effecting the confiscation of firearms because Aborigines were likely to be displeased with said confiscation, and using police would, he hoped, save creating animosity towards the protectors. The assistant protectors were thus requested 'to adopt such measures as shall in future put a stop to this exterminating process so that peace and tranquillity may be restored to contending tribes and war no more'. ${ }^{130}$ Providing insight into the problems of the Protectorate, when Robinson forwarded a copy of these important philanthropic instructions to the colonial secretary for the information of the governor, the colonial secretary quipped: ' $[\mathrm{w}] \mathrm{e}$ shall I think soon have to forbid this gentleman the use of pen and ink.' ${ }^{131}$

Aboriginal peoples occasionally incorporated firearms into their subsistence, adapting in order to cope with the swift and substantial changes the arrival of Europeans brought. Aborigines used firearms to shoot lyrebirds in order to trade their tails with Europeans for money, food, tobacco, clothing, and other goods. They also used firearms to hunt their traditional game, which

\footnotetext{
129 Port Phillip Gazette, 14 August 1839, p.2, SLV

130 Robinson to assistant protectors, 8 July 1839, HRV2B, pp.724-727; Robinson, journal, 9 July 1839, MS-9974:CY-424, SLV

131 Robinson to col. sec. 8 July 1839, HRV2B, p.727, see also: Corris, pp.151-152; Rae-Ellis, p.194; and Gipps' disinterest in Robinson's reports observed in Clark (ed.), 'In Quest of the Tribes', p.99
} 
was becoming increasingly scarce as a result of the rapid expansion of European pastoralism. As such, many Aborigines were furious when informed they were no longer allowed to possess guns. Thomas reported: “"[n]o no no," one and another cried, "By and bye big one hungry me"”. ${ }^{132}$ The assistant protector believed, and often noted, that the order to seize all firearms in Aboriginal possession would cost him his life. ${ }^{133}$

In the 1836-1837 Report from the Select Committee on Aborigines (British Settlements) it was lamented that indigenous peoples throughout British colonies 'have been familiarized with the use of our most potent instruments for the subtle or the violent destruction of human life, viz. brandy and gunpowder'. Within their promotion of the 'civilization', Christianisation, and protection of indigenous peoples, the parliamentary select committee observed that '[ $t$ ]he prohibition of the sale of ardent spirits, or the delivery of them to the natives in barter, is an object of the deepest interest'. While acknowledging the difficulties faced in effecting such a ban, the committee urged local governments in the colonies to remember 'that for the extermination of men who are exempt from the restraints both of Christianity and of civilization, there is no weapon so deadly or so uncertain as the produce of the distilleries'. ${ }^{134}$ As James Anthony Froude observed with regard to 'Kaffirs' drinking alcohol under British and Dutch colonial rule on his 1874 visit to southern Africa: '[i]f rum and brandy, why not strychnine at once?' 135 For numerous reasons, many Europeans supplied Aboriginal peoples with alcohol and firearms. ${ }^{136}$ At the same time, philanthropists on the one hand begged Aborigines to

\footnotetext{
132 Thomas, journal, 6-7 October 1839, HRV2B, pp.550-551

133 Thomas, journal, 20 November 1839; Thomas to Lonsdale, 9 November 1839; Thomas to Robinson, 29 February 1840 - HRV2B, pp.564, 601 \& 619-620; Ellender and Christiansen, pp.67-68

${ }^{134}$ Report from the Select Committee on Aborigines, ii:pp. 5 \& 78

135 J.A. Froude, Short Stories on Great Subjects, London:1894, p.479

136 Langton, 'Run, Seduction and Death', p.196; Bridges, 'Aborigines and the Law', p.43; Blaskett, pp.293-310
} 
emulate Europeans, but on the other not to drink alcohol and shoot guns, as so many Europeans whom they encountered did.

Lucy Edgar, daughter of the Baptist Merri Creek School schoolmaster who taught at the school from 1848-1851, recalled that as part of their education, young Aboriginal men who attended the school had an illustrated alphabet. This learning aid included a page detailing that ' $\mathrm{P}$ is for Publican', accompanied by a picture of 'a very corpulent man, with more body than his legs seemed able to carry'. The Aboriginal students evidently found this picture hilarious - so much so that they named their fat pig Publican. 'Him Publican keep house sell rum?', the students enquired of the illustration, to which the reply was yes. ${ }^{137}$ The demand that Aborigines not drink alcohol was beset with contradictions, not least that apparently 'publican' was such an important illustrative $\mathrm{p}$-word to the society they were being encouraged to emulate. ${ }^{138}$ At Lake Macquarie Threlkeld scolded a group of Aborigines for being intoxicated, only to be 'informed by one of the natives that ... they only affected drunkenness in consequence of a desire to appear like white men'. ${ }^{139}$

The perceived need to prevent Aboriginal consumption of alcohol arose from the belief that intoxication increased Aboriginal violence. As Broome observes of the colonial period: '[ $t$ ]here are no accounts of sensible use of alcohol by Aborigines - perhaps it was not thought worthy of reporting - but plenty about alcohol abuse.' ${ }^{140}$ Supplying Aborigines with alcohol was

\footnotetext{
137 Lucy Edgar, Among the Black Boys; Being the History of an Attempt at Civilising some Young Aborigines of Australia, London:1865, pp.17-18; Clark and Heydon, p.3; Foxcroft, pp.91-99

${ }^{138}$ As Threlkeld observed, the contradiction went further than Aboriginal-European relations. 'Rum, as the strongest inducement [to labour] that could be offered to the aborigines used to be the temptation held out as the most likely to prevail. It must however be remembered that formerly this was a Rum-colony ... Rum built our hospitals, Rum built our palaces, Rum erected churches, and Rum was the circulating medium, which even paid preachers to teach men "to live soberly righteously, and godly, in this present evil world'; Threlkeld, Reminiscences, i:p.53, emphasis in original

139 Threlkeld, Reminiscences, i:p.54n

140 Broome, Aboriginal Victorians, p. 25
} 
banned in New South Wales in 1838 under threat of a $£ 5$ fine; however, owing to an unwillingness to police this, the ban had little effect, although the discouragement of Aboriginal Elders did stem the flow. ${ }^{141}$ In November 1839 Thomas complained of 'two blacks beastly drunk who acted more like maniacs'. 'I learnt from the blacks who supplied them with liquor', he wrote, 'but what avails this information? Not a constable will assist a Protector.' Three days later Thomas further complained that he was up until two o'clock in the morning because three Aboriginal men were intoxicated, and he 'thought that some murder would have been before the morning, for when drunk they are like maniacs'. Another two days later he reported that he was up until three o'clock in the morning protecting an Aboriginal woman whose son was drunk and threatening to spear her. 'Drunkenness and swearing is all that these people seem to have learned', the assistant protector lamented, that 'and firing off a gun.'142

On 29 June 1849 a New South Wales Legislative Council select committee was appointed 'to enquire into the state of the aboriginal inhabitants of this colony, more especially with regard to the success or failure of the present protectorate system in Port Phillip'. The select committee distributed questionnaires to a number of magistrates, and engaged in further correspondence with squatters, crown land commissioners, and clergy. Under the guidance of this correspondence, which had been almost unanimous in condemning the Protectorate, the committee concluded: 'the present system of protection of the Aborigines has totally failed in its object'. The committee

\footnotetext{
${ }^{141}$ Supplement to the New South Wales Government Gazette of 24 October 1838, 27 October 1838, pp.904-905; Broome, Aboriginal Victorians, pp.24-26; Cranston, pp.67-68\&72; Clark, iii:p.110

142 Thomas, journal, 6-11 November 1839, HRV2B, pp.557-559; see also: Thomas to Robinson, 10 November 1839, VPRS-13172, unit-1:discs-13-14, PROV
} 
felt 'compelled to advise the abolition of the present system' of Aboriginal protection, adding they were 'unable to recommend any other as a substitute'. ${ }^{143}$ Governor Gipps, under whom the Protectorate had been established, had earlier complained: '[t]he course pursued by the protectors, had been ... one from the beginning of feeble action and puling complaint' ${ }^{144}$ Typical settler opinion in the district is perhaps best represented by squatter George Russell, who told the select committee that the money spent on the Protectorate may as well have been 'thrown into the sea'. ${ }^{145}$

In 1850, Thomas reported that Aboriginal peoples of Melbourne and Westernport told him that they delighted in expeditions to Gippsland because squatters there gave them access to firearms with which to attack their traditional enemies, the Kurnai. ${ }^{146}$ The protectors sought to suppress this settlersponsored internecine violence, though, as is examined in chapter five, colonial officials simultaneously sought to utilise traditional Aboriginal animosity. Despite the efforts of protectors and missionaries, Aboriginal violence persisted in the district into the 1850 s. $^{147}$ Although by this time many Woiworung were working for Europeans as pastoral and agricultural labourers, they still fought with their traditional enemies the Kurnai. ${ }^{148}$ Nance has identified a minimum of 96 Aborigines who were killed by other Aborigines in Port Phillip between 1836 and 1850, but adds that the real figure could be 'possibly 200 or more'. In an earlier work she suggested a minimum of 250 Aborigines were killed by other Aborigines during this period. She asserts

\footnotetext{
143 Sydney Morning Herald, 2 July 1849, pp.2-3 \& 20 September 1849, p.2; Christie, pp.105-106; Cannon, Who Killed the Koories?, pp.255-256; Corris, pp.121-124; Clark and Heydon, p.74; Foxcroft, pp.72-78 \& 101-102; Mitchell, 'The galling yoke of slavery', pp.126-131; Twomey, pp.111-112

144 quoted in Lester, 'British Settler Discourse', p.41

145 quoted in Cannon, Who Killed the Koories?, p.255

146 Broome, 'Struggle for Australia', p.118

147 Nance, p.538; Thomas, 'Brief Account', pp.416-418; Barta, pp.531-533

148 Richard Broome, 'Victoria', in Ann McGrath (ed.), Contested Ground: Australian Aborigines under the British Crown, Sydney:1995, p.134
} 
that more Aborigines were killed by internecine violence than the 59 Europeans she finds were killed by Aborigines in the same period. ${ }^{149}$ The debate over precise numbers killed can detract from the brutal reality of frontier violence, ${ }^{150}$ but it is clear Aborigines were more willing or better able to kill other Aborigines than to kill Europeans in the early-contact period. On the other hand, many more Aborigines were killed by settlers than by other Aborigines, which led to forced migration into foreign country, which in turn furthered intra-Aboriginal violence.

Within their endeavours to 'civilise', Christianise, and protect the Aboriginal people of the Port Phillip District of New South Wales, both protectors and missionaries focussed much of their effort on suppressing Aboriginal violence. Finding their efforts to do so using Aboriginal peoples' supposed status as British subjects frustrated, the philanthropists used their overarching ambition of 'civilising' and Christianising Aboriginal peoples as a means of achieving their goal. Thus a paradox developed: to be converted into 'civilised' Christians, Aborigines had to be made to end their violence, yet as a means of ending Aboriginal violence, protectors and missionaries sought to 'civilise' and Christianise Aborigines.

Aborigines were, however, often confused at European attempts to suppress their traditional means of resolving conflict, particularly as they often perceived British justice to be barbaric and unnecessarily violent. Moreover, the very presence of Europeans, necessary for Aboriginal 'redemption', was itself exacerbating Aboriginal violence: squatters forced Aboriginal peoples into foreign country; European settlements attracted Aborigines, who

\footnotetext{
149 Barwick, with little supporting evidence, argues Nance exaggerated Aboriginal violence; Nance (née Blaskett), passim, esp. pp.553 \& 549; Blaskett, passim, esp. pp.311-312 \& 356; Barwick, 'Mapping the Past', p.109n; Richard Broome, 'Aboriginal Victims and Voyagers, Confronting Frontier Myths', Journal of Australian Studies, 18:42, 1994, p.73n

150 Belich, Replenishing the Earth, pp.552-553
} 
crossed, then congregated in, foreign country; and philanthropists, both in the guise of government protectors and evangelical missionaries, encouraged Aboriginal peoples to settle together, regardless of traditional inter-language group animosities. Meanwhile, as is explored in chapter five, while protectors and missionaries were attempting to suppress Aboriginal violence, the colonial government was simultaneously seeking to utilise Aboriginal violence for the promotion of colonisation. 


\section{Chapter Four \\ '[S]words and spears into hooks and plough shares': the Suppression of Māori Violence}

Wishing to hail a ship while visiting the Bay of Islands with Marsden in 1814-1815, Englishman J.L. Nicholas borrowed a pistol from Ngāpuhi rangatira Ruatara to discharge from the beach. When Nicholas pulled the trigger, the pistol flew out of his hand and hit him in the forehead, causing a wound which bled profusely. The European explanation for the accident was that Ruatara had loaded the weapon with an excess of gunpowder. While Marsden washed and bound the wound, however, the temporarily insensible Nicholas was told that his misfortune was just punishment for his using a tapu (sacred) firearm. ${ }^{1}$ Prior to European contact, Māori violence was strictly governed by customs, rituals, and beliefs. ${ }^{2}$ Although, as Nicholas discovered, tikanga regarding weaponry and warfare did not drastically alter postcontact, the introduction of firearms did increase the frequency of Māori warfare and the scale on which it was fought.

Māori fascination with firearms developed quickly in the early-nineteenth century and pū (firearms) were fast incorporated into Māori society. With the increased availability of firearms, inter-iwi conflict increased markedly in the 1820s. ${ }^{3}$ Accompanying the introduction of firearms and the associated

\footnotetext{
1 Nicholas, ii:pp.190-192

2 Belich, Making Peoples, p.78; Best, 'Omens and Superstitious Beliefs', pp.119-136; cf. A.P. Vayda, 'Maori Conquests in Relation to the New Zealand Environment', JPS, 65:3, 1956, pp.204-211; A.P. Vayda, 'Maoris and Muskets in New Zealand: Disruption of a War System', Political Science Quarterly, 85:4, 1970, pp.561-571; Vayda, Maori Warfare, passim

3 Ballara, 'Role of Warfare', pp.487-506; Ballara, Taua, passim; Harrison M. Wright, New Zealand, 1769-1840: Early Years of Western Contact, Cambridge, Massachusetts:1959, pp.81-102 \& 119-122; Gordon Lewthwaite, 'The Population of Aotearoa: its Number and Distribution', New Zealand Geographer, 6:1, 1950, pp.35-52; Hill, Policing the Colonial Frontier, i:pp.44-45; D.U. Urlich, 'The Introduction and Diffusion of Firearms in New Zealand 1800-1840', JPS, 79:4, 1970, pp.399-410; D.U. Urlich, 'Migrations of the North Island Maoris 1800-1840: a Systems View of Migration', New Zealand Geographer, 28:1, 1972, pp.23-35; Vayda, 'Maoris and Muskets', pp.571-584; Vayda, Maori Warfare, pp.4
} 
increase in Māori violence was an evangelical and later an official desire to suppress intensified Māori conflict.

From the beginning of the nineteenth century, European traders and whalers provided Māori with pū in return for prostitutes, pigs, potatoes, and other produce. Clarke (junior) - whose heritage as the son of a gunsmith was used against him in attacks on his role as a colonial official - further claimed that Māori first obtained firearms by stealing them from visiting Europeans. ${ }^{4}$ Missionaries, too, were compelled to trade muskets with Māori. Because the land at Rangihoua allocated to the CMS by Ruatara, on which the first mission station sat, was extremely steep, attempts at cultivation were highly unproductive. ${ }^{5}$ Later, even with their own gardens established, the evangelicals relied on Māori for meat. ${ }^{6}$ Concerned with feeding her family, Henry Williams' wife Marianne wrote in her journal: '[t]he chiefs say that they will bring us no pigs unless we sell muskets'. ${ }^{7}$ The missionaries thus depended on Māori for survival - 'forced to realize that the gun was the coin of this realm'. ${ }^{8}$ Marsden himself had even engaged in supplying Māori with muskets, as the Reverend John Butler reminded the CMS secretaries at the expense of his employment. ${ }^{9}$ As their desire for firearms developed, Māori in-

\& 80-83; cf. J.M.R. Owens, 'Christianity and the Maoris to 1840 ', NZJH, 2:1, 1968, pp.32-33; S.P. Smith, Maori Wars, pp.16-19

${ }^{4}$ Chief Protector Clarke's history as a gunsmith was also used in attacks on him; Clarke (junior), Notes, pp.6 \& 49-50; New Zealand Spectator and Cook's Strait Guardian [NZSCSG], 22 November 1845, p.2; Trevor Bentley, 'Acculturating Heavy Metal: the Role of the Tribal Artillery in the New Zealand Musket Wars', New Zealand Legacy, 7:2, 1996, p.14; Mark Hickford, Lords of the Land: Indigenous Property Rights and the Jurisprudence of Empire, Oxford:2011, p.190

${ }^{5}$ On the CMS 'purchase' of land at Rangihoua see: British Parliamentary Papers (Irish University Press Series), Colonies, New Zealand (BPP), 17 vols., Shannon:1968-1971, i:pp.164-165

6 Lawrence M. Rogers, Te Wiremu: a Biography of Henry Williams [1973], Christchurch:1998, pp.38-39, 57 \& 67; Judith Binney, 'Christianity and the Maoris to 1840: a Comment', NZJH, 3:2 1969, pp.144-147; Binney, Legacy of Guilt, passim, esp. p.46; Wright, New Zealand, pp.86-90 \& 133-140

7 quoted in Hugh Carleton, The Life of Henry Williams: Archdeacon of Waimate, 2 vols., Auckland:1874 \& 1877, i:p.31

8 Binney, Legacy of Guilt, pp.53-54 \& 59-63

9 Wright, New Zealand, pp.41-42; Dorothy Urlich Cloher, Hongi Hika: Warrior Chief, Auckland:2003, p.210; O'Malley, pp.137-138 
creasingly demanded muskets and gunpowder as the only form of payment acceptable for supplies vital to the missionaries' survival, and necessary for traders' and whalers' profits.

Evangelical missionary effort in New Zealand coincided with the incorporation of firearms into Māori society. Evangelicals saw the suppression of Māori violence, which was rapidly increasing as muskets were integrated into traditional Māori warfare, as a necessary requirement in their desire to 'civilise' and Christianise Māori. Later, colonial officials also sought to suppress Māori violence as they looked to extend British control over New Zealand. This evangelical and colonial official desire to suppress Māori violence is here explored through an examination of missionary responses to the Musket Wars and the establishment of the Aboriginal Protectorate in the wake of the signing of te Tiriti o Waitangi.

In this chapter it is argued that much evangelical, and later colonial official, effort directed towards Māori focussed on the attempted suppression of Māori violence, which European contact greatly exacerbated. While this attempted suppression was often successful, the reasons for its success were complex. It is here argued that the Musket Wars came to an end when all iwi had roughly equal access to muskets, a saturation of firearms thus removing the advantage which had sparked the wars. In the same way that an uneven distribution of muskets began the wars, however, an uneven distribution of peace would have further promoted warfare - if one iwi had declared peaceful intentions and disarmed before its rivals did so, it would then became susceptible to attack. When requested by Māori, the intervention of missionaries played a central role in a more even distribution of peace. Later, as the Crown sought to establish and enforce British law in New Zealand, colonial officials too sought to suppress Māori violence. It is in this chapter further 
argued that when their intervention was not requested by Māori, missionaries and colonial officials - the protectors of aborigines especially - were often unsuccessful in their attempts to suppress Māori violence and subject internecine Māori 'crime' to British law.

The first recorded use of firearms in Māori warfare was an 1807 conflict at Moremonui in which a Ngāpuhi tauā attacked a section of Ngāti Whatua using a small number of muskets. The Ngāpuhi tauā, which included a young Hongi Hika, was defeated despite its muskets. Two of Hongi's brothers were killed, and Hongi himself reportedly only escaped death by swimming away using a hollow reed to breathe while remaining completely submerged beneath the water. Despite the Ngāpuhi defeat and his near death, Hongi was quick to realise the potential of firearms in Māori warfare. ${ }^{10}$

When Marsden visited Kaipara in 1820, Ngāti Whatua recounted to him their 1807 victory. They informed the chaplain that 'they were now much in alarm, as Shunghee[Hongi]'s tribe were well armed with musket and powder, while they had none to defend themselves against their enemies'. ${ }^{11}$ At the very moment Ngāti Whatua were relaying their fears to the founder of the New Zealand mission, Hongi was in England acquiring the means of obtaining many more muskets.

When Thomas Kendall first met Hongi in June 1814, the Ngāpuhi rangatira had a musket on his person and told the missionary that he owned ten

\footnotetext{
10 Marsden, 3 May 1820, Letters and Journals, pp.242-243; Urlich Cloher, Hongi Hika, pp.36, 5257 \& 233-234; Jeffrey Sissons, Wiremu Wi Hongi, and Pat Hohepa, Ngā Pūriri o Taiamai: a Political History of Ngā Puhi in the Inland Bay of Islands [1987], second edition Auckland:2001, p.25; S.P. Smith, Maori Wars, pp.31-49

11 Marsden, 15 November 1820, Letters and Journals, p.319
} 
more. ${ }^{12}$ It was Hongi, who had visited Port Jackson earlier that year, under whose protection the CMS mission in New Zealand operated after the death of Ruatara in March 1815. Kendall was appointed justice of the peace in 1814, and the following year New South Wales Governor Lachlan Macquarie instated Hongi, Ruatara, and Korokoro as constables. ${ }^{13}$ Due to the delay of sending and receiving documents from Sydney and his inability to detain suspects, having neither a gaol nor leg-irons and handcuffs, however, Kendall's title was ineffectual. As Hill demonstrates, Kendall was powerless to prevent Constable Hongi Hika from undertaking a tauā to the East Coast in 1818 during which his toa are said to have destroyed some 500 kāinga (villages). ${ }^{14}$ When Kendall returned from England, freshly ordained, in 1821 he brought with him 21 muskets, which he gifted to various Bay of Islands rangatira. Hongi returned from the same voyage with some 300 muskets. ${ }^{15}$

As is demonstrated in this chapter, August Earle's contemporaneous claim that Māori invariably 'made a sad bungling use of the musket' must be disregarded. 'The New Zealander, while handling a musket', Earle asserted, 'is in quite a state of trepidation; and though it is his darling weapon, he seems always afraid of it, and is never sure of his aim till he is quite close to his object.' The artist further claimed Māori were constantly damaging their muskets through taking apart, cleaning, and reassembling the weapons too often. ${ }^{16}$

\footnotetext{
12 Salmond, Between Worlds, pp.437-438

13 'Government and General Order', 9 November 1814, HRNZ, i:pp.328-329; Hill, Policing the CoIonial Frontier, i:pp.35-40; Alan Ward, A Show of Justice: Racial 'Amalgamation' in Nineteenth Century New Zealand, Canberra:1974, p.14; Belich, Making Peoples, p.157; O’Malley, p.75

14 Hill, Policing the Colonial Frontier, i:pp.38-42

15 ibid., i:p.45; Trevor W. Bentley, 'Tribal Guns, Tribal Gunners: a Study of Acculturation by Maori of European Military Technology during the New Zealand Inter-Tribal Musket Wars', MA thesis, University of Waikato:1997, p.32; Earle, pp.62-63; Binney, Legacy of Guilt, pp.68-79; Urlich Cloher, Hongi Hika, pp.119-148; Wilson, From Hongi, pp.15-35

${ }^{16}$ Earle, pp.72-73
} 
Trevor Bentley argues that European traders rarely supplied Māori with guns of a superior quality before the 1830s; not because of a fear that Māori would turn these firearms against Europeans, rather because poor quality muskets needed replacing often, thus ensuring greater profits for traders. For this reason, he suggests that while rangatira possessed fine, well-made muskets during the Musket Wars, toa were generally armed with cheaper, poorly-made firearms. Bentley further argues that these inferior muskets were not leftover arms from the Napoleonic Wars, as might be expected, rather they were cheaper weapons made especially for trading with indigenous peoples in Africa and other parts of the world being penetrated by Europeans. ${ }^{17}$ While this may have initially been the case, Belich believes that there was an upsurge in the quality and quantity of firearms from 1818, when Europeans began selling off surplus war arms. This increased supply led to a sharp decline in the price Māori paid for muskets. ${ }^{18}$

Bentley finds it surprising that the muskets supplied to Māori killed at all, because they were so 'grossly inaccurate' and of 'poor quality and limited power'. Moreover, flintlock muskets became very hot to the touch when in use, and sparks and smoke would have affected the vision of those firing them. Added to this discomfort was an intense thirst as men biting their cartridges got saltpetre in their mouths. ${ }^{19}$ Given the unknown element of firearms faced by defending Māori who had not yet encountered the weapons, and that attacking Māori increasingly adapted traditional warfare techniques to effectively incorporate firearms, however, muskets certainly contributed to a shift in the balance of power towards those iwi who acquired guns. Muskets, of course, had often killed tens of thousands of men on European

\footnotetext{
17 Bentley, 'Tribal Guns, Tribal Gunners', pp.2-24

18 James Belich, personal communication, 2 April 2012

19 Bentley, 'Tribal Guns, Tribal Gunners', p.113; Paul D'Arcy, 'Maori and Muskets from a PanPolynesian Perspective', NZJH, 34:1, 2000, pp.123-126; Wright, New Zealand, pp.84-85
} 
battlefields during the Napoleonic Wars. The maintenance of traditional methods of warfare in combination with an adapting use of muskets overcame any shortcomings of poor quality guns. Many Māori in under-armed or musketless iwi were killed both directly and indirectly by pū.

Despite his dismissal of Māori ability regarding firearms, upon arriving in the Bay of Islands in 1827 Earle noted that ' $[t]$ he first thing which struck me forcibly was, that each of these savages was armed with a good musket, and most of them had also a cartouch box buckled round their waists, filled with ball cartridges'. He further observed:

[f]rom the length of time these people have been known to the Europeans, it might naturally be expected that great changes would have taken place in their habits, manners, arts, and manufactures; but this is not the case ... The only material change that has taken place is in their mode of warfare. The moment the New Zealanders became acquainted with the nature of fire-arms, their minds were directed but to one point; namely, to become possessed of them.

'In their combats with each other', Earle continued, 'fire-arms are used with dreadful effect. The whole soul of a New Zealander seems absorbed in the thoughts of war; every action of his life is influenced by it; and to possess weapons which give him such a decided superiority over those who have only their native implements of offence, he will sacrifice every thing.' Ever the artist, Earle further mentally contrasted the 'tranquil beauty' of the New Zealand landscape and wildlife with 'the difficulties and dangers I might have to encounter from hordes of ferocious savages, who, now flushed with conquest, were plotting murder and destruction against each other' ${ }^{20}$

\footnotetext{
20 Earle, pp.10, 56-58, 224-225 \& 284; see also: Elsdon Best, The Maori, 2 vols., Wellington:1924, ii:pp.284-285; Sydney Herald, 11 May 1837, p.2
} 
An unidentified Māori raconteur later told scholar, linguist, and colonial administrator John White of his travels with Hokianga Ngāpuhi as they raided down the west coast of Te Ika-a-Māui from Hokianga to Te Whanganui-ā-Tara in 1819 and 1820. The tauā had only four muskets; nevertheless these had a massive impact on the raids. When the Ngāpuhi arrived outside an enemy pā, White was told, the best toa of the enemy hapū would race to the highest point in the pā to challenge the approaching tauā. Ngāpuhi marksmen would then employ their four muskets to shoot the challenging toa.

Those braves did not know of the gun, nor of its deadly effects ... It was just like a pigeon falling out of a tree! When the others heard the noise, saw the smoke and the flash, and the death of their braves, they thought it must be the god Maru that accompanied us, and that it was by his power (mana) and the tapu of our tohunga that their braves were killed by the thunder of that god Maru. Then the whole $p a$ would feel dispirited (wiwi) and stand without sense, so that we had only to assault the $p a$ without any defence from the people.

'In this manner', White was told, the tauā 'passed through the Taranaki and Whanganui districts ... and beyond to Otaki, killing as we went ... we proceeded on to Porirua and Kapiti ... eating of those whom we conquered, until we arrived at Te Whanganui-a-Tara (Port Nicholson)'. There is evidence to suggest that this Māori source of White's may have been composed of more than one informant, but this is no reason to disbelieve its general veracity. The introduction of muskets to Māori warfare gave musket-armed Māori a significant advantage over their musketless enemies. ${ }^{21}$

\footnotetext{
${ }^{21}$ S.P. Smith, Maori Wars, pp.105-107, italics in original; Kendrick Smithyman, 'Making History: John White and S. Percy Smith at Work', JPS, 88:4, 1979, pp.375-413; Belich, Making Peoples, pp.2425 \& 159-160; Ballara, Taua, pp.20-21 \& 38-39; see also: Ann R. Parsonson, 'The Expansion of a Competitive Society: a Study in Nineteenth-Century Maori Social History', NZJH, 14:1, 1980, p.54
} 
When Hongi returned from England and Port Jackson with some 300 muskets in 1821 he began an arms race which was to have a massive impact on inter-iwi warfare. As Hongi used his arms advantage against traditional enemies, other iwi scrambled to acquire muskets - both in order to defend themselves against Ngāpuhi and in the hope of emulating Ngāpuhi success. Thus began the Musket Wars. ${ }^{22}$

Belich has identified the Musket Wars as the largest conflict ever fought in New Zealand: most iwi were involved and perhaps 20,000 Māori were killed. ${ }^{23}$ While the problems with the label 'Musket Wars' identified by Ballara are here acknowledged, the term is used because, as Ballara herself notes, while the introduction of muskets did not fundamentally change take, the reasons for Māori warfare, they did change the scope and scale of the conflicts, occasioning greater deaths and more dislocation. ${ }^{24}$ Muskets also changed the methods of Māori warfare: both means of attack and defence were modified in the wake of the introduction of muskets to Māori society. The 'Musket Wars' involved tauā then, but to label them 'Taua' is to risk confusing them with tauā outside the 1820s and 1830s. Thus the label 'Musket Wars' is here used to identify the period in which Māori inter-iwi warfare drastically increased in intensity and range, occasioned by an escalating in-

22 Clarke, journal, 22 June 1826, qMS-0465, ATL; Yate, Account, p.119; Wilson, From Hongi, pp.24-25; Rogers, Te Wiremu, p.50; Sinclair, Origins, pp.14-15; Sinclair, History of New Zealand, pp.41-42; Belich, Making Peoples, pp.156-164; cf. Ballara, Taua, pp.31-33

${ }^{23}$ Belich, Making Peoples, pp.156-164

${ }^{24}$ See for example: Clarke to col. sec., 17 October 1843, BPP, ii:pp.356-359; cf. S.P. Smith, Maori Wars, pp.16-19 
troduction of muskets to Māori warfare (c.1818), and ended with a saturation of muskets (c.1833)..$^{25}$

In examining how successful the evangelical campaign to suppress Māori violence was during this period, here it is argued that the Musket Wars came to an end when all iwi had roughly equivalent access to firearms, thus a saturation of muskets removed the advantage in which the origins of the wars lay. In the same way that an uneven supply of firearms instigated the conflicts, however, an uneven distribution of peace would have further encouraged warfare - if one iwi declared peaceful intentions before their neighbours, they then became vulnerable to tauā. While preaching against violence Clarke was told by attending Māori 'that the stronger always took advantage of the weaker'. He noted: Māori 'can never advance far in civilization while they are daily exposed without redress to the revenges of their stronger neighbour' ${ }^{26}$ The intervention of missionaries played a central role in a more even distribution of peace, though it is vital to note their successful mediations were requested by Māori. Evangelical importance has on the one hand been much inflated both by the evangelicals themselves, and by subsequent commentators who believed the missionaries' hyperbolic claims. Conversely, missionary intervention has been dismissed as unimportant or irrelevant by other critics. ${ }^{27}$ The evangelical suppression of Māori violence

\footnotetext{
${ }^{25}$ Belich further suggests that 'Potato Wars' might be a more accurate identifier than 'Musket Wars' as the integration of the successful large-scale cultivation of potatoes allowed Māori more time and energy to devote to warfare; Belich, Making Peoples, pp.159 \& 164; Ballara, Taua, pp.11-35

${ }^{26}$ Clarke, journal, 16 October 1825, qMS-0465, ATL

27 Wright, New Zealand, pp.141-183; Owens, 'Christianity and the Maoris', pp.18-40; Binney, 'Christianity and the Maoris', pp.143-165; John Owens, 'Religious Disputation at Whangaroa, 1823-7', JPS, 79:3, 1970, pp.288-304; Binney, Legacy of Guilt, passim; Robin Fisher, 'Henry Williams' Leadership of the CMS Mission to New Zealand', NZJH, 9:2, 1975, pp.142-153; K.R. Howe, 'The Maori Response to Christianity in the Thames-Waikato Area, 1833-1840', NZJH, 7:1, 1973, pp.28-46; Wilson, From Hongi, pp.92-123; Wilson, Kororareka, p.45; Belich, Making Peoples, pp.164-169; Ballara, 'Role of Warfare', pp.501-503; O’Malley, pp.162-169
} 
was effective, though European involvement relied heavily on Māori actively seeking their assistance, which was prompted by the saturation of muskets.

For evangelical missionaries who arrived in New Zealand in the first half of the nineteenth century, the suppression of Māori violence was imperative in achieving their goal of 'civilising' and Christianising Māori. In his CMS instructions, delivered on 6 August 1822, Henry Williams was warned of: '[ $t$ ]he eagerness of the Natives for fire-arms and ammunition, the manner in which these have been obtained, [and] the devastation and bloodshed which have followed' ${ }^{28}$ In the 1821 Missionary Register it was announced that the Māori ‘warlike disposition ... creates difficulties, which can only be overcome by the Blessing of God on patient exertions' ${ }^{29}$ Clarke optimistically declared in 1826: 'the Lord will override the cruelty of the New Zealanders'. ${ }^{30} \mathrm{Tu}-$ matauenga was to be usurped. While the missionaries had spoken against violence from their very arrival in 1814, it was not until the death of Hongi Hika in 1828 that they began to experience marked success in mediating between quarrelling Māori. ${ }^{31}$

Although prior to 1828 many Māori had expressed to the missionaries their desire for non-violent conflict resolution, and, the evangelicals claimed, requested British intervention to achieve this, Māori required that an end to violence be achieved without a loss of mana, which initially retarded missionary peacemaking efforts. As Māori interest in Christianity increased and

\footnotetext{
28 'Instructions of the Committee of the Church Missionary Society, delivered August 6, 1822, to the Rev. Henry Williams, proceeding as a missionary to New Zealand: with Mr. Williams's reply and an address by the Rev. Edward Garrard Marsh', v.081, HL

${ }^{29}$ Missionary Register, London:1821, p.79

${ }^{30}$ Clarke, journal, 22 June 1826, qMS-0465, ATL

${ }^{31}$ Report from the Select Committee on Aborigines, i:p.192; William Williams, Christianity Among the New Zealanders, London:1868, pp.89-112; Yate, Account, p.119; Rogers, Te Wiremu, passim, esp. pp.155-156; Ward, Show of Justice, pp.14-15; Hill, Policing the Colonial Frontier, i:p.50; Binney, Legacy of Guilt, pp.88-89 \& 89n; Belich, Making Peoples, pp.167-168; Wright, New Zealand, pp.43 \& 154; O’Malley, p.82
} 
the missionaries themselves began to acquire significant mana, however, they began to be able to assist in negotiating peace. As CMS missionary Alfred Nesbit Brown observed of the missionary-influenced resolution to the so-called Girls' War in 1830: 'pride would have prevented either party making peace, but neither were ashamed of doing it while the Missionaries were advocated for it and parties to it'. ${ }^{32}$

In March 1830 Henry Williams and his brother William, with Samuel Marsden, managed to assist in securing peace during the Girls' War - a dispute between rival Ngāpuhi hapū which had resulted in up to seventy casualties. $^{33}$ Early on in the peace negotiations, Henry Williams noted that the Māori involved 'acknowledged the correctness of our argument with them, and that they were urged to this madness by Satan'. ${ }^{34}$ Three days later he and Marsden, who had recently arrived in the Bay of Islands on his sixth New Zealand visit, together attempted to facilitate peace. Marsden observed that Williams 'entered upon the subject of our mission, stated unto them the evils of war, and more particularly of a civil war, in which they were engaged'. The evangelicals 'laboured to impress upon them that they were not fighting against a foreign nation but killing each other, and even some of their dearest friends'.

Having 'heard all we had to say with great attention', the gathered Māori reportedly told the evangelicals that the conflict was entirely the fault of the

\footnotetext{
32 A.N. Brown, journal, 18 March 1830, micro-MS-0030:reel 2, ATL

33 H. Williams, 1-24 March 1830, Early Journals, pp.155-160; Marsden, 6-21 March 1830, Letters and Journals, pp.451-470; Marsden to E. Bickersteth, 13 March 1830, HRNZ, i:pp.702-703; Brown, journal, 5-20 March 1830, micro-MS-0030:reel 2, ATL; Yate, Account, pp.118-119; Report from the Select Committee on Aborigines, i:pp.190-191; Rogers, Te Wiremu, pp.86-87; S.P. Smith, Maori Wars, pp.422-426; Hill, Policing the Colonial Frontier, i:pp.53-54; Wilson, From Hongi, pp.96-103; Wilson, Kororareka, pp.61 \& 83; Jocelyn Chisholm, Brind of the Bay of Islands: Some Readings and Notes of Thirty Years in the Life of a Whaling Captain, Wellington:1979, pp.34-41; Wright, New Zealand, pp.154-155; Adams, Fatal Necessity, pp.22 \& 38-39; Ballara, Taua, pp.201-204; Morton, p.71

34 H. Williams, 6 March 1830, Early Journals, pp.156-157
} 
whaler Captain Brind, that they 'were desirous to have the difference settled', and that they wished the missionaries to use their influence to effect peace. Williams added: '[e]very attention was paid to what we had to say and ... [t] he universal word was peace'. The following Sunday Marsden confidently asserted: '[t]he time will come when human sacrifices and cannibalism shall be annihilated in New Zealand by the pure, mild, and heavenly influence of the Gospel of our blessed Lord and Saviour.'35

On Monday Marsden pleaded with the assembled rangatira to stop internecine violence. He announced: 'that to kill one another was the greatest cruelty as well as folly; that they ought to save every New Zealander's life they could for the protection of themselves and their country; that the time might come when a foreign enemy would visit them, and that, when they wanted protection, they would have no men to protect them'. Such a time is examined in chapter six. Meanwhile, Marsden reported that the rangatira listened 'with great attention and admitted the justice of our observations', which 'seemed to strike them very forcibly'. Those assembled, he further noted, again pressed the missionaries to make peace. Two days later the missionaries presided over a hui (meeting) at which peace was arranged. The meeting concluded with a large haka (war dance), after which the evangelicals 'took our departure from these wild and savage scenes with much satisfaction, as we had obtained the object we had been labouring for' ${ }^{36}$

In his Account of New Zealand, Yate narrated an earlier occasion in which the CMS missionaries had intervened to prevent warfare between Ngāpuhi and Te Rarawa of the northern Hokianga in 1828. He later told a British parlia-

\footnotetext{
35 Marsden, 9 \& 14 March 1830, Letters and Journals, pp.460-461 \& 464; H. Williams, 9 March 1830, Early Journals, p.158

${ }^{36}$ Marsden, 15 \& 17 March 1830, Letters and Journals, pp.466-468; H. Williams, 17 March 1830, Early Journals, p.159
} 
mentary select committee that the 'battle of Hokianga' was to involve 2000 toa on each side. 'A few days before the different parties began to move to the scene of action', Yate wrote in his Account, 'it was suggested, by some of the peaceably-inclined and most influential chiefs, that there was one, and only one, way of making peace, without shedding blood - that they could not make peace themselves, but that the Missionaries might interfere, and place themselves in the breach, and propose terms'. He told the select committee that this was the 'first instance' in which 'the missionaries exercised their influence in making peace between contending tribes'. There had been only a few outnumbered rangatira who sought peace, one of whom said '[ $t$ ]here are these missionaries that have been talking to us for 15 years about peace, let us see what they can do'. 'As this opinion prevailed, that peace might be effected by our interference', Yate further wrote, 'a regular and formal application was made to the body of Missionaries, to accompany the army, and to use all the influence which they possessed, to prevent them from firing upon each other, and to secure a lasting peace between them', after which the missionaries effected peace primarily through Ngāpuhi rangatira Tāreha.

The select committee further asked Yate what 'sort of arguments' the evangelicals had used to persuade Tāreha. He replied that the missionaries had first reminded him that this conflict would result in 'lessening their own numbers' at a time when they could expect a tauā from the south. They then pleaded that this internecine violence was 'evil ... in the sight of that God whom we came to make known'. When these arguments appeared to have failed, as a last resort Henry Williams reminded Tāreha, whom Yate described as an 'enormously large man', 'you are a very big man, and no mus- 
ket-ball can pass by you'. ${ }^{37}$ The evangelicals then oversaw a peace hui 'which, to the joy of all, terminated most happily'. ${ }^{38}$

As Marsden and the brothers Williams later exclaimed in seeking peace during the Girls' War, at the battle of Hokianga Māori were explicitly told that internecine violence was 'evil'. Again as with the Girls' War, Yate's account of the 1828 peacemaking makes it clear that their interference was desired and requested by Māori. ${ }^{39}$ Had evangelical intervention not been wanted, as was generally the case prior to 1828 , the missionaries would not have been successful in preventing warfare.

As peace was adopted in the north, evangelical efforts - largely through Māori agency - began to produce results to the southward. Influenced by the missionaries' teachings, by 1830 Ngāpuhi had begun allowing slaves captured by earlier tauā to return to their various hapū. These captives had been allowed to attend mission schools and church while enslaved, and upon their release many took word of the missionaries back to their hapu and iwi. ${ }^{40}$ Along with the doctrines of Christianity, including that of peace, freed slaves spread word of the missionaries' role in securing reconciliation between rival iwi. Thus, as had been the case in the north, iwi to the south, who also saw their initial advantage overcome by the saturation of muskets, began requesting missionaries to mediate peace.

${ }^{37}$ Clarke (junior) recalled Tāreha was 'the hugest man I ever saw', while Richard Taylor wrote that Tāreha was 'the largest specimen of the savage, being nearly seven feet high, and stout in proportion ... [who] when seated, appeared like a huge mass of flesh; Clarke (junior), Notes, p.17; Richard Taylor, Te Ika a Maui, or New Zealand and its Inhabitants, London:1855, p.316

${ }^{38}$ Yate, Account, pp.115-118, emphasis in original; Report from the Select Committee on Aborigines, i:pp.189-190; H. Williams, 15-24 March 1828, Early Journals, pp.111-117; W. Williams, Christianity Among the New Zealanders, pp.105-114; Missionary Register, London:1828, pp.466-469; Binney, Legacy of Guilt, p.89n

39 cf. Wright, New Zealand, pp.154-155

40 Clarke (junior), Notes, p.28, Belich, Making Peoples, pp.167-168; Wright, New Zealand, pp.157162 \& 182; cf. Rogers, Te Wiremu, pp.20-21 \& 156 
While visiting Hauraki in early-1834, Yate was told by one rangatira that he was 'mad for Missionaries'. He declared that Waikato iwi wished to cease fighting, but that they could not end warfare until missionaries were present. Missionaries would, Yate was told, be able to 'break in two our clubs - to blunt the points of our spears - to draw the lead from our muskets and to make ... this tribe and that tribe love one another and sit as brothers and friends'. ${ }^{41}$ When Yate was later asked by the select committee '[w] reception have the missionaries met with in general', he replied 'the kindest possible reception' has been afforded since 1828. The missionaries have been 'received with open arms by every one', Yate continued, adding that iwi far from the mission stations at the Bay of Islands heard 'that peace had been established by us between hostile tribes in that district', and 'very frequently sent messengers ... to request us to form stations in the midst of them, primarily with the desire of our making peace between hostile tribes in their neighbourhood'. ${ }^{42}$

Missionary intervention contributed, therefore, to the end of the Musket Wars - a successful suppression of Māori violence. Evangelical contribution was, however, requested by Māori, whose appeal for peacemaking was related to the saturation of firearms, which was the leading cause of the end of the wars. When 'many an old tattooed warrior came forward and begged a book' from Clarke, 'saying he had long fought his enemies with musket and ball but now he would only fight with his book that should be his only weapon of defence', they were articulating the importance of both missionary mediation and an even adoption of peace among Māori. ${ }^{43}$

\footnotetext{
${ }^{41}$ Yate, journal, 3-4 January 1834, MS-copy-micro-0453, ATL

42 Report from the Select Committee on Aborigines, i:p.189

${ }^{43}$ Clarke to CMS secs., 20 January 1840, qMS-0464, ATL
} 
Missionary endeavour in peacemaking after the death of Hongi was not, however, universally successful. Ngāti Porou rangatira Piripi Raumata-aKura, who had been enslaved by Ngāpuhi during which time he was influenced by Christianity, swore revenge upon his evangelical-influenced release from slavery. On the eve of an attack seeking utu for his enslavement, in 1837 the former mōkai (slave) spoke to this gathered toa on proposed new rules of warfare.

Cast aside, indeed leave off the Māori gods, that we may have the one God for us ... If a man is killed as a result of your fire or your attack, neither cook nor eat him. Take nothing from the corpse, whether it be a gun, a cartridge belt, clothing, a patu or anything else ... take nothing away but let them recover their dead, lest you be cursed by God. ${ }^{4}$

Taumata-a-Kura, who went into battle with his musket in one hand and a Bible in the other, envisaged a more 'civilised' and Christian mode of warfare, fought with muskets, Christian prayer, assistance for the wounded, and recovery of the dead; without cannibalism, theft, or fighting on the Sabbath. ${ }^{45}$ 'Civilised' warfare was a partial success for evangelicals; having Māori cease warfare altogether was the ultimate goal.

Much to their eventual regret, the missionaries sometimes misunderstood Māori hunger for the Bible. A recent innovation in European weaponry, the prepared cartridge accompanied the introduction of muskets to Māori. This development - a paper tube packed with ball or shot and gunpowder made loading muskets much faster. ${ }^{46}$ Māori soon learned to make their own cartridges from any paper they could get, which during the 1820s and 1830s consisted mostly of religious texts printed by the missionaries. When Pākehā

\footnotetext{
44 Mohi Tūrei, 'He Korero Tawhito', Te Pīpīwharauroa, May 1910, pp.8-9, translated from te reo Māori by Monty Soutar, 'Ngāti Porou Leadership - Rāpata Wahawaha and the Politics of Conflict', PhD thesis, Massey University:2000, p.108

${ }^{45}$ Soutar, 'Ngāti Porou Leadership', pp.97-110; Wright, New Zealand, pp.176-177

46 Bentley, 'Tribal Guns, Tribal Gunners', p.46
} 
rambler John Boultbee confronted Kikoro about a stolen Bible, the interrogated Māori confessed he had taken it, but maintained that 'he did not know what book it was, and all he wanted it for was to make cartridges with' ${ }^{47}$ On the whole, however, Māori engagement with the Bible was genuine.

Māori interest in Christianity, and in particular Māori hunger for literacy which engagement with the religion brought, should not be underestimated. ${ }^{48}$ When, at Rotorua, '[o]ne young man began to ask the meaning of the letters', Henry Williams 'wrote them down for him, and in half an hour he knew them all, and was teaching several outside' ${ }^{49}$ Yate insisted that the 1800 copies of a 250-page book containing te reo Māori translations of a number of biblical passages, which he brought from New South Wales in August 1833, was: 'the most valuable cargo that ever reached the shores of New Zealand'.50 Brown was told by a Tüwharetoa rangatira that he had prevented Dr. Dieffenbach and Captain Symonds climbing Tongariro because of tapu. Although the explorers had offered gold, the rangatira told the missionary that his people had been insistent. However, 'had they brought some Testaments', the rangatira admitted, 'we would have consented to their going up the mountain'. Brown was told to tell the explorers when he next saw them 'if they return in the summer, and bring Testaments with them, the tapu shall be removed from the mountain'.$^{51}$

\footnotetext{
47 Boultbee, p.78; Wright, New Zealand, p.176; William Colenso, Fifty Years Ago in New Zealand. A Commemoration: a Jubilee Paper: a Retrospect: a Plain and True Story, Napier:1888, p.42; A.G. Bagnall and G.C. Petersen, William Colenso: Printer, Missionary, Botanist, Explorer, Politician, His Life and Journeys, Wellington:1948, p.61; Carleton, i:p.214; Markham, p.32

48 Wright, New Zealand, pp.52-53 \& 174-177; Marsden, 28 March 1830, Letters and Journals, p.474; Owens, 'Christianity and the Maoris', pp.18-40; C.J. Parr, 'A Missionary Library: Printed Attempts to Instruct the Maori, 1815-1845', JPS, 70:4, 1961, pp.429-450; D.F. McKenzie, Oral Culture, Literacy \& Print in Early New Zealand: the Treaty of Waitangi, Wellington:1985, passim

49 H. Williams, 29 October 1831, Early Journals, pp.198-199

50 Yate, Account, pp.231-232; see also: H. Williams to Marsh, 13 August 1833, cited in Carleton, i:p.138

51 Brown cited in Dandeson Coates, The New Zealanders and their Lands: the Report of the Select Committee of the House of Commons, on New Zealand, Considered in a Letter to Lord Stanley, London:1844, p.27
} 
Evangelicals themselves acknowledged the importance of the saturation of muskets in the end of the Musket Wars. In mid-1826 Clarke lamented: [a]s trading for muskets is principley confined to the Bay of Islanders, it plunges them, into an unjust war with every part of the [North] Island, whose inhabitants are unable to oppose their destructive intentions'. '[M]uskets have', he concluded, 'been the means of the extinction of many tribes; whereas, when fought with their own weapons, the loss of a few decided the war'. ${ }^{52}$ In response to having pointed out to him 'scenes of the ravages committed by the Ngapuhi' on a voyage down the east coast from the Bay of Islands to the Mahia peninsula in 1834, William Williams observed: 'the day I trust is now arrived when wars and rumours of wars shall cease in New Zealand'. 'Indeed', he continued, 'we may anticipate a very speedy termination of these evils'. At the time which is retrospectively associated with the end of the Musket Wars, Williams anticipated the conflicts were at an end because: '[t]he distribution of firearms, which is now become general, deprives in a great measure the strong of their ability to oppress the weak'. ${ }^{53}$

By the mid-1830s some missionaries were even advocating the widespread distribution of muskets to all Māori as a way of reducing Māori violence. In reference to Europeans supplying Māori with arms and gunpowder, Yate told the select committee 'that is done by every ship, and that now cannot be' objected to. '[S]o many muskets and so much powder has been introduced, that it would be well for every man to have his musket', he continued. '[T]hey would then be equally armed, and there would be less aggression' ${ }^{54}$ Whereas formerly the evangelicals had been induced to partake in arming

\footnotetext{
52 Clarke, journal, 22 June 1826, qMS-0465, ATL

53 William Williams, journal, 15 January 1834, qMS-2249, ATL, see also: William Williams and Jane Williams, The Turanga Journals, 1840-1850: Letters and Journals of William and Jane Williams, Missionaries to Poverty Bay, Frances Porter (ed.), Wellington:1974, p.57

${ }^{54}$ Report from the Select Committee on Aborigines, i:p.198
} 
Māori through their dependency on Māori for trade for their very survival, and had then lamented the effects of this on Māori violence, they eventually recognised that it was the uneven distribution of firearms which so exacerbated the scale of Māori violence, the devastating effects of which had led them to believe that equally arming all Māori could actually suppress Māori violence.

Henry Williams' son-in-law-cum-biographer Hugh Carleton believed that Williams himself had brought an end to the Musket Wars. 'War does not wear itself out in New Zealand; on the contrary, it spreads like fire, so long as there is stuff to consume', he wrote. 'The inexorable law of blood for "blood for blood" keeps on multiplying cause for vengeance, which only extermination can fore-close.' 'Nevertheless', Carleton concluded, 'after a series of wars, which are computed to have cost over sixty thousand lives, Henry Williams established his name as "the peace-maker" over the face of the country. ${ }^{55}$

Elder asserted that Marsden and his missionaries 'saved the Maori race from itself', as through their influence 'the internecine warfare to which all the energies of the chiefs had formerly been directed was fast becoming an unhappy memory'. ${ }^{56}$ Henry Williams' second biographer, Lawrence M. Rogers, exaggerated when he claimed Williams 'had become the acknowledged umpire' in inter-iwi and Māori-Pākehā disputes, but the missionary was sometimes an acknowledged umpire - $a$ peace-maker, not the peace-maker. ${ }^{57}$

\footnotetext{
55 cf. '[e]ventually the war ran itself out', Wright, New Zealand, p.45; the figure of 60,000 deaths has been revised to c.20,000; Carleton, i:pp:244-245; Belich, Making Peoples, p.157

${ }^{56}$ Elder (ed.), Letters and Journals, p.512

${ }^{57}$ Rogers, Te Wiremu, p.136
} 
At the close of the Musket Wars Clarke reported on the progress of the mission to his London supervisors.

The natives in connection with Miss. influence and instruction, have almost lost their ferocious appearance, and instead of seeing them rushing about with their muskets and spears, to revenge every little insult among each other, we not unfrequently see the tattooed old warrior coming from a distance of three, or four, or more miles, and with the greatest simplicity ask how best to settle real insults and lapses which they sustain from a more unprincipled neighbour. ${ }^{58}$

It is important not to overstate the role played by the missionaries in the conclusion of the Musket Wars; although it is also vital to remember Christianity and missionary mediation did play a significant part. Missionary intervention and Māori engagement with Christianity did assist in ending the Musket Wars, though the effects of evangelism were by no means the sole factor in the conclusion of the conflicts. It is no coincidence that the Musket Wars ended about 1833, when all iwi had roughly equal access to muskets, thus annulling the advantage the weapons had provided. ${ }^{59}$ The saturation of muskets allowed for successful missionary mediation. Although necessitated by a widespread diffusion of arms, evangelical-assisted peace was still vital to the end of the Musket Wars. Once rival iwi saw neither had the advantage muskets once provided, they began to desire peace. Like the uneven distribution of muskets which had encouraged the wars, an irregular adoption of peace necessitated a loss of mana and a vulnerability to enemies Māori could not accept. Thus, incorporating traditional Māori peacemaking techniques, ${ }^{60}$ the missionaries - who had been preaching peace since their

\footnotetext{
58 Clarke to CMS secs., 29 January 1834, qMS-0463, ATL

59 Belich, New Zealand Wars, p.20; Belich, Making Peoples, pp.167-168; Robert FitzRoy, Remarks on New Zealand, in February 1846, London:1846, pp.43-44; Polack's evidence in 'Report from the Select Committee of the House of Lords, Appointed to Inquire into ... New Zealand', August 1838, BPP, i:pp.85-86 \& 92; Wright, New Zealand, pp.83-84; Urlich, 'Introduction and Diffusion of Firearms', pp.399-410; Urlich, 'Migrations of the North Island Maoris', pp.27-29 \& 33; Vayda, 'Maoris and Muskets', pp.580-581; Ballara, 'Role of Warfare', p.501; Ballara, Taua, pp.436-443

${ }^{60}$ Vayda, Maori Warfare, pp.119-124
} 
first arrival - were asked to mediate; a method which ensured mana was maintained on both sides.

As missionary peacemaking efforts began to succeed, the evangelicals focused their efforts towards promoting British intervention in New Zealand, which they claimed Māori themselves desired. Upon returning from England in 1821, Ngāpuhi rangatira Waikato had accompanied Hongi on a raid southward using their newly acquired muskets. Waikato, who had no qualms about threatening to kill the ship's cook when he refused to make the rangatira pancakes on account of violent seas during their return voyage from England, was so appalled at the mass destruction wrecked by the new weaponry that he 'determined never to go to war again'. In 1823 Waikato reportedly told Marsden that 'he wished the English would come and take possession of the country, as he was sure there would be no end to their public calamities until there was a power sufficient to prevent those evils of war'. Marsden further claimed he had heard 'many chiefs express the same wish' ${ }^{61}$

In 1824 Marsden wrote to CMS secretary Josiah Pratt suggesting that Māori desired British intervention in inter-iwi violence. 'The New Zealanders themselves are very sensible of the want of a protecting Government, and would rejoice if anything could be done to prevent the strong from crushing the weak.' 'The New Zealanders want a head', he continued, noting that Māori had informed him that 'no chief would be willing to give up his au-

\footnotetext{
61 Binney, Legacy of Guilt, p.79; Marsden, 4 September 1823, Letters and Journals, p.364; Nicholas' evidence in 'Report from the Select Committee of the House of Lords, Appointed to Inquire into ... New Zealand', August 1838, BPP, i:pp.10-11
} 
thority to another, and they could not agree amongst themself to nominate any one chief as king' ${ }^{62}$

Eight years later, in a spur of optimistic belief that Māori would accept a degree of British authority, James Busby was appointed British Resident in New Zealand. Busby's appointment was in part occasioned by an 1831 petition by Hokianga Ngāpuhi to King William IV for protection from both European misconduct and French invasion. The 1831 plea had been written at the encouragement of Yate. In response, Busby was ordered to undertake the immense task of not only resolving and further preventing EuropeanMāori conflicts and internecine disputes, but also of encouraging Māori 'towards a settled form of government, and ... some system of jurisprudence' ${ }^{63}$

Busby is a man to be commended for introducing French and Spanish vine cuttings to New Zealand - thereby aiding Marsden's prophecy that 'New Zealand will be the finest country in the world for wine' - if for nothing else. ${ }^{64}$ He arrived in the Bay of Islands as British Resident on 10 May 1833. His position was to be funded, at no cost to the British treasury, by the colony of New South Wales.

It soon became clear that Busby was unable to moderate the 'lawless' behaviour of either Pākehā or Māori. And with his request for finance to fund assistance in the form of Māori police rejected by New South Wales Governor

\footnotetext{
62 Marsden to Pratt, 4 June 1824, HRNZ, i:pp.627-629

63 Bourke to Busby, 13 April 1833, BPP, iii:pp.52-54; Ward, Show of Justice, p.24-25; Coates, New Zealanders, pp.10-11; Sinclair, Origins, p.27; Adams, Fatal Necessity, pp.74-102; Ian Wards, The Shadow of the Land: a Study of British Policy and Racial Conflict in New Zealand, 1832-1852, Wellington:1968, pp.7-11

64 Marsden conversely believed that 'there is little prospect that New Holland will become a wine country'; Marsden to Pratt, 24 February 1819, Letters and Journals, pp.230-232; Marsden, 25 September 1819, Letters and Journals, p.180; Robert FitzRoy, Narrative of the Surveying Voyages of His Majesty's Ships Adventure and Beagle [1839], 2 vols., New York:1966, ii:p.576
} 
Sir Richard Bourke, Busby became known to Māori as the 'Man-o-War without Guns', or the 'Watch-Dog without Teeth' ${ }^{65}$ Māori duly noted the British Resident's powerlessness to prevent them fighting on his residency grounds and his inability to even prevent them rowing his boat about the harbour against his wishes. Busby was, furthermore, robbed and shot at by a group of Māori in April 1834. ${ }^{66}$ Far from being able to prevent or resolve violence in New Zealand, Busby could not even protect himself. When Captain FitzRoy (later governor of New Zealand) visited the Bay of Islands with Darwin in 1835, he sympathised with Busby's 'anxiety to receive definite instructions, and substantial support'. The Beagle's captain described the British Resident as '[a]n isolated individual, not having even the authority of a magistrate, encircled by savages, and by a most troublesome class of his own countrymen'. ${ }^{67}$ Contemporary Charles Terry recalled that Busby was sent to the Bay of Islands 'as British Resident, but with very limited and impotent functions' ${ }^{68}$

As Busby's arrival coincided with the immediate wake of the Musket Wars, he was initially chiefly concerned with the suppression of Māori violence. ${ }^{69}$ Bourke had instructed the British Resident to provide 'official mediation [in] the intestine war between rival chiefs, or hostile tribes ... and their differences peaceably and permanently composed'. ${ }^{70}$ The reality of the situation,

65 Keith Newman, Bible \& Treaty: Missionaries among the Māori - a New Perspective, Auckland:2010, p.81; Judith Binney, 'Tuki's Universe', in Keith Sinclair (ed.), Tasman Relations: New Zealand and Australia, 1788-1988, Auckland:1987, pp.28-29; Wards, Shadow, p.9; T. Lindsay Buick, The Treaty of Waitangi: How New Zealand Became a British Colony [1914], third edition New Plymouth:1936, pp.16-18

${ }^{66}$ Ward, Show of Justice, p.25; Buick, Treaty of Waitangi, pp.104-105

67 FitzRoy, Narrative, ii:p.576; FitzRoy's evidence in 'Report from the Select Committee of the House of Lords, Appointed to Inquire into ... New Zealand', August 1838, BPP, i:pp.164-165; John Gribbin and Mary Gribbin, FitzRoy: the Remarkable Story of Darwin's Captain and the Invention of the Weather Forecast, London:2003, pp.172-176

${ }^{68}$ Charles Terry, New Zealand, Its Advantages and Prospects, as a British Colony, London:1842, p.6

69 Orange, Treaty of Waitangi, p.19

70 Bourke to Busby, 13 April 1833, BPP, iii:pp.52-54 
however, differed vastly from the governor's ideal. FitzRoy described Busby as 'holding the undefined office of British Resident', whose authority 'was absolutely nothing'. 'To whom then', he rhetorically enquired, 'were the daily squabbles of so mixed and turbulent a population, as that of the Bay of Islands and its vicinity, to be referred?' He believed that the missionaries were 'the only real, though not nominal, authority, in the place' ${ }^{71}$

In 1834, in an attempt to enact Bourke's demand for jurisprudence, Busby led an assembly of northern rangatira in selecting a national flag. The following year, thirty-five rangatira representing 'The United Tribes of New Zealand' signed a Declaration of Independence. ${ }^{72}$ Despite this development, in 1836 Yate told the select committee of Busby: '[h]e has no power, no authority; he has nothing more than the King's letter.' Yate recommended to the House of Commons that Busby at least be given 'magisterial authority, and something like a constabulary force'. He clarified, however, that this power should be given only over British subjects, not over Māori, who 'must be dealt with through the influence of the chiefs'. The missionary further asserted that Māori desired 'civilised government' in New Zealand. 'They are', he announced, 'continually applying to us to give them rules and regulations by which they should conduct themselves in their intercourse with Europeans, and with each other. ${ }^{73}$ Busby's appointment as British Resident and the subsequent Declaration of Independence had little effect on inter-iwi violence rangatira appealed to and abided by Pākehā law only when doing so suited their purposes. ${ }^{74}$

\footnotetext{
${ }^{71}$ FitzRoy, Narrative, ii:pp.590-591

72 Ward, Show of Justice, pp.24-25; Coates, New Zealanders, pp.11-12; A.H. McLintock, Crown Colony Government in New Zealand, Wellington:1958, pp.23-26; Wards, Shadow, pp.23-24; Buick, Treaty of Waitangi, pp.22-32; John O. Ross, 'Note: Busby and the Declaration of Independence', NZJH, 14:1, 1980, pp.83-89

${ }^{73}$ Report from the Select Committee on Aborigines, i:pp.192-198

74 Walker, pp.88-89; Ballara, 'Role of Warfare', p.503
} 
In July 1838 Clarke wrote to the CMS secretaries advising them that '[i]t has ever appeared to us [missionaries] that the only prospect of saving the $\mathrm{Na}$ tives is by the British Government taking them entirely under their protection' ${ }^{75}$ Beginning with their arrival in 1814, the missionaries had witnessed much Māori violence, and had often attempted to intervene to suppress such bloodshed with some success. By the late-1830s, however, in the wake of the Musket Wars the evangelicals felt that the establishment of British law, and the means of enforcing it, were required to further suppress Māori violence. In January 1838 the missionaries collectively recommended that the whole country be secured under the protection and guardian care of the British Government, for a number of years, with a Resident Governor and other Officers; with a military force, to support their authority and insure obedience to all laws which may be enacted' ${ }^{76}$ The Crown, for their part, began to seek the suppression of Māori violence because it saw such violence as an inhibitor to the 'redemption' of Māori and an impediment to the colonisation of New Zealand.

In early-1837 Busby had requested from Governor Bourke European soldiers for military intervention in an escalating Māori conflict in the Bay of Islands. Despite having rejected similar earlier requests, Bourke despatched HMS Rattlesnake. Commanded by Captain William Hobson, the frigate arrived in the Bay of Islands in May 1837. Upon assessing the situation, Hobson un-

\footnotetext{
75 Clarke to CMS secs., July 1838, cited in G.W. Shroff, 'George Clarke and the New Zealand Mission, 1824-1850', PhD thesis, University of Auckland:1967, p.266

76 Dandeson Coates, Documents Exhibiting the Views of the Church Missionary Society on the New Zealand Question, and Explanatory of the Present State of that Country, London:1839, p.44; Alan Ward, 'Law and Law-enforcement on the New Zealand Frontier, 1840-1893', NZJH, 5:2, 1971, p.128; Ward, Show of Justice, pp.27-28; Lachy Paterson, 'Government, Church and Māori Responses to Mākutu (Sorcery) in New Zealand in the Nineteenth and Early Twentieth Centuries', Cultural and Social History, 8:2, 2011, p.176
} 
dermined Busby's requests for assistance from New South Wales, noting 'I am aware the British Resident is not free from apprehension; but ... he stands alone in the opinion he has formed'. The Māori conflict which had so concerned Busby was resolved without the interference of Hobson and his crew, and they soon returned to Port Jackson. ${ }^{77}$ Hobson, however, was to return to New Zealand less than three years later, this time as lieutenantgovernor.

In accordance with Secretary of State for Colonies Lord Normanby's instructions, in January 1840 New South Wales Governor George Gipps issued three proclamations. Gipps proclaimed that Hobson was to be lieutenantgovernor over any territory in New Zealand over which he managed to acquire sovereignty; that the confines of the colony of New South Wales now included said acquired territory; and that private land purchase in New Zealand was to cease. ${ }^{78}$

In mid-August 1839 Normanby advised Hobson on his upcoming role as lieutenant-governor. The secretary of state for colonies informed Hobson that the Crown believed that in the wake of increasing European contact, Māori ‘welfare would ... be best promoted by the surrender to Her Majesty a right now so precarious, and little more than nominal, and persuaded that the benefits of British protection, and of laws administered by British judges, would far more than compensate for the sacrifice by the natives, of a national independence, which they are no longer able to maintain'. Hobson was further instructed to make it clear that Māori were being offered 'protection' from Europeans. The direction embodies the implication that the British

\footnotetext{
77 Hobson to Bourke, 8 August 1837; Busby to New South Wales col. sec., 16 June 1837; Busby to New South Wales col. sec., 13 July 1837, BPP, iii:pp.23-32; Orange, Treaty of Waitangi, p.24; Buick, Treaty of Waitangi, p.40

78 BPP, i:pp.138-147; BPP, iii:pp.37-45
} 
were not offering Māori 'protection' from, nor restriction on, intra-Māori violence.

Hobson was, however, further advised of 'other duties owing to the aborigines of New Zealand', which Normanby summed up 'in the comprehensive expression of promoting their civilization, - understanding by that term whatever relates to the religious, intellectual, and social advancement of mankind'. Hobson was told that until Māori

can be brought within the pale of civilized life, and trained to the adoption of its habits, they must be carefully defended in the observance of their own customs, so far as they are compatible with the universal maxims of humanity and morals. But the savage practices of human sacrifice, and of cannibalism, must be promptly and decisively interdicted. Such atrocities, under whatever plea of religion they may take place, are not to be tolerated in any part of the dominions of the British Crown. ${ }^{79}$

Hobson immediately replied to his instructions to 'beg the favour of further explanation '[i]n order to avoid any misunderstanding' respecting his duties, particularly requesting 'more explicit instructions on this important subject' of interdicting 'the savage practices of cannibalism and human sacrifice'. 'Shall I be authorized, after the failure of every other means, to repress these diabolical acts by force?', he asked. 'And what course am I to adopt to restrain the no less savage native wars, or to protect tribes who are oppressed (probably for becoming Christians) by their more powerful neighbours?'80

In an uncommon fit of bureaucratic efficiency, Normanby replied immediately. He observed: '[i]t is impossible for me to prescribe the course to be pursued for the prevention of cannibalism, human sacrifices, and warfare

\footnotetext{
${ }^{79}$ Normanby to Hobson, 14 August 1839, BPP, iii:pp.85-90; HRNZ, i:pp.730-739

${ }^{80}$ Hobson to under-secretary of the colonial department, August 1839, BPP, iii:pp.90-92; HRNZ, i:pp.750-753
} 
among the native Tribes. But I have no difficulty in stating that, if all the arts of persuasion and kindness should prove unavailing, practices so abhorrent from the first principles of morality, and so calamitous to those by whom they are pursued, should be repressed by authority, and, if necessary, by actual force, within any part of the Queen's dominions' ${ }^{81}$ The Crown was not beyond using violence to suppress violence. ${ }^{82}$

After a day-long hui discussing the document the previous day, on 6 February 1840 te Tiriti o Waitangi was signed by some forty northern rangatira and Lieutenant-Governor Hobson. Te tiriti was later taken around New Zealand and eventually signed by some 540 Māori. ${ }^{83}$ Only 39 Māori signed an English-language copy of the treaty. 501 Māori signed te reo Māori versions - hence the preference here for the label 'te Tiriti o Waitangi' ${ }^{84}$ Ron Crosby cites te tiriti as the final factor which brought the Musket Wars to an end..$^{85}$ While it is here argued that the Musket Wars ended before 1840, and that internecine Māori warfare continued after the signing of the treaty, te Tiriti o Waitangi did mark an increase in colonial official efforts to suppress Māori violence as New Zealand was incorporated into the British Empire.

Significantly, rangatira had not been invited to the Waitangi hui by the new kāwana (governor) Hobson, but by Busby, the former British Resident. ${ }^{86}$

\footnotetext{
81 Normanby to Hobson, 15 August 1839, BPP, iii:pp.92-93; HRNZ, i:pp.753-755

82 Ian Wards has discounted the myth, pervasive in New Zealand historiography until the late1960s, that colonial officials were prepared only to use 'moral suasion' in their attempts to conform Māori to their 'civilised', Christian, European ideal; Wards, Shadow, passim, esp. pp.30-31; cf. McLintock, pp.168-192

83 Terry, pp.19-27; FitzRoy, Remarks, pp.9-10; Orange, Treaty of Waitangi, p.260

84 R.M. Ross, 'Te Tiriti o Waitangi: Texts and Translations', NZJH, 6:2, 1972, p.136n

85 Ron Crosby, The Musket Wars: a History of Inter-Iwi Conflict, 1806-45, Auckland:1999, p.20

86 Ross, 'Te Tiriti o Waitangi', pp.130-132
} 
From the British perspective this may have been in order to take advantage of Busby's influence among Māori relative to that of the newly arrived Hobson. From a Māori perspective, however, that the invitation was from Busby and not Hobson likely influenced their developing perceptions of the lieutenant-governor's mana - of what a governor's duties and influences were, and what they were not; of what a governor was, and what one was not. This is extremely significant in light of the importance of the term 'kawanatanga' in te tiriti.

During the 5 February debates a number of rangatira spoke out against signing the treaty. Hobson reported that ' $[\mathrm{t}]$ wenty or thirty chiefs addressed the meeting, five or six of whom opposed me with great violence, and at one period with such effect and so cleverly, that I began to apprehend an unfavourable impression would be produced' ${ }^{87}$ During the Waitangi hui, kōrero (speeches) often began with rangatira objecting to the idea that they may be placed beneath the Queen or beneath a governor and voicing their fear that they would have their lands taken and be enslaved or killed. Some rangatira pointed across the Tasman Sea, to the British colonisation of New South Wales and Van Diemen's Land, as an example of what Māori might expect from the Crown. ${ }^{88}$ In speaking out against te tiriti, Kororāreka rangatira Rewa drew on his knowledge of New South Wales: '[s]end the man away; do not sign the paper; if you do, you will be reduced to the condition of slaves, and be obliged to break stones for the roads. Your land will be taken from you, and your dignity as chiefs will be destroyed' ${ }^{89}$

\footnotetext{
87 Hobson to Gipps, 5-6 February 1840, BPP, iii:pp.45-46

${ }^{88}$ Ward, Show of Justice, p.42; Carleton, ii:p.6; Orange, Treaty of Waitangi, pp.46-51 \& 61-64; Sinclair, Origins, p.17; Salmond, Two Worlds, pp.232-233; O’Malley, pp.44-45

89 Hobson to Gipps, 5 February 1840, BPP, iii:pp.45-47; Coates, New Zealanders, p.16; Sydney Herald, 21 February 1840, p.2; Felton Mathew, The Founding of New Zealand: the Journals of Felton Mathew, First Surveyor-General of New Zealand, and his Wife 1840-1847, J. Rutherford (ed.), Dunedin:1940, pp.36-37; Terry, pp.15-18; Orange, Treaty of Waitangi, p.47n; see also: Richard Taylor, journal, 5 \& 12 February 1840, qMS-1984, ATL
} 
The assurance of rangatiratanga, promised in article two of te tiriti, was vital in convincing Māori to sign. By contrast, the British asserted that article one of the treaty secured full sovereignty for the Crown. Henry Williams and his son Edward, who translated the treaty into te reo Māori, had offered the word 'kawanatanga' for sovereignty in the first article. Kāwanatanga, a neologism, came from the te reo Māori transliteration of governor, kāwana. Kāwanatanga, which had earlier been used in the 1835 Declaration of Independence, therefore meant 'governance', not full sovereignty in the British sense, for Māori. Māori identified this 'governance' with the recently arrived Hobson, or with various governors of New South Wales whom they had met or heard of. Kāwanatanga had also been used in the preamble of te tiriti as a translation of both 'sovereign authority' and 'civil government'. Māori signatories thus believed themselves to be signing over 'the complete governance of their lands', not complete sovereignty. Mana has been suggested as a more appropriate translation of sovereignty, but Māori were extremely unlikely to have signed over their mana - something the missionary translators well knew..$^{90}$

In the second article of te tiriti, Māori were promised tino rangatiratanga. Another neologism, rangatiratanga derives from the te reo Māori term ran-

90 George Clarke, Extracts from the Final Report of the Chief Protector of Aborigines in New Zealand, Auckland:1846, pp.7-8; Ross, 'Te Tiriti o Waitangi', pp.129-157; Orange, Treaty of Waitangi, passim, esp. pp.1, 10 \& 39-43; Binney, 'Tuki's Universe', p.30; Belich, New Zealand Wars, pp.20-21; Belich, Making Peoples, pp.193-197; James Belich, 'Review Article: Hobson's Choice', NZJH, 24:2, 1990, p.202; Paul Moon and Sabine Fenton, 'Bound into a Fateful Union: Henry Williams' Translation of the Treaty of Waitangi into Maori in February 1840', JPS, 111:1, 2002, pp.51-64; Adams, Fatal Necessity, p.164; J.M.R. Owens, 'New Zealand before Annexation', in Geoffrey W. Rice (ed.), The Oxford History of New Zealand: Second Edition, Auckland:1992, pp.51-52; Rachael Bell, "'Texts and Translations": Ruth Ross and the Treaty of Waitangi', NZJH, 43:1, 2009, pp.39-58; Ward, Show of Justice, pp.44-45; Alan Ward, 'Commentary: the Treaty and the Purchase of Maori Land', NZJH, 22:2, 1988, p.170; cf. Lyndsay Head, 'The Pursuit of Modernity in Maori Society: the Conceptual Bases of Citizenship in the Early Colonial Period', in Andrew Sharp and Paul McHugh (eds.), Histories of Power and Loss: Uses of the Past - a New Zealand Commentary, Wellington:2001, pp.103-108 
gatira, chief, and with the addition of the prefix tino and the suffix tanga signified 'full chieftainship'. Rangatiratanga, like mana, has also been suggested as a more appropriate translation of sovereignty, because rangatira and their mana were inseparable. ${ }^{11}$ Māori thus considered themselves to be signing over 'governance' of their lands but firmly believed themselves to be retaining 'full chieftainship', and therefore mana, over said lands.

The third article of te tiriti offered Māori the 'protection' of the Queen of England, as well as the rights and privileges of British subjects. However, that this necessitated Māori obedience to British law was not stressed, again as it would likely have affected Māori willingness to sign. ${ }^{92}$ That Māori submission to British law was not emphasised in te tiriti was to become a significant factor in post-1840 colonial attempts to suppress Māori violence.

At the Waitangi hui, a statement additional to the treaty was read out at the request of French Bishop Jean Baptiste François Pompallier. Concerned that Catholicism might be suppressed in the British colony forming before his eyes, Pompallier asked that a public assurance be made that 'free toleration' be guaranteed in 'matters of faith'. Hobson agreed. Henry Williams, furious at having to translate such an assurance of Catholic tolerance, then announced: '[t]he Governor says that the several faiths of England, of the Wesleyans, of Rome, and also the Maori custom, shall be alike protected by him'. This guarantee was repeated at signings of te tiriti around New Zealand. As Orange shows, this official promise of the protection of Māori custom was 'an inclusion arising from sectarian jealousy'. Guaranteeing to preserve tikanga contradicted both the evangelicals' aim of 'civilising' and

\footnotetext{
91 Ross, 'Te Tiriti o Waitangi', pp.141-143; Orange, Treaty of Waitangi, pp.39-43; Hill, Policing the Colonial Frontier, i:p.212; Richard S. Hill, 'Maori Police Personnel and the Rangatiratanga Discourse', in Barry Godfrey and Graeme Dunstall (eds.), Crime and Empire, 1840-1940: Criminal Justice in Local and Global Context, Devon:2005, p.175; Walker, pp.90-97; cf. Head, pp.103-108

92 Orange, Treaty of Waitangi, pp.42-43
} 
Christianising Māori, and the colonial official desire, voiced in Hobson's instructions, to suppress Māori customs 'abhorrent to the first principals of morality' ${ }^{93}$ Nevertheless, Māori were promised that upon signing te tiriti they would be allowed to maintain tikanga Māori, which included practices such as kaitangata, tauā, utu, muru, and other violent traditional customs considered 'uncivilised', unchristian, and unacceptable by Europeans. This guarantee was not upheld.

Masters of oratory, Māori debated the proposed treaty for an entire day prior to signing at Waitangi. During this hui a number of Europeans, including colonial officials and missionaries, spoke at length encouraging Māori to sign for a variety of reasons. These encouragements were repeated at later signings. Among those who circulated te tiriti seeking signatures on behalf of the Crown was Major Thomas Bunbury. On a visit to Otumoetai pā in the Bay of Plenty in May 1840, Bunbury reported to Hobson the response of a Ngāi Te Rangi rangatira to his being asked to sign. The man reminded him that Cook was the first European to visit his lands, and that Cook's monarch was 'Georgi'. So, he asked, 'who then was this Queen?' Bunbury explained that King George III 'had been dead some years and also his two sons Georgi and Williami, who had succeeded him on the throne, and that the present queen was the granddaughter of George'.

Seemingly satisfied with Queen Victoria's whakapapa (genealogy), the rangatira 'then averted to the wars of their tribes and chiefs, particularly with the natives of Vota Vua [Rotorua]'. Bunbury 'told him that one of the principal objects of my mission was to persuade all tribes at present at war with

\footnotetext{
93 ibid., pp.53 \& 89; Carleton, ii:pp.11-15; Rogers, Te Wiremu, pp.167-168; William Colenso, The Authentic and Genuine History of the Signing of the Treaty of Waitangi [1890], Christchurch:1971, pp.31-32; Philip Turner, 'The Politics of Neutrality: the Catholic Mission and the Maori 1838-1870', MA thesis, University of Auckland:1986, pp.87-106; Peter Low, 'Pompallier and the Treaty: a New Discussion', NZJH, 24:2, 1990, pp.190-199
} 
each other to accept the mediation of' the governor, and to abide his decision. 'If your nation is so fond of peace', the rangatira replied, 'why have they introduced into this country fire-arms and gunpowder?' Bunbury stated that 'the effects of this trade have been much deplored by the Queen's Government, who were anxious to mitigate its consequences, and to secure a regular form of government for this country', which, he asserted, 'could only be effected by giving the Queen the necessary powers, and it was for this purpose they were asked to sign the treaty'. The rangatira then asked the major, should he do as the governor asked and abstain from war with Te Arawa, would the governor send troops to protect his people? Bunbury replied that Hobson 'desired rather to mediate between them', and the chiefs then signed. ${ }^{94}$

An oral people in the process of rapidly becoming literate, Māori believed that the oral agreements and promises made prior to, during, and after te tiriti was signed were just as, if not more important and valid as the written text of te tiriti. Moreover, upon questioning words and concepts expressed in te tiriti, Māori were offered further explanation in the form of altered translations or further promises, which were not included in the written text. For the British, however, it was the written text which mattered. Moreover, whereas the vast majority of Māori signed te reo Māori versions of te tiriti, the Crown based its policies and actions on the English-language version of the document. ${ }^{95}$

94 Bunbury to Hobson, 5 May 1840, Thomas Bunbury, Reminiscences of a Veteran: Being Personal and Military Adventures in Portugal, Spain, France, Malta, New South Wales, Norfolk Island, New Zealand, Andaman Islands, and India, 3 vols., London:1861, iii:pp.93-98; Terry, p.23

95 Ross, 'Te Tiriti o Waitangi', pp.129-157; Orange, Treaty of Waitangi, pp.46-59; Belich, Making Peoples, pp.194-196 \& 200; Hickford, pp.101-102; J.M.R. Owens, The Mediator: a Life of Richard Taylor, 1805-1873, Wellington:2004, p.49 
As it had done in New South Wales with regard to Aborigines, debate about whether Māori were British subjects, subject to British law, arose in earlycolonial New Zealand. ${ }^{96}$ In October 1841, E.J. Wakefield, son of Edward Gibbon Wakefield, witnessed in Wellington a court session in which a rangatira named Pakewa was tried for stealing a blanket. The jury was informed, Wakefield reported, that 'the natives were in truth and in fact British subjects, and that they were to be treated in every respect as any of ourselves; and that they had the same right to the protection of the law, and must be held equally amenable for any breach of it'. Pakewa's defence, led by assigned counsel Dr. Evans, argued that 'by the Treaty of Waitangi all the rights of chieftainship were reserved to [Māori]; and that among those rights was that of administering justice among the inhabitants of their own tribe'.

When the trial resumed the following day, Evans withdrew his original appeal to the treaty because the blanket had been taken from a Pākehā shopkeeper. He argued, however, that Pakewa was not 'a native-born English subject; and the law had been laid down with great clearness to the effect that aliens by birth could only acquire the rights of natural-born subjects by an Act of Parliament'. 'As an alien', Pakewa's defence concluded, 'he was entitled to a jury composed of half of his own countrymen' and half of Europeans. The Crown Prosecutor countered that the defendant was a British subject: as 'soon as New Zealand became a British colony, all the natives became ipse facto British subjects'. The jury returned a verdict of guilty after retiring for only a few minutes, but recommended mercy because the prisoner was the first Māori to be tried under British law in the colony. Pakewa

\footnotetext{
96 see also: Clarke, 'Half-Yearly Report', 30 June 1843; Freeman to Clarke, 24 July 1843; Clarke to col. sec., 31 July $1843-B P P$, ii:pp.342-350
} 
was sentenced to seven days' hard labour. ${ }^{97}$ Unlike Aborigines, who were retrospectively declared to have been British subjects from 1788, Māori were assumed to be British subjects, subject to British law, from 1840.

Declaring Māori to be subject to British law proved problematic for colonial officials. Hobson soon foresaw the difficulties in applying British law to Māori, which in theory required the suppression of many Māori customs. On 15 October 1840 the governor wrote to the secretary of state for colonies: 'the Native population offer us but trifling interruption; yet their habits are so inveterately opposed to those of civilized life, and their practices so repugnant to the customs of Englishmen, that we can scarcely hope to preserve such harmony when settlers become more numerous' ${ }^{98}$ In order to govern Māori as British subjects, colonial officials were tasked with suppressing 'uncivilised' and 'unlawful' Māori violence.

Within his instructions pertaining to the establishment of British rule in New Zealand, Hobson had been directed to employ 'an officer expressly appointed to watch over the interests of the aborigines as their protector'. Among the 'first duties' Hobson was to inform his aboriginal protector of was the acquisition of Māori land, 'confined to such districts as the natives can alienate, without distress or serious inconvenience to themselves', for the Crown to resell to settlers. ${ }^{99}$ As noted above, Hobson immediately replied to his instructions begging further explanation. Observing that 'allusion is made to the Protector of Aborigines', he stated:

\footnotetext{
97 Wakefield, ii:pp.145-149, italics in original; New Zealand Gazette and Wellington Spectator, 9 October 1841, p.3; Ward, Show of Justice, pp.46-47; Clarke to col. sec. 31 July 1843, BPP, ii:pp.346350

98 Hobson to Stanley, 15 October 1840, BPP, iii:pp.235-236

99 Normanby to Hobson, 14 August 1839, BPP, iii:pp.85-90; HRNZ, i:pp.729-739
} 
[w]ere the functions of this officer confined to the protection of the natives from physical injury or injustice, there could not be two opinions on the subject of his duty. But in matters which relate to their general welfare, he and I, with equal zeal in their cause, may entertain very different ideas. I sincerely hope that the duties of this officer may be exactly defined, and that the Government may be secured from the effect of captious opposition. ${ }^{100}$

Rather than issuing fuller instructions, the secretary of state for colonies simply assured Hobson that the protector would be subordinate to the governor. ${ }^{101}$

The imprecise instructions regarding protection which had concerned the Port Phillip protectors also affected the New Zealand protectors. In writing to his newly appointed sub-protector of the western district in August 1844, the chief protector outlined his duties.

You will consider the varied exercise of our official duties as connected with and based upon the primary intention of H.M. Government in the formation of the Department with which you are connected, viz. to watch over the interests, to protect the persons and property, and advance the social and moral improvements of Her Majesty's Aboriginal Subjects.

Among other instructions, the chief protector further informed his subordinate he was to '[i]mpress on their mind the benefits arising from the establishment of a well organized Government amongst them, let them see the practical results of it', and to '[l]et them distinctly understand that wars and the practice of Cannibalism must cease. That if persisted in, such conduct will eventually be visited with severe punishment'. ${ }^{102}$ The following day he promised to send fuller instructions pertaining to the role shortly. He wrote

\footnotetext{
100 Hobson to under-secretary of the colonial department, August 1839, BPP, iii:pp.90-92; HRNZ, i:pp.751-753

101 Normanby to Hobson, 15 August 1839, BPP, iii:pp.92-93; HRNZ, i:pp.753-755

102 Clarke to McLean, 2 August 1844, MS-Papers-0032-0001, Object\#1016796, ATL
} 
again later in the month to explain he could 'say nothing until I see the Governor when I will write you fully'. ${ }^{103}$ 'I do not think', the chief protector wrote to the same sub-protector eight months later by way of fuller instructions, 'you can do better than pursue your own quiet course among the natives by settling their disputes among [themselves, and] among themselves and the Pakehas' ${ }^{104}$

In January 1841 Lord Russell instructed Hobson that between fifteen and twenty per cent of colonial revenue raised from land sales in New Zealand 'must be carried to the credit of the department of the protector of aborigines'. The Protectorate funds were to be used 'for promoting the health, civilization, education and spiritual care of the natives' ${ }^{105}$ This order should have secured the Protectorate a phenomenal amount of money. Much to Surveyor-General Felton Mathew's surprise, allotments in the newly surveyed township of Auckland were selling for as much as those 'in the immediate vicinity of London or Liverpool'. ${ }^{106}$ Meanwhile, '[t]he Government congratulated themselves on the large amount to be received into the treasury' $^{\prime 107}$ Russell's instructions were ignored, however, and the Protectorate suffered for want of funds. The British Crown was concerned with the business of colonisation, and the incompatibility between the land, labour, and resources of indigenous peoples which it sought on the one hand, and the future well-being of indigenous peoples on the other, was a difficulty colonial administrators struggled to alleviate.

103 ibid., 3 \& 19 August 1844, MS-Papers-0032-0215, Object\#1014172 \& Object\#1000201, ATL

104 ibid., 15 April 1845, MS-Papers-0032-0215, Object\#1000506, ATL

105 Russell to Hobson, 28 January 1841, BPP, iii:pp.173-174

106 Mathew, pp.198-199; Terry, pp.129-159; J. Rutherford, Hone Heke's Rebellion: an Episode in the Establishment of British Rule in New Zealand, Auckland:1947, pp.20-21

107 Terry, p.136 
Carleton believed that the establishment of the Aboriginal Protectorate in New Zealand was exceptional: '[f]or it led to the impression that, in the opinion of the Government, protection was needed for men who were only too well able to protect themselves; touchy, suspicious, keen-witted in dealing; ready to resent the slightest grievance, and strong enough to drive the Pakeha into the sea, should it be left unredressed.' ${ }^{\prime 08}$ Carleton was confused as to the duties of the role of an Aboriginal Protectorate in New Zealand. A significant part of the duties of the office was the suppression of intra-Māori violence. As Peter Gibbons has shown, the second of the dual motives of the Protectorate, alongside the philanthropic desire to 'protect' Māori, was a desire to assert British sovereignty. ${ }^{109}$ To these can be added a third purpose: the means to alienate Māori land.

Upon arriving in New Zealand, Hobson consulted Henry Williams with regard to the appropriate choice for the position of protector of aborigines. Williams nominated George Clarke, he 'being the least swayed by fear of man, and having a sound judgement'.110 Hobson heeded Williams' advice and appointed Clarke chief protector of aborigines. Clarke resigned from the CMS. Charles Terry contemporaneously observed that it was 'perfectly impracticable, that the various numerous duties ... over such an extent of country, and so great a number of natives, can be performed by one person, with satisfaction to the Government, or with justice to the Aborigines' ${ }^{111}$ The colonial government agreed, soon realising that the task of 'protection' was too

108 Carleton, ii:p.18

109 Gibbons, p.108; cf. Carol Yeo, 'Ideals, Policy \& Practice: the New Zealand Protectorate of Aborigines 1840-1846', MA thesis, Massey University:2001, pp.15-16

110 H. Williams, 'Early Recollections', in Carleton, ii:p.20; Taylor, journal, 14 April 1840, qMS-1984, ATL; Clarke (junior), Notes, p.39; H. Williams to Clarke, 18 February 1840, qMS-0468, ATL; T. Lindsay Buick, New Zealand's First War, or the Rebellion of Hone Heke [1926], Christchurch:1976, pp.213-214

111 Terry, p.218 
great for one official, and the Protectorate office became a revolving door of names. ${ }^{112}$

Despite Hobson having been specifically instructed that the protectorate department was to 'be disconnected from the Mission', the appointment of Clarke, two of his sons, and sons of the missionaries Henry Williams, James Kemp, and Richard Davis, ensured that the aboriginal protectorate was very much a missionary-influenced evangelical endeavour. Clarke, for his part, saw his role as chief protector as a continuation of his mission work. ${ }^{113}$

The lieutenant-governor told his chief protector that he should act 'first, as Protector of the Native Race in the literal acceptation of those words', and, with the secretary of state for colonies' instructions in mind, 'secondly as a Commissioner for the purchase of such waste lands as the Natives may alienate without prejudice to their own interest and with manifest advantage to the country at large'. 'However incongruous these two offices may appear', Hobson concluded, 'I consider them in your hands to be perfectly reconcilable as I know you to be deeply interested in the welfare of the Native population, and at the same time fully impressed with the general interests of the community'.114

The 'alienation' of 'waste' Māori lands made up the majority of Clarke and his sub-protectors' work until the end of 1842. Up until late that year Clarke had repeatedly petitioned Hobson on the difficulties of trying to 'protect' Māori while simultaneously attempting to buy much of their land. Although

112 see: Gibbons, pp.19-26; Yeo, pp.21-32; Roger Evans, Truth and Obedience: the Life and Letters of George Clarke 1798-1875, Missionary, Protector of Aborigines, and Defender of the Treaty of Waitangi, Kerikeri:2004, pp.64-65

${ }_{113}$ Clarke to CMS secs., 25 April 1840, qMS-0464, ATL; Clarke, Final Report, pp.12-13; see also: Evans, Truth and Obedience, pp.174-175; Shroff, p.271

${ }^{114}$ Hobson, 'Instructions for George Clarke Esquire, Chief Protector of Aborigines', nd, qMS-0468, ATL 
land purchase was officially removed from the protectors' duties at the end of 1842 , 'this act of justice came too late', Clarke wrote, 'to prevent the evils which resulted from the false position in which, as land-agent for the Government, I had been placed'. ${ }^{115}$ Moreover, the protectors continued to remain involved in the Crown acquisition of Māori land well after this date. ${ }^{116}$ Clarke was even accused of accepting fees from settlers for securing land for them, although Keith Sinclair has deduced that 'he was probably not guilty'. ${ }^{117}$

Following the relief, at least officially, of their duty to acquire Māori land for the Crown, the protectors were able to focus their energies toward their other responsibilities, which included suppressing Māori violence. As the lieutenant-governor had earlier told his chief protector, he had been instructed 'to interdict promptly the savage practice of human sacrifice, cannibalism and native wars by the acts of persuasion and kindness if possible'. '[B]ut if these fail', Hobson continued, 'I am ordered to repress by actual force crimes so abhorrent to the first principles of morality and so calamitous to those by whom they are pursued' ${ }^{118}$

The protectors were commissioned justices of the peace. Moreover, at least one sub-protector, Edward Shortland, was appointed police magistrate, with powers to assist him in his role of suppressing both Māori-Pākehā and internecine Māori violence. ${ }^{119}$ The protectors were instructed: '[i]n your magisterial capacity, where natives are concerned, there are many minor offences or

\footnotetext{
115 Clarke, Final Report, p.5

116 see for example: McLean to Clarke, 17 December 1844 \& 6 January 1845, MS-Papers-0032-

0215, Object\#1015141 \& Object\#1015271, ATL

117 Sinclair, Origins, pp.29-32

118 Hobson, 'Instructions of George Clarke', nd, qMS-0468, ATL; see also: Normanby to Hobson, 14 August 1839, BPP, iii:pp.85-90; HRNZ, i:pp.729-739; Normanby to Hobson, 15 August 1839, BPP, iii:pp.92-93; HRNZ, i:pp.753-755

119 Hill, Policing the Colonial Frontier, i:pp.176-177
} 
disputes which you may compromise or adjust in accordance with their custom, which, if brought before a court of justice, and judged according to the strict and rigid interpretation of the law, might subject them to grievous punishments'. ${ }^{120}$ As had his Port Phillip counterpart, Clarke found these instructions too vague. He replied: 'the nature of these offences which may be compounded, are not described, and I am at a loss to conceive how such a simple principle can be carried out until native customs have been legalized, or an enactment made to meet the case'. ${ }^{121}$ With the possible exception of Governor FitzRoy's short-lived Native Exemption Ordinance of 1844, no such law was made, no such enactment passed. In theory Māori were, from 1840, subject to British law; in reality, however, in cases which involved only Māori, in the early years of the colony the protectors and other colonial officials could often do little to enforce British law.

Sub-Protector Clarke (junior) later concluded Māori had 'very stringent laws that were not at all unsuited to their condition', and noted 'they were far more conservative in observing them that we are in our modern changes of fashion or conviction'. Tikanga Māori was, the sub-protector reflected, 'the source of great trouble to us when we tried to supersede them by our own advanced civilisation'. 'Our only hope of keeping peace between the races', he added, 'was by gradually modifying their system until it should be merged with our principles of possession, and I am strongly of opinion, that nearly all our contention with the Maoris has arisen from our disregard of these fundamental considerations, or from the attempt to abolish them too suddenly, and with too high a hand.'122 Clarke (junior) was, however, writing with the benefit of hindsight following a period of prolonged BritishMāori warfare - the New Zealand Wars. During the early-1840s, the Crown,

\footnotetext{
${ }^{120}$ Clarke to col. sec., 31 July 1843, BPP, ii:pp.346-350

121 ibid.

122 Clarke (junior), Notes, pp.45-47
} 
through colonial administrators such as the protectors, attempted to suppress many Māori customs, especially those violent tikanga which they deemed 'uncivilised'.

In 1842 Ngāti Maru rangatira Taraia led a tauā against a Ngāi Te Rangi pā near Tauranga. The Ngāti Maru killed a number of Ngāi Te Rangi, captured about twelve women and children, and practised kaitangata. Ngāi Te Rangi, an iwi engaging with Christianity, were encouraged by the CMS missionary Brown to appeal to Governor Hobson for protection, which they did. At Hobson's instigation, Chief Protector Clarke informed Taraia that his actions had been an affront not only to Ngāi Te Rangi, but also to the colonial government. Taraia, who had refused to sign te Tiriti o Waitangi when it was brought to Hauraki, countered that the government had no right to interfere in internecine Māori disputes, and questioned why the governor was acting now, when he had ignored numerous similar previous incidents.

Clarke wrote to Hobson about the cannibalism undertaken by Ngāti Maru. The chief protector informed the governor that he had interviewed Taraia after he and his people had attacked Ngāi Te Rangi. Upon enquiring into 'whether or not it was true that the disgusting practice of cannibalism had been revived', Clarke had been told yes, 'two bodies had been eaten', to which the chief protector had 'told him in what abhorrence Europeans held such a practice, and that it was the determination of Her Majesty's Government to put a stop to it'. Taraia responded by declaring that 'it was a matter in which Natives alone were concerned, and he did not see what business the Governor had to interfere in it. Had he injured a European, it was a sub- 
ject for the Governor, but not this'. The colonial officials were further told: 'pork is the food for the Pakeha, human flesh for the Maori'. ${ }^{123}$

A correspondent for the New Zealand Gazette and Wellington Spectator observed in January 1843, with some exaggeration, that 'whatever may be their ideas of English Justice, [Māori] have, on all occasions, shewn a readiness to submit all matters in dispute between themselves and the white people to the decision of the English authority'. ${ }^{124}$ In internecine Māori disputes, however, Māori asserted that they had a right to continue their traditional practices without Pākehā interference. Taraia responded to Shortland's threat by writing to the kāwana on behalf of his toa 'to say that they had heard he was a fat man, and they hoped he would come to their Pa, as when cooked they thought he would make an excellent addition to their meal of potatoes' ${ }^{125}$

On this occasion, the chief protector managed to negotiate the release of the Ngāi Te Rangi prisoners and the promise of compensation from Taraia. The Ngāti Maru rangatira further offered to cease fighting altogether if the governor would send troops to protect his people from other iwi. Clarke and

\footnotetext{
123 J. White, The Ancient History of the Maori, His Mythology and Traditions, 13 vols., Wellington:1887-1891, vi:pp.151-157; Clarke to Hobson, 15 June 1842, BPP, ii:pp.192-193; Taraia to Hobson, June 1842, translated by Clarke, BPP, ii:p.195; Clarke to col. sec., 30 June 1842, BPP, i:p.194; Bunbury to Major of Brigade, 2 August 1842, BPP, ii:pp.162-163; W. Shortland to Hobson, 5 August 1842, BPP, ii:pp.195-196; W. Shortland to Stanley, 24 September 1842, BPP, ii:pp.189-190; Executive Council Minutes, 28-29 December 1842, BPP, ii:pp.457-464; W. Shortland to Stanley, 31 December 1842, $B P P$, ii:pp.456-457; Clarke, 'Half-Yearly Protectorate Report', 4 January 1843, BPP, ii:pp.121-122; E. Shortland, 'Report', 14 August 1843, BPP, ii:pp.352-353; New Zealand Colonist and Port Nicholson Advertiser, 17 January 1843, pp.2-3; New Zealand Gazette and Wellington Spectator, 21 January 1843, pp.2-3; Nelson Examiner and New Zealand Chronicle, 4 February 1843, p.192; Clarke (junior) to Hocken, 10 November 1904, George Clarke (junior), 'George Clarke Remembers: Three Letters Written by George Clarke, in 1904, to Dr. T.M. Hocken, of Dunedin', Auckland-Waikato Historical Journal, 55, 1989, pp.25-26; Rutherford, Heke's Rebellion, pp.13-16; Ward, Show of Justice, pp.58-61; McLintock, p.146; Moon, pp.199-200; Evans, Truth and Obedience, pp.74-77 \& 86-87; C.H. Wake, 'George Clarke and the Government of the Maoris: 1840-45', Historical Studies, Australia and New Zealand, 10:39, 1962, pp.348-351; Yeo, pp.37-40; Adams, Fatal Necessity, pp.219-221; Wards, Shadow, pp.60-69

${ }^{124}$ New Zealand Gazette and Wellington Spectator, 21 January 1843, p.2

125 Bunbury, Reminiscences of a Veteran, iii:p.162
} 
Hobson perceived success. They published a notice in Te Karere o Nui Tireni, the Maori Gazette, asserting the government's authority over internecine Māori affairs such as those which had recently occurred involving Taraia.

The thoughts of the Governor were, that you were mistaken, or confused; you did not know that he was sent to protect you all; none are excepted; if any one gets up to kill another, the Governor will also; had Taraia known this, indeed, he would have been out of sight. Now, the Governor says, leave, stop; you natives have all heard (my) the Governor's rule or law, which is this, that if any one man after this kills a man, indeed the Governor will get up also. ${ }^{126}$

Clarke explained to the Executive Council that his use of the phrase which translated into English as 'get up' was owing to it being 'a very expressive term in the Maori language, which the natives perfectly understood, and conveyed the meaning that the Governor would interfere and compel them by force a discontinuance of their savage customs'. ${ }^{127}$

Five months later Ngāi Te Rangi suffered another raid, this time at the hands of Ngāti Whakaue. The Ngāti Whakaue tauā killed a number of Ngāi Te Rangi at Maketū as utu for the disappearance of a young rangatira on their lands. Again kaitangata was practised. The threat made by the Crown, circulated in Te Karere o Nui Tireni, had been ignored. Acting-Governor Willoughby Shortland (Hobson had died in September), brother of SubProtector Edward Shortland, expressed his desire to dispatch troops against Ngāti Whakaue. When the chief protector and other colonial officials - including Chief Justice William Martin and Attorney-General William Swainson - expressed doubts about the legality of such an action, the troops were instead dispatched to prevent Ngāi Te Rangi from exacting violent utu. Doubts about the legality of employing troops arose from the belief that Eng-

\footnotetext{
126 Te Karere o Nui Tireni, 1 August 1842, pp.31-34, translated by Clarke, BPP, ii:p.469

127 Minutes of the Executive Council, 28 December 1842, BPP, ii:pp.457-459
} 
lish law could not be considered to be in force where chiefs had not signed the Treaty of Waitangi, or had signed it without a clear understanding of the document. As Acting-Governor Shortland wrote to Lord Stanley in forwarding the protectors' half-yearly reports: '[t]he question raised by the law officers of the Crown as to their [Māori] amenability to British law, leaves the treatment of such cases a matter of great difficulty and delicacy'.$^{128}$

Despite the doubts expressed by a number of colonial administrators, Shortland sent his brother Edward and Clarke (junior) to inform Ngāti Whakaue that if they did not make peace and recompense, he would 'get up' as indicated in Te Karere o Nui Tireni. Ngāti Whakaue rangatira Tohi Te Ururangi responded angrily to the acting-governor's threat, as recorded by SubProtector Shortland.

His murder at Tuhua was just according to their Ritenga [custom]. He wd. not give up the 2 slaves. He had lost his son, \& who was to fetch water for him. As to his eating the bodies of his enemies that was his delight. There were plenty of pigs for the Governor - But he preferred the flesh of his enemies - If the Governor got up to fight in this quarrel, he would be to blame. They would not begin fighting with the Pakeha - but if war commenced they would not be behind hand. He would eat them also. ${ }^{129}$

As had earlier been the case with Taraia, however, Ngāti Whakaue were willing to provide compensation and promise peace if the Crown were willing to station troops among them to protect them from other iwi. As noted above, an uneven acceptance of peace would leave iwi vulnerable and exacerbate Māori violence. Instead of troops, Ngāti Whakaue received a subprotector of aborigines stationed to their district. ${ }^{130}$

\footnotetext{
128 W. Shortland to Stanley, 15 June 1843, BPP, ii:pp.120-121; Minutes of the Executive Council, 16 \& 17 June 1842, BPP, i:p.193; see also: Stanley to FitzRoy, 10 February 1844, BPP, ii:pp.171-174

${ }^{129}$ E. Shortland, journal, 5 December 1842, micro-MS-0356, ATL

130 ibid., 3-20 December 1842, micro-MS-0356, ATL; Gibbons, pp.135-139
} 
The examples of Taraia and Tohi Te Ururangi show that Māori strongly objected to Crown interference in Māori violence. While they readily admitted that Māori-Pākehā disputes could be policed by the Crown, Māori were not willing to submit internecine conflicts to Crown law. Both Ngāti Maru and Ngāti Whakaue, however, informed the governor that if the Crown could protect them from the tauā of other iwi, they would practise peace.

The desire for peace and Pākehā settlement was not, however, universal. A Ngāti Whātua man named Motarou complained to Polack while the trader was visiting Kaipara that Pākehā were 'overrunning the land, so that wars must in a short time cease'. He stated that '[w]ar was his delight; and it had been the sole pleasures pursued by his ancestors (tepuna [tūpuna]) and ought to be so of their children'. 'He did not want to see a white face', Polack reported, 'he had heard to the northward ... a chief was made to feel ashamed in killing his own slave, and that the bodies were obliged to be eaten in secrecy and silence'. Motarou told the trader that 'he would sooner eat all the white men himself, than be reduced to a state so truly abject', and concluded by asserting he 'would live to spite the white men, and break his fast on a fresh slave every morning' ${ }^{131}$

Referring to the governor's declaration in Te Karere o Nui Tireni, Maketū rangatira Ponga told Sub-Protector Shortland that

they had heard that if they persisted in fighting the Govr. would get up - But they thought this very unjust. They had never invited him or consented that he should be their Chief. What mattered it to the Pakehas their killing each other. Better leave them to settle their own

131 Polack, New Zealand, i:pp.174-175, emphasis in original 
quarrels according to their own customs \& they should remain friends with the Europeans. ${ }^{132}$

Taraia, too, had invoked this defence of his actions; neither rangatira had signed te Tiriti o Waitangi.

It was not, however, only Hauraki and Bay of Plenty iwi who opposed Pākehā intervention in Māori affairs. In mid-1842 the chief protector reported:

[d]uring my late tour of the northern part of the island, I had to correct, as far as possible, a general notion prevalent among the chiefs who had signed the treaty, viz., that in ceding the sovereignty they reserved to themselves the right of adjudicating according to the native custom in matters purely native, while they ceded the right of Government in matters not only of the white, but between the white and the native, and have received several remonstrances to this effect from parties inimical to the Government. ${ }^{133}$

Māori who did not sign te tiriti believed they still had the right to resolve internecine Māori issues; those who had signed clearly believed they had retained such a right in signing.

Although they certainly did not feel they had to, Māori sometimes submitted their internecine disputes to colonial officials for mediation. Alleged Pākehā purchase of disputed land, or of land which many hapū lay claim to but had not been consulted with prior to sale or compensated for following purchase, was sometimes discussed with protectors or brought before land claims

\footnotetext{
132 E. Shortland, journal, 5 December 1842, micro-MS-0356, ATL

133 Clarke, 'Half-Yearly Report', 18 June 1842, BPP, ii:pp.190-192
} 
commissioners. As the missionaries had done from 1828, the protectors too were sometimes able to intervene to secure peace between hostile Māori.

Later recalling his December 1842 visit to Hauraki and the Bay of Plenty, Sub-Protector Shortland wrote that he had 'found the whole population of the district in a great state of excitement, owing to its having been discovered that a wife of one of the principal chiefs, named Te Mutu, had proved faithless'. Shortland had arrived to find a tauā of two hundred toa had gone to the kāinga ('Maunga-tapu') of the man with whom the chief's wife had committed pūremu (adultery) seeking utu. Shortland quickly followed the tauā, noting: 'it was a part of my duty to prevent, as far as possible, any breach of the peace'. Te Mutu demanded 'two particular pieces of land and a large canoe ... besides a quantity of miscellaneous valuables' as utu, and in return offered to 'give up his claim' to the woman involved. The other party initially refused this transaction, so Shortland 'determined to take up my quarters in the village till the dispute was settled, hoping my presence would contribute to an amicable arrangement'.

Utu for the pūremu was achieved the following day, with the land, waka, and 'miscellaneous valuables' in the form of muskets, iron pots, and tools being given up, and a feast of pork shared. The sub-protector noted that his assistance had been allowed because ' $[t]$ he friendly interference of a stranger in their quarrels is never taken amiss by the New Zealanders'. Pākehā assistance, he wrote, could 'prove serviceable by enabling the weaker party to yield with safety to their honour, on the plea that their doing so was owing to such interference'. ${ }^{134}$

\footnotetext{
${ }^{134}$ Edward Shortland, Traditions and Superstitions of the New Zealanders [1854], second edition London:1856, pp.237-240; Ward, Show of Justice, p.50
} 
Shortland believed that North Island Māori 'universally recognized the right of Government to apply English law to all cases in which Europeans, as well as natives, were concerned'. In disputes which did not involve Pākehā, however, 'they had always refused to consent to the application of our laws'. Or, if one side did seek Pākehā assistance, he continued, it was 'the suffering party, who were anxious to use our laws, or any other means, to obtain satisfaction'. These requests, the sub-protector concluded, were, however, purely self-interested, and 'if, the next day, they had committed a similar offence, they would have denied the authority so anxiously invoked' the previous day. ${ }^{135}$

Before FitzRoy left England to begin his tenure as governor of New Zealand, he received instructions from Lord Stanley regarding Māori violence.

The right of making peace and war is one of the essential attributes of sovereignty, and although we may not be always able to prevent recourse to arms between hostile tribes, yet, I think, we should never recognize their right to arrange their difficulties in this manner, and should always be at hand, by friendly mediation, or, when we have the means, by overpowering force, to arbitrate between them, and uphold our arbitration. Above all, we should set our face steadily against the horrible practice of cannibalism, and declare that a recourse to it by any tribe will lose them our protection.

FitzRoy was told that he must, however, 'never attempt to interfere, and fail of success'. ${ }^{136}$

135 Edward Shortland, The Southern Districts of New Zealand; a Journal with Passing Notices of the Customs of the Aborigines, London:1851, pp.134-135

136 Stanley to FitzRoy, 14 May 1843, BPP, ii:p.189 
In early-1844 FitzRoy was introduced to Donald McLean. McLean was fluent in te reo Māori and through his engagement in the felling and selling of timber in the Hauraki district, held good relations with Ngāti Paoa. FitzRoy offered McLean employment as a clerk and assistant interpreter in the Protectorate office, and McLean accepted. He was soon promoted to subprotector, western district - based at New Plymouth and responsible for an area stretching from Kāwhia south to Taranaki and inland to Taupō. ${ }^{137}$

McLean had arrived in Sydney from his home island of Tiree, in the Scottish Highlands, on 10 April 1839. Not yet twenty years of age, he had walked over the Blue Mountains to Bathurst, where he secured employment on a sheep station. He soon tired of managing sheep in the New South Wales bush, however, and returned to Sydney, from where he sailed for New Zealand. Seuss-like, biographer James Cowan observed of McLean's childhood, '[h]e was a boy of the out-of-doors, the hills and the sea, that lad of Tiree' McLean settled quickly into colonial life in New Zealand. ${ }^{138}$

Cowan made much of McLean's Highland ancestry and upbringing in his hagiographical biography, suggesting this 'predisposed him' to Māori tradition and custom. Nevertheless, McLean was an agent of the Crown firmly engaged in attempting to colonise New Zealand. He was, for example, responsible for the acquisition of vast amounts of Māori land. ${ }^{139}$ In his role as sub-protector of aborigines, McLean was also charged with suppressing Māori violence. 'Yours', Chief Protector Clarke informed him, 'is a Mission of Peace' ${ }^{140}$

\footnotetext{
137 James Cowan, Sir Donald Maclean: the Story of a New Zealand Statesman, Dunedin:1940, pp.3-4

138 ibid., pp.2-3; Ward, Show of Justice, p.93; Ray Fargher, The Best Man Who Ever Served the Crown? A Life of Donald McLean, Wellington:2007, pp.5-14

139 Cowan, Sir Donald Maclean, pp.4-5 \& 10-11; Fargher, Best Man, passim, esp. pp.355-366

140 Clarke to McLean, 3 August 1844, MS-Papers-0032-0215, Object\#1014172, ATL
} 
In December 1844 word reached colonial officials that a Ngāti Tūwharetoa tauā was assembling under rangatira Te Mananui Heuheu Tūkino. The tauā was gathering in order to attack Te Thupuki pā near the mouth of the Whanganui, seeking utu for the recent deaths of a number of their toa near there. CMS missionaries Richard Taylor and John Skevington wrote to McLean early the following year, noting that they had attempted to mediate peace, but had been unsuccessful. 'We think it therefore highly important that as the Protector of Aborigines for this district you should be present', the evangelicals wrote, concluding 'we jointly request you to visit this district immediately'. Sub-protectors McLean and Forsaith were dispatched, along with Bishop Selwyn, the superintendent of the southern division, Major Richmond, and the frigate Hazard, commanded by Captain Robertson, to try and secure peace; in part because of fears the Māori conflict would affect Pākehā settlers at the fledgling Wanganui township.

After a hui which lasted a number of days - negotiations being, according to Cowan, 'chiefly conducted by Mr. Maclean' - the Tūwharetoa tauā agreed to perform a haka, which included the firing of pū, within sight of their intended victims, then to return to Taupō with utu having been satisfied. With the assistance of both sub-protectors and the missionaries a peaceful resolution to the need for utu was achieved. ${ }^{141}$ Similar peace negotiations were repeated later that year when Taylor and McLean intervened between a tauā of

${ }^{141}$ Taylor and Skevington to McLean, 8 January 1845, MS-Papers-0032-0600, Object\#1015141, ATL; Taylor to McLean, 16 January 1845, MS-Papers-0032-0600, Object\#1015623, ATL; McLean to Taylor, 16 January 1845, MS-Papers-0032-0600, Object\#1023283, ATL; NZSCSG, 1 February 1845, p.2; Nelson Examiner and New Zealand Chronicle, 15 February 1845, p.199; BPP, v:pp.173-181; Cowan, Sir Donald Maclean, pp.12-14; Fargher, Best Man, pp.23-26 
500 toa from Rotorua and Hauraki, led by Ngāti Tamaterā rangatira Taraia, and Ngāti Ruanui and Ngāti Raura at Waitōtara. ${ }^{142}$

McLean was, Cowan declared, 'continually kept busy with diplomatic missions to native tribes, making peace between them, buying land for pakeha settlement from them, and composing differences between the races which might but for his efforts, have led to war' ${ }^{143}$ Swollen with admiration for his hero of 'peaceful colonisation', Cowan failed to understand that the middleprong of his trident of 'diplomatic missions' had a large impact on those which he placed either side of McLean's role in acquiring Māori land for the Crown. Less hagiographical than his predecessor, recent biographer Ray Fargher attempted to account for McLean's conflicting roles by giving him two separate personalities: one whose interests lay with Māori and one whose loyalty was to Crown colonisation. ${ }^{144}$ The Crown acquisition of Māori land both aggravated Māori-Pākehā disputes, and, as is examined in chapter six, exacerbated internecine Māori violence. Or, from a colonial perspective, as recalled by Sub-Protector Clarke (junior), both pre- and post-contact Māori warfare severely impacted European land purchase. ${ }^{145}$

As had been the case prior to 1840 , following the signing of te Tiriti o Waitangi uninvited Pākehā intervention in Māori affairs, including violence, remained unacceptable to rangatira, both signatories to te tiriti and those who opposed the accord. As a result, Hobson, then Shortland, then FitzRoy, informally adopted a position which entailed effectively ignoring Māori who

\footnotetext{
142 Taylor to McLean, 27 September 1845, MS-Papers-0032-0600, Object\#1025666, ATL; Clarke to McLean, 31 October 1845, MS-Papers-0032-0600, Object\#1000954, ATL

143 Cowan, Sir Donald Maclean, p.27, italics in original

144 Fargher, Best Man, passim; Richard Hill, 'Imperial Vision', New Zealand Books, 18:3, 1998, p.17

145 Clarke (junior), Notes, pp.58-60
} 
committed 'offences' which did not affect Pākehā - the two Bay of Plenty incidents involving kaitangata excepted. The Colonial Office supported this stance, but reiterated their insistence that Māori were British subjects, subject to British law. ${ }^{146}$

From concern as to the legality of becoming involved in Māori conflicts, which arose from the 1842 Bay of Plenty incidents, in 1843 the Colonial Office ruled that British sovereignty had been established throughout the entirety of New Zealand in 1840 - whether or not their rangatira had signed te Tiriti o Waitangi, all Māori were declared to be British subjects. The Colonial Office noted that the decision to extend sovereignty over New Zealand had been made not only to protect Māori from the perils of European settlement, but also to end their 'savage' customs. ${ }^{147}$

In 1844 Governor FitzRoy introduced a Native Exemption Ordinance. Under the ordinance, Māori arrested for crimes other than rape or murder were allowed to remain free until their trial, and Māori found guilty of theft could conciliate utu by paying four times the value of the goods stolen. Influenced by the same strong Christian faith which was to later sour his close friendship with Darwin, FitzRoy's ordinance was designed to prevent the imprisonment of Māori who broke British law in offences against Pākehā. More importantly for the purposes of this study, however, the Native Exemption Ordinance formalised the previously informal policy of ignoring internecine Māori 'crime': unless iwi requested assistance, the police magistrate would not generally intervene in issues not affecting Pākehā. The Native Exemption Ordinance brought the law into line with established practice; in reality,

\footnotetext{
146 Hill, Policing the Colonial Frontier, i:pp.216-218

147 Ward, Show of Justice, p. 62
} 
Māori were no less amenable to British law after the ordinance was passed than before. ${ }^{148}$

Upon the conclusion of his governorship, FitzRoy observed that ' $[\mathrm{t}] \mathrm{he}$ knowledge of native usages and language, which the protectors must possess, and their own personal influence among the aborigines, enabled them to allay many a fast increasing feeling of vindictive anger, - to prevent many a serious quarrel'. The protectors were, he announced, 'the eyes and ears of the executive authorities at each of the settlements, with reference to the aboriginal people'. FitzRoy's successor disagreed with the importance of the protectorate, despite the governor's parting assertion: 'how those authorities will contrive to carry on their duties efficiently without such assistance, I am unable to conceive' ${ }^{149}$

Captain George Grey had been advocating the quick, forced assimilation of indigenous people of British colonies since 1840. That year he wrote to London from South Australia 'on the Best Means of Promoting the Civilization of the Aboriginal Inhabitants of Australia', criticising the colonial policy of allowing Aboriginal peoples of South Australia to maintain their traditional customs, beliefs, and ways of life provided they did not interfere with settlers. Grey demanded they be rapidly made subject to British law instead. ${ }^{150}$ The New Zealand governors who preceded Grey had not shared his vision of forced assimilation - even had they wished to assimilate Māori, they had not the resources. When Grey was appointed governor of New Zealand in

\footnotetext{
148 ibid., pp.66-71; Ward, 'Law and Law-enforcement', pp.133-134; Hill, Policing the Colonial Frontier, i:pp.226 \& 364; Sinclair, Origins, pp.35-36; Orange, Treaty of Waitangi, pp.112-113; Wake, 'George Clarke and the Government of the Maoris', pp.355-356; Clarke, Final Report, pp.10-11; Fargher, Best Man, p.39

${ }^{149}$ FitzRoy, Remarks, pp.63-64

150 George Grey, 'Report on the Best Means of Promoting the Civilization of the Aboriginal Inhabitants of Australia', 4 June 1840, BPP, iii:pp.165-169; Terry, pp.212-217; McLintock, p.108; Ward, Show of Justice, p.36; Adams, Fatal Necessity, pp.212 \& 226
} 
1845, however, because of the need to suppress Māori rebellion his budget was triple that of FitzRoy's. With his vastly increased resources, Grey set about attempting to speedily and forcefully assimilate Māori into British colonial rule by 'civilising' them and making them subject to British law. ${ }^{151}$ Much to FitzRoy's disbelief, four months after taking over the governorship, Grey abolished the protectorate. Chief Protector Clarke was thus dismissed on 1 March 1846. His belief that Māori 'should be led, not forced, into the observance of British law' was contrary to Grey's vision. ${ }^{152}$

Although he had declined the position which superseded the post of chief protector, that of native secretary, Clarke acted in the role until 1 July 1846, when a replacement was able to be found. Clarke was replaced by J.J. Symonds, previously Grey's private secretary. Symonds was succeeded by Dillon, who was replaced by Nugent. Symonds, Dillon, and Nugent were sycophants, performing exactly as instructed by the governor. Grey replaced the sub-protectors with 'commissioners for the extinguishment of native land claims by fair purchase' - colonial officials who were to speed up the Crown purchase of Māori land to on-sell to eager Pākehā settlers. ${ }^{153}$

a

Camping near a destroyed pā in the Hauraki district in January 1834, Yate observed, while looking at the nearby 'monument of the most barbarous disposition, and warlike propensities of the Bay of Islanders', that '[t]hese

\footnotetext{
151 Buick, New Zealand's First War, pp.217-218; Ian Wards, 'The Generalship of Governor Grey, 1846-52', in Peter Munz (ed.), The Feel of Truth: Essays in New Zealand and Pacific History, Wellington:1969, p.95; Jonathan Adams, 'Governor FitzRoy's Debentures and their Role in his Recall', NZJH, 20:1, 1986, pp.46-47

${ }^{152}$ Clarke, Final Report, p.12, emphasis in original

153 Walker, pp.105-106; Sinclair, Origins, pp.31-35; Clarke to McLean, 6 February 1846, MSPapers-0032-0215, Object\#1013264, ATL; Yeo, pp.90-118; McLintock, pp.193-213; Shroff, pp.278279; Fargher, Best Man, pp.31-35
} 
times are now nearly over in New Zealand as the gospel spreads it will carry love and peace along with it and will convert swords and spears into hooks and plough shares'. ${ }^{154}$ Success in the suppression of Māori violence was, Yate perceived, on the horizon. In attempting to suppress Māori violence, deemed necessary for their 'civilisation' and Christianisation, missionaries had pleaded that killing one another was detrimental to their people - that a time may one day come when they would need to unite against a foreign force, and killing one another now would only harm their ability to repel such an enemy in the future.

As colonials officials too sought to suppress Māori violence, they asserted that the colony could not be effectively governed without a significant armed force to enforce British rule, and had pleaded with the Colonial Office to supply such a force. The Colonial Office had been sympathetic, but until the rebellion of the mid-1840s was unwilling to part with the necessary expense such a force required. ${ }^{155}$ Carleton argued of his biographical subject Henry Williams: '[i]n peace he handed [New Zealand] over to the new Government, who had only to maintain what he had achieved.'156 'Only' indeed - in 1845 military support became urgently essential; and with the urgent necessity of military support for colonial rule came a further development in the European focus on Māori violence. While continuing to seek to suppress internecine Māori violence, the Crown began to utilise Māori violence in the promotion of colonisation.

\footnotetext{
154 Employing typical evangelical language, here Yate drew on the biblical texts Micah 4:3 and Isaiah 2:4 (or perhaps reversed Joel 3:10). In February 1832 Henry Williams asked '[w] hen shall the glorious day appear when the sword shall be turned into ploughshare and the spear into a pruning hook, and the nations learn war no more'; H. Williams, 26 February 1832, Early Journals, p.226; Yate, journal, 15 January 1834, MS-2544, ATL

${ }^{155}$ Wards, Shadow, p.95

156 Carleton, i:p.245
} 


\section{Chapter Five \\ '[H]orrible instruments of colonial law': the Port Phillip Native Police and the Utilisation of Aboriginal Violence}

As the fledgling Port Phillip District grew, the New South Wales colonial government faced increasingly vocal demands from settlers regarding the Aboriginal peoples of the colony. On the one hand the government experienced mounting popular protest at the expenditure of public funds on Aborigines in the wake of a perceived failure to protect the settlers from Aboriginal 'outrages'. At the same time, colonial administrators received increasing philanthropic calls for greater protection of Aboriginal peoples. One response to this wave of dissatisfaction was to combine attempts to 'civilise' Aborigines with efforts to protect settlers from Aboriginal thefts and violence. The result of this amalgamation was the establishment of a Native Police Corps in the Port Phillip District, which operated in various forms from 1837 to 1853 . This police force, it was envisioned, would both 'civilise' Aboriginal troopers and protect European settlers. Specifically, the Native Police were enlisted to prevent or punish, often violently, Aboriginal 'outrages' against Europeans, while simultaneously adopting the habits of 'civilisation' to pass on to their own people. The recruitment of Aboriginal men from some language groups to police their own people, as exemplars of 'civilised' behaviour, as well as other language groups, through coercion, marked a colonial attempt to utilise Aboriginal violence for the purposes of colonisation.

In September 1838 a pastoralist on the Murrumbidgee wrote to the Sydney Herald using the pseudonym 'Anti-Hypocrite' complaining of the expenditure of public funds on attempts to 'civilise' and Christianise Aborigines. 
From one quarter comes a demand for an "increased police force," to suppress the violence, rapine, and bloodshed perpetuated by these hordes of Aboriginal cannibals, to whom the veriest reptile that crawls the earth holds out matter for emulation ... and from another proceeds a claim for "salaries" forsooth! to defray the expenses of "Protectorship."

Anti-Hypocrite, who believed 'every man of common experience in the Colony, and of common sense' knew the Aborigines to be 'the most degenerate, despicable, and brutal race of beings in existence', declared: '[a]ny attempt to civilize the Aboriginals of New Holland is futile and vain'. ${ }^{1}$ Such protests were common in colonial newspapers. As Michael Cannon observes, for most settlers ' $[t]$ he price of wool was far more interesting than the fate of people whose whole way of life they had so casually shattered.' ${ }^{2}$ Thus 'rifle bolts clicked in concert with the shears' on the New South Wales frontier. ${ }^{3}$

Writing on behalf of 'The Colonists' the following month, a Sydney Herald correspondent reiterated the demand for 'an efficient itinerating mounted police force to preserve their property from being plundered or destroyed, and the lives of their servants taken by these "interesting" creatures, as the canters call them'. Instead, the author bemoaned, the Aboriginal peoples of the colony 'are to have, it seems, a whole tribe of "protectors" quartered on the Colonial funds'. 'The whole gang of black animals', the writer concluded, 'are not worth the money which the Colonists will have to pay for printing the many documents upon which we have already wasted too much time. ${ }^{4}$ 'Pshaw!', a group of squatters later complained, 'a few mounted police, well

\footnotetext{
${ }^{1}$ Sydney Herald, 19 September 1838, p.4; see also: 14 November 1838, p.2

${ }^{2}$ HRV2A, p.xv

3 Reynolds, 'The Land, the Explorers and the Aborigines', p.214

4 Sydney Herald, 5 October 1838, p.3
} 
armed, would effect more good among the aborigines than the whole preaching mob of the protectors in ten years'.$^{5}$

Meanwhile, philanthropists requested police protection for Aborigines, and further reported that Aborigines themselves were making the same request. Tuckfield wrote:

the natives particularly complained of the want of protection, intimating, that as the white men had killed some of their fighting men, the great governor ought to send them the police to protect them from the violent and revengeful attacks of those tribes whose forces have not been so much weakened through the same cause; but as the natives are not amenable to British laws, and as no law has been framed to meet the exigence of their case, and especially as they have been allowed to butcher each other, and that in the presence of Europeans, with impunity, no promise of protection, such as they required, could be made to them. ${ }^{6}$

Together, the four embodiments of the Port Phillip Native Police Corps preceded, coexisted with, and outlasted the Port Phillip Protectorate.

In this chapter it is argued that at the same time as colonial officials and evangelicals were attempting to suppress Aboriginal violence, the Crown also sought to utilise Aboriginal violence in the promotion of colonisation. A key facet of investigation into this is an analysis of Aboriginal agency in the Crown's utilisation of Aboriginal violence. This examination of the simultaneous attempted suppression and utilisation of Aboriginal violence by the state highlights the paradox of the concurrent portrayal of the Aboriginal peoples of New South Wales as both homogeneous and heterogeneous. Moreover, in this chapter the further paradox of recruiting Aborigines to po-

\footnotetext{
${ }^{5}$ George Dunderdale, The Book of the Bush: Containing many Truthful Sketches of the Early Colonial Life of Squatters, Whalers, Convicts, Diggers, and Others who Left their Native Land and Never Returned [1870], Melbourne:1973, p.268; Mitchell, 'The galling yoke of slavery', pp.126-131

${ }^{6}$ Tuckfield, 'Report for the year ending December 1842', nd, enclosed in Gipps to Stanley, 3 April 1843, Aborigines (Australian Colonies), pp.257-259, SLV
} 
lice other Aborigines, often violently, while simultaneously attempting to have them adopt the habits of 'civilisation', is identified and explored.

In July 1837, New South Wales Colonial Secretary Edward Deas Thomson forwarded to Port Phillip Police Magistrate Captain William Lonsdale a recommendation regarding the use of Aborigines as Native Police. In recommending the establishment of a Native Police Corps, 'thereby gaining at once their affections and sympathy for us rather than against us', Alexander Maconochie cited the example of sepoys employed in India - yet another illustration of the British utilisation of indigenous violence for colonisation. Maconochie's plan was centred upon the 'civilisation' of the members of the force - a goal which remained through all four embodiments of the Corps. ${ }^{7}$

Less than two months later Lonsdale was granted approval to establish a Port Phillip Native Police Corps. ${ }^{8}$ The police magistrate established the force hoping that it would be used in 'preserving the peace and good order of the district, in apprehending runaways and preventing Aborigines committing any depredations on the white population, or if such should be the case in discovering and apprehending the offenders'. He stipulated that ' $[t]$ he men forming the corps must by judicious means be taught to give up their native habits ... [and] led to believe that belonging to the police places them in a very superior situation, and that all the barbarous practices of their country are unworthy of their participating in', noting '[o]ne of their first customs which should be attempted to be broken is that of joining in the quarrels of

\footnotetext{
7 Maconochie to Bourke, 10 June 1837, enclosed in Thomson to Lonsdale, 22 July 1837, VPRS-19, unit-2:item 37/77, PROV; Barry Bridges, 'The Native Police Corps, Port Phillip District and Victoria, 1837-1853', JRAHS, 57:2, 1971, p.113

${ }^{8}$ Thomson to Lonsdale, 4 September 1837, HRV2A, p.244
} 
one tribe against another'. Yet it was the continuation of these traditional animosities which made the Native Police so effective. 'It is of course not intended they should discontinue practising those customs which are useful', Lonsdale added, such 'as that of tracking footsteps.' ${ }^{9}$

Colonial administrators expected that Native Police troopers would become 'civilised', giving up their 'uncivilised' behaviours, except, of course, those deemed useful. The frontier reality differed markedly from government expectations, however, and the 'civilisation' aim was largely unsuccessful. Ostensibly the Native Police were to enforce order on the frontier with minimal violence while they themselves became 'civilised' and in turn 'civilised' other members of their language groups. In actuality, the Native Police violently policed the frontier, and the troopers themselves further exploited their position to attack their traditional enemies.

The employment of Native Police built upon a history of utilising Aboriginal skills through the European use of Aboriginal trackers. ${ }^{10}$ From the infancy of the Port Phillip District, Aboriginal trackers were employed by both the Border Police and the Mounted Police. ${ }^{11}$ The Border Police were a mounted force which operated in the more remote regions of the district. Foster Fyans' eighteen Border Police troopers were all former British soldiers who had been sentenced by court martial to transportation for desertion. The Mounted Police operated in areas of the colony where Europeans had settled in significant numbers. This force was also made up of transported British

\footnotetext{
9 Lonsdale to Thomson, 25 October 1837, HRV2A, pp.244-247

10 Bridges, 'Native Police Corps', p.113; Hazel King, 'Problems of Police Administration in New South Wales, 1825-1851', JRAHS, 44:2, 1958, p.64

11 Gipps to Stanley, 21 March 1844, Aborigines (Australian Colonies), pp.286-295, SLV; John O’Sullivan, Mounted Police of Victoria \& Tasmania, Sydney:1980, p.7
} 
ex-soldiers. The three Port Phillip police forces, Native, Border, and Mounted, were all military, not civil, policing operations. ${ }^{12}$

In later life, former-assistant protector Thomas remembered tracking five Aborigines with a Boonwurrung man, who, when they lost the tracks, consulted a koala who had called to them as they passed. 'The black stopped, and a parley commenced. I stood gazing alternately at the black and the bear. At length my black came to me and said, "Me big one stupid; bear tell me no you go that way"', Thomas and the tracker immediately changed course. 'Strange as it may appear', Thomas recalled, 'we had not altered our course above one and a half miles before we came upon the tracks of the five blacks' ${ }^{13}$ Europeans often found Aboriginal methods baffling, but Aboriginal skills were esteemed by Europeans; trackers often achieved their objectives.

On 28 October 1837 Lonsdale informed Thomson that he had appointed, at a salary of $£ 100$, Christiaan Ludolph Johannes de Villiers as superintendent of the Native Police. De Villiers was, prior to his appointment, living with a group of Aborigines and was reported 'not only to have gained their affection but a command over them'. In his place of birth the Cape Colony he had also had previous experience with the Khoikhoi ('Hottentot') Native Police. Fifteen Aboriginal men were initially enrolled and the police magistrate proposed issuing the troopers firearms, 'convinced that no harm will result from it'. ${ }^{14}$

\footnotetext{
12 O'Sullivan, pp.7-50; Marie Hansen Fels, Good Men and True: the Aboriginal Police of the Port Phillip District, 1837-1853, Melbourne:1988, pp.112-114

${ }^{13}$ Thomas, 'Brief Account', pp.426-427; see also: H. King, 'Problems of Police Administration', pp.57-65; Gary Presland, For God's Sake Send in the Trackers: a History of Queensland Trackers and Victoria Police, Melbourne:1998, pp.1-5

14 Lonsdale to Thomson, 28 October 1837, HRV2A, pp.250-251; Fels, Good Men, pp.11-15
} 
Nine weeks after his appointment, on New Year's Day 1838, de Villiers resigned following allegations made by Langhorne suggesting he was 'a person of notorious immoral character'. The abstemious missionary specifically accused de Villiers of 'inciting in the minds of the blacks an ill feeling against the Mission; and instructing them in the use of blasphemous expressions', and of drinking with his troopers. ${ }^{15}$ It has since been suggested that the missionary showed the Native Police superintendent 'about the same amount of Christian charity as the snake does to its prey'. ${ }^{16}$ In response, de Villiers labelled the mission personnel 'a set of $\mathrm{d}$ [amne]d hypocritical $\mathrm{b}$ [astard] $\mathrm{s}^{\prime} \cdot{ }^{17}$ Langhorne was, at his own suggestion, subsequently put in charge of the force by Lonsdale; however the troopers refused to serve under the missionary and left the camp at Narre Narre Warren. The first Native Police force thus lasted ten weeks, and undertook little, if any, actual policing. ${ }^{18}$

The second Native Police Corps was established when de Villiers was reappointed, at his own request, as Native Police superintendent on 18 September 1838. This force lasted just fifteen weeks - from de Villiers' reappointment to his second resignation on 15 January 1839 - but did engage in some policing. On 12 November 1838 a group of Taungurong, 'at least 400 in number', killed an assignee servant of Dr. Foster's, George Mould, and 'about 40 sheep and lambs'. The Aboriginal perpetrators were further accused of cannibalism based on a report that they had carried off a portion of the victim's body. The Native Police were immediately despatched. The force returned after three weeks. It had tracked the accused group 'a consid-

\footnotetext{
15 Langhorne to Thomson, 31 December 1837, HRV2A, pp.208-209; see also: Langhorne to Thomson, 31 May 1838, HRV2A, pp.220-222; Langhorne to Lonsdale, 20 December 1837, HRV2A, p.257

16 O’Sullivan, p.38

17 Langhorne to Lonsdale, 29 December 1837, HRV2A, pp.259-260

18 Fels, Good Men, pp.11-25; Bridges, 'Native Police Corps', pp.114-120; O'Sullivan, pp.36-38; Clark and Heydon, p.15; Thomas O'Callaghan, 'Police in Port Phillip and Victoria, 1836-1913', VHM, 12:4, 1928, pp.183-185; Foxcroft, pp.49-54; S.I. Miller, Police in Victoria 1836-1980, Melbourne:1980, pp.4-5; see also: HRV2A, pp.220, $296 \& 300$
} 
erable way along the Goulburn', but had failed to catch them, though it did return with two Aboriginal prisoners reported to have been implicated in other recent 'outrages' against settlers.

Considering the Taungurong were closely connected through kin and friendship ties with the Woiworung troopers, the Native Police 'failure' to apprehend the Taungurong accused is not surprising. The troopers were unwilling to police language groups with friendly connections to their own. The second Native Police Corps disbanded when de Villiers again resigned, this time in the face of criticism from Lonsdale regarding his failure to capture those accused of the depredations at Foster's station. The Native Police Corps was then placed under the superintendence of the newly founded Aboriginal Protectorate. ${ }^{19}$

Bookended by the first and second Native Police Corps was what Marie Fels labels 'a quasi-policing Aboriginal expedition'. In April 1838 a group of Aborigines, some of whom had been troopers in the first Native Police force and who would later enlist in the second, left the vicinity of Melbourne giving at least three different versions of their intentions. The party told Langhorne that they were headed west to favour the colonists by engaging in fighting the Wathaurong, the language group believed responsible for the deaths of explorers Joseph Gellibrand and G.B.L. Hesse the previous year. The expedition was then accosted by squatter Kenneth Clarke, who questioned their carrying a firearm. In response, the Aborigines produced a signed order from Lonsdale stating that one of their number was allowed to possess a musket. They informed Clarke that they were off to kill an Abo-

\footnotetext{
19 Rutledge to Lonsdale, 18 November 1838; Lonsdale to Thomson, 14 December 1838; Forster to Thomson, 22 December 1838; Thomson to Lonsdale, 7 January 1839 - HRV2A, pp.340-342; Fels, Good Men, pp.25-31, 43 \& 104-106; Clark and Heydon, p.15; O'Callaghan, pp.184-185; Robert Douglass Boys, First Years at Port Phillip: Preceded by a Summary of Historical Events from 1768, Melbourne:1935, p.74
} 
riginal man, Nanymoon, who was reported to have killed Thomas Learmonth's shepherd, Terence McMannis, and that they were going to bring back their victim's ears. Both reasons offered indicate Aboriginal violence for the benefit of Europeans, although there is no indication that the expedition was an officially sanctioned utilisation of Aboriginal violence.

Significantly, both Nanymoon and those accused of killing the explorers were of language groups who were traditional enemies of the armed party. In contrast to the aims pledged to Europeans, the expedition informed their Aboriginal acquaintances they were off to kill sheep. The expedition did not kill nor capture Nanymoon - he was arrested by Fyans in Geelong, imprisoned, and then freed after a Supreme Court trial in 1839. Nor does it appear that they engaged in any conflict with the Wathaurong accused of killing Gellibrand and Hesse. Their journey from Melbourne over the Werribee into the western district did, however, leave a wake of enraged settlers complaining of the destruction of their stock. ${ }^{20}$ Aborigines were perhaps learning that the promise of Aboriginal violence for European gain allowed them more freedom of action.

On 12 June 1839, Chief Protector Robinson wrote to Thomson in response to the colonial secretary having, four months previously, placed at his disposal de Villiers' Native Police Corps. Robinson suggested that the force be reestablished because, he believed, 'a Native Police Corps properly organized and conducted would be found of great advantage, to the community at large;

\footnotetext{
${ }^{20}$ Marie H. Fels, 'A Quasi-Policing Aboriginal Expedition in Port Phillip in 1838', $A H, 10: 2,1986$, pp.117-129; Fels, Good Men, p.26; Affidavits sworn before James Simpson, 27 April 1838, HRV2A, pp.294-297; Lonsdale to Thomson, 8 May 1838, HRV2A, p.220; Lonsdale to Thomson, 11 July 1838, HRV2A, p.303; principal gaoler to Lonsdale, 10 September 1839, HRV2A, p.304
} 
but more especially to the European Inhabitants, by restraining Bushranging, tracking out and apprehending run-away Convicts, and others; and by checking the predatory attacks of aboriginal natives for which specific $\mathrm{du}$ ties those people will be found admirably suited'. The chief protector further believed that this should be a Melbourne-based force, made up of Aborigines who had served in the previous forces under de Villiers and who had been longer acquainted with Europeans. These men, he asserted, would immediately prove to be effective police troopers because 'for the most part, they are isolated individuals belonging to remnant Tribes, now all but extinct and hence in their Political and Kindred relations are not likely to kindle strife, or engender hatred among the more uncivilized Tribes, against whom they might perchance be called to act'.

Robinson further mused that in addition to the reformed 'Central Police Corps', 'Domestic Police' - Aboriginal police forces of five men attached to each assistant protector - should be founded, but he wished for his subordinates to be better acquainted with their charges before this took place. He hoped these Domestic Police would allow Aboriginal agency in policing, thus Aborigines 'would be induced more readily to conform to such regulations, than to those, with which they had no share in Establishing'. ${ }^{21}$ La Trobe shelved Robinson's Central Police Corps for the meantime, but authorised the Domestic Police experiment. ${ }^{22}$

Robinson's suggestion for re-forming the Native Police came amidst calls from his assistant protectors to be allowed to employ Aborigines as police. In mid-winter 1839 Thomas wrote to Robinson on the hardships that the season was placing on Aboriginal peoples of the Mount Macedon district. This

\footnotetext{
21 Robinson to Thomson, 12 June 1839, VPRS-4490, unit-1, PROV, emphasis in original

22 Bridges, 'Native Police Corps', pp.120-121; Fels, Good Men, pp.32-41
} 
seasonal adversity was leading to 'outrages' being committed against the settlers, which in turn were causing settler retaliation. 'Never was there a more urgent plea for a Native Police than at present', Thomas asserted. ${ }^{23}$ Five weeks later fellow assistant protector Sievwright concluded his first sixmonthly report: 'I would submit that were a few Aborigines to be attached to me, as a Native Police much good would be easier detected ... and they would ensure the earliest intelligence of the predatory movements of the different Tribes by which notice they might at least be checked if not wholly prevented' ${ }^{24}$

In early-summer 1839, ‘[h]aving found repeatedly insufferable difficulties in endeavouring to trace the aboriginal tribes within my district, and to place myself in permanent contact with them, owing to native assistance', Assistant Protector Parker wrote to Robinson requesting that he be allowed to employ two or three Aborigines to assist him as police. Parker wished to employ men from the Wathaurong language group, as he was told they were presently at peace with the Djadjawurung and the Ngurraiillam, and that most Wathaurong were able to communicate with these language groups. Rather than policing Aboriginal conduct, however, Parker wished his police to assist him in overcoming the aforementioned difficulties he was experiencing in fulfilling his duties as an assistant protector. ${ }^{25}$ Robinson forwarded this request to La Trobe. ${ }^{26}$

\footnotetext{
23 Thomas to Robinson, 23 July 1839, Michael Cannon (ed.), Historical Records of Victoria, Volume 7: Public Finance of Port Phillip, 1836-1840, Melbourne:1998, pp.332-333

24 Sievwright, 'Report of Proceedings from March to August 1839 Inclusively', 1 September 1839, VPRS-13172, unit-1:discs-8-9, PROV; see also: Sievwright to Robinson, 15 October 1839, VPRS-13172, unit-1:disc-11, PROV

${ }_{25}$ Parker to Robinson, 3 December 1839, VPRS-13172, unit-1:disc-15, PROV; see also: Parker to Robinson, 8 April 1839, VPRS-13172, unit-1:disc-2,PROV

${ }^{26}$ Parker to Robinson, 3 December 1839, enclosed in Robinson to La Trobe, 5 December 1839, VPRS-10, item 39/290, PROV
} 
Having 'selected those whom I thought were eligible for the native police', Sievwright then 'endeavoured to instil the necessity of referring all their complaints and grievances (especially those concerned with the white population) to me, as their friend and Protector'. He reported that ' $t \mathrm{t}]$ hey understood and at once complied with my wish ... they without hesitation came to complain instead of taking those retaliatory steps which had already led to so much bloodshed'. Sievwright engaged his Aboriginal policemen in supplying him with information regarding the conduct of both other Aboriginal language groups and European squatters, and in bringing to him, forcibly, Aboriginal women living in Geelong. ${ }^{27}$ The assistant protectors thus employed Native Police to assist them in facilitating contact, restraining Aboriginal-European conflict, and suppressing Aboriginal violence, which sometimes meant utilising Aboriginal violence.

By mid-spring 1839 the assistant protectors had begun appointing Native Police troopers to assist them in their districts. ${ }^{28}$ In response, La Trobe cautioned Robinson, who in turn warned his assistant protectors, regarding making good use of the police given the cost to the government of employing them.

I cannot touch upon the subject of the aboriginal police again without repeating my hope, that the measure of its reorganization even in this modified form, which you or your Assistant Protectors have been so anxious to obtain, may prove to be one which you have well digested; and are prepared upon sound ground to consider likely to be of sufficient importance and efficiency to the cause to warrant the additional expense which it must necessarily entail. ${ }^{29}$

\footnotetext{
27 Sievwright, 'Report of the Proceedings \&c. from September 1839 to May 1840, both Inclusive', 1 June 1840, VPRS-13172, unit-1:disc-18, PROV

${ }^{28}$ Sievwright to Robinson, 15 October 1839, VPRS-13172, unit-1:disc-11, PROV; Dredge to Robinson, 20 November 1839, VPRS-11, item 39/26, PROV; Thomson to La Trobe, 17 December 1839, HRV2B, pp.761-763

29 La Trobe to Robinson, 21 November 1839, cited in Robinson to Sievwright, 21 November 1839, VPRS-13172, unit-1:disc-18, PROV
} 
The Legislative Council approved $£ 993$ for the Protectorate Native Police for 1840 , and this was not to be exceeded. ${ }^{30}$ As a result, the supply of rations to the Aboriginal troopers in return for their work was capricious. In February 1840 Dredge advised his superior that his Native Police were upset at not having yet been furnished with the clothing promised them upon enlistment. ${ }^{31}$ Thomas, too, was struggling with providing his troopers with rations, owing to the allowed budget being firmly set aside for 1840 and no earlier. ${ }^{32}$ These difficulties perhaps account for why Thomas 'had occasion to notice improprieties' in some of his initial enlistments, prompting him to seek permission to reselect his troopers in early-1840. ${ }^{33}$ Problems with supplying rations meant that although the assistant protectors continued to employ Aborigines as policemen until the end of 1841, their doing so was beset with problems and was thus done in a very irregular manner.

That the false promises and irregularity of guaranteed food and clothing rations upset Aboriginal enlistees in the Protectorate Native Police offers a good indication of Aboriginal motivations for enlisting in the force. In a scathing review of Aborigines in Colonial Victoria, Howe deplored Christie's discussion of the Native Police. '[W]hy', asked, 'should one group of Aborigines so ruthlessly destroy another?' ${ }^{34}$ Fels directly confronts this question in her history of the Port Phillip Native Police: ' $[t]$ he answer is that they didn't.' Although she proposes Howe raised 'a valid fundamental question', Fels sees the phrasing of his confrontational enquiry as 'a subtle manifesta-

\footnotetext{
30 Thomson to La Trobe, 17 December 1839, HRV2B, pp.761-763

31 Dredge to Robinson, 10 February 1840, VPRS-11, item 30/228, PROV

32 Thomas to Robinson, 23 November 1839, VPRS-11, item 39/288,PROV

33 ibid., 3 January 1840, VPRS-11, item 40/294, PROV

${ }^{34}$ K.R. Howe, '[Review of] Aborigines in Colonial Victoria 1835-86' AH, 4:2, 1980, p.206
} 
tion of the stereotype of the savage at work'. Both Howe's question and Fels' answer assume an Aboriginal homogeneity which is not so. One does not study the Napoleonic Wars - or the Anglo-Boer War, nor either World War, and so on and so forth - by asking 'why should one group of Europeans so ruthlessly destroy another?' War historians do not see Europeans as a homogeneous group, and thus their warfare as internecine and therefore difficult to justify. Fels goes as far as to suggest that the Native Police 'may be seen as an early stage in pan-Australian Aboriginal consciousness' ${ }^{35}$ Conversely, it is argued here that understanding the motivations of those Aborigines who enlisted in the Corps helps to break down the myth of pretwentieth-century Aboriginal homogeneity.

Fels quite rightly seeks to identify Aboriginal agency in Aboriginal participation in the Native Police. 'This is a study of one positive Aboriginal choice: it is', she declares of her book, 'a history of co-operation. ${ }^{36}$ As McGrath notes, Fels 'tended to attribute a great deal of autonomy to the Native Police, pointing out how they mediated between cultures'. ${ }^{37}$ By examining the Corps through this prism, however, Fels reinstates Aboriginal agency at the expense of investigating colonial reasons for employing Native Police. Moreover, in her desire to restore Aboriginal instrumentality to the Native Police, she understates Aboriginal reasons for joining the force which related to traditional inter-language group animosities, an investigation of which opposes the portrait of a homogenous and harmonious Aboriginal Australia. Fels argues that historians have 'replaced an earlier historical falsehood of a nonviolent frontier with a new stereotype of a violent one'. These violent histo-

\footnotetext{
${ }^{35}$ Fels, Good Men, pp.3n \& 6

36 ibid., p.2

37 Ann McGrath, 'Contested Ground: What is "Aboriginal History"?', in McGrath (ed.), Contested Ground, p.371
} 
ries, she declares, 'do not take account of positive Aboriginal choices'. ${ }^{38}$ In her desire to reconsider what she sees as overly-violent contact histories, Fels understates internecine Aboriginal violence and the European utilisation of traditional indigenous hostilities. Too intense a focus on indigenous agency can incline towards a return to the 'Noble Savage'.

Fels seeks to resolve the question '[w]hy would Aboriginal men want to join a police force of the foreigners who had taken over their land?' Her answer is that Aboriginal men joined the Native Police in an endeavour to share in the authority of the newly arrived Europeans, and that the prestige obtained by being a trooper, in addition to the material benefits, were a way for Aboriginal men to extend their influence within traditional society. In deemphasising inter-language group violence carried out by the Native Police, Fels unfairly accuses a number of historians of incorrectly portraying the troopers as traitorous murderers. ${ }^{39}$

It is true that the Native Police were not traitors, for Aboriginal Port Phillip was not homogenous, and that the term 'murder' is problematic. Despite Fels' claim, however, none of the historians she accuses suggest that the troopers were traitors. Native Police troopers did, however, kill other Aborigines - both within and outside of their official policing duties, both for traditional reasons and as an adaption to European invasion. Broome labels the founding of the Native Police '[t]he most fearful government decision' and suggests that its establishment in Port Phillip, along with later forces in New South Wales proper and Queensland, 'marked the absolute rock bottom

\footnotetext{
${ }^{38}$ Fels is here drawing upon Richard Broome, '[Review of] Aborigines in Colonial Victoria 1835-86 and Conquest of the Ngarrindjeri', Historical Studies, 19:76, 1981, pp.454-457; Fels, Good Men, pp.12

39 Fels, Good Men, pp.3 \& 224; Broome, Aboriginal Australians, pp.44-46; Christie, pp.71-78; Reece, Aborigines and Colonists, p.214; A.T. Yarwood and M.J. Knowling, Race Relations in Australia: a History, Sydney:1982, p.110; see also: Broome, Aboriginal Victorians, pp.43-46
} 
of government Aboriginal policy'. 'Not only was violence against the Aborigines being institutionalised', he notes, 'but several hundred Aborigines were being encouraged to hound and kill other Aborigines in the service of colonial expansion.' ${ }^{\prime 40}$ This blunt assessment may be true from a European viewpoint, but for Aborigines themselves this assigned homogeneity detracts from and masks the Aboriginal agency involved. As Corris notes, there was a 'lack of feeling of identity between Aborigines from different tribes', and the 'danger of turning some loose on others' was evident. ${ }^{41}$

Referring to the incident involving Bonjon discussed in chapter three, Fels asserts 'there is only one instance so far discovered of an Aboriginal person shooting another Aborigine'. ${ }^{42}$ In her desire to restore Aboriginal agency to the Corps and highlight Aboriginal adaption to European invasion, Fels clearly sees Native Police violence as completely distinct from traditional inter-language group violence. This distinction fits the pattern of Fels' diminution of the actions of the Native Police as a product of the European utilisation of Aboriginal violence. Moreover, Fels asserts that ' $[t]$ he meaning of the [Aboriginal] anxiety to possess guns is therefore not simply a matter of a desire for "improved" technology: it is to do with increased efficiency, but not, apparently, increased efficiency in inter-tribal violence. ${ }^{\prime 43}$ Although she acknowledges the appointment of Native Police altered inter-language group power relations, ${ }^{44}$ for Fels Aboriginal agency in their operations as Native Police troopers transcended the troopers' involvement with their language group's traditional acrimonious relations with other groups.

\footnotetext{
40 Broome, Aboriginal Australians, pp.44-45

41 Corris, p.110

42 Fels, Good Men, p.76, see also: pp.36 \& 100-103

43 ibid., p.37

${ }^{44}$ ibid., passim, esp. p.18
} 
A focus on the European exploitation of Aboriginal violence, however, may complicate, but does not denigrate, emphasis on Aboriginal agency. A key motivation for many troopers in joining the Corps, for example, concerned the potential for traditional inter-language group violence. One contemporary observed that the formation of the Port Phillip Native Police 'has ... been, and must continue to be, fraught with mischievous results'. 'It is in fact arming one tribe of natives against all other tribes with whom they are at enmity.' 'No native', he continued, 'will let slip the opportunity of killing wild black fellows - those of other tribes. These native policemen, on horseback, and furnished with guns, are dreadful enemies to the other wooden-weaponed natives; and they know how to make their position terrible.' ${ }^{45}$

Broome has noted an early Aboriginal appreciation of the importance of both firearms and horses, which in part explains Aboriginal interest in enlisting in the Native Police. ${ }^{46}$ 'I fear', Dredge wrote in early-1840, 'their principal inducement in becoming Policemen is the hope of possessing these muskets to render them a terror to their enemies'. The assistant protector believed 'it very questionable policy to issue Muskets to them at all', and added 'I shall hesitate along time before I shall allow their use'. ${ }^{47}$ Parker complained that Aborigines who frequented his Loddon Protectorate station told him that they would much rather be Native Police troopers than work on the station. When he responded with the sixth commandment, 'thou shall not kill', he was laughed at. ${ }^{48}$

As Fels herself notes, what Aboriginal men who expressed interest in joining the Native Police appeared to desire most was firearms, though she sees this

\footnotetext{
45 Richard Howitt, Impressions of Australia Felix, during Four Years' Residence in that Colony; Notes of a Voyage Round the World; Australian Poems, \&c., London:1845, p.196

46 Broome, 'Aboriginal Workers', pp.208-213; Broome, 'Aboriginal Victims and Voyagers', p.76

47 Dredge, diary, 24 January 1840, MS-5244, SLV

48 O'Sullivan, p.42
} 
desire as arising from intended uses other than internecine violence. ${ }^{49}$ Sievwright discovered that upon his departures into country foreign to his Aboriginal troopers 'they would not accompany me unless allowed the possession and use of fire arms'. The assistant protector refused their request because of a fear the guns would be used in inter-language group violence. ${ }^{50}$ The superintendent of the fourth and final embodiment of the Port Phillip Native Police Corps noted that he could not have convinced his troopers to enter foreign country were they not mounted. ${ }^{51}$ Native Police recruits maintained their belief that enemy Aborigines could steal their marmbula. ${ }^{52}$ Being armed with European weaponry and mounted on horseback helped the troopers overcome this natural fear: guns and horses were the message sticks required for safe passage through foreign country for Native Police troopers. ${ }^{53}$ Recruits knew that being armed and mounted gave them a significant advantage over their traditional enemies and other, traditionally feared, 'wild blacks'.

Access to firearms was not the only reason for wanting to become a Native Police trooper. At the encouragement of Merri Creek missionary Francis Edgar, Aboriginal man Charles Never was training to become a tailor. He soon tired of the trade, however, because, as Edgar's daughter recalled: '[h]e wanted to be something better'. 'Something better' was a Native Police trooper, a number of whom he had seen parading in Melbourne, and whose uniforms, horses, and 'idle life' he envied. Charles Never later joined the Corps as a tailor. ${ }^{54}$ Enlisting in the Native Police additionally offered young

\footnotetext{
49 Fels, Good Men, pp.75-77

50 Sievwright, 'Report of the Proceedings \&c. from September 1839 to May 1840, both Inclusive', 1 June 1840, VPRS-13172, unit-1:disc-18, PROV

51 H. Dana to La Trobe, 16 June 1843, VPRS-19, item 43/1038, PROV

52 Ellender and Christiansen, p.90; A.W. Howitt, 'On Australian Medicine Men', pp.23-59; Fels, Good Men, pp.165-166

53 A.W. Howitt, 'Notes on Australian Message Sticks and Messengers', pp.314-332

54 Edgar, Among the Black Boys, pp.95-96; Fels, Good Men, p.90
} 
Aboriginal men, whose access to Aboriginal women was traditionally restricted by Elders, increased access to women, both through heightening their status in women's eyes and through improved power, which enabled the troopers to acquire Aboriginal women from other Aboriginal men. ${ }^{55}$

Despite the assistant protectors' initial refusal, Protectorate troopers were issued firearms on occasion. The Native Police were specifically exempt from the ban on Aborigines carrying firearms discussed in chapter three. ${ }^{56}$ The chief protector stipulated, however, that ' $[t]$ he native constables attached to the Assistant Protectors were not designed for the service of remote districts but for the exclusive control of their own people' ${ }^{57}$ The Protectorate Native Police were employed to assist the assistant protectors in establishing contact with, and representing the needs and complaints of, other Aborigines within their districts. This, the third Native Police Corps, restricted as it was largely to intra-language group policing, thus offered Aboriginal enlistees far less than the possibilities presented by the earlier forces established under de Villiers. ${ }^{58}$

What limited Aboriginal violence the Protectorate Native Police force did utilise was largely the threat of violence, rather than actual conflict. During 1841 seven Port Phillip Aboriginal men - a number of whom had served in earlier embodiments of the Native Police - were employed as trackers to catch a group of Van Diemen's Land Aborigines. These wanted Aborigines had been brought across the Bass Strait by Robinson and then abandoned, and had thus committed 'outrages' upon settlers in order to survive in for-

\footnotetext{
55 Thomas to Robinson, 8 November 1846, VPRS-11, item 46/647, PROV; Parker to Robinson, 2 November 1846, VPRS-11, item 46/647, PROV

56 Robinson to assistant protectors, 8 July 1839, HRV2B, pp.724-727

57 Robinson to La Trobe, nd, enclosed in La Trobe to Thomson, 10 July 1840, cited in Fels, Good Men, p.34

${ }^{58}$ Fels, Good Men, p.34
} 
eign country, including the killing of two whalers at Westernport. The search for these victims of Robinson's much-celebrated earlier 'conciliation' of the Aboriginal peoples of Van Diemen's Land was conducted amid a great deal of fear among the European population of the district. Thomas noted that the majority of the stations in the area had been abandoned, the settlers having removed to Melbourne, and those leading the chase were reluctant to attempt to capture the accused without the assistance of additional Port Phillip Aborigines. The assistant protector reported that the success of the eventual capture had 'very much really depended upon' the efforts of the seven Port Phillip Aboriginal trackers. ${ }^{59}$ This success prompted the reestablishment of the Port Phillip Native Police Corps. ${ }^{60}$

In early-1842, perhaps in part because he is rumoured to have twice saved La Trobe's life, Henry Edmund Pulteney Dana was appointed superintendent of the re-established Native Police Corps. ${ }^{61}$ When approached by Dana and Assistant Protector Thomas regarding reforming the force, Billibellary, clanhead of the Wurundjeri-willam and a chief Elder (ngurungaeta) of the Woiworung, ${ }^{62}$ asked for a week to consider the proposal. For seven days he discussed with his people at night the merits and shortcomings of the Europeans' plan. On 24 February 1842 Billibellary was first to enlist in the fourth Native Police Corps. He stipulated, however, that he was a figurehead: 'I am

\footnotetext{
59 Thomas to Robinson, 5 \& 11 November and 2 December 1831, VPRS-11, items 41/411, 41/412, and 41/415, PROV

60 O'Sullivan, p.39; Fels, Good Men, pp.42-43; Rae-Ellis, pp.211-216

${ }^{61}$ O'Sullivan, p.39; J. Sadleir, 'The Early Days of the Victorian Police Force', VHM, 1:3, 1911, p.73; Leslie Blake, Captain Dana and the Native Police, Geelong:1982, passim

62 Presland, First People, p.18; Broome, Aboriginal Victorians, p.xxi
} 
king; I no ride on horseback; I no go out of my country; young men go as you say, not me.'63

Encouraged by Billibellary, twenty-four other Aboriginal men signed up. They did so on the promise that 'they should be clothed and Rationed the same as the Mounted Police'. The troopers were thus soon each issued with a pair of blankets, a pair of trousers, a blue frock, a shirt, a police jacket, a belt, and a cap. Dana enthused to La Trobe that he 'believe[d] that at no distant period they will become a most useful body of men generally, and especially when any outrages are committed by the Aborigines' ${ }^{64}$ It is difficult to know the true nature of the negotiations conducted and the promises made between Thomas and Dana on the one hand, and Billibellary and his people on the other. Even if assurances of access to horses and firearms and the promise of the chance of an advantage over traditional enemies were not explicitly made, however, the direct comparison made to the Mounted Police, that Billibellary knew the policing duties would involve departing country on horseback, and knowledge of the experiences of previous embodiments of the Native Police, all entailed these opportunities. The chance to utilise European-provided advantages to gain ascendancy over their traditional enemies was a leading motivation for Aboriginal men enlisting in the fourth Native Police.

The fourth Native Police force operated under the structure of Henry Dana and a fluctuating number of European sergeants, Aboriginal sergeants, and Aboriginal troopers, all of whom were each armed with a carbine, two pistols, and a sword. From June 1842 the force was based at the confluence of Merri Creek and the Yarra (a site now beneath an Eastern Freeway overpass),

\footnotetext{
${ }^{63}$ Thomas, 'Brief Account', p.404; Fels, Good Men, pp.49-56; Celia Thomas, 'Native Police', Police Life, November 1983, p.11; O'Callaghan, pp.185-186

${ }^{64}$ H. Dana to La Trobe, 31 March 1842, VPRS-19, unit-28:item-42/647, PROV
} 
but in September 1843 it was relocated to Narre Narre Warren. In 1845 Dana appointed his brother-in-law William Hamilton Walsh and his brother William Augustus Pulteney Dana to the force. ${ }^{65}$

As a general pattern, Dana's Native Police operated in two divisions of about twenty Aboriginal men each, under the leadership of a European sergeant. These divisions went out to the sparsely settled districts during the winter and spring, where they further split into groups of two or three men. These smaller groups established themselves on stations - usually those of highprofile squatters - acting as an effective deterrent to Aboriginal 'outrages', which occurred far more frequently during the May-November period of seasonal scarcity. ${ }^{66}$ The Native Police also investigated reported Aboriginal thefts of stock, sometimes only to find the accusations false, the loss of sheep having been occasioned by the neglect of shepherds. ${ }^{67}$ Outside of guarding stations and punishing Aborigines suspected of 'outrages', the Native Police carried government despatches, searched for Europeans believed to be lost in the bush, escorted high-profile Europeans, fought fires, pursued bushrangers, searched for survivors of shipwrecks, and guarded shipwrecks from plunder. ${ }^{68}$

65 Colonial Times (Hobart), 29 March 1842, p.4; La Trobe to Thomson, 10 February 1842, enclosed in Gipps to Stanley, 21 March 1844, Aborigines (Australian Colonies), pp.286-295, SLV; 'Rules and Regulations to be Observed and Performed by the Non Commissioned Officers and Troopers of the Native Police', H. Dana to Lonsdale, 29 November 1846, VPRS-19, unit-92:item-47/866, PROV; Fels, Good Men, pp.151 \& 223-234; Clark and Heydon, p.2

${ }^{66}$ At the same time that seasonal scarcity was occasioning Aboriginal 'outrages' against squatters in Port Phillip, similar problems were being experienced in Europe. In early-1847, during the austral summer, the 'latest from England', it was reported in the Melbourne Argus, was that '[g]reat distress amongst the poorer classes attended with violence, had manifested itself in Ireland, and in France, in consequence of the scarcity and high price of provisions.' 'The approaching winter was', the correspondent announced, 'looked forward to with alarm'. 'Outrages' were a natural response to starvation; Melbourne Argus, 22 January 1847, p.2; Fels, Good Men, passim, esp. pp.56-57, 117-118 \& 123; Fels, 'Quasi-Policing Aboriginal Expedition', pp.127-128

67 see for example: H. Dana to La Trobe, 20 August 1843, VPRS-19, unit-49:item-43/2189, PROV

68 Fels, Good Men, pp.62 \& 114; Sadleir, 'Early Days of the Victorian Police', p.74 
The principal idea behind the Native Police was that the threat of armed, mounted Aboriginal men who were highly skilled in tracking and surviving in what settlers perceived to be hostile country, would be enough to prevent 'outrages' being committed by Aborigines against Europeans. When Police Magistrate A. French heard that a group of Aborigines had arrived at his sheep station in the early-spring of 1842, he sent for the Native Police. French assumed the Aborigines had 'been concerned in some of the recent outrages on his property', so he had the troopers track them, and tell them 'with the greatest forbearance to go to Mount Rouse [Protectorate Station], where they would get provisions as it was not right, going about the country stealing sheep as they had done' ${ }^{69}$

Two months later, Henry Dana expressed 'in the highest terms his satisfaction of' his troopers' conduct during that and other expeditions in the western district during their first year. The Native Police 'when required for active Duty were always found ready and willing to march to any part of the country ordered to' ${ }^{70}$ Dana concluded that the experiment was succeeding: 'for the fear with which the wild blacks regard the men [of the Corps], and their knowing that now they can be followed to any place they go to, will have a good effect in preventing them from thinking that they can commit depredations with impunity' ${ }^{71}$ Since arrests were rarely made, prisoners rarely captured, just what aspect of the Native Police 'wild blacks' feared is worthy of investigation.

During 1843 Dana's Native Police were involved in six reported 'collisions' in the western district, in which an unidentified number of Aborigines were

\footnotetext{
69 French to La Trobe, 25 September 1842, VPRS-19, unit-36:item-42/1832, PROV; Critchett, pp.144-145

70 H. Dana to La Trobe, 21 November 1842, VPRS-19, unit-38:item-42/2153, PROV

71 ibid., 22 November 1842, enclosed in Gipps to Stanley, 21 March 1844, Aborigines (Australian Colonies), pp.287-288, SLV
} 
killed without trial. In reporting on this, the second year of the force under his superintendence, Dana informed La Trobe that the first 'serious collision' took place at the Grampians. Having tracked through difficult terrain for a number of days a party accused of stealing sheep, the Native Police caught up with the suspects, whom Dana ordered his troopers to shoot. After noting his surprise and pleasure at his men's willingness to follow this order, Dana added: '[f]ive more collisions after this took place, and each time property was recovered. ${ }^{\prime 72}$

At the end of the winter of 1843 Dana wrote to La Trobe reporting a 'collision' in which four Aborigines were killed by his troopers. ${ }^{73}$ A week later the incident was reported in the Port Phillip Gazette. A number of Aborigines were said to have attacked a station on the Wannon River in the western district, driving off some 180 sheep. With Dana, seven Native Police troopers tracked the suspects into the Victoria Ranges where, it was reported, the troopers fired repeatedly at the Aborigines. Seven or eight were killed outright, and more were wounded - the report estimated perhaps twenty were shot in total. Some eighty sheep were recovered alive. ${ }^{74}$

As spring dawned, Dana reported on the Native Police again having been engaged in yet another 'collision'. He and his troopers had been out patrolling along the edge of a large swamp with his men and a Mr. Edgar in the western district, near Port Fairy. The party were out searching for a lost European child when they came across sheep tracks. The Native Police followed the tracks for a short distance, where they encountered a group of Aborigines with a number of sheep in their possession. Dana reported:

\footnotetext{
72 ibid., 27 November 1843, enclosed in Gipps to Stanley, 21 March 1844, Aborigines (Australian Colonies), pp.294-295, SLV

73 ibid., 20 August 1843, VPRS-19, unit-49:item-43/2189, PROV

74 Port Phillip Gazette, 26 August 1843, p.2, SLV
} 
the natives fled into the reeds in the swamp and thinking they would be safe challenged us, I immediately ordered the Party to dismount and pursue them, the reeds however, were so tall and the swamp so wet, that we could make but little way several spears were thrown, one passed between Mr. Edgar's legs fortunately without effect: the Native was in the act of throwing another spear within ten yards of him, when he was shot by Mr. Edgar. We followed them to an Island about the middle of the swamp where we found a large camp and a number of dead sheep.

Dana ordered his troopers to retreat for the time being. They found 'the ground strued with dead sheep and others with their legs broken'. A short distance away some forty uninjured sheep were discovered. Dana sent one of his troopers to the nearest station for information. He returned about four hours later, reporting that a squatter's servant named Christopher Basset had been recently killed and upwards of 200 sheep taken from a station nearby. The Native Police made camp for the night. Dana ordered a guard over the recovered sheep.

The troopers were up again before dawn. Dana continued: 'I determined to cross the men over the swamp before daylight and if possible take some of the murderers and drive them out of the Scrub', which he 'accordingly did so'. No prisoners were taken and Dana reported that eight or nine Aborigines were shot. 'If these murderers had escaped without punishment there is no knowing when this work would stop'. The Native Police superintendent assumed the victims were among those who had killed a squatter named M'Kenzie and the servant Basset, and had taken the missing child for whom they were searching. '[T]he country they fly to, after committing these outrages is such that but few white men could follow them'. 'I trust that your Honor will not consider that I have exceeded my duty', he concluded, 'for 
following them into their strong holds, and making them feel that they shall not murder and plunder with impunity'.$^{75}$

As summer appeared on the horizon and the Native Police returned to Narre Narre Warren, the troopers were bragging about the year's successes. Thomas recorded that 'the Native Police who have been with Mr. Dana began to relate their exploits'. 'I listened attentively at length one spoke for the rest, and I cannot but say if their statement be correct (and I doubt not an iota of it) that the scene which took place in the Victoria Range, on Queen Victoria's subjects must have been disturbing to the extreme'. The assistant protector was informed how many Aborigines each individual trooper had shot dead, the total of which was seventeen. '[W]hen done he says Marnamat that (very good that) waiting for my applause'. Not wanting to promote violence but also not wanting to encourage the troopers to disobey orders, Thomas struggled with his reply. He eventually said 'poor Black fellows hungry got no Master to tell them not to steal', and further asked why the Native Police had not taken any of the suspects prisoner instead of shooting them. His informant replied: 'Captain say big one Stupid catch them very good shoot them You Black fellows no shoot them me hand cuff you and send you to Jail'.

The killing of rather than arresting Aboriginal suspects pervades the Native Police records. On passing Parker's Loddon Protectorate station on a later 1845 expedition, the troopers boasted to the assistant protector 'that they were not going to take prisoners but to shoot as many of the blacks as they could' ${ }^{76}$ Thomas further enquired if they had buried the bodies or at least inspected them. He was told '[o]h no Molocho Werrung un big one Tunanan (Dogs by \& bye big one eat them)'. Thomas suggested perhaps all who had

\footnotetext{
75 H. Dana to La Trobe, 6 September 1843, VPRS-19, unit-50:item-43/2293, PROV

76 Parker to Robinson, 4 September 1845, cited in Christie, pp.75-76
} 
been shot had not been killed, to which he was told 'oh yes no dead shoot again'.

The assistant protector sought confirmation from the Aboriginal corporal of the force that evening. 'Oh no we shot and went on', the corporal replied. He added that if Aborigines were shot but not immediately killed they invariably ran away, citing one example he had witnessed where 'a Blacks Gutts [were] shot out and the Black pulled them up shoved them in his belly and run off'. Thomas compiled what he had been told and turned from the Native Police expedition 'not wondering at such awful Murders as the unfortunate Mr. Basset but wondering that they are not more common'. He concluded that because Native Police troopers could not give a valid testimony in court, being Aboriginal, and because of 'their feeling no remorse at taking the life of a fellow but rather delight in it, especially if the Tribes be far off', the Native Police will be 'one of the greatest scourges to the Sable race' ${ }^{77}$

When Thomas forwarded his journal to the chief protector, as was usual practice, Robinson noted his comments about the Native Police and informed La Trobe. A copy of the allegations was forwarded to Henry Dana. Dana was furious. The next day the two antagonists met face to face. According to Thomas, Dana rode up to him at Narre Narre Warren and 'in the Most awful and low bred manner abused me with Oaths that I cannot insert'. Thomas stated that Dana further assured him that 'was there the least particle about me worth Kicking he would Kick me to Melbourne' ${ }^{78}$ The Native Police superintendent was ordered by La Trobe to apologise to Thomas after

\footnotetext{
77 Thomas, journal, 11 November 1843, forwarded to Robinson, 1 December 1843, VPRS-4410, unit-3, PROV; R. Howitt, pp.196-197; Ellender and Christiansen, p.91; Critchett, pp.167-170; Crawford, pp.204-206

78 Thomas to La Trobe, 3 January 1844, VPRS-19, unit-70:item-45/796, PROV
} 
the assistant protector had made an official complaint regarding his outburst. ${ }^{79}$

The day after he had verbally abused and physically threatened Thomas, Dana wrote to La Trobe opposing Thomas' claims regarding the conduct of the Native Police. Dana's defence: 'the men most probably had told him incredulous tales for the purpose of laughing at him' ${ }^{80}$ The assistant protector retorted: 'the Native Police ... were in no way backward in relating what took place, nor did the one who gave me the number killed and who killed them, in the least conceal himself'. He added that he did not make such claims in the spirit of private animosity towards Dana nor anyone else. ${ }^{81}$ Rather, drawing on his official instructions regarding his position as a colonial official, he recalled his 'unbounded duty in accordance with the instruction I received ... wherein "I am required as far as I am able by my personal exertion \& influence to protect the Aborigines from cruelty, oppression, and injustice"' .82

The Native Police superintendent further claimed that the trooper who had boasted to Thomas was not even at the 'collision' which took place in the Victoria Ranges, he was at Mt. Eckersly. He added that seventeen Aborigines could not have been killed as the Native Police had only twelve rounds of ball cartridge among them. Regarding the statement concerning an Aboriginal man's 'guts being shot out and then running away and putting them

\footnotetext{
79 H. Dana to Thomas, 5 January 1844, enclosed in Thomas to La Trobe, 8 January 1844, VPRS-19, unit-70:item-45/796, PROV; H. Dana to La Trobe, 5 January 1844, VPRS-19, unit-70:item-45/796, PROV

80 H. Dana to La Trobe, 4 January 1844, VPRS-19, unit-70:item-45/796, PROV

81 Thomas had previously faced difficulty in his role as assistant protector owing to the conduct of the Native Police, which may have led to allegations of motivations which stemmed from private animosity; Clark and Heydon, pp.53-54 \& 65-66

82 Thomas to Robinson, 4 January 1844, VPRS-19, unit-70:item-45/796, PROV
} 
in again', Dana asserted that this was 'too absurd to say anything about' other than that if Thomas had heard such a report, 'it was only as a Joke'. ${ }^{83}$

Historiographical discussion of Thomas' claims gets caught up in whether the affair constitutes a 'massacre' or not; whether the Aboriginal informants were compressing the season's numerous 'collisions' into one event; whether the trooper was exaggerating. ${ }^{84}$ Whatever label is assigned to the incident, be it 'atrocity, slaughter or extermination', ${ }^{85}$ whether the trooper was condensing events or not, Europeans here utilised Aboriginal violence to great and malign effect.

As Fels notes, Dana was officially required to explain any deaths to La Trobe in his written reports, which were then forwarded to Sydney and on to London. In cases where doubts as to the necessity of killings were raised, La Trobe had the circumstances investigated. Fels believes Dana's reports to La Trobe were unfailingly honest. She even goes so far as to propose that $\mathrm{La}$ Trobe's weekly face-to-face meetings with Dana, held every Monday he was not out on patrol, evince that Dana could not have deceived the Port Phillip superintendent. She suggests that the Native Police only killed Aborigines when all options in attempting to arrest them and march them to Melbourne - to be tried by laws which made conviction difficult - had been exhausted. 'The native police did shoot blacks, but when they did, it was regarded as a failure in the performance of their duty, and they were held accountable for their actions.' "CCollisions" between the Corps and local Aboriginal groups out in the field', Fels continues, 'were the exception to the norm. ${ }^{\prime 86}$

\footnotetext{
83 H. Dana to La Trobe, 12 January 1844, VPRS-19, unit-70:item-45/796, PROV

84 Fels, Good Men, pp.138-153 \& 138n; see also: Broome, Aboriginal Victorians, pp.81-82; Lyndall Ryan, 'Settler Massacres on the Port Phillip Frontier, 1836-1851', Journal of Australian Studies, 34:3, 2010, pp.257-273

85 Fels, Good Men, p.150

86 ibid., pp.66-67 \& 109-110
} 
While Dana was theoretically required to report in full all 'clashes' to La Trobe, however, as was so often the case with colonial officialdom, theory and practice did not always equate. ${ }^{87}$ There is good evidence to suggest Dana misled La Trobe in his reports on 'collisions'. Squatter E.M. Curr accused Dana of omitting vital details from his reports. By way of response, Dana reportedly 'laughed good-humouredly, saying that "persons unconnected with the public service know nothing of reports; indeed civilians from first to last are ill fitted to describe collisions of the sort, being apt to blurt out statements more properly held in reserve"'’.88 As was the case with Aboriginal deaths at the hands of squatters following the Myall Creek retrial, fewer tricky questions and much less paperwork arose if colonial officials just kept quiet about the punishments they enacted for Aboriginal 'crimes'. If seemingly caught misrepresenting 'collisions', however, as in the summer of 18431844, Dana could always dispute what his troopers were saying, suggesting that they were exaggerating, joking, confused, or collapsing time and events. Aboriginal evidence was, after all, not admissible in court if it ever came to that.

Understating or omitting Aboriginal deaths in official reports was certainly not unknown in Port Phillip. Parker alleged that an atrocity earlier committed by the Mounted Police had been severely understated in the official report of the incident. '[T] he number of aborigines put to death', the assistant protector asserted, 'was much greater than the sergeant who commanded the party had reported'. Contrary to what his superiors were told, 'the firing

\footnotetext{
87 'Rules and Regulations to Be Observed and Performed by the Non Commissioned Officers and Troopers of the Native Police', H. Dana to Lonsdale, 29 November 1846, VPRS-19, unit-92:item47/866, PROV; 'Native Police Standing Orders', enclosed in La Trobe to col. sec., 10 February 1843, enclosed in Gipps to Stanley, 21 March 1844, Aborigines (Australian Colonies), pp.286-295, SLV; Bridges, 'Native Police Corps', pp.114 \& 125-126

${ }^{88}$ Curr, Recollections of Squatting, pp.89-97; Critchett, pp.173-174; cf. Fels, Good Men, pp.158161
} 
continued for half an hour - and that about forty aborigines were shot - in fact all the tribe, excepting a woman and child' ${ }^{89}$

Nevertheless, as Fels herself notes, '[e]ighty page files on "collisions" are not uncommon in the various archives'.$^{90}$ Where explanations for Aboriginal deaths resulting from Native Police 'collisions' are offered in the record, which is by no means always, they are consistently explained away as due to the accused Aborigines having exhibited signs of hostility. As Thomas noted, however, resistance was regularly, and understandably, offered when strange armed and mounted men charged into an Aboriginal camp. Although the Native Police were officially not to load their weapons without the express instructions of the European commandant, and ostensibly were never to operate without the direct supervision of a European, ${ }^{91}$ this theory was not always practised. Furthermore, it did not take much for Dana to perceive danger and to thus order his troopers to load their weapons. ${ }^{92}$

In 1844, when Gippsland Commissioner of Crown Lands Charles James Tyers was told of cattle having been speared, he employed the Native Police to investigate. Tyers later informed George Dunderdale that upon tracking a number of accused Kurnai into thick scrub, two of his troopers fired without instruction. Tyers admitted that he had not seen anything to shoot at, but his troopers duly pointed out to him two mortally wounded Aboriginal suspects. 'The mercy accorded to' Aborigines, Dunderdale concluded, 'was less than Jedburgh justice: they were shot first, and not even tried afterwards'.$^{93}$ In 1845 Richard Howitt reported that upon hearing that a hut-keeper and a

${ }^{89}$ Parker to Robinson, 5 November 1839 \& 13 December 1839; Parker to Captain Smyth, 8 July 1839; Smyth to Parker, 8 July 1838 - VPRS-13172, unit-1:discs-13 \& 15-17, PROV; Ryan, 'Settler Massacres', p.269

90 Fels, Good Men, p.109

91 ibid., pp.228-232

${ }^{92}$ Critchett, p.166

93 Dunderdale, pp.265-266 
shepherd had been killed on the Edward River, '[ $t$ ]he native policemen went within twenty miles of that neighbourhood, and killed many blacks, but it is doubtful whether any of the depredators' ${ }^{94}$

Thomas acknowledged that Henry Dana had informed settlers on the Wando and Glenelg rivers that while they had permission 'in the event of any fray with the Blacks to go out', the Native Police were 'not to fire unless life was in danger'. Dana had stipulated, in fact, that his troopers 'must not be ordered to fire upon the Blacks unless resistance is made, or in the defence of lives'.$^{95}$ Thomas observed, however, that 'it cannot be denied that if a peaceful Tribe is surprised the Blacks seize their spears'. He affirmed that 'an officer might go thro' the tribes, (with one half the number as now at Mr. Dana's disposal) committing awful slaughter were he so disposed and not yet fire a single shot before a spear has been thrown'. When confronted with mounted, armed strangers - often identifiable as either enemy peoples or 'wild blacks' - suddenly arriving in their camp aggressively, Aborigines naturally moved to defend themselves. '[A] body of Mounted Men Galloping into an Encampment, however peaceable they have been before', Thomas concluded, 'is enough of itself to excite them' ${ }^{96}$

In March and April of 1843 Robinson, accompanied by two Native Police troopers and a Border Police trooper, made a journey along the Goulburn to its confluence with the Murray. 'In a region of reeds by the Loddon', the chief protector reported, 'I conferred with a large body of natives. The formidable appearance of these blacks, and the dangerous positions occupied (in a mazy and narrow path strewed with timber), alarmed one of my native

\footnotetext{
94 R. Howitt, p.197

$95 \mathrm{H}$. Dana to 'the settlers on the Wando and lower part of the Glenelg', 30 August 1843, VPRS-19, unit-70:item-45/796, PROV

96 Thomas, journal, 11 November 1843, forwarded to Robinson, 1 December 1843, VPRS-4410, unit-3, PROV; see also: Christie, p.70
} 
troopers, and he would have fired had I not prevented him. ${ }^{\prime 97}$ Native Police troopers frequently served in foreign country among either traditional enemies or traditionally feared 'wild blacks', which made them anxious, as it made those they encountered.

Aborigines pursued by the Native Police customarily met the Corps with violent resistance, and this is often given as the excuse, both by contemporary defenders and historians, for the force killing Aborigines. It must be remembered, however, that these Aboriginal victims were often in their own country, and perceived the intrusion of Aboriginal Native Police troopers as hostile action necessitating armed defence. It is unsurprising that when armed, mounted, foreign Aborigines suddenly charged into a camp Aborigines reached for their spears. Moreover, pursued Aborigines had likely heard of previous Native Police actions, and may well have felt that pre-emptive counter-attack offered their best chance of survival. And, of course, reporting that the Native Police only fired when attacked certainly saved Henry Dana and other colonial officials many bureaucratic headaches from Melbourne, Sydney, and London.

The Native Police operated in the western district every winter from 1842 to 1849.98 Broome notes that it was the Native Police who brought to an end frontier conflict in the western district during this period. The Gunditjmara were engaged in a successful guerrilla war against their invaders until, he suggests, the Native Police 'finally caught them on open ground and shot them up, thus ending the trouble' ${ }^{99}$

\footnotetext{
97 Robinson, report, 30 December 1843, enclosed in Gipps to Stanley, 21 March 1844, Aborigines (Australian Colonies), pp.279-282, SLV

98 Fels, Good Men, p.123

99 Broome, 'Struggle for Australia', p.103; Broome, Aboriginal Australians, pp.44-46
} 
Fels identifies the violent encounters of 1843 as the worst period of 'collisions' between the Native Police and Aborigines in the western district. ${ }^{100}$ The following year Henry Dana reported that the Aboriginal peoples of the western district 'appear inclined to leave off stealing sheep' owing to 'the lesson they were taught last year'. ${ }^{101}$ ' $[\mathrm{T}]$ his part of the Province is perfectly free from anything like outrages by the Natives', he added two months later. '[T]hey have shown little disposition this season to be troublesome or offensive' ${ }^{102}$ The Native Police Corps was, the superintendent announced, succeeding in its goal of utilising Aboriginal violence to suppress Aboriginal 'outrages' against Europeans.

Prior to 1844 Dana often reported his surprise at his troopers' willingness to follow orders in the heat of 'collisions'. Following the abovementioned 'first serious collision' at the Grampians in 1842, Dana had happily reported that his troopers 'showed none of that savage inclination to revenge and slaughter that many suppose is their disposition, but displayed the greatest coolness and courage, and obeyed every order I gave them with alacrity, and never attempted to strike a blow or lift a carbine unless when commanded'. ${ }^{103}$ After the 1843 'collision' at a swamp near Port Fairy, Dana recalled: 'I thought I should have some difficulty in restraining them, but they behaved uncommonly well and steady, and never fired unless absolutely necessary for their own protection and that of the party' ${ }^{104}$

Initially the Native Police operated in the western district, among language groups unknown to the Woiworung and Boonwurrung troopers. Although

\footnotetext{
100 Fels, Good Men, p.138; Critchett, pp.166-170

101 H. Dana to La Trobe, 9 August 1844, VPRS-19, unit-62:item-44/1415, PROV

102 ibid., 14 October 1844, VPRS-19, unit-64:item-44/1876, PROV

103 ibid., 6 December 1842, enclosed in La Trobe to Thomson, 10 February 1843, enclosed in Gipps to Stanley, 21 March 1844, Aborigines (Australian Colonies), pp.286-295, SLV

104 ibid., 6 September 1843, VPRS-19, unit-50:item-43/2293, PROV
} 
to begin with he had difficulty in preventing his troopers firing on these people without his ordering them to do so, overall Dana praised the Native Police conduct among those they considered 'wild blacks'. ${ }^{105}$ From 1844 the Native Police began operating in Gippsland, against their traditional enemies the Kurnai. ${ }^{106}$ 'Collisions' increased, as did Aboriginal deaths. It was in Gippsland, against their traditional enemies, that the Native Police were particularly violently effective. ${ }^{107}$

One day, in the course of lecturing his Aboriginal pupils on God having made man in His own image, Francis Edgar asked his students if they remembered the first time they had seen a white man. Jackey, a Kurnai man, informed the missionary that he did recall such an event. Upon being asked where he first saw a white man, Jackey answered: '[m]e see him down my own country, down in Gipps' Land, shoot him black fellar plaanty!' Edgar pressed Jackey for details, and told him he must not lie. Jackey explained: 'Captain Danna [sic] come down ... with him black police; shoot him black fellar there, black lubra there, black picaninni there ... shoot him pla-a-anty!' Upon being asked why Dana and the Native Police would do such a thing, Jackey told the missionary '[o]h! black fellar steal white fellar's sheep; and white fellar tell Captain Danna; and Captain Danna come down shoot him black fellar, and lubra, and picaninni plaanty!' Jackey concluded by clarifying that the Aboriginal victims had 'stolen' the sheep owing to a lack of kangaroo occasioned by Europeans: 'white fellar shoot him black fellar's kanga-

\footnotetext{
105 Fels, Good Men, pp.128-129

106 A.W. Howitt, 'On Some Australian Beliefs', pp.185-198

107 Fels, Good Men, pp.173-198; Broome, Aboriginal Victorians, pp.43-46; Broome, 'Struggle for Australia', pp.117-118; Christie, pp.71-78; Peter Gardner, 'Massacres of Aborigines in Gippsland, 1840-1850', Historian, 27, 1975, pp.19-24
} 
roo - black fellar eat him white fellar's sheep' ${ }^{108}$ Edgar followed up these claims; his own enquiries substantiated Jackey's statement. ${ }^{109}$

Fels uses perceived problems with Aboriginal use of the expression 'plenty' to cast doubt upon Aboriginal accounts of violent deaths at the hands of the Native Police. 'Plenty was a word', she suggests, 'used at the time to denote any number more than two.' ${ }^{\prime 10}$ As noted above, debating actual numbers killed and appropriate terms to describe events can detract from the realities of the frontier. Moreover, elsewhere in her reminiscences of living at the Merri Creek School during her father's time as schoolmaster, Lucy Edgar offers some light on Aboriginal use of the word 'plenty'. '[I]n most cases they added to and extended their words to an outrageous length', she observed, 'putting two or three vowels in the place of one'. '[I]f they wanted to give greater emphasis, and convey the idea of superlative of size, they added yet another vowel [for example] be-e-eg [big]'. "“Plenty," was another word they murdered in the same manner', Edgar wrote. '[I]t was always, if used in the mildest term, planty, and to express the superlative, three $a^{\prime}$ s were requisite. ${ }^{111}$ Jackey told Francis Edgar that the Native Police had shot 'pla-a-anty' of Kurnai men, women, and children.

Fels further dismissed Jackey's account of Native Police conduct in Gippsland because he named Captain Dana, whereas it was William Dana, not his elder brother Henry, who was operating in Gippsland that season. She also argues that because Jackey later joined the Native Police himself, clearly 'he was not too upset by the past actions of the Corps'. 'Perhaps', she concludes,

\footnotetext{
108 Edgar, Among the Black Boys, pp.74-75

109 Bridges, 'Native Police Corps', p.127

110 Fels, Good Men, pp.118 \& 184-185

111 Edgar, Among the Black Boys, p.3, italics in original
} 
'he exaggerated.'112 As with her discussion of the western district, Fels is concerned with whether 'massacres' rather than 'collisions' took place in Gippsland. ${ }^{113}$ The fact remains that Woiworung and Boonwurrung men were violently employed by colonial officials against their traditional Kurnai enemies.

During the summer of 1846-1847, the European populace of New South Wales was enthralled by rumours of, and subsequent searches for, a European women reportedly being held captive by Aborigines in Gippsland. ${ }^{114}$ A search party, which included a number of Aboriginal trackers, was organised under the leadership of C.J. de Villiers, the former Native Police superintendent. In November 1846 William Dana was directed by his elder brother to 'proceed to Gippsland with your Division of Native Police', in order to aid Gippsland Commissioner of Crown Lands C.J. Tyers 'in ascertain[ing] if the white woman supposed to be with the Natives exists'. If she was found to be more than a rumour, Henry Dana told his brother, 'every exertion must be made to rescue her' ${ }^{\prime}{ }^{115}$

On the evening of 20 January 1847 two of de Villiers' Aboriginal trackers arrived in Melbourne with a despatch from him relating to the search for the 'captive white woman' and the involvement of the Native Police. The Melbourne Argus reported from de Villiers' despatch: 'the negotiations for the recovery of the white female ... have been broken off, and the objects of the expedition for the time frustrated by an untoward collision between the blacks

112 Fels, Good Men, p.185

113 ibid., pp.173-198

114 Kate Darian-Smith, 'The White Woman of Gippsland: a Frontier Myth', in Darian-Smith et al. (eds.), Captured Lives: Australian Captivity Narratives, London:1993, pp.14-34; Kate Darian-Smith, 'Marking Capture: White Women Captives in Australia', in Joy Damousi and Katherine Ellinghaus (eds.), Citizenship, Women and Social Justice: International Historical Perspectives, Melbourne:1999, pp.71-78

115 H. Dana to W. Dana, 21 November 1846, VPRS-19, unit-92:item-47/866, PROV 
and the Native Police, under Mr. Dana jun., which seems to have been attended with a considerable loss on the part of the blacks, and which, according to Mr. De Villiers' statement, Mr. Dana had suppressed all mention of' ${ }^{116}$

In the following issue of the newspaper de Villiers' despatch was reported in full. On 13 December 1846 de Villiers heard that the missing woman was on the Snowy River. While on their way to investigate, on the evening of $20 \mathrm{De}-$ cember de Villiers' party came within three miles of the Native Police camp. Earlier in the day they had heard gunshots. The following afternoon the party arrived in Dana's camp, 'an hour previous to that', de Villiers reported, 'firing was heard again'. William Dana informed de Villiers that the Native Police had 'just arrived from the islands situated on the Snowy River, and had surrounded or rushed several camps of natives, and could discover no white woman'. De Villiers noted that Dana had with him five Aboriginal prisoners - a man, a woman, and three children: '[f]rom appearances, I thought all was not right'. De Villiers requested his Aboriginal trackers be able to question the prisoners, who were subsequently taken to his camp. There 'they appeared to be very mournful, and gave my blacks to understand that blackfellow and white fellow belonging to Narran, (the native name for the police station), had been shooting the Snowy River blacks'.

The following day de Villiers announced his party were departing for the Snowy River. In response 'Mr. Dana appeared very anxious to give me directions about going up the Snowy River, and said I must not take the right hand branch, as it was only navigable a very short distance'. That afternoon, de Villiers 'proceeded up the river, taking the same direction Mr. Dana endeavoured to persuade me not' to take. About one mile up the party discovered the mutilated body of a dead Aboriginal man with what appeared to be

116 Melbourne Argus, 22 January 1847, p.2 
gunshot wounds. He was informed that the body was one of five shot by 'Narran black and white fellow' and that the victims had offered no resistance or aggression. Members of the party also 'found the remains of some broken spears and a shield', and a Native Police trooper's 'carbine broken in half by the lock, upon which appeared the corroded marks of blood, also a quantity of blackfellow's hair in several parts of the lock, leaving no doubt how the piece was broken'. De Villiers was most concerned that William Dana and his troopers had since for six days resided at Tyers' station, yet 'not a syllable had been uttered relative' to the killings. He added that the Kurnai only 'frequent the most inaccessible parts [of Gippsland], in consequence of being so constantly hunted by the native police and settlers' ${ }^{117}$

Two years after he had assisted in establishing the fourth Native Police Corps, Thomas summed up his views: 'Bl[ac]ks are a cruel lot to their Enemies as they consider all with whom they have not acquaintance, under such circumstances the Native Police in the absence of moral improvement are a dangerous body'.118 Following the disbandment of the Corps, James Bonwick noted: '[m]any saw with apprehension the arming of one portion of natives against the others, knowing how the deadly animosity and revenge of a tribe may thus be gratified under the shelter of the law.'119 In the second edition of his history, Bonwick added that more than fifty Kurnai were 'coolly murdered' by the Native Police in their search for 'a supposed white female

\footnotetext{
117 De Villiers to Cavenagh, 1 January 1847, Melbourne Argus, 26 January 1847, p.4; see also: Peter Gardner, 'The Journals of de Villiers and Warman: the Expedition to Recover the Captive White Woman', VHM, 50:2, 1979 ,pp.89-97; Crawford, pp.207-208; W.J. Cuthill, 'The White Woman with the Blacks in Gipps' Land', VHM, 31:121, 1961, pp.7-25

118 Thomas, journal, 13 June 1844, cited in Nance, p.540

119 James Bonwick, William Buckley, the Wild White Man, and his Port Phillip Black Friends, Melbourne:1856, p.93
} 
captive'. 'Our black police were', he concluded, 'horrible instruments of colonial law.' ${ }^{120}$

Among their own people and those with whom their language group held good relations, Native Police troopers were found to be relatively ineffective in the attempted colonial utilisation of Aboriginal violence. In the western district, among unknown and traditionally feared 'wild blacks', the Native Police were found to be effective when ordered to commit violence. Among their traditional Kurnai enemies, the Woiworung and Boonwurrung troopers were particularly violently effective in promoting British colonisation, both within and separate from their official policing duties.

In 1838 Threlkeld was asked his opinion of the proposed employment of Aborigines as Native Police. Among his concerns at the proposal, the missionary listed: ' $[\mathrm{t}]$ he danger of teaching barbarians the use of firearms before they have Christian principles to guide their consciences in the just use thereof ... [that] they will have means and opportunity to use violence to British females, or women of other tribes ... [and] from the nature of their employment, which also affords many opportunities for intoxication'. ${ }^{121}$ Following the Native Police killings which accompanied the search for the 'captive white woman', Kurnai groups were forced to surrender a number of their women to the Boonwurrung troopers. 'The absurd story of the White Lady in captivity against the savages of Gipps Land and which led to extraordinary and fatal results against that section of aborigines', Robinson wrote in his 1848 annual report, 'has subsequently induced the Gipps Land

\footnotetext{
120 James Bonwick, The Wild White Man and the Blacks of Victoria [1856], second edition Melbourne: 1863, p.74

${ }^{121}$ Threlkeld to Gipps, 7 May 1838, HRV2A, pp.247-249
} 
natives to surrender a number of their females to the Boomerongs [Boonwurrung] Western Port Tribes' ${ }^{122}$

Some troopers later used their policing skills and experiences for internecine violence. Thomas recalled of one Native Police trooper, Pee-rup, that after leaving the force he was rarely seen in the environs of Melbourne, instead 'going to and fro with others purchasing or stealing Gippsland lubras'. Peerup was, along with two other Aboriginal men, killed by Kurnai men on the Mitchell River in May 1850. ${ }^{123}$

Dunderdale reported on Native Police conduct outside their official duties. He noted that there was no doubt that the troopers drank rum, they could not always be supervised, and 'it was not always possible to discover in what manner they spent their leisure hours'. What was discovered of their conduct during their leisure time, he asserted, showed that they 'considered themselves as living among hostile tribes, in respect of whom they had a double duty to perform, viz., to track cattle spearers at the order of their chief, and on their own account to shoot as many of their enemies as they could conveniently approach'. Dunderdale further related an account in which Tyers, out entertaining a party of Europeans, accidently came across 'a large pile of corpses of the natives shot by his own black troopers' hidden beneath some deadwood. The commissioner for crown lands directed his Native Police troopers to burn the evidence - 'to make it a holocaust'. ${ }^{124}$

Native police troopers thus engaged in violence outside of their policing duties. ${ }^{125}$ In November 1845 Parker reported that five Aboriginal men, two of

\footnotetext{
122 Robinson, 'Annual Report', 1 January 1849, VPRS-2895P, unit-1, PROV

123 Thomas, 'Brief Account', p.408

124 Dunderdale, p.267

125 see also: Fels, Good Men, pp.101-104 \& 157
} 
them off-duty Native Police troopers, had killed an Aboriginal man on the Loddon the previous month. ${ }^{126}$ The following month Thomas reported that two intoxicated off-duty troopers had run around his encampment threatening Aborigines with their guns. '[G]et drunk they will', the assistant protector complained, 'and when in that state are like maniacs, nor is any one safe black or white while they are in this state' ${ }^{127}$ Billibellary, Thomas lamented, had 'lived to see them [his people] become drunkards, and refractory to their own laws'. ${ }^{128}$ It could be sardonically suggested that this was the 'civilising' aim of the Corps achieved, but the sad fact remains that many Native Police troopers died drunkards.

In March 1844 Governor Gipps reported to Lord Stanley on the 'civilising' potential of the Corps. The experiment 'strongly confirm[s] the opinion I have long entertained', Gipps enthused, 'that in the civilization of savages, military discipline, or something nearly approaching it, may advantageously be employed'. ${ }^{129}$ The function of the Native Police as a 'civilising' force for its members is an interesting commentary on 'civilisation': one could become 'civilised' by shooting other Aborigines like 'civilised' Europeans did. Upon the Corps disbandment, La Trobe concluded that the Native Police was the only example of success among the many schemes set on foot to raise the aboriginal native in this quarter of New Holland above his natural level' ${ }^{130}$

In a fit of jealousy on the parade ground at Narre Narre Warren, in January 1851 William Walsh shot William Dana. As examined in chapter three, just

\footnotetext{
126 Parker to Robinson, 12 November 1845, VPRS-11, item 45/235, PROV

127 Thomas to Robinson, 10 December 1845, VPRS-11, item 45/621, PROV

128 Thomas, 'Brief Account', p.405; on Native Police drunkenness see: Bridges, 'Native Police Corps', pp.134-135; Broome, Aboriginal Australians, p.55; Blaskett, pp.225, 297 \& 342-350; Crawford, pp. $219-220$

129 Gipps to Stanley, 21 March 1844, Aborigines (Australian Colonies), pp.283-295, SLV

130 La Trobe to Sir J. Pakington, 22 January 1853, in Bride (ed.), Letters from Victorian Pioneers, p.441
} 
how 'civilised' those doing the 'civilising' were warrants investigation. Walsh was married to a reportedly 'extremely pretty' Collingwood woman named Isabella. In early-January 1851, upon suspecting William Dana of exchanging letters with his wife, and also of improper conduct with his sister Sophia, Henry Dana's wife (whom William Dana later married, four years after his brother's death), Walsh confronted his fellow Native Police sergeant, and the matter appeared resolved. Six days later, however, as Walsh and his wife rode into camp following a visit to Melbourne, Dana moved to help Isabella down from her horse - an action which proved too much for the suspicious Walsh, who shot Dana in the chest. Dana survived, reportedly carrying the bullet in his chest until his death fifteen years later.

During Walsh's trial, in the course of attempting to substantiate a defence of insanity, some telling anecdotes about the European superiors of the Native Police Corps were aired. Walsh was reported to have one time refused an offer of shelter at an inn, preferring instead to sleep in the rain, under a tree, with the bridles of his two horses attached to his feet. Another account told that on a different occasion both Walsh and William Dana had been drinking heavily before being confronted by the near biblical predicament of there being only one room left at the inn for the two men. The Native Police sergeants tossed a coin, but not to see who would get the room. Rather, as it was dark, Dana and Walsh gambled to determine who should first hold a candle while the other shot at him. If the first missed, it was his turn to hold the candle while the other shot. Wobbling from the alcohol they had imbibed neither man hit, and the duel ended with both sleeping on the ground outside. Just what the Native Police troopers, whom Dana and Walsh were 'civilising', thought of this behaviour went unrecorded, but presumably it 
affected their notions of the 'civilisation' they were being encouraged to emulate. ${ }^{131}$

Upon the discovery of small amounts of gold in Port Phillip in 1849 and the subsequent gold-rush which began in 1851, Native Police operations shifted towards policing on the goldfields. On 24 November 1852 Henry Dana died, aged thirty-five, as a result of pneumonia contracted whilst on duty searching for bushrangers. ${ }^{132}$ Following Dana's death, the Port Phillip Native Police Corps, the largest policing body in the district, quickly slid into dissolution in early-1853, although Aborigines continued to be employed as trackers. ${ }^{133}$ La Trobe wrote:

[t]he marked success [of the force] ... gave confidence to the settler, removed the pretexts under which he would feel justified in taking redress into his own hands, and left no excuse for the vindictive reprisals which have been a blot upon the early years of the settlement. The native, on his side, soon saw that in yielding to his natural aggressive impulses he would be opposed to those who were not only his equals in savage cunning and endowment, but his superiors by alliance with Europeans. ${ }^{134}$

The Port Phillip superintendent thus believed the Native Police Corps successfully reduced European-Aboriginal violence. It did so, however, through the utilisation of Aboriginal violence.

${ }^{131}$ William Dana had, on another occasion, been so intoxicated on a return from Melbourne that he was unable to keep his saddle, and his horse 'spilt him on the road and galloped away in disgust'; Fels, Good Men, pp.80 \& 202-206; O'Sullivan, pp.48-49; Sadleir, 'Early Days of the Victorian Police', p.77; Christie, p.77; L.J. Blake, 'The Native Police Corps', Gipps-Land Gate, 1:3-4, 1971, pp.42-45 \& 56-63

132 [Melbourne] Argus, 30 November 1852, p.8; Colonial Times, 3 December 1852, p.2

133 Fels rightly draws attention to Aboriginal agency in the dissolution of the Corps, which was evident prior to Dana's death; Fels, Good Men, pp.199-202; C.E. Sayers, 'Henry Edward Pulteney Dana', in Bride (ed.), Letters from Victorian Pioneers, p.438; John Sadleir, Recollections of a Victorian Police Officer [1913], Melbourne:1973, pp.50-51; O’Sullivan, p.7

134 La Trobe to Pakington, 22 January 1853, in Bride (ed.), Letters from Victorian Pioneers, p.440 
Nance estimated that 125 Aborigines died at the hands of the Native Police. This is in addition to the some 200 Aborigines she estimates to have died at the hands of Aborigines not enlisted in the force between first contact and 1851. ${ }^{135}$ Barwick lists the 'punitive expeditions of police' among the causes of 'excessive mortality' among Aboriginal peoples of Port Phillip during this period. ${ }^{136}$

This investigation rejects Fels' assertion that '[t]he evidence hints at gentlemenly code of behaviour rather than an ethic of bloodthirstiness' within the Native Police. ${ }^{137}$ Instead, it is proposed that colonial officials wilfully exploited traditional Aboriginal inter-language group hostilities in the colonisation of Port Phillip - an exploitation which Native troopers relished; they were not victims.

Beginning in 1848, colonial officials began recruiting Aboriginal men of the Port Phillip District to be employed on the New South Wales frontier north of the Tweed River, in what became the colony of Queensland in $1859 .{ }^{138}$ Of the Port Phillip Native Police and the Queensland Native Police, Christie asserts the operation of the two forces and the damage they did were very similar'. ${ }^{139}$ The Queensland Native Police were also 'brutally effective'. ${ }^{140}$ As

135 Nance, pp.533, $540 \& 552$

136 Barwick, 'Changes in the Aboriginal Population of Victoria', p.288

137 Fels, Good Men, p.121

138 Christie, p.77; Foxcroft, p.115; Jessie Mitchell, "The Gomorrah of the Southern Seas": Population, Separation and Race in Early Colonial Queensland', History Australia, 6:3, 2009, pp.69.3 \& 69.969.10; Presland, For God's Sake Send in the Trackers, p.16

${ }^{139}$ Christie, p.77

140 Ann McGrath, 'A National Story', in McGrath (ed.), Contested Ground, p.18; Jonathan Richards, The Secret War: a True History of Queensland's Native Police, Brisbane:2008, passim; Mark Copland, Jonathan Richards, and Andrew Walker, One Hour More Daylight: a Historical Overview of Aboriginal Dispossession in Southern and Southwest Queensland, Toowoomba:2006, pp.33 \& 38-73; Raymond Evans, A History of Queensland, Cambridge:2007, pp.71-72, 94-97 \& 137-138; Hall, pp.75-95; Alan J. Hillier, 'The Native Police under Scrutiny', Journal of the Royal Historical Society of Queensland, 15:6, 1994, pp.279-293; Reynolds, With the White People, pp.41-84; see also: Amanda Nettelbeck and 
the frontier moved north, so too did the utilisation of Aboriginal violence.

Robert Foster, In the Name of the Law: William Willshire and the Policing of the Australian Frontier, Adelaide:2007, passim 


\section{Chapter Six \\ '[W]hose aid saved the colony': Kūpapa, Māori Police, te Ātiawa feud, and the Utilisation of Māori Violence}

The British Crown officially went to war against various Māori groups intermittently between 1845 and 1872. These conflicts, known as the New Zealand Wars, arose when the British attempted to convert nominal sovereignty into substantive sovereignty and were opposed by various iwi and hapū. The New Zealand Wars can be divided into five: the Northern War, fought in the vicinity of the Bay of Islands between 1845 and 1846; the Southern Wars, fought in the lower North Island between 1846 and 1847; the Taranaki Wars from 1860; the Waikato War, including the Tauranga conflict, 18631864; and the later campaigns against Titokowaru (1868-1869) and Te Kooti (1868-1872).

The te reo Māori term 'kūpapa' - a verb meaning, depending on the context in which it is applied, to lie flat, to stoop down, to remain neutral, or to collaborate - was employed from the Waikato War onwards as a noun (sometimes capitalised) to identify Māori who fought in the New Zealand Wars on the side of the British. Sometimes it was also used to denote 'neutral' Māori: 'one who is sitting still, taking no part with either side'. ${ }^{1}$ Some Māori object to use of the term kūpapa as applied to Māori who supported the Crown; some deny it was ever used historically by Māori themselves. Europeans contemporaneously identified kūpapa as 'friendlies', 'allies', or 'Queenites', however these terms fail to adequately account for Māori agency in fighting a common enemy alongside the Crown, often for reasons separate from

\footnotetext{
1 R.I.M. Burnett, 'Kupapas', JPS, 74:2, 1965, pp.227-230; Monty Soutar, 'Kūpapa: a Shift in Meaning', He Pukenga Kōrero: a Journal of Maori Studies, 6:2, 2001, pp.35-39; Robert Burrows, 1 May 1845, Extracts from a Diary kept by the Rev. R. Burrows during Heke's War in the North in 1845, Auckland:1886, p.24; David Green, 'Kupapa', in McGibbon (ed.), pp.271-272
} 
those of the British. Although not used in this sense until after 1863, the noun kūpapa is, therefore, here employed as a useful umbrella-term to denote Māori who either formed an alliance with the Crown, or if not directly allied to the Crown, who fought against other Māori groups with whom the British were concurrently at war. As with the Port Phillip Native Police, labelling kūpapa Māori 'traitors' assumes a pan-Māori homogeneity which simply did not exist prior at least until the Kingitanga movement. ${ }^{2}$

While kūpapa became increasingly important in the New Zealand Wars, here the focus is directed at the first major British-Māori conflict: the Northern War, which Sinclair has described as 'in many ways a rehearsal for the more extensive wars of the [eighteen] sixties'. ${ }^{3}$ Attention is specifically drawn to those Ngāpuhi hapū, led principally by Tāmati Wāka Nene of the Ngāti Hao hapū of the Hokianga, who fought alongside the British against other, 'rebel' Māori - fellow Ngāpuhi - led by Hōne Heke Pōkai of the Ngāti Rahiri hapū, and Te Ruki Kawiti of the Ngāti Hine hapū.

Many Māori were also employed, both officially and unofficially, as police on the nineteenth-century New Zealand frontier, from 1815 to 1887. Māori constables who served up to the middle of the nineteenth century, who were recruited to police both Māori and Pākehā, are also examined in this chapter to further explore the utilisation of Māori violence in the colonisation of New Zealand. The chapter closes with a brief examination of te Ātiawa feud of the 1850s, during which settlers and colonial officials utilised Māori violence in seeking to buy land in Taranaki.

\footnotetext{
2 Some kūpapa were later labelled 'traitors' by other Māori; Thomas McDonnell, 'A Maori History: Being a Native Account of the Pakeha-Maori Wars in New Zealand', in T.W. Gudgeon, The Defenders of New Zealand: Being a Short Biography of Colonists who Distinguished Themselves in Upholding Her Majesty's Supremacy in these Islands, Auckland:1887, pp.518 \& 523; Belich, Making Peoples, p.246

${ }^{3}$ Sinclair, Origins, p.64
} 
Māori who fought to sell land, Māori police, and Māori who allied with, or at least fought a common enemy alongside the British in the 1840s are examined in this chapter to analyse the colonial utilisation of indigenous violence in New Zealand. This utilisation was not, however, one-sided exploitation Māori who sided with the Crown did to for their own purpose, and did so on their own terms. In reviewing Belich's New Zealand Wars, G.V. Butterworth asserts that 'Maori motivations and organisation do need to be investigated'. ${ }^{4}$ While he is here referring to 'rebel' Māori intent, the point applies equally to kūpapa, to Māori police, and to 'land-selling' Māori. This is a history of multiple motivations and of mutual utilisations.

In this chapter it is argued that as was the case in New South Wales, the Crown sought to utilise indigenous violence in the colonisation of New Zealand to a greater degree than is generally acknowledged. This utilisation of Māori violence was multifarious, with inter-iwi/hapū warfare, policing, and intra-iwi/hapū conflict all exploited by the Crown. It is further argued here that the utilisation of Māori violence in the promotion of colonisation relied heavily on Māori agency, with Māori individuals and groups allying with the Crown in seeking to further their hapū or iwi aspirations. While the colonisation of New Zealand depended on the utilisation of Māori violence, Māori 'allies' saw the purpose of alliances with the Crown as means for promoting their hapū or iwi objectives. Kūpapa, therefore, utilised European-Māori violence at the same time as their violence was being utilised by the Crown.

${ }^{4}$ G.V. Butterworth, '[Review of] Belich, James: The New Zealand Wars', JPS, 99:2, 1990, p.214 
In early-1828, knowing his death to be approaching, Hōne Heke's uncle and later father-in-law, Hongi Hika, is said to have warned of the coming of the red-coated Pākehā soldiers. '[I]f ever there should land on this shore a people who wear red garments ... and who always have arms in their hands ... these are a people called soldiers, a dangerous people, whose only occupation is war'. 'When you see them', Hongi reputedly cautioned, 'make war against them.' The tale may be apocryphal, but Heke, who declared to the Pākehā-Māori Jacky Marmon that 'the spirit of his father-in-law Hongi was in him', certainly did make war against the kotiwhero, the Pākehā redcoats. ${ }^{5}$

During his first visit to the Bay of Islands, on Christmas Day 1814 - a Sunday, the day the gospel was first preached in New Zealand - Marsden noted in his journal that he was cheered by the sight of the 'English flag flying'. Marsden considered this display 'the signal for the dawn of civilization, liberty, and religion in that dark and benighted land' New Zealand. 'I never viewed the British colours with more gratification', he wrote, 'and flattered myself that they would never be removed till the natives of that island enjoyed all the happiness of British subjects.' ${ }^{6}$ Twenty-five years later British sovereignty was declared over New Zealand and the Union Jack flag continued to wave in the Bay of Islands breeze. After only four years of being British subjects, however, said happiness was wearing thin, and the British colours which once flew atop Maiki Hill overlooking Kororāreka lay in the mud, felled by dissatisfied Māori.

\footnotetext{
${ }^{5}$ F.E. Maning, History of the War in the North of New Zealand against the Chief Heke, in the Year 1845, told by an Old Chief of the Ngapuhi Tribe, Auckland:1862, pp.1 \& 7-8; John Marmon, 'The Life and Adventures of John Marmon, the Hokianga Pakeha Maori; or, Seventy-Five Years in New Zealand', Otago Witness, 25 March-15 April 1882, 25 March 1882, p.25; Rogers, Te Wiremu, p.201; Buick, New Zealand's First War, pp.28-29 \& 56

6 Marsden, 25 December 1814, Letters and Journals, p.93
} 
By 1844, four years after he had signed te Tiriti o Waitangi, Heke and his people had become upset at the changing nature of Māori-Pākehā interaction in northern New Zealand. Heke was incensed at the shift of British focus, from the Bay of Islands south to the new Pākehā capital Auckland. ${ }^{7}$ He was also distressed by an economic downturn occasioned by the introduction of British customs duties and shipping levies, the effects of which were compounded by economic depression in the Tasman world. The Ngāpuhi rangatira was further angered by an attempted government ban on the felling of kauri.

Furthermore, and perhaps most importantly, he remained infuriated by the assault on rangatiratanga occasioned by the British hanging of Maketu, in March 1842, for the killing of a Pākehā family and the son of a fellow Ngāpuhi rangatira. That Maketu had killed a Māori boy as well as a number of Pākeha is sometimes overlooked, but was a key factor in Heke's anger. Heke was incensed at the European refusal to allow Māori to police Māori matters - in this case the killing of a Māori boy by Maketu - free from Pākehā interference: an attack on rangatiratanga. Governor FitzRoy added that Heke was upset that it was the Queen, not Māori rangatira, who was prayed for in church at Waitmate: 'he asked, indignantly, why the Queen of England was exulted to the skies, and the chiefs of New Zealand were trodden under foot' ${ }^{8}$ As utu for these grievances, Heke had the flagstaff which overlooked Kororāreka felled on 8 July 1844 - a symbolic gesture of defiance aimed at the Crown, but not at Pākehā settlers. The flagstaff, originally a gift

\footnotetext{
${ }^{7}$ On the transfer of the capital from Russell to Auckland see: Terry, pp.28-46; Burrows, Extracts, p.5; Buick, New Zealand's First War, pp.10-13

${ }^{8}$ FitzRoy, Remarks, p.12; Burrows, 4 March \& 26 May 1845, Extracts, pp.9-10 \& 32; William Fox, The War in New Zealand [1886], Christchurch:1973, pp.19-20; Henry Williams, Plain Facts Relative to the Late War in the Northern District of New Zealand, William Williams (ed.), Auckland:1847, pp.8-17 \& 31-34; Rutherford, Heke's Rebellion, pp.12-13, 22-23 \& 26-40; Clarke (junior), Notes, pp.41-43; Buick, New Zealand's First War, pp.2n \& 23-26; Clarke, Final Report, p.4; Wards, Shadow, pp.54-55; Ward, Show of Justice, pp.53-55; Adams, Fatal Necessity, p.218
} 
to the governor from Heke himself, was intended to fly a Māori flag, but had instead been flying the Union Jack.

Concerned at this assault on British sovereignty and fearing widespread Māori rebellion, FitzRoy dispatched ships from Auckland to both New South Wales and Van Diemen's Land seeking reinforcements. In the second week of August 1844 the aptly named barque Sydney arrived with 160 troops. Heke felled the replacement flagstaff on 10 January 1845. And when 'another of more lofty pretensions' was swiftly erected, he severed it a third time eight days later. ${ }^{9}$

After Heke had thrice felled the flagstaff at Kororāreka - that phallic symbol of British interference in Māori rangatiratanga - the governor stationed his small military detachment and his recently-arrived sole warship at the small Bay of Islands township. Heke's challenge to British sovereignty would not be ignored. The governor again sent across the Tasman Sea for reinforcements, which arrived in Auckland on 20 March 1845. Meanwhile, despite its recent iron reinforcing and military guard, on 11 March Heke severed the flagstaff a fourth time. At the same time, Kororāreka, that 'unblushing metropolis of an oddly licentious community' was sacked and burned - 'purified by fire' in the words of one historian. The Pākehā inhabitants of the smouldering township fled to Auckland. ${ }^{10}$

\footnotetext{
${ }^{9}$ FitzRoy, Remarks, p.14; Burrows, Extracts, pp.7-8; Rutherford, Heke's Rebellion, p.11; Buick, New Zealand's First War, pp.14-18

10 Rutherford, Heke's Rebellion, pp.5 \& 36; Clarke to McLean, 31 March 1845, MS-Papers-00320215, Object\#1000767, ATL; New Zealander, 19 November 1845, p.1; FitzRoy, Remarks, pp.14 \& 2934; Burrows, Extracts, p.3; Marmon, Otago Witness, 15 April 1882, p.26; Maning, History of the War, pp.5-10; McDonnell, pp.505-507; Buick, New Zealand's First War, pp.55-83; Belich, New Zealand Wars, pp.30-41; Belich, Making Peoples, pp.206-207; Wards, Shadow, pp.54-55, 95-128 \& 178; M. King, Penguin History, p.184; Rogers, Te Wiremu, pp.197-217
} 
Heke's repeated felling of the flagstaff caused the governor to fear large-scale Māori-British conflict. In February 1845, worried that war was rapidly approaching in the north, FitzRoy sent Sub-Protector of Aborigines George Clarke (junior), who had grown up in the Bay of Islands, to visit various Ngāpuhi rangatira to assess the situation. The sub-protector for the northern district, Henry Tacy Kemp, had fled the district at the first sign of trouble, much to the annoyance of FitzRoy - 'though he would not blame him'. FitzRoy's action was prompted by a wish for a 'Government agent, who might at least rally our Maori allies ... to hold him [Heke] in the North'.

Clarke (junior) reported back to Auckland on those hapū who were likely to support the Crown, and those who were likely to support Heke. He exclaimed that 'Heke, Kawiti, and half a dozen other Chiefs were determined this time to fight', and recalled, drawing perhaps on the benefit of hindsight, that they intended to again 'destroy the flag-staff'. He further noted: 'Nene, Patuone, Taewai, Repa and all the Hokianga branch of the tribe would support us', however, 'Pomare, Tareha, and Mauparaoa, the resident Chiefs in the Bay itself, and Ruhe, at Waimate, would be doubtful, sympathising indeed with Heke'.11

Heke's fourth felling of the flagstaff and the accompanying sacking of Kororāreka was reported to Major Cyprian Bridge, commander of the 58th Regiment based at Parramatta, as: 'the total destruction of one of the principal settlements in the Bay of Islands and the loss of 13 Europeans killed and 19 wounded'. ${ }^{12}$ Across the Tasman Sea the Auckland Chronicle reported Heke's actions in a manner most frightening for Pākehā. According to a correspondent for the newspaper, the tauā:

\footnotetext{
${ }^{11}$ Clarke (junior), Notes, pp.70-73; FitzRoy, Remarks, p.47

12 Cyprian Bridge, 'Journal of an Expedition to New Zealand', 4 April 1845, MS-0257, ATL
} 
brandished their tomahawks in the faces of the white people, indecently treated some white females, and exposed their persons; they ... proceeded to the flag staff, which they deliberately cut down, purposely with the intention of insulting the government, and expressing their contempt of British authority. During the whole of these riotous proceedings they were headed by Heke who insulted the Europeans in every possible way.

Referring to the 1843 Wairau incident, in which 22 Pākehā were killed when an armed party of New Zealand Company settlers led by police attacked a group of Ngāti Toa, Heke had, the report continued, 'repeatedly said "he did not see why [Te] Rauparaha should have all the fun of killing the white people," for he "should like to kill a few of them himself".'. ${ }^{13}$ The claim that Heke's toa 'indecently treated' Pākehā women and 'exposed their persons' appears to have stemmed from the warriors striping off their clothing to perform a haka, 'whereupon the ladies present threw their skirts over their heads and ran off with muffled shrieks'.14

Upon arriving in New Zealand, Major Bridge 'heard we were anxiously expected - as the town of Auckland was threatened to be attacked by a chief by the name of Kawiti'. ${ }^{15}$ More important than the various perceived threats to Auckland, however, Heke's toa had, in March 1845, attacked and sacked Kororāreka, New Zealand's fifth largest town - a settlement which was at the time defended by the might of the British Army and the Royal Navy. This humiliating defeat - which included the felling of the well-guarded flagstaff, the symbol of asserted British sovereignty, a fourth time - would not be tolerated by the British. War was declared in the north.

\footnotetext{
${ }^{13}$ Auckland Chronicle, 11 July 1844, cited in Wilson, From Hongi, p.258

${ }^{14}$ Rutherford, Heke's Rebellion, p.28

15 Bridge, journal, 22 April 1845, MS-0257, ATL
} 
Ian Wards began his chapter 'Captain FitzRoy versus Hone Heke' by asserting that the Northern War 'was unique in the conflicts with the Maoris in that it was almost entirely between Maori and government'. Kūpapa participation in the war was, however, distinctly separate from Crown participation. The conflict, therefore, cannot be properly divided into a two-sided affair - Crown versus Māori. Wards went on to acknowledge kūpapa involvement, identifying their participation as 'the first civil, as distinct from tribal, war between Maori and Maori, for the Maoris took sides for entirely different reasons than those which had prompted the old tribal conflagrations'. ${ }^{16}$ Earlier, Rutherford asserted that '[t]he war was not only a war of Pakeha versus Maori, it was also a civil war among the Maoris themselves, with one half of the Maoris fighting loyally for the Queen.' ${ }^{17}$

Kūpapa participation in the Northern War was not based on entirely different motives than previous inter-hapū or inter-iwi conflicts. Rather, Māori violence in the Northern War should be considered as a modified continuation of internecine violence, not as distinctly separate from earlier clashes. Numerous accounts suggest that Wāke Nene opposed Heke in part because Heke had killed an elder relation of his, Te Tihi, and had furthered the insult by consuming the dead man's eyes. ${ }^{18}$ Wards himself noted that Heke explained to FitzRoy that Wāka Nene and his toa were fighting because of the death of an ancestor, Hao. ${ }^{19}$ As Belich observes, the skirmishes fought between Heke and Kawiti on the one side, and Wāka Nene on the other, were 'a war within a war ... fought for different ends'. ${ }^{20}$

\footnotetext{
${ }^{16}$ Wards, Shadow, p.95, italics in original

17 Rutherford, Heke's Rebellion, p.42

18 Maning, History of the War, pp.10-11; S.P. Smith, Maori Wars, pp.52-54; Obeyesekere, Cannibal Talk, p.109

19 Heke to FitzRoy, 29 August 1845, cited in Wards, Shadow, p.101

20 Belich, New Zealand Wars, pp.34-36
} 
Küpapa did not fight the same foe as the red-coated British soldiers fought 'because red was their favourite colour'. Nor did they fight the British because they 'were particularly intrigued by the bugle calls which regulated the troops' movements' - both suggestions offered in a 1979 history of the Northern War. Earlier that same decade another historian proposed that Kawiti's decision to join Heke in fighting against the British 'stemmed solely from an old-fashioned Maori desire to test the fighting worth of the British soldiers', and that it was 'equally clear that many of his followers were only motivated by dreams of loot'. ${ }^{21}$ More recently, and more generally, it has been argued that 'the tragedy of the land wars was that Māori converts were forced to choose sides, along tribal lines as kūpapa ... fighting for the Queen, or "rebels" fighting for the Māori King and their land'.22

Contemporaneously, Europeans largely believed kūpapa supported the British because they were pro-Crown. Prior to the battle at Ruapekapeka a writer for the New Zealander declared: '[i]t is but justice to record the consistent, persevering loyalty of our Native ally Nene, (or Thomas Walker), whose courage and unflinching adherence to the British Flag, is deserving of not only the highest praise, but of some substantial acknowledgement of the estimation in which his services are regarded by the Representative of the Queen of Great Britain'. ${ }^{23}$

Māori allegiances during the New Zealand Wars, related to the labyrinth of whakapapa as it was, were extremely complex. Clarke (junior) remembered encountering during the Northern War 'wild larrikin lads about Waimate, as

\footnotetext{
21 Michael Barthorp, To Face the Daring Maoris: Soldiers' Impressions of the First Maori War, 1845-47, London:1979, p.45; Tom Gibson, The Maori Wars: the British Army in New Zealand, 18401872, London:1974, pp.22 \& 28; Buick, New Zealand's First War, p.16n

${ }^{22}$ Newman, p.317, emphasis added

${ }^{23}$ New Zealander, 19 November 1845, p.1
} 
nearly related by blood to one side as to the other, and who of course did not care a rush for the cause of battle, but they looked upon a scrimmage much as we do at a game of football'. He recalled his amusement at witnessing 'a group of four young scamps sitting round their evening fire, making up their minds which side they would severally take in the skirmish of the morrow'. That these young men borrowed ammunition from one another before going their separate ways - some to Heke's toa, others to Wāka Nene's - then would later return to discuss their adventures, greatly surprised the subprotector. ${ }^{24}$

Māori allegiance was not, however, as simple nor as whimsical as Clarke (junior) perceived. There were valid reasons, complex though they sometimes were, for who fought with who against whom - though the subprotector's tale is useful in highlighting the complexities of te ao Māori (the Māori world) in relation to kūpapa involvement in the New Zealand Wars. Lists of 'rebels', 'allies', and 'neutral' Māori - both official and unofficial - do not agree with one another. Iwi, hapū, and whānau were divided, and confused loyalties, self-interests, and trepidations influenced decisions. ${ }^{25}$ The Māori utilisation of European violence enhanced the mana of some Māori.

Furthermore, although at war, kūpapa expressed concern when it appeared their opponents were about to suffer heavy loss of life, and vice versa. ${ }^{26} \mathrm{Be}-$ ing of different hapū but of the same iwi, Heke and Wāka Nene were careful to ensure conflicts were fought with their overarching Ngāpuhi affiliation in

\footnotetext{
${ }^{24}$ Clarke (junior), Notes, pp.78-79

25 Maning, History of the War, pp.10-11; Belich, New Zealand Wars, pp.29-36; Belich, Making Peoples, pp.243-246; Wilson, From Hongi, pp.261-266; Burrows, 16 April 1845, Extracts, p.22

${ }^{26}$ Later kūpapa purposefully modified their bullets into blanks, which they fired at 'rebel' Māori when directed (and paid) by British military commanders; Maning, History of the War, pp.16-18; Wards, Shadow, p.284
} 
mind. ${ }^{27}$ As Clarke (junior) remembered, they 'came to an understanding as to the way in which the contest should be carried on'. 'The actual fighting was to be kept as much as possible on the ground between and about the opposing camps', the sub-protector wrote. 'Women, children, stragglers, and unarmed whites were not to be meddled with ... They were not to intercept each other's supplies, or to make raids on distant and defenceless villages, and they were to treat with humanity and kindness any of each others wounded who might fall into their hands'. After Heke was wounded, Wāka Nene and his toa reportedly knew his whereabouts, a few miles distant, 'and could have easily taken him if they had wanted to get him', but chose not to. After the war Wāka Nene successfully pleaded with Grey to secure clemency for Heke and Kawiti. On the other side, Heke reportedly had many chances to rupture kūpapa supply lines but refused to do so - even supplying enemy toa with fresh meat. The rangatira saw no glory in fighting half-starved and under-armed men whom with he had no personal resentment. '[I]f fight we must', he declared, 'let us fight like gentlemen' ${ }^{28}$

FitzRoy later recalled of Heke's actions that 'it became evident that the object was to bring about a collision with the government, which might have the effect of freeing that part of New Zealand from any British interference'. ${ }^{29}$ Upon hearing that the red-coated Pākehā soldiers were coming to the north following his multiple fellings of the flagstaff and the sacking of Kororāreka, however, Heke wrote to FitzRoy. The Ngāpuhi rangatira suggested to the kāwana: '[1]et your soldiers remain beyond the sea and at Auckland, do not send them here.' He reminded the governor that ' $[t]$ he pole that was cut down, belonged to me, I made it for the native Flag, and it was never paid

\footnotetext{
27 Marmon, Otago Witness, 1 April 1882, p.25; Buick, New Zealand's First War, p.143; Belich, New Zealand Wars, pp.34-36

${ }^{28}$ Clarke (junior), Notes, pp.75-76; New Zealander, 13 September 1845, p.2; Marmon, Otago Witness, 8 April 1882, p.25

29 FitzRoy, Remarks, p.37
} 
for by the Europeans. ${ }^{30}$ Heke had wanted to demonstrate to the Pākehā that they should refrain from interfering with rangatiratanga, but ultimately he sought the return of European trade to the Bay of Islands. Heke did not seek war with the British.

In early-September 1845 FitzRoy addressed a gathering of Ngāpuhi rangatira at Waimate - a hui Heke boycotted. The governor declared to those assembled: '[t]he conduct of Heke and his party, while at Kororarika, was so unbearable, that it obliged me to place soldiers there.' Of the flagstaff FitzRoy told the gathered Māori: 'in itself it is worth nothing, a mere stick; but as connected with the British Flag, [it is] of very great importance'. He further asserted that '[f]ormerly European nations attacked and conquered countries inhabited by uncivilized men, and to their everlasting disgrace, killed numbers of their men. But England acted differently.' ${ }^{31}$ Ngāpuhi likely recalled their knowledge of the colonisation of New South Wales and Van Diemen's Land when digesting the kāwana's assertion. Whereas Hongi Hika had united Ngāpuhi in the 1830s, Hōne Heke divided the iwi a decade later.

Tāmati Wāka Nene should not be viewed as wholly pro-Crown. As noted above, among his reasons for fighting a common enemy with the British were traditional inter-hapū motives, entirely separate from the Pākehā world. Moreover, although Wāka Nene had signed te Tiriti o Waitangi (as had Heke), and had encouraged others to do the same, when Native Secretary C.L. Nugent later attempted to investigate a number of internecine Māori killings in the Bay of Islands in 1847, Wāka Nene attempted to prevent the enforcement of British law. For the Ngāti Hao rangatira, British law did not suit these 1847 Māori conflicts, which concerned mākutu (sorcery) and

\footnotetext{
${ }^{30}$ Heke to FitzRoy, 19 July 1844, New Zealander, 19 November 1845, p.1; Rutherford, Heke's Rebellion, p.30

${ }^{31}$ New Zealander, 19 November 1845, p.1
} 
pūremu. Those Māori who signed te tiriti did not intend to sign their authority over to the Crown. As Ward suggests, in signing, Wāka Nene was not submitting to British law, rather he likely believed he was entering into an agreement with a powerful Pākehā rangatira to increase his own mana and aid his own aspirations. ${ }^{32}$

Upon being dismissed from his post as governor during a lull in the Northern War, FitzRoy wrote of the Treaty of Waitangi:

[s]ome persons still affect to deride it; some say it was a deception; and some would unhesitatingly set it aside; while others esteem it highly as a well considered and judicious work, of the utmost importance to both the coloured and the white man in New Zealand. That the natives did not view all its provisions in exactly the same light as our authorities is undoubted: but whatever minor objections maybe raised, the fact is now unquestionable that the loyalty, the fidelity, and co-operation of any natives in New Zealand has hitherto depended mainly on their reliance to the honor of Great Britain in adhering scrupulously to the treaty. ${ }^{33}$

Both Heke and Wāka Nene fought for the rangatiratanga promised to them in te Tiriti o Waitangi, which they had both signed almost five years previous. Both Heke and Wāke Nene also fought for the continuation of Pākehā trade in the north. They disagreed, however, on the best means to secure both rangatiratanga and Pākehā goods; thus they fought on opposing sides of the Northern War. ${ }^{34}$

${ }^{32}$ Ward, Show of Justice, p.81; Ward, 'Law and Law-enforcement', p.131

33 FitzRoy, Remarks, pp.9-10

34 Richard S. Hill, Introducing Policing to the Rangatiratanga Discourse: an Historical Overview of the Role of the Maori Police Personnel, Wellington:2003, p.2; Belich, New Zealand Wars, pp.34-36; Rogers, Te Wiremu, pp.166-167; cf. Head, pp.97-121 
FitzRoy's desperate pleas for assistance were further answered with the arrival, in Auckland on 22 April 1845, of 215 men of the 58th Regiment. These reinforcements, combined with regulars, volunteers, seamen, and marines, sailed north almost immediately under the command of Major Bridge. Upon their arrival in the Bay of Islands on 28 April 1845, FitzRoy declared martial law to be in effect in the north. Martial law was ended in the area by Governor Grey on 28 February 1846. ${ }^{35}$ In early-May 1845 it was reported in Sydney that another military detachment, led by Colonel Henry Despard, was soon to proceed to 'the sister colony'. Upon Despard's arrival in New Zealand, FitzRoy told the colonel, who took over the command of the British troops, that ' $[\mathrm{t}]$ he principal object of your expedition is the capture or destruction of the rebel chief Heki and his principal supporters.' 36

The colonial troops, reported by CMS missionary the Reverend Robert Burrows to have numbered ' 300 soldiers, about 100 marines and sailors, and 40 volunteers, besides Tamiti Waka and his men', marched inland from Kerikeri. ${ }^{37}$ Before the arrival of the colonial forces in the north, however, Wāka Nene and his toa had been harassing Heke and his men as they attempted to construct a new pā at Puketutu in anticipation of the appearance of the British. ${ }^{38}$ Kūpapa rangatira further assisted the British forces by aiding in the planning of attacks and by writing to the British updating them on the movements and progress of Heke and Kawiti. ${ }^{39}$

\footnotetext{
35 Nelson Examiner and New Zealand Chronicle, 21 February 1846, p.203; New Zealander, 19 November 1845, p.1; Clarke to McLean, 21 May 1845, MS-Papers-0032-0215, Object\#1027314, ATL; Bridge, journal, 28 April 1845, MS-0257, ATL; Belich, New Zealand Wars, p.41

${ }^{36}$ Australian, 6 May 1845, p.3; FitzRoy to Despard, 6 June 1845, NZSCSG, 10 February 1847, pp.34

37 Burrows, 7 May 1845, Extracts, p.25; Despard to FitzRoy, 2 July 1845, New Zealander, 19 November 1845, p.1

${ }^{38}$ Burrows, 1-30 April 1845, Extracts, pp.18-24; New Zealander, 19 November 1845, p.1; Belich, New Zealand Wars, pp.41-42

39 see for example: Bridge, journal, 1, 15 \& 18 May and 13 June 1845, MS-0257, ATL; Buick, New Zealand's First War, p.129
} 
Prior to what has been described as 'the most important engagement of the war', the battle of Ohaeawai, Heke was again 'much harassed' by Wāka Nene's toa. ${ }^{40}$ As FitzRoy informed Bridge upon his arrival in the colony: 'Tamati Waka Nene had been fighting Heki and had beaten him into a corner where he said he would hold him till the Governor sent the troops round to take him prisoner' ${ }^{41}$ The kūpapa tauā, numbering two- or three-hundred warriors, had taken the empty Te Ahuahu pā and violently opposed Heke when he tried to retake it with some four- or five-hundred men on 12 June 1845. During the affray Heke was 'severely wounded in the thigh', from which a musket ball was later removed. Moreover, an important new ally who had recently joined Heke, Te Kahakaha, was killed, as were 'some other considerable chiefs'. It was also reported that 'some few lives were lost on Nene's side'. As Clarke informed Sub-Protector McLean, 'Heke had been again defeated by Walker [Wāka] and himself badly wounded ... I hope to learn that an end is put to this sad desolating war' ${ }^{42}$

On the afternoon of 1 July 1845, Colonel Despard's troops attacked Heke's pā at Ohaeawai. The attack was, in Despard's own words, 'without success'. '[W]e were', he reported, 'repulsed with heavy loss'. 'The story of that assault', Lindsay Buick concluded, 'made in the bright sunlight of a July day, is one of the most unhappy in the history of the British arms.'43 'One third of the men actually engaged fell in the attack' on Ohaeawai, Despard reported, 'and during the eight days that we have been engaged carrying on operations against this place, one fourth of the whole strength of British soldiery

40 Belich, New Zealand Wars, p.45; NZSCSG, 30 August 1845, p.3

41 Bridge, journal, 22 April 1845, MS-0257, ATL

42 New Zealander, 21 June 1845, p.2; Clarke to McLean, 27 June 1845, MS-Papers-0032-0215, Object\#1018453, ATL; Bridge, journal, 13 June 1845, MS-0257, ATL; Belich, New Zealand Wars, pp.45-47; Wards, Shadow, p.151; FitzRoy, Remarks, pp.49-50; Buick, New Zealand's First War, pp.136-145

43 Buick, New Zealand's First War, p.170 
under my command, (originally not exceeding 490), have been either killed or wounded. ${ }^{44}$

Despite Despard's correspondence, FitzRoy publicly declared a British victory at Ohaeawai - but the Pākehā public were unconvinced. ${ }^{45}$ Following the defeat, a writer for the New Zealand Spectator and Cook's Strait Guardian lamented '[t]he destruction of Kororarika, and a warfare in which already the British forces have been twice (and if the rumour now current be should unfortunately prove true, thrice) defeated; a protracted warfare, in which already many valuable lives have been sacrificed, and of which under Captain FitzRoy no one can predict the result'. 'How much more of disaster and disgrace, or misery and ruin', the author asked, 'is this unfortunate colony destined to suffer from Capt. FitzRoy, before his successor arrives!'46 The answer was multifarious, for although FitzRoy was replaced as governor, war continued under his successor.

For five months after Ohaeawai there was no fighting as FitzRoy attempted to secure peace following the resounding British defeat. The governor knew, from September, that he was to be replaced, and did not wish to begin fresh conflict which he would have to relinquish to his replacement. ${ }^{47}$ From a Māori perspective this break in the war was at least in part occasioned by it being the season for cultivation, when toa returned to their kāinga to tend

\footnotetext{
44 Despard to FitzRoy, 2 July 1845, Wellington Independent, 9 August 1845, p.3; Clarke to McLean, 19 June 1845, MS-Papers-0032-0215, Object\#1015211, ATL; NZSCSG, 9 August 1845, p.2; New Zealander, 19 November 1845, p.1; FitzRoy, Remarks, p.50n; Rutherford, Heke's Rebellion, pp.24-25 \& 38-40; Buick, New Zealand's First War, pp.145-189

45 New Zealander, 13 September 1845, p.2; Nelson Examiner and New Zealand Chronicle, 29 November 1845, p.154 \& 30 August 1845, p.103; Clarke to McLean, 13 September 1845, MS-Papers0032-0215, Object\#1004731, ATL

${ }^{46}$ NZSCSG, 9 August 1845, p.2, emphasis in original; Wellington Independent, 9 August 1845, p.2

47 New Zealander, 19 November 1845, p.1; Belich, New Zealand Wars, pp.54-57; Wards, Shadow, p.179
} 
their crops. ${ }^{48}$ 'Can shadows carry muskets?', Heke's tauā cried. ${ }^{49}$ This economic need had also earlier retarded Kawiti's efforts to defend Ohaeawai..$^{50}$ The dilemma of part-time warriors fighting full-time soldiers was a handicap which was to plague Māori throughout the New Zealand Wars.

FitzRoy has been eulogised, somewhat unfairly, as 'perhaps New Zealand's best-intentioned governor, and certainly one of its most incompetent' ${ }^{51}$ Following his failure to secure a decisive victory at Ohaeawai, FitzRoy was dismissed..$^{52}$ He had arrived in the colony in December 1843, and was replaced by George Grey in mid-November 1845. The Northern War was not yet over.

Governor Grey continued to utilise kūpapa in the Northern War. The incumbent governor quickly realised that the British war effort relied heavily on the support of Wāka Nene and his people. Upon his arrival in the colony he met with various kūpapa rangatira. ${ }^{53}$ The following month he wrote to Lord Stanley, informing the secretary of state for colonies that kūpapa 'afford the most essential assistance to Her Majesty's forces; indeed I do not think that our operations would be successfully conducted without their cooperation' ${ }^{54}$

\footnotetext{
48 New Zealander, 13 September 1845, p.2

49 Maning, History of the War, p.48; Best, 'Maori Agriculture', passim, esp. p.364

50 Belich, Making Peoples, p.208

51 lan Wards disagreed, suggesting instead that FitzRoy was the victim of a lack of sufficient power to implement the means necessary for effective government; Sinclair, Origins, p.34; Wards, Shadow, pp.70-94, esp. p.72

52 In addition to his military failures, FitzRoy was relieved of his governorship owing to the New Zealand Company, upset by many of his policies and actions, having 'pulled political strings in England'; Rogers, Te Wiremu, pp.214-215; FitzRoy, Remarks, pp.50 \& 55-64; J. Adams, 'Governor FitzRoy's Debentures', pp.44-63

53 Bridge, journal, 28 November 1845, MS-0257, ATL

54 Grey to Stanley, 11 November 1845, cited in Wards, Shadow, p.197; Ward, Show of Justice, p.72
} 
In late-December 1845 and early-January 1846 the British attacked Ruapekapeka pā with some 1300 European men, aided by an unknown number of kūpapa toa (though likely significantly less than the oft-cited figure of 850). ${ }^{55}$ Küpapa involvement in the attack was significant. Despard informed Grey that during the fighting at Ruapekapeka on 2 January 'the European troops acted only as a reserve, at the particular desire of the Native chiefs, who were fearful that their own people might be mistaken for the enemy and fired upon'.56 On 11 January Despard reported to the governor that Ruapekapeka had been taken by the British. 'The capture of a fortress, of such extraordinary strength, by assault, and nobly defended by a brave and determined enemy, is of itself sufficient to prove the intrepidity and gallantry displayed by all concerned', he declared. ${ }^{57}$ This victory was in reality, however, not as reported by the colonel.

Ruapekapeka pā was well designed to withstand the British attack. ${ }^{58}$ After days of enduring assault by the might of the British Empire, however, the pā was found practically empty on 11 January. The reasons for Heke's abandonment of Ruapekapeka have been much argued over, but it was probably due to a combination of: the occupants' irritation at the incessant thunderous noise and consequent lack of sleep owing to mortars (which did little physical damage, but much mental harm); the slow disintegration of the pā under the British assault; and Heke's desire to draw the Pākehā soldiers into com-

\footnotetext{
55 Belich, New Zealand Wars, pp.58-59; Belich, Making Peoples, pp.207-208; Wilson, From Hongi, pp. 270-271

56 FitzRoy had earlier foreseen the difficulty in 'distinguishing friend from foe', and had suggested kūpapa wear a 'band round the head, or body, or neck' to distinguish them from 'rebel' Māori; Despard to Grey, 5 January 1846, New Zealander, 24 January 1846, p.4; FitzRoy to Despard, 6 June 1845, NZSCSG, 10 February 1847, pp.3-4

57 Despard to Grey, 11 January 1846, New Zealander, 24 January 1846, p.4

58 Bridge, journal, 11 January 1846, MS-0258, ATL; Maning, History of the War, pp.45-46; FitzRoy, Remarks, p.54
} 
bat in the surrounding bush, an advantageous theatre for Māori. A less likely explanation is that the pā was found empty on the Sabbath, while most toa were outside conducting prayers, and Kawiti, not expecting to be assaulted on Rātapu (Sunday), ${ }^{59}$ was asleep with only eleven other men inside the pā. ${ }^{60}$ Regardless of the much-debated reasons, the fact remains the pā was near-unoccupied when the British stormed it. ${ }^{61}$ On that Sunday, a number of kūpapa toa led by Wāka Nene's brother, William Wāka, crept up to the pā and established that it was practically empty. They relayed this information to the British, who then took the pā virtually unopposed. Heke and Kawiti's forces then attacked the British, with both sides suffering significant losses.

Colonial officials, led by Grey and Despard, exaggerated the Crown's occupation of an empty pā into a victorious assault on, and successful capture of, a well-defended and near-impregnable bastion. At the close of the Northern War the Nelson Examiner led with the headline: 'Important News: Total Defeat of the Rebels. Surrender of Heki and Kawiti.' ${ }^{62}$ Ten weeks following this victorious headline however, the New Zealander proclaimed: 'Defeat in New Zealand.' 'The savage', the writer went on to declare, 'had repulsed his civilized enemy.' ${ }^{63}$

59 The Rātapu explanation, if accorded any weight, is complicated by FitzRoy's demand of Despard, at the war's outbreak, that 'the religious feelings of those who have profited by the zealous efforts of the missionaries, will be fully respected'; FitzRoy to Despard, 6 June 1845, NZSCSG, 10 February 1847, p.3

${ }^{60}$ Bridge, journal, 11 January 1846, MS-0258, ATL; Maning, History of the War, pp.45-48; James Cowan, The New Zealand Wars: a History of the Maori Campaigns and the Pioneering Period, 2 vols., Wellington:1922-1923, i:pp.73-87; Buick, New Zealand's First War, pp.253-258; McDonnell, p.507; Burrows, 4 January 1846, Extracts, pp.54-55; Rutherford, Heke's Rebellion, p.41

${ }^{61}$ Both Belich and Wards dispute the Rātapu explanation. They suggest that Māori well-knew the British would fight on Sundays as they had done so previously, and instead propose that a strategic abandonment of Ruapekapeka had been planned and successfully executed; Belich, New Zealand Wars, pp.58-64; Wards, Shadow, pp.201-202

62 Nelson Examiner and New Zealand Chronicle, 14 February 1846, p.199

63 New Zealander, 2 May 1846, p.4 
A writer for the New Zealander contemporaneously asserted that Grey's official despatches were 'Truth in masquerade with a witness'. Expressing concern for 'the future historian of New Zealand, who may be rather apt to mislead his readers if he follows the text of these official documents too closely', the writer further announced that Grey's despatches 'certainly contain the truth, but ... what with the embellishments and the omissions, the truth is very much shorn of its lustre'. ${ }^{64}$ Another contemporary accused Grey of 'pure invention', and asserted 'he has been over-lavish of untruth' during his governorship. ${ }^{65}$ Like the governor's assertions, John Williams' 1846 painting Storming of the Pa at Ruapekapeka, 11th January 1846 depicts British soldiers clambering into a seemingly well-defended pā. As Carleton dryly observed however, ' $[t]$ here is some difference between taking pa by assault, and getting into an empty one.' 66 These contemporary warnings were quickly forgotten, however, and remained so until Belich disabused the long-standing historiographical claims of wholesale British victory in the Northern War, and the remainder of the New Zealand Wars, in the mid-1980s. ${ }^{67}$ The stalemate at Ruapekapeka ended the Northern War. ${ }^{68}$

Kūpapa certainly did not unquestioningly follow British instructions. Kūpapa toa listened to their rangatira, and kūpapa rangatira sometimes con-

\footnotetext{
64 ibid., 19 December 1846, p.2; see also: 24 January 1846, p.2; Daily Southern Cross, 13 November 1847, p. 2

65 Metoikos to the editor, Daily Southern Cross, 17 December 1852, pp.2-3; see also: Bryan Gilling, 'Grey, Sir George Edward', in Ian McGibbon (ed.), The Oxford Companion to New Zealand Military History, Auckland:2000, p.209; 'Metoikos' was possibly Hugh Carleton, who is known to have used this pseudonym; McLintock, p.3n

${ }^{66}$ Carleton, ii:p.125

67 Belich, New Zealand Wars, passim

${ }^{68}$ Maning, History of the War, p.48; Belich, New Zealand Wars, pp.64-70; Wilson, From Hongi, pp.274-279; Walker, pp.103-105; Wards, Shadow, pp.203-205
} 
sulted the British, but ultimately acted as they wished. ${ }^{69}$ Struggling with his Pākehā allies' ways, Wāka Nene was apparently so incensed at the needless waste of so many lives during the war that he 'tore from a Maori whare a long stick, and hit the commander of the Queen's forces a blow on the head with it' ${ }^{70}$

As Belich argues, for kūpapa involved in the New Zealand Wars, the British were fighting for them, they were not fighting for the Queen. Wāka Nene would have fought Heke with or without British support or approval. Heke specifically informed FitzRoy that Wāka Nene had only allied with the British for personal gain. ${ }^{71}$ He blamed kūpapa for the continued hostilities when he himself sought peace. ${ }^{72}$ Wāka Nene on the other hand, let the governor know that he did not intend to fight a decisive battle with the loss of many lives against his fellow Ngāpuhi. Heke must, he proclaimed, be defeated by Pākehā. Wāka Nene intended instead to harass Heke until the British could organise their troops, then aid them in a limited manner.

What Wāka Nene sought from FitzRoy was ammunition to secure utu for past slights against his hapū and whakapapa, and British assistance to secure said reciprocity. In May 1845 FitzRoy sent Wāka Nene a letter commending his support of the British in the war, and telling him 'he would mention his brave conduct to the Queen of England, and that his name would be great in times to come'. Accompanying this letter was tobacco, blankets, sugar, rice, half a ton of gunpowder, and half a ton of shot. ${ }^{73}$ That same month kūpapa rangatira Wi Repa was given a musket, a sword, ammunition, and clothing

\footnotetext{
69 see for example: James Merrett, 'Narrative of the Heki Campaign', Wellington Independent, 21 June 1845, pp.1-3

70 McDonnell, p.506; see also: Burrows, 1 July 1845, Extracts, pp.39-40

71 Belich, New Zealand Wars, pp.34-36; Belich, Making Peoples, p.246; Wards, Shadow, p.145

72 Wards, Shadow, p.180

73 Marmon, Otago Witness, 1 April 1882, p.25
} 
for his assistance in opposing Heke, 'which delighted him'. When kūpapa toa were later asked 'to carry down the remainder of our wounded', Bridge found 'they would not do it without being provided with 4 blankets each' ${ }^{74}$

Although kūpapa fought at their own direction, for their own reasons, their conflict with Heke and Kawiti certainly aided the British cause. While Heke's toa 'vaunted of their warlike deeds, and of having killed and wounded a much greater number of soldiers that they had lost', they added that it was Wāka Nene's kūpapa forces 'who had frustrated them'. '[H]ad [kūpapa] not taken arms', Heke's toa declared, 'the soldiers might have come to the Waimate, but they should never have returned'. '[H]ad not the troops Waka to protect them', 'rebel' Māori boasted, 'they would instantly attack them at the Waimate'.$^{75}$ When he first learnt of Wāka Nene's intent to oppose him, Heke had said: '[1]et Waka keep to his own side of the Island, Hokianga, and not interfere with $\mathrm{me}^{\prime} .{ }^{76}$

Heke was reluctant to fight Wāka Nene's kūpapa toa. Just over a week after the sacking of Kororāreka, Wāka Nene arrived in the Waimate district with some 300 warriors, and reported that another 1000 were on their way to join him. Trying to draw Heke into a fight, Wāka Nene openly insulted him. Heke, however, sought peace; his grievance was with the Crown. Heke's concern was rejected by Wāka Nene, who wished to engage Heke until the arrival of British reinforcements. The Ngāti Hao tauā continued to harass Ngāti Rahiri, fighting a number of skirmishes while the latter hapū attempted to prepare for the British attack. ${ }^{77}$

\footnotetext{
74 Bridge, journal, 25 May \& 5 July 1845, MS-0257, ATL

75 New Zealander, 13 September 1845, p.2

76 Burrows, Extracts, p.8

77 Wilson, From Hongi, pp.271-275; Buick, New Zealand's First War, pp.100-102
} 
Küpapa assistance was vital to the British war effort in the Northern War and the British recognised their dependency on Māori violence. Following the fighting at Ruapekapeka, Despard wrote to Grey expressing his 'admiration at the brave and intrepid conduct displayed by our native allies on every occasion since these operations commenced, and more particularly during the assault of the pah, on which occasion their bravery was fully equal to what might be expected from the bravest of Her Majesty's troops' ${ }^{78}$ FitzRoy later wrote that he had at first declined to sanction Wāka Nene's war with Heke, 'believing that such a war, without the control of government, would degenerate into interminable hostilities between various tribes, and speedily ruin what the missionaries had effected during a long course of years'. 'It was, however, soon afterwards discovered', the former-governor concluded, 'that to the assistance of the loyal natives we owed so much that our troops could not act without their constant presence; and that, as the less of two evils, they must be engaged'.$^{79}$

A writer for the New Zealander declared that 'the real hero of the campaigns' was Wāka Nene, who 'did nearly all the work, who for a time supported only by his own adherents sustained the burden of the conflict, and saved the capital from destruction' ${ }^{80}$ Chief Protector Clarke concluded of FitzRoy's utilisation of kūpapa: 'he secured not only the allegiance, but the assistance of those, who if they had taken part with the malcontents, would have rendered the insurrection still more formidable, but whose aid saved the colony $^{\prime} \cdot{ }^{81}$

\footnotetext{
78 Despard to Grey, 11 January 1846, New Zealander, 24 January 1846, p.4

79 FitzRoy, Remarks, p.47

80 New Zealander, 19 December 1846, p.2

${ }^{81}$ Clarke, Final Report, pp.6-7
} 
Following Ruapekapeka the Crown sought peace. In keeping with his assertion that the war had ended in victory for the British, Grey made a series of demands on which peace was conditional. Heke openly disobeyed these, but his defiance was ignored by Grey. A correspondent for the New Zealander reported in April 1846 that, although Grey had specifically proclaimed that horses stolen from Kororāreka during the attack on the township 'must forthwith be restored to their proper owners', Heke defiantly kept a number of stolen mounts at Whangārei, 'which he declares he will not give up'. 'So much for the "brilliant successes" at Rua-peka-peka', the author sardonically concluded. ${ }^{82}$ Separate from Crown intent or direction, Wāka Nene met Heke and Kawiti at a neutral pā a week after the battle at Ruapekapeka and agreed to peace..$^{83}$

For his support in the Northern War the Crown built for Wāka Nene a fourroom house at Kororāreka; paid him a $£ 100$ annual pension, with another $£ 100$ to distribute among other 'loyal' rangatira; and gave him occasional further gifts of blankets, flour, sugar, tobacco, and pipes. ${ }^{84} \mathrm{Ku}$ papa had initially been promised by FitzRoy that all 'rebel' Māori land would be confiscated and redistributed among 'loyal' Māori, and that no land would be taken by the Crown. At the war's conclusion, however, Wāka Nene implored Grey not to confiscate land from Heke and Kawiti - yet another thread in the complicated tangle of iwi and hapū ties and the related limited kūpapa allegiance to the Crown. Grey heeded this shrewd advice. ${ }^{85}$

\footnotetext{
${ }^{82}$ New Zealander, 4 April 1846, p.2; FitzRoy, Remarks, pp.37-39

83 Belich, New Zealand Wars, p.60

84 Nelson Examiner and New Zealand Chronicle, 18 December 1847, p.165; Wards, Shadow, pp.205-206

85 FitzRoy to Despard, 6 June 1845; Grey to Stanley, 26 June 1846 - NZSCSG, 10 February 1847, pp.3-4
} 
During the Northern War, one section of Ngāpuhi, led by Heke and Kawiti, fought against the British, who were aided by other Ngāpuhi - kūpapa - led principally by Wāka Nene, who was supported by Hōne Mohi Tāwhai, Eruera Maihi Patuone, and Makoare Te Taonui. Wāka Nene won this 'war within a war' he fought against Heke, though this kūpapa victory did not secure British success. The Northern War was a stalemate; FitzRoy's declared intention to capture or kill Heke remained unfulfilled, while Heke's attempt to dispel British sovereignty was also unsuccessful. ${ }^{86}$

It was the counsel of kūpapa leader Hōne Mohi Tāwhai which had, at Ruapekapeka, 'saved, in all human probability, the like fatal results which occurred to our forces at the disastrous storming of Ohiawai' ${ }^{87}$ In Sydney it was reported that said 'disastrous' attack on Ohaeawai should never have been made, as Wāka Nene had informed the British of the senselessness of doing so. ${ }^{88}$ Upon the conclusion of the Northern War, Burrows observed: '[i]t is not easy even to guess to what dimensions Heke's rebellion would have spread, had not Waka taken up arms in defence of law and order, as a loyal subject of the Queen. ${ }^{\prime 9}$ While Wāka Nene's reasons for opposing Heke certainly differed from Burrows' claimed loyalty to Victoria, his role in both preventing the spread of the Northern War and in bringing the conflict to an end were paramount. The European utilisation of Māori violence was vital to the colonisation of New Zealand. Europeans well-understood this dependency, even if military commanders and colonial officials were reluctant to admit depending on Māori.

\footnotetext{
86 Belich, New Zealand Wars, pp.29 \& 64-70; Belich, Making Peoples, p.208; Wards, Shadow, pp.143-144 \& 197

87 Metoikos to the editor, Daily Southern Cross, 17 December 1852, p.2

88 Sydney Morning Herald, 13 June 1845, p.2

${ }^{89}$ Burrows, Extracts, p.58
} 
Hōne Wiremu Heke Pōkai died in 1850 - rumoured to have been killed by his wife. Te Ruki Kawiti died in 1854, having accepted Christianity following the conclusion of the Northern War. '[P]erhaps', one sceptical historian speculated, 'the moral of sleeping-in on Sunday mornings had not been lost on him'. After the war, Tāmiti Wāka Nene continued to assist the Crown in its dealings with Māori until his death in $1871 .^{90}$

Upon the conclusion of the Northern War Grey informed Lord Stanley that he sought 'to show the native population generally throughout the islands, that in the event of their engaging in active rebellion, they would forfeit their properties, and that I would certainly for the future severely punish those who were guilty of this crime' ${ }^{91}$ Grey left New Zealand in 1853, bound for the governorship of the Cape Colony. His portentous declaration would come to pass on his return for his second term as governor. Grey returned to New Zealand in 1861, bringing with him wallabies (which flourished), zebra (which did not), monkeys (which he shot upon tiring of), and more warfare. ${ }^{92}$

Between 1860 and 1872 the British engaged in various conflicts against various groups of Māori. These engagements, often including the Northern and Southern Wars, are collectively known as the New Zealand Wars. ${ }^{93}$ Prior to the 1970s it was generally accepted that land-hunger was the Europeans' primary, even sole, motivation for their aggression; a focus which culmi-

\footnotetext{
90 New Zealander, 8 August 1846, p.2; FitzRoy, Remarks, p.56n; Burrows, Extracts, pp.55-57; Wards, Shadow, p.206; cf. Rutherford, Heke's Rebellion, p.31n

91 Grey to Stanley, 26 January 1846, NZSCSG, 10 February 1847, p.3

92 Belich, Making Peoples, pp.190-191; James Gump, 'The Imperialism of Cultural Assimilation: Sir George Grey's Encounter with the Maori and the Xhosa, 1845-1868', Journal of World History, 9:1, 1998, pp.91 \& 101

93 The suppression of Rua Kēnana's movement in 1916 has been identified as 'in effect the last shooting' of the New Zealand Wars. Belich further suggests the 1843 Wairau affray could be seen as the opening of the wars; Alan Ward, 'The Origins of the Anglo-Maori Wars: a Reconsideration', NZJH, 1:2, 1967, pp.166-167; James Belich, 'New Zealand Wars', in McGibbon (ed.), pp.370-374; Hill, 'Maori Police Personnel', p.176; Hill, Introducing Policing, pp.2-3
} 
nated in J. Henderson's contemporaneously widely-applauded suggestion that the term 'Land Wars' was more appropriate than the then accepted term 'Maori Wars'. Pākehā hunger for land was an important cause of the wars, but its importance has been overstated to the detriment of other important factors. In addition to land-hunger, contributing factors to the war included: Grey's personality, policies, and the complex relationships with Māori rangatira he formed in his first term as governor; the glories, promotions, and plunders offered by war; a desire to enforce sovereignty, or the opportunity to violently 'civilise' the 'lawless' and 'savage' Māori - British subjects since 1840; the perceived need to stamp the authority of a 'superior' race; a philanthropic desire for amalgamation in the wake of the Australian colonial experience; and, of course, Māori resistance to these Pākehā desires. ${ }^{94}$

Küpapa assistance remained extremely important to the British war effort throughout the New Zealand Wars. ${ }^{95}$ Belich notes that without kūpapa the wars against Tìtokowaru and Te Kooti may well have been lost. Although acknowledging '[m]ight-have-been history is a dangerous game', he adds that it is hard to see how the British could have won the New Zealand Wars without kūpapa aid. ${ }^{96}$

Grey was appointed governor of the colony of New Zealand in late-1845 partly because he was seen as a viable means of quashing the rebellion in the north, but also because he had voiced to colonial officials ideas concerning

\footnotetext{
94 Some wits unknown ably highlighted the evolving debate over the appropriate label for the conflicts on the title page of a copy of Gibson's Maori Wars held in the Victoria University of Wellington library, upon which someone has crossed out 'Maori' and replace it with 'Pakeha', which has later been usurped by 'NZ'. Ward had earlier offered the term 'Anglo-Maori Wars'. The historiography has since come full-circle, from Cowan's New Zealand Wars (1922) to Belich's New Zealand Wars (1986).

95 Belich, New Zealand Wars, passim; Belich, Making Peoples, pp.229-272; James Belich, 'I Shall Not Die': Titokowaru's War, New Zealand, 1868-9, Wellington:1989, passim; Burnett, pp.227-230; Green, 'Kupapa', in McGibbon (ed.), pp.271-272

96 Belich, New Zealand Wars, pp.211-213; Belich, Making Peoples, p.246
} 
the rapid assimilation of indigenous peoples into 'civilised' European ways. Grey continued FitzRoy's utilisation of Māori violence in the Northern War upon his arrival in the colony, as he did in the later New Zealand Wars he presided over. Following the conclusion of the war in the north, Grey continued to utilise Māori violence in the pursuit of his dual goals of enforced British law and coerced 'civilisation', this time in the form of militarised policing.

In another manifestation of the colonial utilisation of indigenous violence, many Māori were employed as police on the New Zealand frontier. As with the other side of the Tasman world, where Aboriginal police were recruited owing to their tracking and bush skills, Māori police were recruited to police other Māori because of their knowledge of the New Zealand environment. They were also utilised as police owing to their knowledge of te ao Māori. ${ }^{97}$ '[T]he Government were not brave enough, nor had not confidence in themselves to carry out the laws that they made', rangatira Kowhia Kaka later informed Lieutenant-Colonel Thomas McDonnell of policing Māori in the 1840s. 'The cry was, "We are afraid to send [Pākehā] policemen here, lest," as they urged, "they be cooked and eaten."'98 The employment of Māori police was an attempt to circumnavigate this fear and enforce British law and 'civilisation' upon Māori.

As with the Port Phillip Native Police, discussed in the previous chapter, enquiring why Māori willingly policed 'fellow Māori' can be misguided, and paints an invented portrait of a homogenous nineteenth-century Māori.

97 Hill, Introducing Policing, p.4; Richard Hill, 'Maori Policing in Nineteenth Century New Zealand', Archifacts, 2, 1985, pp.54-55; Terry, pp.269-270

98 McDonnell, p.512 
Māori constables often policed members of other iwi, other hapū, or other whānau to share as agents in colonial power and to gain advantage over traditional rivals. When Māori policemen struggled to balance their dual roles - both being Māori and being Crown policemen - and the various expectations which came with these, it sometimes killed them. ${ }^{99}$ Paramount to both personal problems and benefits, however, some rangatira believed that if they assisted the Crown, the Crown would not usurp their power; though this often proved a false hope. ${ }^{100}$

Richard Hill identifies the CMS missionaries and their Māori adherents as the first police in New Zealand - they policed both Māori and visiting Pākehā behaviour from 1814. In a direct colonial utilisation of Māori violence, in 1815 New South Wales Governor Macquarie appointed Ngāpuhi rangatira Hongi Hika, Ruatara, and Korokoro police constables, whose job it was to regulate Māori-Pākehā contact. These men were paid a military uniform and one cow each for their services. ${ }^{101}$

As examined in chapter four, when James Busby arrived in the Bay of Islands as British Resident in 1833 he had trouble establishing his authority. He requested from New South Wales Governor Bourke funds to employ a Māori police force to overcome this difficulty. Bourke, however, refused. ${ }^{102}$ It was following the signing of te Tiriti o Waitangi that colonial efforts to suppress Māori violence grew to include the utilisation of Māori violence. As is also explored in chapter four, Māori noted that they had been promised

\footnotetext{
99 Sergeant Karira of the Taranaki police died in 1867, owing, he believed, to a ngārara (reptile) having hold of his throat - a traditional punishment for violating tapu; Richard S. Hill, 'Karira', DNZB; Hill, 'Maori Police Personnel', pp.185-186; Hill, Introducing Policing, p.14; Yate, Account, pp.141-142

100 Hill, 'Maori Police Personnel', pp.177-178 \& 186; Hill, Introducing Policing, pp.4-5; Hill, 'Maori Policing', p.56

101 Hill, Policing the Colonial Frontier, i:pp.35-47; Hill, 'Maori Policing', p.55; Belich, Making Peoples, p.157

102 Hill, Policing the Colonial Frontier, i:pp.60-61; Newman, p.81; Adams, Fatal Necessity, p.71
} 
rangatiratanga in article two of te tiriti, while the Crown stressed that article one of the treaty had transferred Māori sovereignty to Britain. Technically, both were right. 'As a result' of this disagreement, Hill notes, 'tension has been endemic, and where there is tension there is policing' ${ }^{103}$

In response to increasing Māori-Pākehā tension in northern New Zealand in mid-1840, the idea that Māori might be employed in a similar role to sepoys was proposed by the Colonial Office, but nothing came of it. ${ }^{104}$ It was Grey who was the first to utilise Māori for internecine policing purposes on a large scale, which he did from 1846 as he sought 'the control of both races'. ${ }^{105}$

Upon his arrival in New Zealand as governor, Grey immediately founded an armed police force. In October 1846 a Constabulary Ordinance was enacted by the Legislative Council, officially authorising the recruitment of armed police in New Zealand - thus legalising something Grey was already doing. Both prior to and following the enactment of the Constabulary Ordinance, Māori were enrolled alongside Pākehā in Grey's armed police, which was headed by British officers.

Upon introducing the Constabulary Ordinance to the Legislative Council in October 1846, Grey addressed the council on the recruitment of Māori police in the colony. On the intention that employing Māori policemen would promote 'civilisation' among Māori, the governor informed the council:

[a]lready some progress has been recently made in the attainment of this objective, as the Natives when employed in the Police Force, and paid, fed, and clothed in all respects in the same manner as Europeans,

\footnotetext{
103 Hill, 'Maori Police Personnel', p.175; Hill, Introducing Policing, p.1

104 Wards, Shadow, pp.52-53

105 Hill, Policing the Colonial Frontier, i:pp.235-335; Richard Hill, “"The control of both races”: the Policing of the Wellington Settlement, 1840-1853', New Zealand Studies, 7:1, 1997, pp.3-13
} 
have not only proved active and valuable constables, but have so completely emancipated themselves from their former prejudices as not to hesitate to assist in the apprehension of offenders of their own race, whatever might be their rank or influence.

Two days later, at the second reading of the ordinance, the colonial secretary announced that the intention of the governor 'was to organize a force similar to that which had been established in other British Colonies'.

'When depredations were committed by the aborigines, and it became necessary to apprehend the offenders, the Native Police would be found most useful instruments in the hands of the Government for this purpose', Grey's colonial secretary declared on the governor's behalf.

The Native Chiefs for the most part are jealous of men of other nations exercising authority over them, and might be expected to show great obstinacy in giving up an offender to a European constable; but when the duty was performed by a Native police-man, that jealousy would be in a great measure removed, and the ends of justice more speedily and safely brought about.

In addition to promoting 'civilisation' among Māori and increasing the speed and safety of the implementation of British law, the governor believed that, in the wake of the Northern War, that 'in the event of another native insurrection breaking out, the friendly natives would have the advantage of being properly drilled and disciplined, and thus be enabled to act more powerfully in quelling any hostile movement'. ${ }^{106}$

The colonial secretary's assertion that Māori would not object to being policed by Māori proved incorrect in practice. In November 1848 a Hokianga correspondent for the Daily Southern Cross reported that upon witnessing the

\footnotetext{
106 New Zealander, 10 October 1846, pp.2-3; NZSCSG, 11 November 1846, p.3; Wellington Independent, 21 November 1846, p.4; Nelson Examiner and New Zealand Chronicle, 12 December 1846, p.162; Sydney Morning Herald, 10 November 1846, p.3
} 
Māori police 'going through their exercises', a Bay of Islands rangatira spoke to the Māori policemen. 'You Waikato men who come here with your "whicks penete" (fix bayonets) get home again; get home again; or some day you are sure to find yourselves whicks penete in a Maori oven.'107 Inter-iwi and inter-hapū rivalries affected colonial attempts to utilise Māori violence through policing, just as they had during wartime.

Similarly, iwi and hapū ties impeded the effectiveness of Grey's Māori police. While on the one hand Captain Charles Brown found the Native Police more obedient under discipline than would be readily imagined, considering the proximity of their native friends and relations', generally Māori were reluctant to police their relatives and traditional allies. ${ }^{108}$ In inquiring into the provisions of the Native Offenders Bill in July 1856, a select committee asked Thomas Beckham, resident magistrate of Auckland, '[w]hen warrants are out against Native Offenders, do Natives generally assist in their apprehension?' Beckham replied: 'I don't think Native Police are at all instrumental in getting information against Offenders' ${ }^{109}$ Grey further found that some Māori faced violent punishment among their hapū for having joined his police force. ${ }^{110}$ Some Māori were killed for being Crown policemen. ${ }^{111}$

Grey's intentions for the colonial utilisation of Māori police are well summed up by the reminiscences of a Legislative Council member, who recalled why he had supported the governor's Constabulary Ordinance. He had

advocated in the council, the propriety of establishing a Police Force, partly composed of Natives, and partly of Europeans, as a measure in-

\footnotetext{
107 Daily Southern Cross, 11 November 1848, pp.2-3, italics in original

108 Charles Brown to secretary of state, 8 February 1858, Appendices to the Journals of the House of Representatives (AJHR), 1863, Session I, E-18, p.4

109 AJHR, 1860, Session I, E-05a, p.11

110 Grey to Cardwell, 4 April 1865, AJHR, 1865, Session I, A-05, p.16

111 see for example: 'Papers Relative to the Murder of Kereti', AJHR, 1865, Session I, E-06
} 
timately connected with the accomplishment of two objects, which always seemed to him to be essential to the progress, if not to the existence of the colony, namely, the amalgamation of the races, and the security of life and property in the rural districts.

'Such a force', he noted, 'might be called a colonising regiment, as at once inducing, promoting and protecting colonization'. His opinions, he added, had been shaped by those of Grey. ${ }^{112}$

As was the goal of the Port Phillip Native Police Corps, Grey hoped his police force would 'civilise' its Māori members, who would then permeate 'civilisation' through their whānau, hapū, and wider-iwi. ${ }^{113}$ The 'civilised' European role models of Grey's police force were necessarily recruited from the 'lower classes' of European society. As a result, among the 'civilised' European behaviours Māori policemen were introduced to were consuming large quantities of alcohol, cavorting with prostitutes, and engaging in other 'undesirable' activities. ${ }^{114}$ As with the Port Phillip Native Police, gauging the success of the 'civilisation' aim depends on one's definitions of 'civilised' and 'uncivilised' behaviours.

Nevertheless, in 1849 Grey reported with regard to the policy of 'civilising' rangatira by employing them as police: 'probably no measure has been so totally successful in its results'. ${ }^{115}$ As with his correspondence regarding the Northern War, the governor greatly exaggerated, even lied, to the colonial office regarding Māori police. E.J. Eyre, lieutenant-governor of New Munster under Grey, wrote of his superior in a private letter that he conducted

\footnotetext{
112 New Zealander, 31 July 1847, p.2

113 Hill, Introducing Policing, pp.11-12; Hill, Policing the Colonial Frontier, i:pp.235-335; Hill, 'The control of both races', pp.6-9

114 Hill, Policing the Colonial Frontier, i:pp.238-240, 269 \& 374-375; Hill, 'Maori Police Personnel', p.184; Hill, Introducing Policing, p.12; Hill, 'Maori Police in Nineteenth Century New Zealand', pp.5456; Hill, 'The control of both races', pp.6-9

115 cited in Hill, 'Maori Police Personnel', p.185; Hill, Introducing Policing, p.13; Hill, 'The control of both races', pp.11-12
} 
his governorship 'with much distortion, some absolute untruths, great rancour, malicious insinuations, sinister suggestions - all calculated to impress a person at a great distance unacquainted or only partially acquainted with the facts'. ${ }^{116}$ Grey had, of course, enacted the policy of employing Māori police, so the perceived success of the experiment reflected well on the governor.

Grey's employment of Native Police drew on his colonial experiences in Ireland, South Australia, and Western Australia. ${ }^{117}$ He had also expressed a desire to establish a Native Police Corps akin to that of the Port Phillip District in New Zealand, but did not persevere with the idea. Although he was in many ways attracted to the notion of a wholly indigenous force serving under British command, Grey was concerned about what he perceived to be the 'warlike' nature of Māori. Moreover, Pākehā settlers had already expressed alarm at the idea of Māori armed by colonial officials. ${ }^{118}$

Much of the widespread Pākehā opposition to the employment of Māori police was based upon an aversion to the idea that Europeans might be policed by Māori - the 'unfortunate prejudice which all Englishmen have to a dark skin' as Grey himself termed it. ${ }^{119}$ Other opposition stemmed from the belief that training Māori in organised coercive violence was a dangerous strategy. At the introduction of the Constabulary Bill a number of Legislative Council members objected to the employment of Māori police on the grounds that Europeans 'might suffer unjust inconvenience at the hands of the constables' $^{120}$ A writer for the Daily Southern Cross later pointed to an incident in the Cape Colony in which it was alleged that 'Kaffir Police ... lured the Brit-

\footnotetext{
116 Eyre to Godley, 22 August 1852, cited in McLintock, p.404n

117 Hill, Policing the Colonial Frontier, i:pp.235-241; Gump, p.92

118 Ward, Show of Justice, p.75; Hill, Policing the Colonial Frontier, i:pp.239-240

119 cited in Hill, 'Maori Policing', p.55

120 NZSCSG, 11 November 1846, p.3; Wellington Independent, 21 November 1846, p.4; Nelson

Examiner and New Zealand Chronicle, 12 December 1846, p.162
} 
ish soldiery into a deadly ambush, and then deserted'. '[W]hat dependence can be reposed on savages! - Train them to European discipline that they may turn and destroy their teachers?', the writer asked, before recommending 'such admirers of an intelligent native police, to lay such warnings seriously to heart' ${ }^{121}$

In May 1846 a correspondent using the pseudonym 'Forethought' had written to the editor of the New Zealander on the proposed formal establishment of a Māori police force, which had been much discussed in recent issues of the newspaper. Forethought considered the proposal to be 'a most dangerous and unwise experiment', and declared 'a more injudicious measure could not be devised'. The author believed that although only a relatively small number of Māori were to be armed and trained, '[n]o sooner do they leave the parade, than the drill, which they have just gone through ... no sooner do they fancy themselves perfect, than their greatest delight is to teach all to their friends, not in the service'. By this measure, Forethought feared, 'we shall very soon have morning drill and parade, in every pah, and if, perhaps they do not become so perfectly disciplined, as Europeans, they will learn how to act, with order, in bodies, and how to support each other, by coolness and regularity in their movements'.

'The New Zealander has already proved himself a most formidable foe, - in his own wilds and fastnesses; - and he only requires a little discipline and practice to make him equally so, - in the open field, - to regular troops', the correspondent further asserted, recalling the recent Northern War. 'New Zealand is not an Indian Empire; - but quite the reverse, in every respect', Forethought wrote, declaring that sepoys were effective in India because of 'the numerous, distinct, religious sects and different castes' in the subconti-

${ }^{121}$ Daily Southern Cross, 29 April 1851, pp.3-4, emphasis in original 
nent, compared with a perceived homogenous Māori. In a rare recognition of the paradox involved in simultaneously utilising and suppressing Māori violence, Forethought concluded by asserting that the proposal to arm and train Māori police was contradictory. Secretaries of state for the colonies Glenelg, Normanby, Russell, and Stanley had all professed 'that every means possible should be taken to allay the warlike propensities of the natives, and to introduce among them the arts and blessings of peace - and those social virtues and habits which Christianity inculcates', the writer declared. 'But, now ... the natives are to be taught, by the Government, - the art of war!!'122

Despite some public opposition, the Constabulary Bill was passed by the Legislative Council - effectively a rubber stamp administration for Governor Grey - on 7 October 1846, and Māori continued to be employed as police. The utilisation of Māori as police was maintained in the face of opposition at least in part because the wages offered to police, although higher than that of preceding forces, were so low that Pākehā - who could earn twice as much per diem doing the most unskilled of labouring work - were reluctant to enrol as police. Māori on the other hand, who were less able to secure said labouring work and who had strong whānau and hapū economic support networks on which to draw, often proved willing police. ${ }^{123}$

Upon the passing of the Constabulary Bill, a writer for the New Zealander acknowledged the limited success already experienced in the employment of Māori police in Wellington. This success arose, however, the writer believed, because the Māori police were of different iwi to those whom they were policing, whose iwi were 'natural enemies' to the Māori police. 'Let those men', the author declared,

\footnotetext{
122 Forethought to the editor, New Zealander, 30 May 1846, p.3, emphasis in original

123 Hill, Policing the Colonial Frontier, i:p.122
} 
or let the Natives who form a part of the Auckland branch, be required to act against their friends, and then, if they do so willingly, and with effect, we shall become converts to the opinion of His Excellency. But until we witness the success of such an experiment, we cannot, with our knowledge of the Native character, but regard this measure as a visionary scheme - expensive in its maintenance, and demoralizing in its tendency. ${ }^{124}$

This reflected a general feeling among a Pākehā public suspicious of relying on Māori to police members of their own tribe according to British law.

As Hill notes, 'the function of the police - as agents of the ruling powers - is to use non-negotiable coercive force upon the populace'. ${ }^{125}$ In theory, Grey's armed police would, in part, utilise Māori violence, or the threat of it, to control Māori. In practice, however, the reality was far from what the governor had hoped to achieve. Grey's policing units arrested both Māori and Pākehā suspects. The crimes the arrestees were suspected of were largely intraPākehā, Pākehā-Māori, or Māori-Pākehā disputes. Internecine Māori 'crime' continued to be 'policed' by Māori rangatira, separate from Pākehā governance. The utilisation of Māori violence was almost wholly related to MāoriPākehā disputes. In the rare instances where internecine Mãori violence was policed, it was in the fledgling Pākehā townships on the colonial frontier. Moreover, the standing in Māori society of a suspect, and their relationship to the arresting officer, were important factors in whether Māori were arrested or not. And many of the Māori enlisted in the armed police, particularly in the smaller Pākehā townships, were young rangatira with ties to many people in their districts. ${ }^{126}$ In the provinces of Auckland and Welling-

\footnotetext{
124 New Zealander, 10 October 1846, p.2

125 Hill, 'The control of both races', p.3

126 Hill, Policing the Colonial Frontier, i:pp.365-366; Hill, 'Maori Policing', pp.54-60; Ward, Show of Justice, pp. 75 \& 143; Belich, Making Peoples, p.192
} 
ton Māori police continued to be employed into the 1850 s. ${ }^{127}$ Internecine Māori violence remained, however, almost exclusively regulated by Māori, free from Crown intrusion.

In 1857 a group of Taranaki settlers voiced their opinion on an offer by Thaia Te Kirikumara, rangatira of the Otaraua hapū of Te Ātiawa, to sell land to the Pākehā. The settlers expressed doubt as to his standing among his iwi, having heard was 'a man of no influence'. 'We do not know what degree of chieftanship [sic] he holds among the Natives, and, moreover, care not', it was reported in the Taranaki Herald. 'Sufficient for us is that he is at the head of the "Progress Party," and the open friend of the Pakeha.'128 In open defiance of te Tiriti o Waitangi, the Crown too came to accept this view. Amid increasing demand for land from Pākehā in Taranaki, Māori opinion was often divided regarding whether to sell or not. Encouraged by land-hungry settlers who supported the 'land-sellers', differing opinions within Te Ātiawa led to violent intra-iwi conflict between 1854 and 1859, which Sinclair described as 'a Maori civil war'. ${ }^{129}$ The Crown took advantage of this internecine Māori violence, using the conflict to secure more land for Pākehā settlers.

\footnotetext{
127 On Māori police from the 1850s onwards see: Hill, Policing the Colonial Frontier, parts i \& ii; Richard S. Hill, The Colonial Frontier Tamed: New Zealand Policing in Transition, 1867-1886, Wellington:1989; Richard S. Hill, The Iron Hand in the Velvet Glove: the Modernisation of Policing in New Zealand, 1886-1917, Wellington:1995; Richard S. Hill, 'The Policing of Colonial New Zealand: from Informal to Formal Control, 1840-1907', in David M. Anderson and David Killingray (eds.), Policing the Empire: Government, Authority and Control, 1830-1940, Manchester:1991, pp.52-70; Hill, 'Maori Police Personnel', pp.174-188

128 Taranaki Herald, 2 May 1857, p.2

129 Sinclair, Origins, p.125
} 
During the Musket Wars Waikato hapū had attacked Taranaki hapū, driving the latter southwards and occupying land in Taranaki. ${ }^{130}$ Having temporarily resided at Waikanae, Wiremu Kingi Te Rangitake, another Otaraua rangatira, and some 600 of his people, returned to Taranaki in 1848. Te Rangitake was born at Manukorihi pā on the north bank of the Waitara. In May 1840 he had signed te tiriti and was soon after baptised, taking the name Wiremu Kingi. As Waikato Māori still occupied his old lands on the northern bank of the Waitara, Wiremu Kingi settled on the southern bank of the river.

Orange notes that Wiremu Kingi signed te tiriti at least in part in the hope that a relationship with the Crown, with the promises of mediation and protection made by the kāwana, would aid the return of his hapū from Waikanae to Taranaki. ${ }^{131}$ Upon signing, he spoke to Henry Williams of returning 'to Waitara and Taranaki generally, their former place of residence, or country of their birth'.132 The Ātiawa rangatira had supported the Pākehā in the Southern Wars for the same reasons. He had also met with Colonel Wakefield in 1839, at which time Wakefield claimed to have purchased all the lands in New Zealand between the 39th and 43rd parallels. Whatever the nature of this meeting and of their agreements, Wiremu Kingi met with Wakefield in the hope that doing so would assist the safe return of his hapu to their lands in Taranaki, and believed the Pākehā colonel whom Māori called 'Wide-awake' could assist in achieving this. ${ }^{133}$

\footnotetext{
130 S. Percy Smith, History and Traditions of the Maoris of the West Coast North Island of New Zealand Prior to 1840, New Plymouth:1910, pp.487-497; Hadfield to his mother, 4 April 1848, Barbara Macmorran, Octavius Hadfield, Wellington:1969, pp.191-192

131 Orange, Treaty of Waitangi, p.89

132 quoted in Carleton, ii:p.17

133 Wakefield, i:p.91; Sinclair, Origins, pp.111-112; Angela Ballara, 'The Pursuit of Mana? A ReEvaluation of the Process of Land Alienation by Maoris, 1840-1890', JPS, 91:4, 1982, p.523; Wiremu Kingi to FitzRoy, 8 June 1844, AJHR, 1861, Session I, E-01, pp.19-20; Benjamin Wells, The History of Taranaki: a Standard Work on the History of the Province, New Plymouth:1878, pp.180-181
} 
Problems within Te Ātiawa arose when a number of rangatira, including Rāwiri Waiaua, Ihaia Te Kirikumara, and Te Teira Manuka, indicated a willingness to sell land to Pākehā. The sale of Taranaki land was strongly opposed by other Te Ātiawa rangatira, including Te Wiremu Katatore and Wiremu Kingi. Reasons for the willingness to sell land were complex. Regardless of Māori motives, however, Pākehā settlers and colonial officials utilised Māori disputes to secure more land.

In August 1855 a Taranaki Herald correspondent noted of New Plymouth: '[t]welve months since there was not a single fortified pa in its neighbourhood: count them now!' The writer continued by bemoaning the increasing numbers of 'distant natives' who were arriving in Taranaki to join the conflict. 'What would the Native be without us?', the writer asked, referring to the benefits of 'civilisation', before asserting: 'the land they hoard beyond any possible requirements of their race lies waste and useless, while millions of our countrymen are scantily fed at famine prices in adjacent colonies, who might be supplied with all the necessities of life cheaply; diminishing misery, and reducing crime, were but a tithe of it under European cultivation'. '[I]S not all this' the correspondent concluded, 'inseparably bound up with the prosperity and elevation of the Native race here?'134

The chief commissioner of the Native Purchase Department, Donald McLean, was despatched to Taranaki by Acting-Governor Colonel Robert Wynyard. McLean was to inform Te Ātiawa that as their feud was a wholly Māori affair, the Crown would not get involved so long as the dispute remained internecine. Upon Browne's arrival in the colony, however, he requested Bishop George Augustus Selwyn to mediate between the feuding Taranaki

${ }^{134}$ Taranaki Herald, 29 August 1855, p.2 
hapū. Despite McLean's earlier assertion of Crown neutrality, the killing of Rāwiri Waiaua for proposing to sell land to the Crown would not be ignored. In 1858 the Executive Council announced that any Māori found fighting upon land the Crown considered to have been purchased by Pākehā would be deemed rebels and treated as such.

While the Crown, ill-equipped to effectively suppress the fighting, initially indicated a reluctance to become involved in te Ātiawa feud, Pākehā settlers at New Plymouth sought to take advantage of the internecine conflict. Ignoring the role that their pressure to sell had played in the 1854 outbreak of the feud, settlers blamed Māori fighting on a 'land league', which they claimed killed any Māori who attempted to sell land. A Taranaki Herald correspondent reported that Katatore and Wiremu Kingi were 'leagued with the Southern tribes to prevent the sale of land'. The settlers supported Thaia Te Kirikumara, whom one newspaper writer labelled as being in 'enlightened opposition to the league against the sale of land'. ${ }^{135}$ The land-hungry Pākehā sent shot, powder, and medical supplies to Te Kirikumara, and further demanded the Crown crush those opposed to land sales. If they did not, the settlers threatened, they might-well join the Māori feud on this side of the 'land sellers'. ${ }^{136}$ Regardless of whether a 'land league' actually existed or not, ${ }^{137}$ the Crown found it increasingly difficult to convince Te Ātiawa to sell Taranaki land. Ihaia Te Kirikumara, for his part, convinced settlers that

135 ibid., 23 May 1855, pp.2-3; see also: 29 August 1855, p.2; C.W. Richmond to T. Richmond, 27 August 1855, Guy H. Scholefield (ed.), The Richmond-Atkinson Papers, 2 vols., Wellington:1960, i:p.177

${ }^{136}$ Sinclair, Origins, pp.126-134

137 A point of much historiographical debate, largely over differing opinions on the definition of a 'league'. Sinclair concluded a 'Taranaki Land League' probably did not exist; Sinclair, Origins, pp.126134; Keith Sinclair, 'Te Tikanga Pakeke: the Maori Anti-Land-Selling Movement in Taranaki, 1849-59', in Munz (ed.), pp.77-92; Keith Sinclair, The Maori Land League: an Examination into the Source of a New Zealand Myth, Auckland:1950; see also: B.J. Dalton, War and Politics in New Zealand, 18551870, Sydney:1967, pp.62-63; M.P.K. Sorrenson, '[Review of] Hill, Edward: There Was a Taranaki Land League', JPS, 80:1, 1971, pp.136-137; cf. Edward Hill, There Was a Taranaki Land League, Wellington:1969 
Wiremu Kingi was an agent of the Ngāti Ruanui land league - probably a false accusation, but one which Pākehā readily accepted.

As early as 1844, McLean had, in his capacity as sub-protector of Aborigines, investigated settler claims to have purchased land in Taranaki. He was told by Māori with regard to Waitara that: 'they had never consented to a sale of any portion of their lands in that neighbourhood'. 'The river has always been a favourite resort of the Natives', McLean wrote. 'It is not probable that the Natives will be inclined to dispose of any of their lands in this particular neighbourhood.'138 Despite this, McLean spent more than a decade trying to secure land on the Waitara for Pākehā settlement. ${ }^{139}$ 'More land is all the cry here but the Waitara natives still hold out' wrote Henry Robert Richmond to his brother from Taranaki in April 1851. ${ }^{140}$

By the mid-1850s, colonial officials believed there to be in Taranaki 'at least five natives in arms against the sale of land for each one who is in favour of it' ${ }^{141}$ As Sinclair has shown, the best chance colonial officials had of purchasing further land in Taranaki was by fuelling disunity within Te Ātiawa, with the hope that those favouring sale became a majority, as had happened with the Bell Block purchase in 1848. ${ }^{142}$ As McLean wrote in November 1849, the Crown had 'to encourage and countenance those natives favourable to the disposal of land, as their being overlooked might close up the field for future negotiations' ${ }^{143}$ This Crown support and toleration in effect utilised Māori violence.

\footnotetext{
138 McLean to Clarke, 5 August 1855, AJHR, 1861, Session I, E-01, pp.19-20; Adams, Fatal Necessity, p.182

${ }_{139}$ Sinclair, Origins, p.117

140 H.R. Richmond to C.W. Richmond, 20 April 1851, Richmond-Atkinson Papers, i:p.93

141 Taranaki Herald, 19 July 1856, p.2

142 Sinclair, Origins, p.123

143 McLean to col. sec., 9 November 1849, MS-Papers-0032-0003, Object\#1016549, ATL
} 
In February 1859 Wiremu Kingi wrote to Browne and McLean reiterating that the land at Waitara was not to be sold. 'These lands' he declared, 'will not be given up by us into the Governor's or your hands, lest we resemble the sea-birds which perch upon a rock: when the tide flows the rock is covered by the sea, and the birds take flight, for they have no resting place'. 'My word is not a new word, it is an old one', he continued, noting that he had told the same message he was now telling Browne to governors Hobson, FitzRoy, and Grey respectively. 'If you hear of any one desiring to sell land' at Waitara, he concluded, 'do not pay attention to it'. ${ }^{144}$

The following month Browne travelled south to Taranaki to meet with Te Âtiawa. At a hui on 8 March the governor declared 'his intention of enforcing British law on British land against Maoris as well as pakehas'. He informed the iwi, through the translation of McLean, that he 'wished them to understand that the Queen regards equally all her British subjects'. He continued: '[ $t$ ]he missionaries had imparted to them the blessings of Christianity and translated the Bible for their use; but, out of regard for the natives, his Excellency had caused an abstract of English law to be translated into Maori'. He declared that '[h]e had no wish to enforce this law', rather 'it would be put in force in those districts where the people are wise enough to desire it, and prepared to carry it into effect themselves'. The governor cited the example of Ngāpuhi as an instance of the perceived success of this policy.

Browne further asserted that had he been in the colony at the time Rāwiri Waiaua was killed by Katatore, he would have arrested the latter, had him tried, and probably hanged him. He did not order Te Ihaia Te Kirikumara arrested, he added, because 'though the murders to which he was a party were horrible and disgraceful, yet they admitted of some extenuation, inas-

144 Wiremu Kingi to Browne and McLean, 11 February 1859, AJHR, 1861, Session I, E-01, p.31 
much as they were committed in retribution for the murder of Rawiri'. 'All this, however, now belongs in the past', the governor announced, before warning that henceforth 'everyman (whether he be Maori or Pakeha) who may commit any violence or outrage within European boundaries shall be arrested and taken before the Judge'. The governor then announced: 'the Maories would be wise to sell the land they cannot use themselves ... but that he never would consent to buy land without an undisputed title'. He added, however, that ' $[\mathrm{h}] \mathrm{e}$ would not permit any one to interfere in the sale of land unless he owned part of it'. This assertion that individual Māori could sell land to the Crown without rangatira consent was a breach of the second article of te tiriti, and, as Walker notes, reflected a colonial strategy of divide and rule. ${ }^{145}$

When McLean had finished translating the kāwana's kōrero, Te Teira stood up, approached the governor, and reiterated his offer to sell land at the mouth of the Waitara, known as the Pekapeka block. Wiremu Kingi, who maintained that Te Teira had no right to sell land at Waitara as he lacked the mana and the support of the iwi necessary to do so, 'got up \& without taking off his hat grunted out "He was god of the Waitara - he was not willing to have land sold." [He then] Called to his men and marched off without saying a civil word all the time'. Browne accepted Te Teira's offer. ${ }^{146}$

The following month the Crown wrote to Wiremu Kingi reiterating that Te Teira had 'offered for sale his piece of land at Waitara'. The offer had been accepted, he was told, as '[t]he Governor's rule is, for each man to have the word (or say) in his own land; that of a man who has not claim will not be

\footnotetext{
145 Walker, pp.113-114

146 Taranaki Herald, 12 March 1859, pp.3-5; A.S. Atkinson, journal, 8 March 1859, RichmondAtkinson Papers, i:p.452
} 
listened to'. ${ }^{147}$ Wiremu Kingi replied: 'I will not agree to our bedroom being sold (I mean Waitara here), for this bed belongs to the whole of us ... You may insist, but I will never agree to it'. 'All I have to say to you, O Governor', he concluded, 'is that none of this land will be given to you, never, never, not till I die'..$^{148}$

The month following the governor's visit to Taranaki saw both a continuation of fighting and hui seeking a peaceful resolution to the dispute. Meanwhile, a delegation of settlers elected by their peers to represent their claims met with the governor and asked him whether he would instruct his colonial officials to purchase land from Māori who could prove clear title, even if others objected to the sale. Browne replied: 'most distinctly Yes'. Specifically mentioning Wiremu Kingi, he continued: 'I will not permit him to exercise his right of chieftainship for the purpose of deterring the rightful owners from selling their land, but if he should have a joint interest in any land offered for sale, his claim will receive due attention, and the land will not be purchased without his consent'. ${ }^{149}$

Colonial officials quickly dismissed Wiremu Kingi's 'joint interest' in the land at Waitara and the sale proceeded. In January 1855 a Daily Southern Cross correspondent had reported from Taranaki: 'all we have to fear here is from what are termed friendly natives ... [t] hey now find themselves likely to be driven in a corner, and they plainly say, when they are, they will drag us into it'. ${ }^{150}$ When surveyors moved onto the disputed land, war broke out at Waitara on 17 March 1860. Thus began, with what G.W. Rusden called 'the

\footnotetext{
147 Te Mete (T.H. Smith) to Wiremu Kingi, 2 April 1859, AJHR, 1861, Session I, E-01, p.31

148 Wiremu Kingi to Browne, 25 April 1859, AJHR, 1861, Session I, E-01, pp.31-32

149 Taranaki Herald, 19 March 1859, p.5

150 Daily Southern Cross, 23 January 1855, p.3
} 
rape of the Waitara', the Taranaki War and the resumption of the New Zealand Wars. ${ }^{151}$

In this chapter, kūpapa and Māori police motivations and actions have been examined and analysed, and the effects of kūpapa participation in the Northern War on the colonisation of New Zealand have been assessed. The Crown's aims and reasons for utilising Māori violence in this manner have also been analysed, as have European responses to this utilisation. The Crown toleration and support of internecine Māori violence to promote land sales in the 1850s has also here been investigated. This understanding of the European utilisation of Māori violence for the promotion of Crown aims illuminates the complex and varied ways in which indigenous agency advanced colonisation in New Zealand.

As Māori-Pākehā conflict erupted in New Zealand a focus on the utilisation of Māori violence came to overlay the earlier focus on attempted suppression. Some settlers believed 'that the quarrels of any two native tribes should be fomented, for our safety - upon the principle - "that two mischievous dogs

\footnotetext{
151 The above section is drawn from: Sinclair, Origins, pp.110-180; Taranaki Herald, 1852-1860; AJHR, 1861, Session I, C-01 \& E-01; Scholefield (ed.), Richmond-Atkinson Papers, i:passim; James Busby, The Pre-Emption Land Question, Auckland:1859; William Martin, The Taranaki Question, Auckland:1860; James Busby, Remarks on a Pamphlet Entitled 'The Taranaki Question', Auckland:1860; Francis Dillon Bell, Thomas Gore Brown, and Frederick Whitaker, Notes on Sir William Martin's Pamphlet Entitled the Taranaki Question, Auckland:1861; Wells, pp.158-185; Richard Taylor, The Past and Present of New Zealand with its Prospects for the Future, London:1868, pp.107-156; Ann Parsonson, 'The Pursuit of Mana', in W.H. Oliver and B.R. Williams (eds.), The Oxford History of New Zealand, Oxford:1981, pp.140-167; Ann Parsonson, 'The Challenge to Mana Māori', in Rice (ed.), pp.167-198; Sinclair, History of New Zealand, pp.112-130; Fargher, Best Man, pp.161-204; Belich, New Zealand Wars, pp.73-88; Belich, Making Peoples, pp.229-235; Hill, Policing the Colonial Frontier, ii:pp.448-468; Ward, Show of Justice, pp.114-124; Dalton, passim; G.W. Rusden, History of New Zealand, 3 vols., London:1883, i:pp.613-634; Ballara, 'Pursuit of Mana?', pp.519-541; Orange, Treaty of Waitangi, pp.144-145; Claudia Orange, 'The Covenant of Kohimarama: a Ratification of the Treaty of Waitangi', NZJH, 14:1, 1980, pp.61-82
} 
were better set upon each other, than allowed to fall upon a man's leg"'. ${ }^{152}$ While the British attempted to direct this 'dogfight', they also became involved: 'rebel' Māori fell upon the British leg, and mangled it pretty badly too. Without kūpapa assistance, however, it may well have been more than just a mangled leg the British suffered. Through the use of kūpapa, the employment of Māori police, and the support of land-selling Māori, the successful colonisation of New Zealand relied on the utilisation of Māori violence.

Māori, however, had their own reasons for allying with the Crown. While Europeans utilised Māori violence in the promotion of colonisation, Māori who allied with the Crown did so to further their hapū or iwi aspirations, thus simultaneously utilising European violence in the promotion of Māori objectives.

152 NZSCSG, 16 August 1845, p.4 


\section{Conclusion}

While violence was not the only aspect of Māori and Aboriginal societies to which Europeans responded, violence dominated European perceptions of the indigenous peoples of the Tasman world from first contact to the middle of the nineteenth century. Like Elsdon Best, European commentators told 'of red war and little else' when writing of Māori and Aboriginal peoples of New South Wales during this period.

Using comparative case studies and examining transnational people and ideas, this thesis has traced the development of European responses to indigenous internecine violence in the Tasman world, from initial conceptualisations, through attempts at suppression, to the utilisation of indigenous violence in the promotion of colonisation.

Based on a long-standing fear of cannibalism, Europeans expected to encounter cannibalistic monsters when they entered the Pacific. Māori were quick to recognise European's simultaneous fear of and fascination with cannibalism, and were quick to flaunt their cannibalism and other violent customs to their own advantage. Māori also flaunted internecine violence to remind Pākehā that they were in Aotearoa on Māori terms, and that Māori held the balance of power in Māori-Pākehā relations. Through both Māori and European agency, the image of Māori circulating in Europe in the lateeighteenth and early-nineteenth centuries was one of violent, cannibal 'savages'.

Having conceptualised Māori as violent, cannibal 'savages', the Endeavour crew sought to discover the warlike nature of Aboriginal peoples of New 
South Wales. Despite the initial confused nature of the Endeavour crew's reports on Aboriginal violence, Aborigines too were soon conceptualised as violent, cannibal 'savages'. European expectations of Aboriginal cannibalism were seemingly reinforced by Aboriginal accusations that other Aborigines were cannibals. The ready acceptance by Europeans of these accusations, combined with confusion surrounding certain Aboriginal customs, was fuelled by the European fear of and fascination with cannibalism and compounded rumours of Aboriginal cannibalism.

The portrayal of Aborigines as cannibals ran through the nineteenth century and into the twentieth. Such assertions served a multitude of functions. Evangelicals claimed existing Aboriginal cannibalism in seeking to fund missions, and former Aboriginal cannibalism to signify missionary success. Settlers avowed Aboriginal cannibalism in order to justify colonisation. If Aborigines could be confirmed as 'savages', then any guilt as to the displacement inherent in colonisation could be eased.

Generally, then, Europeans initially conceptualised Māori and Aboriginal peoples of New South Wales as violent, cannibal 'savages'. This conceptualisation was used to justify both colonisation and the related evangelical and colonial administrative attempts to suppress indigenous violence (which was deemed 'uncivilised', unchristian, and therefore unacceptable) as it was viewed both as an impediment to colonisation and, relatedly, as an inhibitor to the 'saving' of indigenous peoples. Colonial officials sought the suppression of indigenous violence in attempting to establish order and promote colonisation, while in their attempts to 'civilise' and Christianise Māori and Aborigines philanthropists, too, sought to suppress violence. 
Aboriginal peoples of New South Wales were encouraged to stop their violent practices from the time of first settlement. Following the publication of the recommendations of the British parliamentary select committee report on indigenous peoples throughout the British Empire, attempts to suppress Aboriginal violence in New South Wales intensified, specifically through the establishment of an Aboriginal Protectorate. While both protectors and evangelical missionaries attempted to suppress Aboriginal violence, which was increasing in the wake of European settlement, these philanthropists often in fact further exacerbated inter-language group violence. Pastoralism drove Aborigines into foreign country, while Europeans also drew Aborigines through and into foreign country. Contact - both through indigenous and European agency - brought together language groups traditionally hostile to one another and thus drastically increased Aboriginal violence.

Finding their efforts to suppress Aboriginal violence using Aboriginal peoples' supposed status as British subjects who were subject to British law frustrated, protectors and missionaries sought to suppress Aboriginal violence by 'civilising' and Christianising them. Thus a paradox developed: to 'civilise' and Christianise Aborigines philanthropists had to suppress Aboriginal violence, which they sought to do by 'civilising' and Christianising Aborigines.

Beginning with the visit of Tupaia and the crew of the Endeavour, Māori, too, were encouraged to cease their violent tikanga. Evangelical missionaries saw Māori violence as a chief barrier to their 'civilisation' and Christianisation, and insisted Māori cease practising both kaitangata and utu-seeking tauā. Success in this attempted suppression was not achieved, however, until Māori themselves desired peace, a desire which was occasioned by the saturation of muskets which removed the arms advantage which had occa- 
sioned the Musket Wars. This saturation of arms led to Māori desiring missionary-mediated peace, as evangelical mediation enabled an even adoption of peace and allowed mana to be preserved by both sides. Thus, while a saturation of muskets ended the Musket Wars, it was Māori-requested missionary mediation which facilitated the end of the conflicts. Colonial officials were later used by Māori in a similar manner.

From 1833 colonial officials began to attempt to interfere in Māori violence, and from 1840 the Crown demanded Māori give up cannibalism and 'human sacrifice', as they were declared to be British subjects. Using the sovereignty it asserted under the Treaty of Waitangi, through the establishment of a Protectorate similar to that in operation in Port Phillip the Crown sought to suppress Māori violence.

Māori responses to European attempts to suppress violence were complex. The suppression of cannibalism was achieved relatively quickly. Once Māori saw how detrimental the image of them as cannibals was to the Pākehā trade they sought, they soon abandoned, or at least hid, the practice. Both those Māori whose rangatira had signed te Tiriti o Waitangi and those who had not, however, maintained they were able to continue to resolve their disputes through traditional tikanga, free from Crown interference, even if violence was involved.

While Māori and Aboriginal violence was seen as a barrier to colonisation, it was also further simultaneously used by Europeans to promote the colonisation of the Tasman world. At the same time as Europeans sought the suppression of internecine Aboriginal violence, colonists demanded protection from Aboriginal violence while philanthropists demanded protection for Aborigines. The Crown combined these two demands to form the Native 
Police Corps, which would protect settlers by punishing and preventing Aboriginal 'outrages' while simultaneously 'civilising' and Christianising Aborigines. Those Aborigines who worked for the Crown had their own reasons for doing so. While their violence was being utilised, they too were utilising the power their relationship with the Crown brought.

In New Zealand, too, attempts to suppress Māori violence were concurrent with Crown attempts to utilise Māori violence. Māori were encouraged to fight against other iwi or hapū who were at war with the British. Māori were also employed to police other Māori. And Māori who supported land sales were aided by the Crown in their conflict with those Māori opposed to selling land to Pākehā. Like the Port Phillip Native Police troopers, those Māori whose violence was utilised by the Crown were willing partners, and had their own motivations for their alliance. The history of the European utilisation of indigenous violence in the Tasman world is one of mutual exploitation.

In both New Zealand and New South Wales, as elsewhere in the British Empire, the Crown actively utilised indigenous violence to promote colonisation. This utilisation was the culmination of European reactions to indigenous violence, which began with the conceptualisation of violent 'savages' and developed into attempts to suppress indigenous hostility, before being overlaid by the utilisation of both Māori and Aboriginal violence.

The contribution of this thesis lies in conducting comparative case studies in order to interrogate European attitudes to and relations with the indigenous peoples of the Tasman world between 1769 and the 1850s. Whereas extant 
historiography has previously addressed European responses to indigenous violence in geographic and temporal isolation (almost wholly within studies not primarily investigating this particular topic), the Tasman world comparison offered here enhances knowledge of these responses. This augmented understanding of European responses to indigenous violence enables a better awareness of the processes of the colonisation of the Tasman world. This violence-focussed interpretation has aided a better understanding of colonisation because perceptions of and reactions to indigenous violence dominated the European actions which shaped colonisation.

This study has highlighted and analysed the paradox that while many Europeans, including many colonial officials who worked with indigenous peoples, wrote of heterogeneous groups of Māori and Aborigines, administrators responsible for colonial policy often wrote of a homogeneous Māori and a homogeneous Aboriginal peoples of Australia. When they issued colonial policies based on this perceived homogeneity, their actions often exacerbated the very indigenous violence they sought to suppress. Meanwhile, the Crown concurrently willingly utilised the heterogeneous nature of Māori and Aboriginal peoples, forming alliances with some groups to make use of their traditional enmity with others to promote colonisation.

The other paradox central to this study, that European colonisers simultaneously sought to suppress and utilise indigenous violence, has rarely been historiographically acknowledged in the Tasman world, despite Europeans having long utilised indigenous violence in the pursuit of empire, particularly with regard to suppressing indigenous resistance. The British Empire, which at its zenith covered some 11.5 million square miles and ruled, nominally at least, over a quarter of the world's population, relied heavily on colonised peoples to further colonisation. The comparative analysis of this 
paradox offered here has allowed for the investigation to be posited within the wider-British Empire, and greatly aids understanding of the Crown colonial policy of divide and rule. This in turn reveals the complexities of colonial governance and authority in the Tasman world. Moreover, analysis of indigenous agency within this imperial strategy of divide and rule further reveals important new understandings regarding how Māori and Aboriginal individual and group actions were an integral part of the colonisation of the Tasman world.

European attitudes and responses to indigenous peoples of the Tasman world were largely shaped by the belief that they were violent, cannibal 'savages'. This belief had a pervasive influence on the processes of colonisation in the Tasman world, as Europeans responded to indigenous internecine violence in a variety of ways, including the construction of an image of violence to depict 'savagery' thus 'justify' colonisation, and the attempt to simultaneously suppress and utilise Māori and Aboriginal violence in Christianising and 'civilising' the indigenous peoples of the Tasman world. 


\title{
Select Bibliography
}

\author{
Primary Sources
}

\section{Unpublished Works}

'Aboriginal Protectorate Records', VPRS-13172, PROV

'Aboriginal Protectorate Weekly, Monthly, Quarterly and Annual Reports and Journals', VPRS-4410, PROV

Black, Niel, journal, MS-11519:Box-99/1, SLV

Bridge, Cyprian, 'Journal of an Expedition to New Zealand', MS-0257-MS-0258, ATL

Brown, A.N., journals and letterbook, micro-MS-0030, ATL

Clarke, George, letters and journals, qMS-0463-qMS-0469, ATL

-, inwards letters, MS-Papers-0032-0215, ATL

-, transcribed letters, MS-Papers-7394, ATL

Dredge, James, diary, MS-5244, SLV

'Instructions of the Committee of the Church Missionary Society, delivered August 6, 1822, to the Rev. Henry Williams, proceeding as a missionary to New Zealand: with Mr. Williams's reply and an address by the Rev. Edward Garrard Marsh, v.081, HL

'Inward Registered Correspondence to the Superintendent of Port Phillip', VPRS-19, PROV

'Inward Registered Correspondence to the Superintendent of Port Phillip, Relating to Aboriginal Affairs', VPRS-10, PROV 
King, John, letters and journals, MS-73, HL

McLean, Donald, papers, MS-Papers-0032-0001, ATL

‘Native Land Purchase Commissioner Papers', MS-Papers-0032-0003, ATL

Robinson, George Augustus, journal, MS-9974, SLV

-, 'Chief Protector of Aborigines' Outward Letter Book', VPRS-2895, PROV

Shortland, Edward, journal, micro-MS-0356, ATL

Taylor, Richard, journals, qMS-1984-qMS-1999, ATL

-, inwards letters, MS-Papers-0032-0600, ATL

Tuckfield, Francis, journal, MS-7667:Box-665, SLV

'Unregistered Correspondence Relating to the Dismissal of W. Le Souef', VPRS-4398, PROV

'Unregistered Inward Correspondence to the Chief Protector of Aborigines Reports and Returns', VPRS-11, PROV

Williams, William, journals, qMS-2248-qMS-2251, ATL

Yate, William, journal and diary, MS-2544/MS-copy-micro-0453, ATL 


\section{Published Works}

Aborigines (Australian Colonies): Return to an Address of the House of Commons, Dated 5 August 1844 for, Copies or Extracts from the Despatches of the Governors of the Australian Colonies, with Reports of the Protectors of Aborigines, and any other Correspondence to Illustrate the Condition of the Aboriginal Population, London:1844, SLV

Appendices to the Journals of the House of Representatives

Banks, Joseph, The Endeavour Journal of Joseph Banks, 1768-1771, Beaglehole, J.C. (ed.), 2 vols., Sydney:1962

Barrington, George, The History of New South Wales [1802], second edition London:1810

Bates, Daisy, The Passing of the Aborigines: a Lifetime Spent among the Natives of Australia [1938], second edition London:1966

-, Tales Told to Kabbarli: Aboriginal Legends Collected by Daisy Bates, Wilson, Barbara Ker (ed.), London:1972

Baylie, W.H., 'Remarks and Observations on the Habits and Customs of the Aborigines of the Western Port District, in the Province of Australia Felix', Port Phillip Magazine, 1:1, 1843, pp.34-44

Bell, Francis Dillon, Browne, Thomas Gore, and Whitaker, Frederick, Notes on Sir William Martin's Pamphlet Entitled the Taranaki Question, Auckland:1861

Best, Elsdon, 'Maori Agriculture: Cultivated Food-Plants of the Maori and Native Methods of Agriculture', JPS, 39:4, 1930, pp.346-380

-, Tuhoe: Children of the Mist [1925], second edition Wellington:1972

-, The Maori, 2 vols., Wellington:1924 
-, 'Notes on the Art of War, as Conducted by the Maori of New Zealand [Part I]', JPS, 11:1, 1902, pp.11-41

-, 'Omens and Superstitious Beliefs of the Maori, Part I', JPS, 7:3, 1898, pp.119-136

Boultbee, John, Journal of a Rambler: the Journal of John Boultbee, Starke, June (ed.), Auckland:1986

Bride, Thomas Francis (ed.), Letters from Victorian Pioneers: a Series of Papers on the Early Occupation of the Colony, the Aborigines, Etc. [1898], Melbourne:1983

British Parliamentary Papers (Irish University Press Series), Colonies, New Zealand, 17 vols., Shannon:1968-1971

Bunbury, Thomas, Reminiscences of a Veteran Being Personal and Military Adventures in Portugal, Spain, France, Malta, New South Wales, Norfolk Island, New Zealand, Andaman Islands, and India, 3 vols., London:1861

Burrows, Robert, Extracts from a Diary kept by the Rev. R. Burrows during Heke's War in the North in 1845, Auckland:1886

Busby, James, The Pre-Emption Land Question, Auckland:1859

Cannon, Michael (ed.), Historical Records of Victoria, Volume 7: Public Finance of Port Phillip, 1836-1840, Melbourne:1998

- (ed.), Historical Records of Victoria, Volume 2B: Aborigines and Protectors, 1839-1839, Melbourne:1983

- (ed.), Historical Records of Victoria, Volume 2A: the Aborigines of Port Phillip, 1835-1839, Melbourne:1982

Carey, Hilary M., and Roberts, David A. (eds.), The Wellington Valley Project. Letters and Journals Relating to the Church Missionary Society Mission to Wellington Valley, NSW, 1830-45. A Critical Electronic Edition, 2002 
Carver, J., The New Universal Traveller, Containing a Full and Distinct Account of all the Known Empires, Kingdoms, and States, in the Known World, London:1779

Clarke, George, Extracts from the Final Report of the Chief Protector of Aborigines in New Zealand, Auckland:1846

Clarke (junior), George, Notes on Early Life in New Zealand, Hobart:1903

-, 'George Clarke Remembers: Three Letters Written by George Clarke, in 1904, to Dr. T.M. Hocken, of Dunedin', Waikato-Auckland Historical Journal, 55, 1989, pp.25-29

Coates, Dandeson, The New Zealanders and their Lands: the Report of the Select Committee of the House of Commons, on New Zealand, Considered in a Letter to Lord Stanley, London:1844

-, Documents Exhibiting the Views of the Church Missionary Society on the New Zealand Question, and Explanatory of the Present State of that Country, London:1839

Colenso, William, The Authentic and Genuine History of the Signing of the Treaty of Waitangi [1890], Christchurch:1971

-, Fifty Years Ago in New Zealand. A Commemoration: a Jubilee Paper: a Retrospect: a Plain and True Story, Napier:1888

Collins, David, An Account of the English Colony in New South Wales, from its First Settlement in January 1788, to August 1801 [1802], second edition London:1804

Cook, James, The Journals of Captain James Cook on his Voyages of Discovery, Beaglehole, J.C. (ed.), 4 vols., Cambridge:1955-1974

-, Captain Cook's Journal during his First Voyage, Wharton, W.J.L. (ed.), London:1893 
Crozet, Julien Marie, Crozet's Voyage to Tasmania, New Zealand, the Ladrone Islands, and the Philippines in the Years 1771-1772, Roth, Henry Ling (translation), London:1891

Cruise, Richard A., Journal of a Ten Months' Residence in New Zealand, London:1823

Cunningham, P., Two Years in New South Wales, 2 vols., London:1827

Curr, E.M., The Australian Race: Its Origin, Languages, Customs, Place of Landing in Australia, and the Routes by Which it Spread Itself Over that Continent, 4 vols., Melbourne:1886-1887

-, Recollections of Squatting in Victoria, then called the Port Phillip District (from 1841 to 1851) [1883], Melbourne:1965

Darwin, Charles, Journal of Researches into the Geology and Natural History of the Various Countries Visited by H.M.S. Beagle, London:1839

Defoe, Daniel, The Life and Strange Surprizing Adventures of Robinson Crusoe [1719], New York:1963

Dredge, James, Brief Notices of the Aborigines of New South Wales, Including Port Phillip, in Reference to their Past History and Present Condition, Geelong:1845

Dunderdale, George, The Book of the Bush: Containing many Truthful Sketches of the Early Colonial Life of Squatters, Whalers, Convicts, Diggers, and Others who Left their Native Land and Never Returned [1870], Melbourne:1973

Earle, Augustus, A Narrative of Nine Months' Residence in New Zealand, in 1827, London:1832

Elder, J.R. (ed.), Marsden's Lieutenants, Dunedin:1934

FitzRoy, Robert, Remarks on New Zealand, in February 1846, London:1846 
-, Narrative of the Surveying Voyages of His Majesty's Ships Adventure and Beagle [1839], 2 vols., New York:1966

Forster, George, A Voyage Round the World [1777], Thomas, Nicholas, and Berghof, Oliver (eds.), 2 vols., Honolulu:2000

Forster, J.R., The Resolution Journal of Johann Reinhold Forster, 1772-1775, Hoare, Michael E. (ed.), 4 vols., London:1982

Fox, William, The War in New Zealand [1886], Christchurch:1973

Froude, J.A., Short Stories on Great Subjects, London:1894

Gudgeon, T.W., The Defenders of New Zealand: Being a Short Biography of Colonists who Distinguished Themselves in Upholding Her Majesty's Supremacy in these Islands, Auckland:1887

Hawkesworth, John, An Account of the Voyages Undertaken by the Order of His Present Majesty for Making Discoveries in the Southern Hemisphere, 3 vols., London:1773

Holy Bible, KJV

Home, George, Memoirs of an Aristocrat, and Reminiscences of the Emperor Napoleon, London:1838

Homer, The Odyssey, Rieu, D.C.H. (revised trans.), London:1991

Howitt, A.W., The Native Tribes of South-East Australia, London:1904

-, 'Notes on Australian Message Sticks and Messengers', JAIGBI, 18, 1889, pp.314-332

-, 'On Australian Medicine Men; or, Doctors and Wizards of Some Australian Tribes', JAIGBI, 16, 1887, pp.23-59 
-, 'On Some Australian Ceremonies of Initiation', JAIGBI, 13, 1884, pp.432-459

-, 'On Some Australian Beliefs', JAIGBI, 13, 1884, pp.185-198

Howitt, Richard, Impressions of Australia Felix, during Four Years' Residence in that Colony; Notes of a Voyage Round the World; Australian Poems, Ec., London:1845

McDonnell, Thomas, 'A Maori History: Being a Native Account of the Pakeha-Maori War in New Zealand', in Gudgeon, Defenders of New Zealand, pp.491-530

McNab, Robert (ed.), Historical Records of New Zealand, 2 vols., Wellington:1908 \& 1914

Maning, F.E., Old New Zealand: a Tale of the Good Old Times [1863], Auckland:1930

-, History of the War in the North of New Zealand against the Chief Heke in the Year 1845, told by an Old Chief of the Ngapuhi Tribe, Auckland:1862

Markham, Edward, New Zealand or Recollections of It, McCormick, E.H. (ed.), Wellington:1963

Marmon, John, 'The Life and Adventures of John Marmon, the Hokianga Pakeha Maori; or, Seventy-Five Years in New Zealand', Otago Witness, 25 March-15 April 1882

Marsden, Samuel, The Letters and Journals of Samuel Marsden, 1765-1838, Elder, J.R. (ed.), Dunedin:1932

Mathew, Felton, The Founding of New Zealand: the Journals of Felton Mathew, First Surveyor-General of New Zealand, and his Wife 1840-1847, Rutherford, J. (ed.), Dunedin:1940 
Missionary Register, London:1813-1855

Morgan, John, The Life and Adventures of William Buckley, Hobart:1852

Morrison, James, Journal of James Morrison, Boatswain's Mate of the Bounty, Rutter, Owen (ed.), London:1935

Nicholas, J.L., Narrative of a Voyage to New Zealand [1817], 2 vols., Auckland:1971

Ollivier, Isabel, and Hingley, Cheryl (transcription and translation), Early Eyewitness Accounts of Maori Life, 1: Extracts from Journals Relating to the Visit to New Zealand of the French Ship St Jean Baptiste in December 1769 under the Command of J.F.M. de Surville, Wellington:1987

Ollivier, Isabel (transcription and translation), Early Eyewitness Accounts of Maori Life, 2: Extracts from Journals Relating to the Visit to New Zealand in May-July 1772 of the French Ships Mascarin and Marquis de Castries under the Command of Marion du Fresne, Wellington:1985

Orton, Joseph, Aborigines of Australia, London:1836

Parker, E.S., The Aborigines of Australia, Melbourne:1854, SLV

Polack, J.S., Manners and Customs of the New Zealanders [1840], 2 vols., Christchurch:1976

-, New Zealand: Being a Narrative of Travels and Adventures during a Residence in that Country Between the Years 1831 and 1837 [1838], 2 vols., Christchurch:1974

Report from the Select Committee on Aborigines (British Settlements);

Together with the Minutes of Evidence, Appendix and Index, 2 vols., London:1836-1837

Reynolds, Henry (ed.), Dispossession: Black Australians and White Invaders, Sydney:1989 
Robinson, G.A., The Journals of George Augustus Robinson, Chief Protector, Port Phillip Aboriginal Protectorate, 1839-1852 [1998], Clark, Ian D. (ed.), 6 vols., second edition Ballarat:2000

-, 'In Quest of the Tribes: G.A. Robinson's Unabridged Report of his 1841 Expedition among Western Victorian Aboriginal Tribes; Kenyon's "Condensation" Reconsidered', Clark, Ian D. (ed.), Memoirs of the Museum of Victoria. Anthropology and History, 1:1, 1990, pp.97-129

-, Friendly Mission: the Tasmanian Journals and Papers of George Augustus Robinson, 1829-1834, Plomley, N.J.B. (ed.), Hobart:1966

-, 'George Augustus Robinson's Journey into South-Eastern Australia, 1844', Mackaness, George (ed.), JRAHS, 27:5, 1941, pp.318-349

-, 'The Aboriginal Protectorate of Port Phillip: Report of an Expedition to the Aboriginal Tribes of the Western Interior by the Chief Protector, George Augustus Robinson', Kenyon, A.S. (ed.), VHM, 12:3, 1928, pp.134-171

Savage, John, Some Account of New Zealand; Particularly of the Bay of Islands, and Surrounding Country [1807], Dunedin:1966

Scholefield, Guy H. (ed.), The Richmond-Atkinson Papers, 2 vols., Wellington:1960

Sharp, Andrew (ed.), Duperrey's Visit to New Zealand in 1824, Wellington:1971

Shortland, Edward, Maori Religion and Mythology, London:1882

-, A Short Sketch of the Maori Races, Dunedin:1865

-, Traditions and Superstitions of the New Zealanders [1854], second edition London:1856 
-, The Southern Districts of New Zealand; a Journal with Passing Notices of the Customs of the Aborigines, London:1851

Tasman, Abel, The Voyages of Abel Janszoon Tasman, Sharp, Andrew (ed.), London:1968

Taylor, Richard, The Past and Present of New Zealand with its Prospects for the Future, London:1868

-, Te Ika a Maui, or New Zealand and its Inhabitants, London:1855

Tench, Watkin, Sydney's First Four Years: Being a Reprint of 'a Narrative of the Expedition to Botany Bay', and 'a Complete Account of the Settlement at Port Jackson' [1789 \& 1793], Sydney:1961

Terry, Charles, New Zealand, Its Advantages and Prospects, as a British Colony, London:1842

Thomas, William, 'Brief Account of the Aborigines of Australia Felix', nd, in Bride (ed.), Letters from Victorian Pioneers, pp.398-437

Threlkeld, L.E., Australian Reminiscences \& Papers of L.E. Threlkeld, Missionary to the Aborigines, 1824-1859, Gunson, Niel (ed.), 2 vols., Canberra:1974

-, An Australian Grammar: Comprehending the Principles and Natural Rules of the Language, as Spoken by the Aborigines, in the Vicinity of Hunter's River, Lake Macquarie, Ec., New South Wales, Sydney:1834

Wakefield, Edward Jerningham, Adventure in New Zealand, from 1839 to 1844; with Some Account of the Beginning of the British Colonization of the Islands, 2 vols., London:1845

Watson, Frederick (ed.), Historical Records of Australia, series I, 26 vols., Sydney:1914-1925

White, J., The Ancient History of the Maori, His Mythology and Traditions, 13 vols., Wellington:1887-1891 
Williams, Henry, Plain Facts Relative to the Late War in the Northern District of New Zealand, Williams, William (ed.), Auckland:1847

-, The Early Journals of Henry Williams, Senior Missionary in New Zealand of the Church Missionary Society, 1826-40, Rogers, Lawrence M. (ed.), Christchurch:1961

Williams, William, Christianity Among the New Zealanders, London:1868

-, and Williams, Jane, The Turanga Journals, 1840-1850: Letters and Journals of William and Jane Williams, Missionaries to Poverty Bay, Porter, Frances (ed.), Wellington:1974

Yate, William, An Account of New Zealand and of the Church Missionary Society's Mission to the Northern Island [1835], Wellington:1970 


\section{Newspapers}

Australian

Colonial Times [Hobart]

Colonist [Sydney]

Daily Southern Cross [Auckland]

Melbourne Argus

Nelson Examiner and New Zealand Chronicle

New South Wales Government Gazette

New Zealand Colonist and Port Nicholson Advertiser

New Zealander

New Zealand Gazette and Wellington Spectator

New Zealand Spectator and Cook's Straits Guardian

Port Phillip Gazette, SLV

Port Phillip Patriot and Melbourne Advertiser, SLV

Sydney Gazette and New South Wales Advertiser

Sydney Herald

Sydney Monitor

Sydney Morning Herald

Wellington Independent 


\section{Secondary Sources}

\section{Articles and Chapters}

Adams, Jonathan, 'Governor FitzRoy's Debentures and their Role in his Recall', NZJH, 20:1, 1986, pp.44-63

Anderson, Jim, "“A glorious thing is to live in a tent in the infinite": Daisy Bates', in Cole et al. (eds.), Uncommon Ground, pp.217-231

Arens, W., and Sahlins, Marshall, 'Cannibalism: an Exchange', New York Review of Books, 26:4, 22 March 1979, np

Ballantyne, Tony, 'Race and the Webs of Empire: Aryanism from India to the Pacific', Journal of Colonialism and Colonial History, 2:3, 2001, np

Ballara, Angela, 'The Pursuit of Mana? A Re-Evaluation of the Process of Land Alienation by Maoris, 1840-1890', JPS, 91:4, 1982, pp.519-541

-, 'The Role of Warfare in Maori Society in the Early Contact Period', JPS, 85:4, 1976, pp.487-506

Barta, Tony, "“They appear actually to vanish from the face of the Earth." Aborigines and the European Project in Australia Felix', Journal of Genocide Research, 10:4, 2008, pp.519-539

Barwick, Diane E., 'Mapping the Past: an Atlas of Victorian Clans, 1825-1904, Part I', AH, 8:2, 1984, pp.100-131

-, 'Changes in the Aboriginal Population of Victoria, 1863-1966', in Mulvaney and Golson (eds.), Aboriginal Man and Environment, pp.288-315

Beaver, Dan, '[Review Essay] Flesh or Fantasy: Cannibalism and the Meanings of Violence', Ethnohistory, 49:3, 2002, pp.671-685 
Belich, James, 'Myth, Race, and Identity in New Zealand', NZJH, 31:1, 1997, pp.9-22

-, 'Race and New Zealand: Some Social History of Ideas', Macmillan Brown Lectures, 1994

-, 'Review Article: Hobson's Choice', NZJH, 24:2, 1990, pp.200-207

Bell, Rachael, "“Texts and Translations": Ruth Ross and the Treaty of Waitangi', NZJH, 43:1, 2009, pp.39-58

Bentley, Trevor, 'Acculturating Heavy Metal: the Role of the Tribal Artillery in the New Zealand Musket Wars', New Zealand Legacy, 7:2, 1996, pp. $14-17 \& 21$

Biber, Katherine, 'Cannibals and Colonialism', Sydney Law Review, 27:4, 2005, pp.623-637

Binney, Judith, 'Tuki's Universe', in Sinclair (ed.), Tasman Relations, pp.15-33

-, 'Christianity and the Maoris to 1840: a Comment', NZJH, 3:2, 1969, pp.143-165

Blake, L.J., 'The Native Police Corps', Gipps-Land Gate, 1:3-4, 1971, pp.42-45 \& 56-63

Boyce, James, 'Fantasy Island', in Manne (ed.), Whitewash, pp.17-78

Bridges, Barry, 'The Extension of English Law to the Aborigines for Offences Committed Inter Se, 1829-1842', JRAHS, 59:4, 1973, pp.264-269

-, 'The Native Police Corps, Port Phillip District and Victoria, 1837-1853', JRAHS, 57:2, 1971, pp.113-142

-, 'The Aborigines and the Law: New South Wales 1788-1855', Teaching History, 4:3, 1970, pp.40-42 
Broome, Richard, 'Victoria', in McGrath (ed.), Contested Ground, pp.121-167

-, 'Aboriginal Workers on South-Eastern Frontiers', Australian Historical Studies, 26:103, 1994, pp.202-220

-, 'Aboriginal Victims and Voyagers, Confronting Frontier Myths', Journal of Australian Studies, 18:14, 1994, pp.70-77

-, 'The Struggle for Australia: Aboriginal-European Warfare, 1770-1930', in McKernan and Browne (eds.), Australia: Two Centuries of War \& Peace, pp.92-120

-, '[Review of] Aborigines in Colonial Victoria 1835-86 and Conquest of the Ngarrindjeri', Historical Studies, 19:76, 1981, pp.454-457

Burnett, R.I.M., 'Kupapas', JPS, 74:2, 1965, pp.227-230

Butterworth, G.V., '[Review of] Belich, James: The New Zealand Wars', JPS, 99:2, 1990, pp.211-214

Carey, Hillary M., 'Death, God and Linguistics: Conversations with Missionaries on the Australian Frontier, 1824-1845', Australian Historical Studies, 40:2, 2009, pp.161-177

Clayton, Daniel, 'Captain Cook's Command of Knowledge and Space: Chronicles from Nootka Sound', in Williams, Glyndwr (ed.), Captain Cook, pp.110-133

Cranston, R., 'The Aborigines and the Law: an Overview', University of Queensland Law Journal, 8, 1973-1974, pp.60-78

Cuthill, W.J., 'The White Woman with the Blacks in Gipps' Land', VHM, 31:121, 1961, pp.7-25

D'Arcy, Paul, 'Maori and Muskets from a Pan-Polynesian Perspective', NZJH, 34:1, 2000, pp.117-132 
Darian-Smith, Kate, 'Marking Capture: White Women Captives in Australia', in Damousi and Ellinghaus (eds.), Citizenship, Women and Social Justice, pp.71-78

-, 'The White Woman of Gippsland: a Frontier Myth', in Darian-Smith et al. (eds.), Captured Lives, pp.14-34

Davies, Susanne, 'Aborigines, Murder and the Criminal Law in Early Port Phillip, 1841-1851', Historical Studies, 22:88, 1987, pp.313-335

Douglas, Bronwen, 'Voyages, Encounters, and Agency in Oceania: Captain Cook and Indigenous People', History Compass, 6:3, 2008, pp.712-737

-, 'The Lure of Texts and the Discipline of Praxis: Cross-Cultural History in a Post-Empirical World', Humanities Research, 14:1, 2007, pp.12-30

-, 'Slippery Word, Ambiguous Praxis: "Race” and Late-18th-Century Voyagers in Oceania', JPH, 41:1, 2006, pp.1-29

-, 'Notes on "Race" and the Biologisation of Human Difference', JPH, 40:3, 2005, pp.331-338

-, 'Seaborne Ethnography and the Natural History of Man', JPH, 38:1, 2003, pp.3-27

-, 'Science and the Art of Representing "Savages": Reading "Race" in Text and Image in South Seas Voyage Literature', History and Anthropology, 11:2-3, 1999, pp.157-201

Dredge, Rhonda, "“An awful silence reigns": James Dredge at the Goulburn River', La Trobe Journal, 61, 1998, pp.16-26

Dyer, Colin, 'The Indigenous Australians in Sydney and its Environs as Seen by French Explorers, 1802-1831', JRAHS, 88:2, 2002, pp.147-161 
Elbourne, Elizabeth, 'The Sin of the Settler: the 1835-36 Select Committee on Aborigines and Debates over Virtue and Conquest in the Early Nineteenth-Century British White Settler Empire', Journal of Colonialism and Colonial History, 4:3, 2003, np

Fels, Marie H., 'A Quasi-Policing Aboriginal Expedition in Port Phillip in $1838^{\prime}$, AH, 10:2, 1986, pp.117-129

Ferry, John, 'The Failure of the New South Wales Missions to the Aborigines before $1845^{\prime}, A H, 3,1979$, pp.25-36

Finzsch, Norbert, "'It is scarcely possible to conceive that human beings could be so hideous and loathsome": Discourses of Genocide in Eighteenth- and Nineteenth-Century America and Australia', Patterns of Prejudice, 39:2, 2005, pp.97-115

Fisher, Robin, 'Henry Williams' Leadership of the CMS Mission to New Zealand', NZJH, 9:2, 1975, pp.142-153

Forth, G.S., 'The Pastoral Expansion and the Initial Occupation of "Australia Felix"', JRAHS, 70:1, 1984, pp.19-29

Frost, Alan, 'New South Wales as Terra Nullius: the British Denial of Aboriginal Land Rights', Historical Studies, 19:77, 1981, pp.513-523

Gardner, Peter, 'The Journals of de Villiers and Warman: the Expedition to Recover the Captive White Woman', VHM, 50:2, 1979, pp.89-97

-, 'Massacres of Aborigines in Gippsland, 1840-1850', Historian, 27, 1975, pp.19-24

Gaughwin, Denise, and Sullivan, Hilary, 'Aboriginal Boundaries and Movements in Western Port, Victoria', $A H, 8,1984$, pp.80-98

Greenwood, G.W., 'Reverend Francis Tuckfield's Magnificent Failure at Bunting Dale', Heritage: a Journal of the Methodist Historical Society of Victoria, 6, 1956, pp.3-21 
Grimshaw, Patricia, ‘Maori Agriculturalists and Aboriginal

Hunter-Gatherers: Women and Colonial Displacement in

Nineteenth-century Aotearoa/New Zealand and Southeastern

Australia', in Pierson and Chaudhuri (eds.), Nation, Empire, Colony, pp. $21-40$

Gump, James, 'The Imperialism of Cultural Assimilation: Sir George Grey's Encounter with the Maori and the Xhosa, 1845-1868', Journal of World History, 9:1, 1998, pp.89-106

Head, Lyndsay, 'The Pursuit of Modernity in Maori Society: the Conceptual Bases of Citizenship in the Early Colonial Period', in Sharp and McHugh (eds.), Histories of Power and Loss, pp.97-122

Higginbotham, Ann R., "'Sin of the Age": Infanticide and Illegitimacy in Victorian London', Victorian Studies, 32:3, 1989, pp.319-337

Hill, Richard S., 'Maori Police Personnel and the Rangatiratanga Discourse', in Godfrey and Dunstall (eds.), Crime and Empire, pp.174-188

-, 'Imperial Vision', New Zealand Books, 18:3, 1998, p.17

-, "“The control of both races": the Policing of the Wellington Settlement, 1840-1853', New Zealand Studies, 7:1, 1997, pp.3-13

-, 'The Policing of Colonial New Zealand: from Informal to Formal Control, 1840-1907', in Anderson and Killingray (eds.), Policing the Empire, pp.52-70

-, 'Maori Policing in Nineteenth Century New Zealand', Archifacts, 2, 1985, pp.54-60

Hillier, Alan J., 'The Native Police under Scrutiny', Journal of the Royal Historical Society of Queensland, 15:6, 1994, pp.279-293 
Howe, K.R., '[Review of] Aborigines in Colonial Victoria 1825-86', AH, 4:2, 1980, pp.205-206

-, 'The Maori Response to Christianity in the Thames-Waikato Area, 1833-1840', NZJH, 7:1, 1973, pp.28-46

Hudson, Nicholas, 'From "Nation" to "Race": the Origin of Racial Classification in Eighteenth-Century Thought', Eighteenth-Century Studies, 29:3, 1996, pp.247-264

Hunt, Aeron, 'Calculations and Concealments: Infanticide in Mid-Nineteenth Century Britain', Victorian Literature and Culture, 34:1, 2006, pp.71-94

Hunter, Kate, '[Review of] Remaking the Tasman World', NZJH, 43:2, 2009, pp.216-217

Kercher, Bruce, 'R v Ballard, R v Murrell and R v Bonjon', Australian Indigenous Law Reporter, 3:3, 1998, np

Kidd, Colin, 'Race, Empire, and the Limits of Nineteenth-Century Scottish Nationhood', Historical Journal, 46:4, 2003, pp.873-892

King, Hazel, 'Problems of Police Administration in New South Wales, 1825-1851', JRAHS, 44:2, 1958, pp.49-70

Konishi, Shino, "“Wanton with Plenty”: Questioning Ethno-historical Constructions of Sexual Savagery in Aboriginal Societies, 1788-1803', Australian Historical Studies, 39:3, 2008, pp.356-372

Laidlaw, Zoe, 'Integrating Metropolitan, Colonial and Imperial Histories the Aborigines Select Committee of 1835-37', in Banivanua Mar and Evans (eds.), Writing Colonial Histories, pp.75-91

Lake, Marilyn, 'White Man's Country: the Trans-National History of a National Project', Australian Historical Studies, 34:122, 2003, pp.346-363 
Lester, Alan, and Dussart, Fae, 'Trajectories of Protection: Protectorates of Aborigines in Early 19th Century Australia and Aotearoa New Zealand', New Zealand Geographer, 64, 2008, pp.205-220

Lester, Alan, 'Colonial Networks, Australian Humanitarianism and the History Wars', Geographical Research, 44:3, 2006, pp.229-241

-, 'Colonial Settlers and the Metropole: Racial Discourse in the Early 19th-Century Cape Colony, Australia and New Zealand', Landscape Research, 27:1, 2002, pp.39-49

-, 'British Settler Discourse and the Circuits of Empire', History Workshop Journal, 54, 2002, pp.24-48

Lewthwaite, Gordon, 'The Population of Aotearoa: its Number and Distribution', New Zealand Geographer, 6:1, 1950, pp.35-52

Low, Peter, 'Pompallier and the Treaty: a New Discussion', NZJH, 24:2, 1990, pp.190-199

McCrae, George Gordon, 'The Early Settlement of the Eastern Shores of Port Phillip Bay, with a Note on the Aborigines of the Coast', VHM, 1:1, 1911, pp.17-26

McGrath, Ann, 'A National Story', in McGrath, Ann (ed.), Contested Ground, pp.1-54

-, 'Contested Ground: What is "Aboriginal History"?', in McGrath, Ann (ed.), Contested Ground, pp.359-397

-, "“Modern Stone-Age Slavery": Images of Aboriginal Labour and Sexuality', Labour History, 69, 1995, pp.30-51

-, 'The White Man's Looking Glass: Aboriginal-Colonial Gender Relations at Port Jackson', Australian Historical Studies, 24:95, 1990, pp.189-206 
McLisky, Claire, "“Due Observance of Justice, and the Protection of their Rights": Philanthropy, Humanitarianism and Moral Purpose in the Aborigines Protection Society circa 1837 and its Portrayal in Australian Historiography, 1883-2003', Limina, 11, 2005, pp.57-66

Mein Smith, Philippa, 'The Tasman World', in Byrnes (ed.), New Oxford History, pp.297-319

-, and Hempenstall, Peter, 'Australia and New Zealand: Turning Shared Pasts into a Shared History', History Compass, 1:1, 2003, pp.1-10

Mitchell, Jessie, "“The Gomorrah of the Southern Seas”: Population, Separation and Race in Early Colonial Queensland', History Australia, 6:3, 2009, pp.69.1-69.15

-, "“The galling yoke of slavery": Race and Separation in Colonial Port Phillip', Journal of Australian Studies, 33:2, 2009, pp.125-137

-, "“A City on a Hill": Aboriginal Missions and British Civilisation, 1830-1850', in Darian-Smith et al. (eds.), Exploring the British World, pp.223-236

-, "“Country Belonging to Me": Land and Labour on Aboriginal Mission and Protectorate Stations, 1830-1850', ERAS, 6, 2004, np

Mohr, Rowena, 'Neo-Colonialist Hagiography and the Making of an Australian Legend: Daisy Bates', Lateral, 2, 1999, np

Moneypenny, Maria, “"Going out and coming in”: Cooperation and Collaboration Between Aborigines and Europeans in Early Tasmania', Tasmanian Historical Studies, 5:1, 1995/1996, pp.64-75

Moon, Paul, and Fenton, Sabine, 'Bound into a Fateful Union: Henry Williams' Translation of the Treaty of Waitangi into Maori in February 1840', JPS, 111:1, 2002, pp.51-64 
Myscofski, Carole A., 'Imagining Cannibals: European Encounters with Native Brazilian Women', History of Religions, 47:2/3, 2007/2008, pp.142-155

Nance, Beverley, 'The Level of Violence: Europeans and Aborigines in Port Phillip, 1835-1850', Historical Studies, 19:77, 1981, pp.532-552

Nelson, H.N., 'The Missionaries and the Aborigines in the Port Phillip District', Historical Studies, 12:45, 1965, pp.57-67

Obeyesekere, Gananath, 'Narratives of the Self: Chevalier Peter Dillon's Fijian Cannibal Adventures', in Creed and Hoorn (eds.), Body Trade, pp.69-111

-, "'British Cannibals": Contemplation of an Event in the Death and Resurrection of James Cook, Explorer', Critical Inquiry, 18:4, 1992, pp.630-654

O'Callaghan, Thomas O., 'Police in Port Phillip and Victoria, 1836-1913', VHM, 12:4, 1928, pp.181-203

O'Connor, T.M., 'Edward Stone Parker: Pioneer and Protector', Heritage: a Journal of the Methodist Historical Society of Victoria, 15, 1963, pp.2-16

Orange, Claudia, 'The Covenant of Kohimarama: a Ratification of the Treaty of Waitangi', NZJH, 14:1, 1980, pp.61-82

Owens, J.M.R., 'New Zealand before Annexation', in Rice (ed.), Oxford History, pp.28-53

-, 'Religious Disputation at Whangaroa, 1823-7', JPS, 79:3, 1970, pp.288-304

-, 'Christianity and the Maoris to 1840 ', NZJH, 2:1, 1968, pp.18-40

Parr, C.J., 'A Missionary Library: Printed Attempts to Instruct the Maori, 1815-1845', JPS, 70:4, 1961, pp.429-450 
Parsonson, Ann, 'The Challenge to Mana Māori', in Rice (ed.), Oxford History, pp.167-198

-, 'The Pursuit of Mana', in Oliver and Williams (eds.), Oxford History, pp.140-167

-, 'The Expansion of a Competitive Society: a Study in NineteenthCentury Maori Social History', NZJH, 14:1, 1980, pp.45-60

Paterson, Lachy, 'Government, Church and Māori Responses to Mākutu (Sorcery) in New Zealand in the Nineteenth and Early Twentieth Centuries', Cultural and Social History, 8:2, 2011, pp.175-194

Penney, Jan, 'Murrundi Aborigines and Murray Squatters', VHM, 60:1, 1989, pp. $42-50$

Philips, David, 'Evangelicals, Aborigines and "Land Rights": a Critique of Henry Reynolds on the Select Committee on Aborigines', Australian Studies, 17:1, 2002, pp.147-165

Prentis, Malcolm D., 'Prelude to Dispossession? First Contacts between Aborigines and Europeans in the Northern Rivers Region of New South Wales, 1770-1840s', JRAHS, 70:1, 1984, pp.3-18

Reece, Bob, "“Killing with kindness": Daisy Bates and New Norcia', AH, 32, 2008, pp.128-145

-, "“You would have loved her for her lore": the Letters of Daisy Bates', Australian Aboriginal Studies, 1, 2007, pp.51-70

-, 'AP Elkin Interviewed about Daisy Bates', Australian Aboriginal Studies, 1, 2007, pp.131-137

-, 'Inventing Aborigines', AH, 11:1, 1987, pp.14-23 
Reynolds, Henry, 'Blainey and Aboriginal History', in Markus and Ricklefs (eds.), Surrender Australia?, pp.82-89

-, 'Aborigines and European Social Hierarchy', AH, 7:2, 1983, pp.124-133

-, 'The Land, the Explorers and the Aborigines', Historical Studies, 19:75, 1980, pp.213-226

-, 'The Other Side of the Frontier: Early Aboriginal Reactions to Pastoral Settlement in Queensland and Northern New South Wales', Historical Studies, 17:66, 1976, pp.50-63

-, 'Racial Thought in Early Colonial Australia', Australian Journal of Politics and History, 20:1, 1974, pp.45-53

Ritchie, Sam, "“No White man on the Station but myself": Whiteness as a Category of Analysis for the Reverend Francis Tuckfield', ACRAWSA e-journal, 5:1, 2009, pp.1-10

Ross, John O., 'Note: Busby and the Declaration of Independence', NZJH, 14:1, 1980, pp.83-89

Ross, Ruth, 'Te Tiriti o Waitangi: Texts and Translations', NZJH, 6:2, 1972, pp.129-157

Russell, Lynette, "'Dirty Domestics and Worse Cooks": Aboriginal Women's Agency and Domestic Frontiers, Southern Australia, 1800-1850', Frontiers: a Journal of Women Studies, 28:1-2, 2007, pp.18-46

-, "“Mere trifles and faint representations": the Representations of Savage Life Offered by Eliza Fraser', in McNiven et al. (eds.), Constructions of Colonialism, pp.51-62

Ryan, Lyndall, 'Settler Massacres on the Port Phillip Frontier, 1836-1851', Journal of Australian Studies, 34:3, 2010, pp.257-273 
-, 'Who Is the Fabricator?', in Manne (ed.), Whitewash, pp.230-257

Sadleir, J., 'The Early Days of the Victorian Police Force', VHM, 1:3, 1911, pp.73-79

Sahlins, Marshall, 'Artificially Maintained Controversies: Global Warming and Fijian Cannibalism', Anthropology Today, 19:3, 2003, pp.3-5

Sauer, R., 'Infanticide and Abortion in Nineteenth-Century Britain', Population Studies, 32:1, 1978, pp.81-93

Sayers, C.E., 'William Thomas', in Bride (ed.), Letters from Victorian Pioneers, pp.397-398

-, 'Henry Edward Pulteney Dana', in Bride (ed.), Letters from Victorian Pioneers, p.438

Schaffer, Kay, "“We are like Eliza”: Twentieth-Century Australian Responses to the Eliza Fraser Saga', in McNiven et al. (eds.), Constructions of Colonialism, pp.78-96

Shaw, A.G.L., 'Aborigines and Settlers in the Port Phillip District 1835-1850', La Trobe Journal, 61, 1998, pp.4-15

Shineberg, Dorothy, 'Guns and Men in Melanesia', JPH, 6, 1971, pp.61-82

Sinclair, Keith, 'Why New Zealanders are not Australians: New Zealand and the Australian Federal Movement, 1881-1901', in Sinclair (ed.), Tasman Relations, pp.90-103

-, 'Te Tikanga Pakeke: the Maori Anti-Land-Selling Movement in Taranaki, 1849-59', in Munz (ed.), Feel of Truth, pp.77-92

Smithyman, Kendrick, 'Making History: John White and S. Percy Smith at Work', JPS, 88:4, 1979, pp.375-413 
Sorrenson, M.P.K., ‘[Review of] Hill, Edward: There Was a Taranaki Land League', JPS, 80:1, 1971, pp.136-137

Soutar, Monty, 'Kūpapa: a Shift in Meaning', He Pukenga Kōrero: a Journal of Maori Studies, 6:2, 2001, pp.35-39

Standfield, Rachel, 'The Parramatta Maori Seminary and the Education of Indigenous Peoples in Early Colonial New South Wales', History of Education Review, 41:2, 2012, pp.119-128

-, 'Violence and the Intimacy of Imperial Ethnography: the Endeavour in the Pacific', in Ballantyne and Burton (eds.), Moving Subjects, pp.3148

Stannard, David E., 'Recounting the Fables of Savagery: Native Infanticide and the Functions of Political Myth', Journal of American Studies, 25:3, 1991, pp.381-417

Stanner, W.E.H., 'Aboriginal Territorial Organization: Estate, Range, Domain and Regime', Oceania, 36:1, 1965, pp.1-26

Tau, Te Maire, '[Review of] Paul Moon, This Horrid Practice', Te Pouhere Korero, 3, 2009, pp.119-124

Thomas, Celia, 'Native Police', Police Life, November 1983, pp.10-14

Thompson, Christina A., 'A Dangerous People Whose Only Occupation is War: Maori and Pakeha in 19th-Century New Zealand', JPH, 32:1, 1997, pp.109-119

Twomey, Christina, 'Vagrancy, Indolence and Ignorance: Race, Class and the Idea of Civilization in the Era of Aboriginal "Protection", Port Phillip 1835-49, in Banivanua Mar and Evans (eds.), Writing Colonial Histories, pp.93-113

Urlich, D.U., 'Migrations of the North Island Maoris 1800-1840: a Systems View of Migration', New Zealand Geographer, 28:1, 1972, pp.23-35 
-, 'The Introduction and Diffusion of Firearms in New Zealand 18001840', JPS, 79:4, 1970, pp.399-410

Vasey, G.B., 'John Walpole Willis, the First Resident Judge of Port Phillip', VHM, 1:2, 1911, pp.36-49

Vayda, A.P., 'Maoris and Muskets in New Zealand: Disruption of a War System', Political Science Quarterly, 85:4, 1970, pp.560-584

-, 'Maori Conquests in Relation to the New Zealand Environment', JPS, 65:3, 1956, pp.204-211

Wake, C.H., 'George Clarke and the Government of the Maoris: 1840-45', Historical Studies, Australia and New Zealand, 10:39, 1962, pp.339-356

Walsh, Gerald, 'The Military and the Development of the Australian Colonies, 1788-1888', in McKernan and Browne (eds.), Australia: Two Centuries of War $\mathcal{E}$ Peace, pp.43-64

Ward, Alan, 'Commentary: the Treaty and the Purchase of Maori Land', NZJH, 22:2, 1988, pp.169-174

-, 'Law and Law-enforcement on the New Zealand Frontier, 1840-1893', NZJH, 5:2, 1971, pp.128-149

-, 'The Origins of the Anglo-Maori Wars: a Reconsideration', NZJH, 1:2, 1967, pp.148-170

Wards, Ian, 'The Generalship of Governor Grey, 1846-52', in Munz (ed.), Feel of Truth, pp.93-110

Wey-Gómez, Nicholás, 'A Poetics of Dismemberment: the Book of Job and the Cannibals of Cariay in Columbus's Account of the Fourth Voyage', Colonial Latin American Review, 16:1, 2007, pp.109-123 
Williams, Glyndwr, “"Far More Happier than We Europeans”: Reactions to the Australian Aborigines on Cook's Voyage', Historical Studies, 19:77, 1981, pp.499-512

Windschuttle, Keith, 'The Myths of Frontier Massacres in Australia', 3 parts, Quadrant, 44:10-12, 2000, pp.8-20, 17-23, \& 6-20

Woolmington, Jean, "“Writing on the Sand": the First Missions to Aborigines in Eastern Australia', in Swain and Rose (eds.), Aboriginal Australians and Christian Missions, pp.77-92

-, 'The Civilisation/Christianisation Debate and the Australian Aborigines', $A H, 10: 2,1986$, pp.90-98

-, 'Early Christian Missions to the Australian Aborigines', VHM, 26, 1974, pp.1-7 


\section{Books}

Adams, Peter, Fatal Necessity: British Intervention in New Zealand, 1830-1847, Auckland:1977

Anderson, David M., and Killingray, David (eds.), Policing the Empire: Government, Authority and Control, 1830-1940, Manchester:1991

Arens, W., The Man-Eating Myth: Anthropology \& Anthropophagy, Oxford:1979

Arkley, Lindsey, The Hated Protector: the Story of Charles Wightman Sievwright, Protector of Aborigines 1839-42, Melbourne:2000

Australian Dictionary of Biography, online edition

Bagnall, A.G., and Petersen, G.C., William Colenso: Printer, Missionary, Botanist, Explorer, Politician, His Life and Journeys, Wellington:1948

Ballantyne, Tony, and Burton, Antoinette (eds.), Moving Subjects: Gender, Mobility, and Intimacy in an Age of Global Empire, Chicago:2009

Ballantyne, Tony, Webs of Empire: Locating New Zealand's Colonial Past, Wellington:2012

-, Orientalism and Race: Aryanism in the British Empire, New York:2002

Ballara, Angela, Taua: 'Musket Wars', 'Land Wars' or Tikanga? Warfare in Māori Society in the Early Nineteenth Century, Auckland:2003

-, Iwi: the Dynamics of Māori Tribal Organisation from c.1769 to c.1945, Wellington:1998

Banivanua Mar, Tracey, and Evans, Julie (eds.), Writing Colonial Histories: Comparative Perspectives, Melbourne:2002 
Barthorp, Michael, To Face the Daring Maoris: Soldiers' Impressions of the First Maori War, 1845-47, London:1979

Bebbington, D.W., Evangelicalism in Modern Britain: a History from the 1730s to the 1980s, London:1989

Belich, James, Replenishing the Earth: the Settler Revolution and the Rise of the Anglo-World, 1783-1939, Oxford:2009

-, Paradise Reforged: a History of the New Zealanders, from the 1880s to the Year 2000, Auckland:2001

-, Making Peoples: a History of the New Zealanders, from Polynesian Settlement to the End of the Nineteenth Century, Auckland:1996

-, 'I Shall Not Die': Titokowaru's War, New Zealand, 1868-9, Wellington:1989

-, The New Zealand Wars and the Victorian Interpretation of Racial Conflict [1986], Auckland:1998

Berndt, Ronald M., and Berndt, Catherine H., The World of the First Australians, Aboriginal Traditional Life: Past and Present [1964], fifth edition, Canberra:1988

Binney, Judith, Encircled Lands: Te Urewera, 1820-1921, Wellington:2009

-, Redemption Songs: a Life of Te Kooti Arikirangi Te Turuki, Auckland:1995

-, The Legacy of Guilt: a Life of Thomas Kendall [1968], Wellington:2005

Blacket, John, Missionary Triumphs Among the Settlers in Australia and the Savages of the South Seas, London:1914 
Blainey, Geoffrey, Triumph of the Nomads: a History of Ancient Australia [1975], revised edition Sydney:1983

Blake, Leslie, Captain Dana and the Native Police, Geelong:1982

Bonwick, James, The Last of the Tasmanians; or, the Black War of Van Diemen's Land, London:1870

-, The Wild White Man and the Blacks of Victoria [1856], second edition Melbourne:1863

-, William Buckley, the Wild White Man, and his Port Phillip Black Friends, Melbourne:1856

Boys, Robert Douglass, First Years at Port Phillip: Preceded by a Summary of Historical Events from 1768, Melbourne:1935

Broome, Richard, Aboriginal Victorians: a History Since 1800, Sydney:2005

-, Aboriginal Australians: Black Responses to White Dominance, 1788-1994 [1982], second edition Sydney:1994

Buick, T. Lindsay, New Zealand's First War, or the Rebellion of Hone Heke [1926], Christchurch:1976

-, The Treaty of Waitangi: How New Zealand Became a British Colony [1914], New Plymouth:1936

Byrnes, Giselle (ed.), The New Oxford History of New Zealand, Melbourne:2009

Cannon, Michael, Who Killed the Koories? The True, Terrible Story of Australia's Founding Years, Melbourne:1990

Carleton, Hugh, The Life of Henry Williams: Archdeacon of Waimate, 2 vols., Auckland:1874 \& 1877 
Chisholm, Jocelyn, Brind of the Bay of Islands: Some Readings and Notes of Thirty Years in the Life of a Whaling Captain, Wellington:1979

Christie, M.F., Aborigines in Colonial Victoria 1835-86, Sydney:1979

Clark, C.M.H., A History of Australia, 6 vols., Melbourne:1962-1987

Clark, Ian D., and Heydon, Toby, A Bend in the Yarra: a History of the Merri Creek Protectorate Station and Merri Creek Aboriginal School 1841-1851, Canberra:2004

Clendinnen, Inga, Dancing with Strangers, Melbourne:2003

Cole, Anna, Haskins, Victoria, and Paisley, Fiona (eds.), Uncommon Ground: White Women in Aboriginal History, Canberra:2005

Connor, John, The Australian Frontier Wars, 1788-1838, Sydney:2002

Copland, Mark, Richards, Jonathan, and Walker, Andrew, One Hour More Daylight: a Historical Overview of Aboriginal Dispossession in Southern and Southwest Queensland, Toowoomba:2006

Corris, Peter, Aborigines and Europeans in Western Victoria, Canberra:1968

Cowan, James, Sir Donald Maclean: the Story of a New Zealand Statesman, Dunedin:1940

-, New Zealand Wars: a History of the Maori Campaigns of the Pioneering Period, 2 vols., Wellington:1922-1923

Creed, Barbara, and Hoorn, Jeanette (eds.), Body Trade: Captivity, Cannibalism and Colonialism in the Pacific, New York:2001

Critchett, Jan, A 'Distant Field of Murder': Western District Frontiers 1834-1848, Melbourne:1990 
Crosby, Ron, The Musket Wars: a History of Inter-Iwi Conflict, 1806-45, Auckland:1999

Dalton, B.J., War and Politics in New Zealand, 1855-1870, Sydney:1967

Damousi, Joy, and Ellinghaus, Katherine (eds.), Citizenship, Women and Social Justice: International Historical Perspectives, Melbourne:1999

Darian-Smith, Kate, Grimshaw, Patricia, Kiera, Lindsey, and Macintyre, Stuart (eds.), Exploring the British World: Identity, Cultural Production, Institutions, Melbourne:2004

Darian-Smith, Kate, Poignant, Roslyn, and Schaffer, Kay (eds.), Captured Lives: Australian Captivity Narratives, London:1993

Dictionary of New Zealand Biography, online edition

Dyer, Colin, The French Explorers and the Aboriginal Australians, 1772-1839, Brisbane:2005

Edmond, Rod, Representing the South Pacific: Colonial Discourse from Cook to Gauguin, Cambridge:1997

Ellender, Isabel, and Christiansen, Peter, People of the Merri Merri: the Wurundjeri in Colonial Days, Melbourne:2001

Evans, Raymond, A History of Queensland, Cambridge:2007

Evans, Roger, Truth and Obedience: the Life and Letters of George Clarke 1798-1875, Missionary, Protector of Aborigines, and Defender of the Treaty of Waitangi, Kerikeri:2004

Fargher, Ray, The Best Man Who Ever Served the Crown? A Life of Donald McLean, Wellington:2007

Favenc, Ernest, The History of Australian Exploration, from 1788 to 1888 [1888], Sydney:1983 
Fels, Marie Hansen, 'I Succeeded Once': the Aboriginal Protectorate on the Mornington Peninsula, 1839-1840, Canberra:2011

-, Good Men and True: the Aboriginal Police of the Port Phillip District, 1837-1853, Melbourne:1988

Foxcroft, Edmund J.B., Australian Native Policy: Its History, Especially in Victoria, Melbourne:1941

Gibson, Tom, The Maori Wars: the British Army in New Zealand, 1840-1872, London:1974

Godfrey, Barry, and Dunstall, Graeme (eds.), Crime and Empire, 1840-1940: Criminal Justice in Local and Global Context, Devon:2005

Gribbin, John, and Gribbin, Mary, FitzRoy: the Remarkable Story of Darwin's Captain and the Invention of the Weather Forecast, London:2003

Hall, Richard, Black Armband Days: Truth from the Dark Side of Australia's Past, Sydney:1998

Hanson, F. Allan, and Hanson, Louise, Counterpoint in Maori Culture, London:1983

Hanson, Pauline, The Truth: on Asian Immigration, the Aboriginal Question, the Gun Debate and the Future of Australia, Brisbane:1997

Harris, John, One Blood: 200 Years of Aboriginal Encounter with Christianity: a Story of Hope [1990], second edition Sydney:1994

Hickford, Mark, Lords of the Land: Indigenous Property Rights and the Jurisprudence of Empire, Oxford:2011

Hill, Edward, There Was a Taranaki Land League, Wellington:1969 
Hill, Richard S., Introducing Policing to the Rangatiratanga Discourse: an Historical Overview of the Role of Maori Police Personnel, Wellington:2003

-, The Iron Hand in the Velvet Glove: the Modernisation of Policing in New Zealand, 1886-1917, Wellington:1995

-, The Colonial Frontier Tamed: New Zealand Policing in Transition, 1867-1886, Wellington:1989

-, Policing the Colonial Frontier: the Theory and Practice of Coercive Social and Racial Control in New Zealand, 1767-1867, 2 parts, Wellington:1986

Hogg, Gary, Cannibalism and Human Sacrifice [1958], Stroud, Gloucestershire:2007

Horton, David (ed.), The Encyclopaedia of Aboriginal Australia: Aboriginal and Torres Strait Islander History, Society and Culture, 2 vols., Canberra:1994

Howe, K.R., Race Relations, Australia and New Zealand: a Comparative Survey 1770's-1970's, Wellington:1977

Hughes, Robert, The Fatal Shore: the Epic of Australia's Founding, New York:1987

Johnston, Anna, The Paper War: Morality, Print Culture, and Power in Colonial New South Wales, Perth:2011

Kidd, Colin, The Forging of Races: Race and Scripture in the Protestant Atlantic World, 1600-2000, Cambridge:2006

King, Michael, The Penguin History of New Zealand, Auckland:2003

Konishi, Shino, The Aboriginal Male in the Enlightenment World, London:2012

Laidlaw, Zoë, Colonial Connections, 1815-45: Patronage the Information Revolution and Colonial Government, Manchester:2005 
Le Griffon, Heather, Campfires at the Cross: an Account of the Bunting Dale Aboriginal Mission at Birregurra, near Colac, Victoria 1839-1851, Melbourne:2006

McGibbon, Ian (ed.), The Oxford Companion to New Zealand Military History, Auckland:2000

McGrath, Ann (ed.), Contested Ground: Australian Aborigines under the British Crown, Sydney:1995

McGregor, Russell, Imagined Destinies: Aboriginal Australians and the Doomed Race Theory, 1880-1939, Melbourne:1997

McKenzie, D.F., Oral Culture, Literacy \& Print in Early New Zealand: the Treaty of Waitangi, Wellington:1985

McKernan, M. and Browne, M. (eds.), Australia: Two Centuries of War E Peace, Canberra:1988

McLintock, A.H., Crown Colony Government in New Zealand, Wellington:1958

McNiven, Ian J., Russell, Lynette, and Schaffer, Kay (eds.), Constructions of Colonialism: Perspectives on Eliza Fraser's Shipwreck, London:1998

Macmorran, Barbara, Octavius Hadfield, Wellington:1969

Manne, Robert (ed.), Whitewash: on Keith Windschuttle's Fabrication of Aboriginal History, Melbourne:2003

Markus, Andrew, and Ricklefs, M.C. (eds.), Surrender Australia? Essays in the Study and Uses of History: Geoffrey Blainey and Asian Immigration, Sydney:1985

Marshall, P.J., and Williams, Glyndwr, The Great Map of Mankind: British Perceptions of the World in the Age of Enlightenment, London:1982 
Mein Smith, Philippa, Hempenstall, Peter, and Goldfinch, Shaun, Remaking the Tasman World, Christchurch:2009

Miller, S.I., Police in Victoria 1836-1980, Melbourne:1980

Moon, Paul, This Horrid Practice: the Myth and Reality of Traditional Maori Cannibalism, Auckland:2008

Morton, Harry, The Whale's Wake, Dunedin:1982

Mulvaney, D.J., and Golson, J. (eds.), Aboriginal Man and Environment in Australia, Canberra:1971

Munz, Peter (ed.), The Feel of Truth: Essays in New Zealand and Pacific History, Wellington:1969

Nettelbeck, Amanda, and Foster, Robert, In the Name of the Law: William Willshire and the Policing of the Australian Frontier, Adelaide:2007

Newman, Keith, Bible E Treaty: Missionaries among the Māori-a New Perspective, Auckland:2010

Obeyesekere, Gananath, Cannibal Talk: the Man-Eating Myth and Human Sacrifice in the South Seas, Berkeley:2005

Oliver, Douglas L., Ancient Tahitian Society, 3 vols., Honolulu:1974

Oliver, W.H., and Williams, B.R. (eds.), The Oxford History of New Zealand, Oxford:1981

O'Malley, Vincent, The Meeting Place: Māori and Pākehā Encounters, 1642-1840, Auckland:2012

Orange, Claudia, The Treaty of Waitangi, Wellington:1987

O'Sullivan, John, Mounted Police of Victoria E Tasmania, Sydney:1980 
Owens, J.M.R., The Mediator: a Life of Richard Taylor, 1805-1873,

Wellington:2004

Pierson, Ruth Roach, and Chaudhuri, Nupur (eds.), Nation, Empire, Colony: Historicizing Gender and Race, Bloomington, Indiana:1998

Pool, Ian, Te Iwi Maori: a New Zealand Population Past, Present E Projected, Auckland:1991

Presland, Gary, First People: the Eastern Kulin of Melbourne, Port Phillip $\mathcal{E}$ Central Victoria, Melbourne:2010

-, For God's Sake Send in the Trackers: a History of Queensland Trackers and Victoria Police, Melbourne:1998

Pybus, Cassandra, Community of Thieves, Melbourne:1991

Rae-Ellis, Vivienne, Black Robinson: Protector of Aborigines, Melbourne:1988

Reece, Bob, Daisy Bates: Grand Dame of the Desert, Canberra:2007

-, Aborigines and Colonists: Aborigines and Colonial Society in New South Wales in the 1830s and 1840s, Sydney:1974

Reynolds, Henry, Fate of a Free People: a Radical Re-examination of the Tasmanian Wars, Melbourne:1995

-, With the White People: the Crucial Role of Aborigines in the Exploration and Development of Australia, Melbourne:1990

-, The Other Side of the Frontier: Aboriginal Resistance to the European Invasion of Australia [1981], Melbourne:1982

Rice, Geoffrey W. (ed.), The Oxford History of New Zealand: Second Edition, Auckland:1992 
Richards, Jonathan, The Secret War: a True History of Queensland's Native Police, Brisbane:2008

Rogers, Lawrence M., Te Wiremu: a Biography of Henry Williams [1973], Christchurch:1998

Rusden, G.W., History of New Zealand, 3 vols., London:1883

Russell, Lynette, Savage Imaginings: Historical and Contemporary Constructions of Australian Aboriginalities, Melbourne:2001

Rutherford, James, Hone Heke's Rebellion: an Episode in the Establishment of British Rule inNew Zealand, Auckland:1947

Ryan, Lyndall, Tasmanian Aborigines: a History Since 1803, Sydney:2012 -, The Aboriginal Tasmanians [1981], second edition Sydney:1996

Sadleir, John, Recollections of a Victorian Police Officer [1913], Melbourne:1973

Salesa, Damon Ieremia, Racial Crossings: Race, Intermarriage, and the Victorian British Empire, Oxford:2011

Salmond, Anne, Aphrodite's Island: the European Discovery of Tahiti, Auckland:2009

-, The Trial of the Cannibal Dog: Captain Cook in the South Seas, London:2003

-, Between Worlds: Early Exchanges Between Maori and Europeans, 1773-1815, Auckland:1997

-, Two Worlds: First Meetings Between Maori and Europeans, 1642-1772, Auckland:1991

Schaffer, Kay, In the Wake of First Contact: the Eliza Fraser Stories, Cambridge:1995 
Sharp, Andrew, and McHugh, Paul (eds.), Histories of Power and Loss: Uses of the Past-a New Zealand Commentary, Wellington:2001

Shaw, A.G.L, A History of the Port Phillip District: Victoria Before Separation [1996], Melbourne:2003

Sinclair, Keith (ed.), Tasman Relations: New Zealand and Australia, 1788-1988, Auckland:1987

-, A History of New Zealand [1959], revised edition Auckland:1988

-, The Origins of the Maori Wars [1957], revised edition Auckland:1961

-, The Maori Land League: an Examination into the Source of a New Zealand Myth, Auckland:1950

Sissons, Jeffrey, Wi Hongi, Wiremu, and Hohepa, Pat, Ngā Pūriri o Taiamai: a Political History of Ngā Puhi in the Inland Bay of Islands [1987], second edition Auckland:2001

Smith, Bernard, Imagining the Pacific in the Wake of the Cook Voyages, Melbourne:1992

-, European Vision and the South Pacific [1960], second edition Sydney:1989

Smith, S. Percy, History and Traditions of the Maoris of the West Coast North Island of New Zealand Prior to 1840, New Plymouth:1910

-, Maori Wars of the Nineteenth Century: the Struggle of the Northern against the Southern Tribes prior to the Colonization of New Zealand in 1840, Christchurch:1910

Smith, Vanessa, Intimate Strangers: Friendship, Exchange and Pacific Encounters, Cambridge: 2010 
Standfield, Rachel, Race and Identity in the Tasman World, 1769-1840, London:2012

Stanner, W.E.H., White Man Got No Dreaming: Essays, 1938-1973, Canberra:1979

Swain, Tony, and Rose, Deborah Bird (eds.), Aboriginal Australians and Christian Missions: Ethnographic and Historical Studies, Adelaide:1988

Thomas, Nicholas, Discoveries: the Voyages of Captain Cook, London:2003

Urlich Cloher, Dorothy, Hongi Hika: Warrior Chief, Auckland:2003

Vayda, A.P., Maori Warfare, Wellington:1960

Walker, Ranginui, Ka Whawhai Tonu Matou: Struggle Without End [1990], second edition Auckland:2004

Wanhalla, Angela, In/visible Sight: the Mixed-Descent Families of Southern New Zealand, Wellington:2009

Ward, Alan, A Show of Justice: Racial 'Amalgamation' in Nineteenth Century New Zealand, Canberra:1974

Wards, Ian, The Shadow of the Land: a Study of British Policy and Racial Conflict in New Zealand, 1832-1852, Wellington:1968

Wells, Benjamin, The History of Taranaki: a Standard Work on the History of the Province, New Plymouth:1878

White, Richard, The Middle Ground: Indians, Empires, and Republics in the Great Lakes Region, 1650-1815, Cambridge:1991

Williams, Glyndwr (ed.), Captain Cook: Explorations and Reassessments, Woodbridge, Suffolk:2004

Wilson, Ormond, Kororareka E Other Essays, Dunedin:1990 
-, From Hongi Hika to Hone Heke: a Quarter Century of Upheaval, Dunedin:1985

Windschuttle, Keith, The Fabrication of Aboriginal History, Volume Three: the Stolen Generations, 1881-2008, Sydney:2009

-, The Fabrication of Aboriginal History, Volume One: Van Diemen's Land, 1803-1847, Sydney:2002

Wright, Harrison M., New Zealand, 1769-1840: Early Years of Western Contact, Cambridge, Massachusetts:1959

Yarwood, A.T., and Knowling, M.J., Race Relations in Australia: a History, Sydney:1982

Yarwood, A.T., Samuel Marsden: the Great Survivor, Melbourne:1977 


\section{Theses}

Ballara, Angela, 'Warfare and Government in Ngapuhi Tribal Society, 1814-1833: Institutions of Authority and the Function of Warfare in the Period of Early Settlement 1814-1833, in the Bay of Islands and Related Territories', MA thesis, University of Auckland:1973

Bentley, Trevor, 'Tribal Guns, Tribal Gunners: a Study of Acculturation by Maori of European Military Technology during the New Zealand Inter-Tribal Musket Wars', MA thesis, University of Waikato:1997

Blaskett, Beverley A., 'The Aboriginal Response to White Settlement in the Port Phillip District, 1835-1850', MA thesis, University of Melbourne:1979

Crawford, I.M., 'William Thomas and the Port Phillip Protectorate, 1838-1849', MA thesis, University of Melbourne:1966

Gibbons, Peter D., 'The Protectorate of Aborigines, 1840-1846', MA thesis, Victoria University of Wellington:1963

Kerbel, Ivan P., 'Notorious: a History of Kororāreka and the New Zealand Frontier, c.1800-1850', MLitt thesis, University of Auckland:1998

Mitchell, Jessie, 'Flesh, Dreams and Spirit: Life on Aboriginal Mission Stations, 1825-1850, a History of Cross-Cultural Connections', PhD thesis, Australian National University:2005

Ritchie, S.G.G., '“[T]he sound of the bell amidst the wilds”: Evangelical Perceptions of Northern Aotearoa/New Zealand Māori and the Aboriginal Peoples of Port Phillip, Australia, c.1820s-1840s', MA thesis, Victoria University of Wellington:2009

Shroff, G.W., 'George Clarke and the New Zealand Mission, 1824-1850', PhD thesis, University of Auckland:1967 
Soutar, Monty, 'Ngāti Porou Leadership - Rāpata Wahawaha and the Politics of Conflict', PhD thesis, Massey University:2000

Standfield, Rachel, 'Warriors and Wanderers: Making Race in the Tasman World, 1769-1840', PhD thesis, University of Otago:2008

Turner, Philip, 'The Politics of Neutrality: the Catholic Mission and the Maori 1838-1870', MA thesis, University of Auckland:1968

Yeo, Carol, 'Ideals, Policy \& Practice: the New Zealand Protectorate of Aborigines 1840-1846', MA thesis, Massey University:2001 